UNIVERSIDADE DE BRASÍLIA

FACULDADE DE TECNOLOGIA DEPARTAMENTO DE ENGENHARIA CIVIL E AMBIENTAL

\title{
PROPOSTA DE FERRAMENTA DE ANÁLISE MULTICRITÉRIO DE APOIO À GESTÃO MUNICIPAL DA MOBILIDADE URBANA
}

LEONARDO NOGUEIRA DE MORAES

ORIENTADORA: ANA CLAUDIA FARRANHA

DISSERTAÇÃO DE MESTRADO EM TRANSPORTES PUBLICAÇÃO; T.DM-002/2017 


\section{UNIVERSIDADE DE BRASÍLIA}

FACULDADE DE TECNOLOGIA

DEPARTAMENTO DE ENGENHARIA CIVIL E AMBIENTAL

\section{PROPOSTA DE FERRAMENTA DE ANÁLISE MULTICRITÉRIO DE APOIO À GESTÃO MUNICIPAL DA MOBILIDADE URBANA}

\section{LEONARDO NOGUEIRA DE MORAES}

DISSERTAÇÃO DE MESTRADO SUBMETIDA AO DEPARTAMENTO DE ENGENHARIA CIVIL E AMBIENTAL DA FACULDADE DE TECNOLOGIA DA UNIVERSIDADE DE BRASÍLIA COMO PARTE DOS REQUISITOS NECESSÁRIOS PARA A OBTENÇÃO DO GRAU DE MESTRE EM TRANSPORTES.

APROVADA POR:

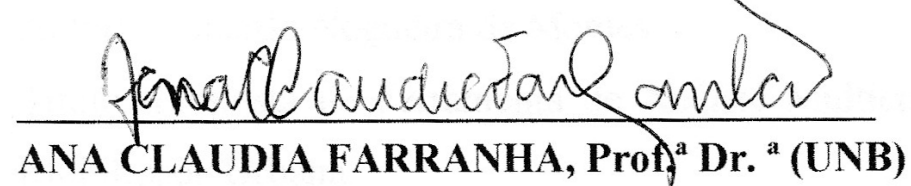

(ORIENTADORA)

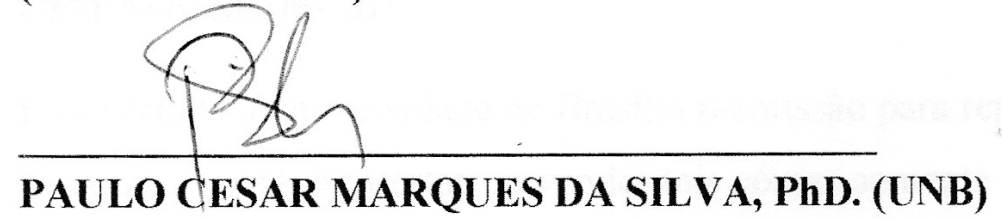

(EXAMINADOR INTERNO)

\section{Enika cistine knib}

ERIKA CRISTINE KNEIB, Prof. ${ }^{a}$ Dr. ${ }^{a}$ (UFG)

(EXAMINADORA EXTERNA) 


\section{FICHA CATALOGRÁFICA}

MORAES, LEONARDO NOGUEIRA DE.

Proposta de Ferramenta de Análise Multicritério de Apoio à Gestão Municipal da Mobilidade Urbana [Distrito Federal] 2017.

xiv, 143p., 2010 x 297 mm (ENC/FT/UnB, Mestre, Transportes, 2017)

Dissertação de Mestrado - Universidade de Brasília, Faculdade de Tecnologia.

Departamento de Engenharia Civil e Ambiental.

1. Mobilidade Urbana

3. Análise Multicritério

I. ENC/FT/UnB
2. Gestão Estratégica

4. Município

II. Título (série)

\section{REFERÊNCIA BIBLIOGRÁFICA}

MORAES, L. N. (2017). Proposta de Ferramenta de Análise Multicritério de Apoio à Gestão Municipal da Mobilidade Urbana.

Dissertação de Mestrado em Transportes, Publicação T.DM-002/2017, janeiro de 2017. Departamento de Engenharia Civil e Ambiental, Universidade de Brasília, Brasília, DF, 143 pág.

\section{CESSÃO DE DIREITOS}

Autor: Leonardo Nogueira de Moraes

Título: Proposta de Ferramenta de Análise Multicritério de Apoio à Gestão Municipal da Mobilidade Urbana.

Grau/Ano: Mestre/2017

É concedida a Universidade de Brasília permissão para reproduzir cópias desta dissertação de mestrado e para emprestar ou vender tais cópias somente para fins acadêmicos-científicos. $\mathrm{O}$ autor reserva outros direitos de publicação e nenhuma parte desta dissertação de mestrado pode ser reproduzida sem a autorização por escrito do autor.

Leonardo Nogueira de Moraes

QE 32, Conjunto $\mathrm{P}, \mathrm{n}^{\circ} 08$ - Guará II.

CEP: 71065-161 Brasília - DF

leonardom333@gmail.com 


\section{DEDICATÓRIA}

Dedico aos meus queridos pais,

filhos, esposa e irmãos, que estão comigo em todos os momentos da vida. 


\section{AGRADECIMENTOS}

Em primeiro lugar, agradeço a Deus, pois sem ele nada é possível. Além de me dar a luz de que preciso para galgar e superar os obstáculos da vida, também tem me dado força para superar a perda de entes queridos, como meu pai, avôs e tios que já partiram deste plano de vida.

À minha avó Edite, pois todas as minhas virtudes são copiadas dela, uma pessoa extraordinária, leve, amorosa, preocupada com o próximo, única no mundo.

Ao meu falecido pai, Felix de Assis, pelo relacionamento amoroso e de amizade que teve em vida comigo.

À minha mãe Lenir, lutadora e protetora dos filhos e netos, que me assiste e me acompanha nos momentos da vida.

À minha esposa Danielle, que está ao meu lado todos os dias, num relacionamento de amor e respeito mútuo, em todos os momentos de nossas vidas.

Aos meus filhos, Matheus, Laura e Maria Luísa, que são a razão da minha vida.

Ao meu melhor amigo e irmão Floriano, pelo tempo doado às nossas conversas sérias e às descontraídas.

À minha família em geral, que mesmo a distância torce sempre por mim.

À minha querida orientadora Ana Claudia Farranha, pelos ensinamentos e pelo carinho no processo de construção desse trabalho.

Aos professores do programa de pós-graduação em transportes da UNB, em especial ao professor Paulo César, que é um espelho de conhecimento e de serenidade para mim. Minha motivação para fazer o mestrado partiu da leitura de um artigo de sua autoria.

E, por fim, agradeço a todos que contribuíram para a realização deste trabalho. 


\section{RESUMO}

A dissertação apresenta uma proposta de ferramenta capaz de avaliar a aplicação da Lei 12.587/2012 à luz da gestão estratégica exercida no município. O objetivo é desenvolver um método que avalie a relação entre o processo político de decisão em ambiente estratégico e o processo de execução em ambiente de gestão, necessários para o exercício da Política Nacional de Mobilidade Urbana localmente. Na ótica geral, a metodologia partiu da análise de direcionadores estratégicos da Lei de Mobilidade, gerando instrumentos alçados no trabalho como Critérios de Avaliação, que carregam importantes pilares da Lei. A aplicação de critérios subjetivos empregados na metodologia está formalmente amparada pela ferramenta de análise multicritério Macbeth, que atua no sentido de reduzir as subjetividades do processo de avaliação. Na ótica mais específica, a metodologia foi aplicada em caso concreto no município de Palmas, capital do estado do Tocantins, com a finalidade de medir a sinergia entre a Política de Mobilidade Urbana do Município por meio do engajamento entre a estrutura de decisão e a estrutura de execução, definindo um índice comparativo de avaliação. Esse índice permite enquadrar o município no espaço da política pública de mobilidade.

Palavras-chaves: Mobilidade Urbana, Gestão Estratégica, Análise Multicritério, Município. 


\begin{abstract}
This dissertation presents a proposal of a tool suitable for evaluation of the application of legislation 12,587 / 2012 (Mobility bill) in light of the strategic management applied in the Municipality. The goal is to develop a method to assess the relationship between the political decision process in the strategic level and the execution process in the management level, both necessary for the enforcement of the National Urban Mobility Policy at the local level. In general, the methodology was based on the analysis of strategic drivers of the Mobility bill, providing instruments created as Evaluation Criteria, which carry important concepts of the Bill. The application of subjective criteria used in the methodology is formally supported by the multicriteria analysis tool Macbeth, which is focused in reduction of the subjectivity factor of the evaluation process. In a more specific perspective, the methodology was applied in a real case in the Municipality of Palmas, capital of the State of Tocantins. In order to measure the synergy between the Urban Mobility Policy of the Municipality through the engagement between the decision structure and the execution structure, thus defining a comparative evaluation index. This index enables to place the Municipality within the scope of public mobility policy.
\end{abstract}

Key words: Urban Mobility, Strategic Management, Multicriteria Analysis, Municipality. 


\section{SUMÁRIO}

1 INTRODUÇÃO

1.1 APRESENTAÇÃO 15

1.2 DELIMITAÇÃO DO PROBLEMA 16

$\begin{array}{ll}1.3 \text { HIPÓTESES } & 17\end{array}$

$\begin{array}{ll}1.4 \text { OBJETIVOS } & 18\end{array}$

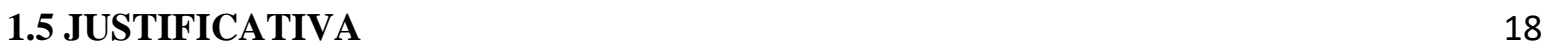

1.6 ESTRUTURA DA DISSERTAÇÃO 22

2 MUNICÍPIO E SUAS INTER-RELAÇÕES COM A POLÍTICA DE MOBILIDADE $\begin{array}{ll}\text { URBANA } & 23\end{array}$

2.1 TOMADA DE DECISÃO NO ÂMBITO DA POLÍTICA PÚBLICA 23

2.2 COMPETÊNCIAS DO MUNICÍPIO 27

2.3 ESTATUTO DAS CIDADES 30

2.4 LEI DE MOBILIDADE URBANA (LEI 12.587/2012) 34

2.5 PARTICIPAÇÃO SOCIAL 43

2.6 TÓPICOS CONCLUSIVOS 46

3 GESTÃO MUNICIPAL DA MOBILIDADE 48

3.1 GESTÃO PÚBLICA

3.2 GESTÃO DE PROJETOS E A TEORIA DOS STAKEHOLDERS

3.3 GESTÃO ESTRATÉGICA

3.4 TÓPICOS CONCLUSIVOS 64

4 MÉTODO MULTICRITÉRIO DE AVALIÇÃO DA POLÍTICA DE MOBILIDADE $\begin{array}{ll}\text { URBANA } & 65\end{array}$

4.1 CONSIDERAÇÕES INICIAIS 65

4.2 ANÁLISE MULTICRITÉRIO DE APOIO A DECISÃO MACBETH 66

4.3 MATRIZ DE AVALIAÇÃO - CRITÉRIOS DE AVALIAÇÃO 72

4.4 MATRIZ DE PREFERÊNCIA

4.5 DEFINIÇÃO DAS OPÇÕES COMPARÁVEIS

4.6 ESTRUTURAÇÃO DA ÁRVORE DE PONTOS DE VISTA

4.7 VALIDAÇÃO DOS JULGAMENTOS

4.8 ORDENAÇÕES CONFORME AVALIÇÃO DO DECISOR 85

4.9 INSERÇÃO DE DADOS DAS AVALIAÇÕES QUALITATIVAS 86

4.10 OBTENÇÃO DE RESULTADOS E GRÁFICOS 87 
5 APLICAÇÃO DO MÉTODO MULTICRITÉRIO DE AVALIÇÃo DA POLÍTICA DE MOBILIDADE URBANA

5.1 SIMULAÇÕES

5.2 RESULTADOS 92

5.3 GERAÇÃO DO ÍNDICE DE APLICABILIDADE DA POLÍTICA DE MOBILIDADE URBANA

5.4 TÓPICOS CONCLUSIVOS

6 VALIDAÇÃO DA FERRAMENTA - APLICAÇÃO EM ESTUDO DE CASO 104

6.1 CARACTERÍSTICAS LOCAIS 104

6.2 DADOS DE ENTRADA 111

6.3 RESULTADOS 114

6.4 TÓPICOS CONCLUSIVOS 126

7 CONCLUSÕES E RECOMENDAÇÕES 128

$\begin{array}{ll}\text { 7.1 CONCLUSÕES } & 128\end{array}$

7.2 RECOMENDAÇÕES 130

REFERÊNCIAS BIBLIOGRÁFICAS

$\begin{array}{ll}\text { APENDICE A } & 136\end{array}$

$\begin{array}{ll}\text { APENNDICE B } & 137\end{array}$ 


\section{LISTA DE TABELAS}

Tabela 4.1 - Comparativo entre paradigmas racionalista e construtivista............................ 67

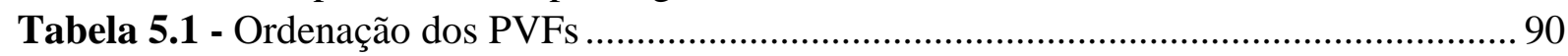

Tabela 5.2 - Atribuições de valores para as Cidades 1,2 e 3 ................................................ 91

Tabela 5.3 - Termômetros globais das avaliações PMU para as Cidades 1, 2 e 3

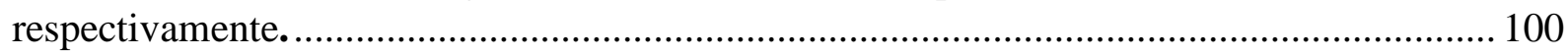

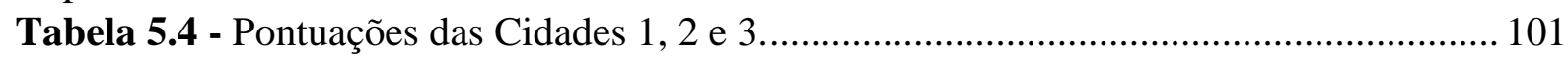

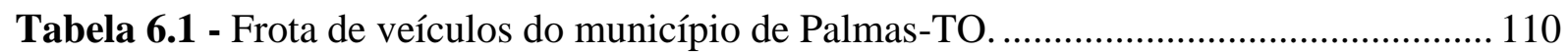

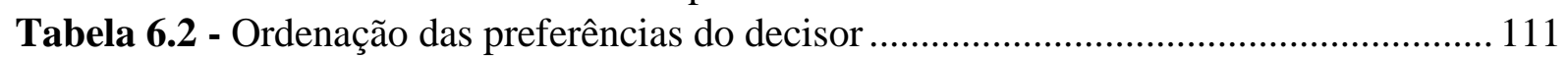

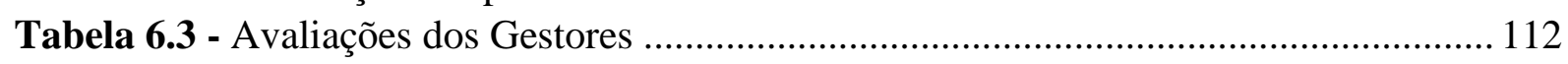

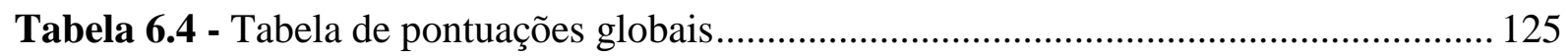




\section{LISTA DE FIGURAS}

Figura 1.1 - Elementos estratégicos para a mobilidade................................................... 21

Figura 2.1 - Estágios do ciclo político e sua relação com a aplicação de problemas.............. 25

Figura 2.2 - Muncípio e Constituição. Fonte: Elaboração própria.......................................... 28

Figura 2.3 - População dos municípios por grupos de tamanho populacional........................ 42

Figura 2.4 - Gráfico da divisão modal por porte de município - 2011 ................................. 42

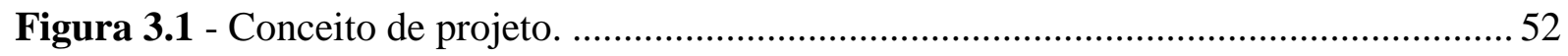

Figura 3.2 - Processos do Gerenciamento de Projetos. ............................................................... 53

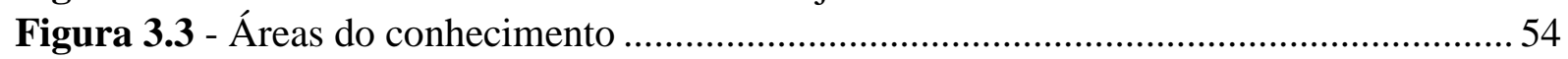

Figura 3.4 - Partes Interessadas - Stakeholders. ................................................................... 56

Figura 3.5 - Níveis típicos de custo e pessoal em toda a estrutura genérica do ciclo de vida de

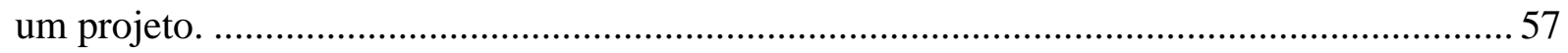

Figura 3.6 - Impacto da variável com base no tempo decorrido do projeto.............................57

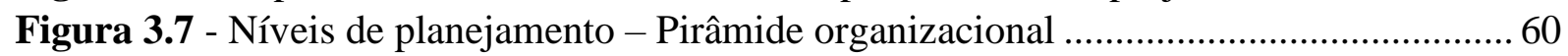

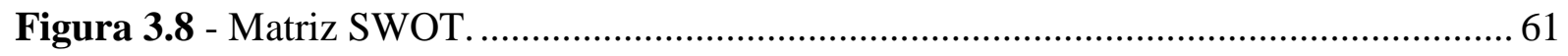

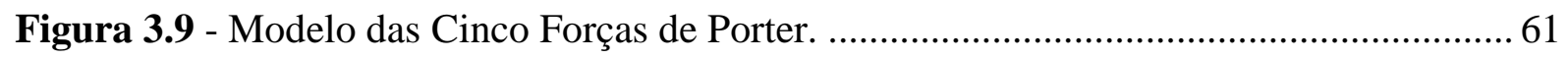

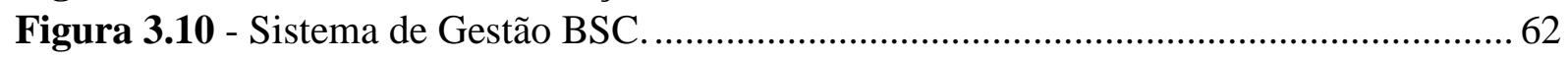

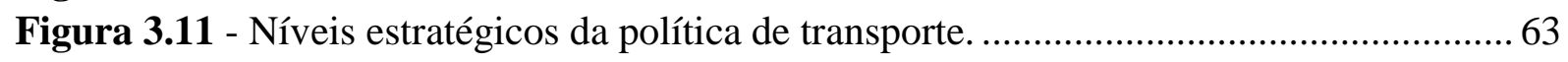

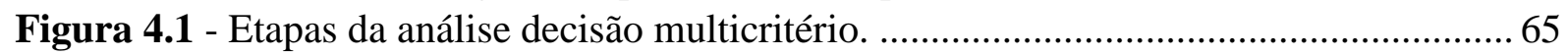

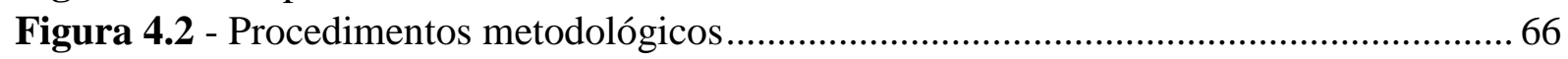

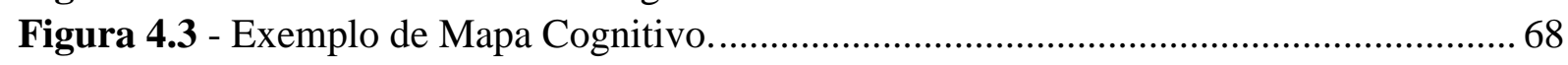

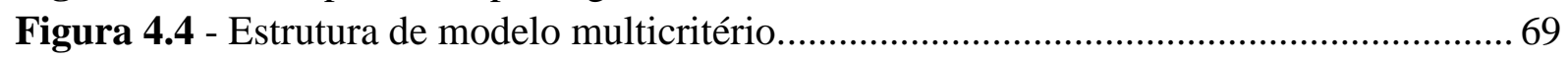

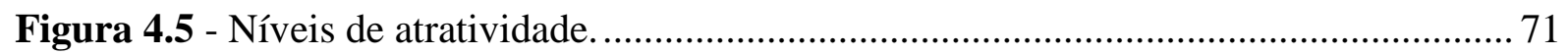

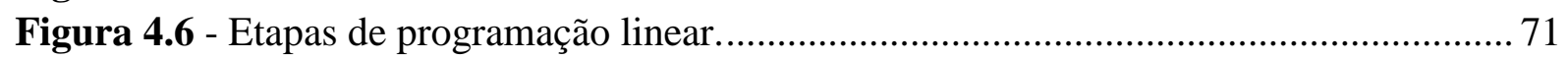

Figura 4.7 - Enquadramento do PV no processo decisório ................................................... 72

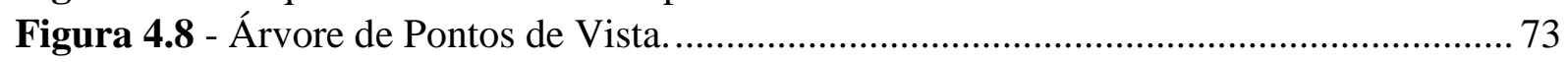

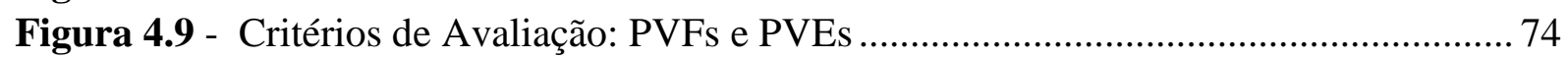

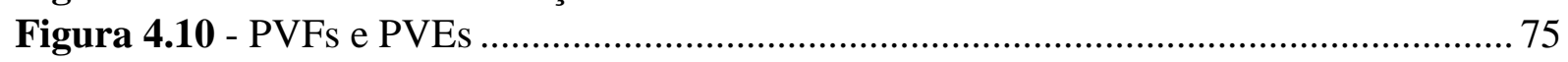

Figura 4.11 - Fundamentos dos critérios de avaliações a partir da Lei 12.587/2012 _............ 76

Figura 4.12 - Montagem da Matriz de Preferências............................................................... 77

Figura 4.13 - Descritor e seus níveis de impacto. .............................................................. 78

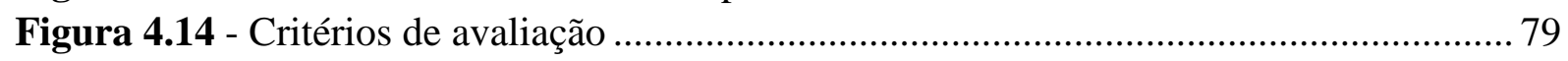

Figura 4.15 - Decomposição do eixo de avaliação do critério Governança............................ 80

Figura 4.16 - Organização dos critérios de avaliações e zona de admissibilidade ..................81 81

Figura 4.17 - Apresentação das opções comparáveis geradas no programa. .......................... 82

Figura 4.18 - Árvore de Pontos de Vista PVF e PVEs........................................................ 83

Figura 4.19 - Criação dos Pontos de Vista Fundamentais no M-Macbeth............................... 84

Figura 4.20 - Criação dos Pontos de Vista Elementares no M-Macbeth .................................. 84

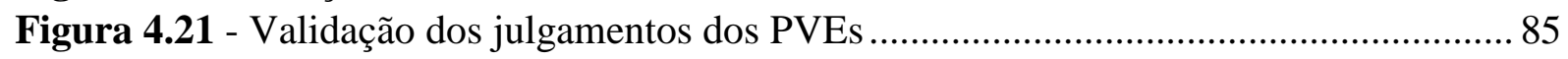

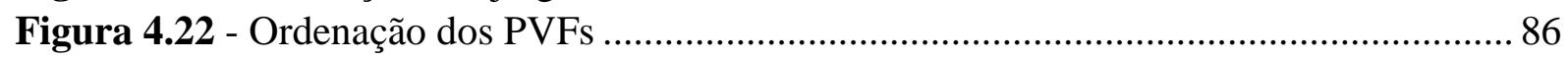

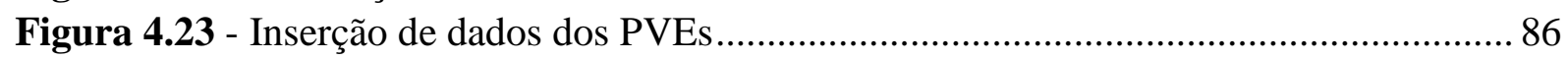

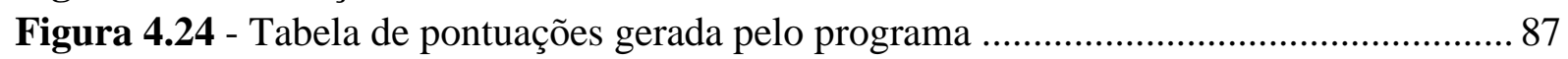

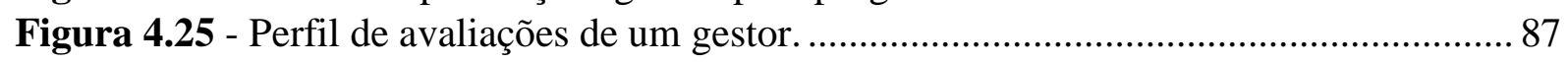

Figura 4.26 - Gráfico comparativo de resultados das avaliações da PMU ............................. 88 


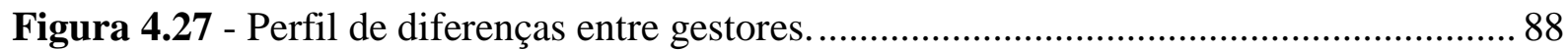

Figura 6.1 - Estado do Tocantins com o Município de Palmas em destaque........................ 104

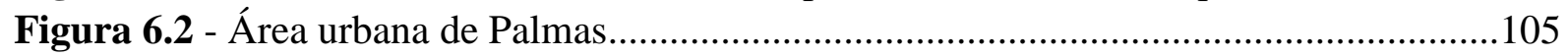

Figura 6.3 - Vista aérea do municipio de Palmas e rodovias..............................................106

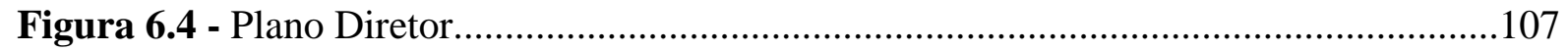

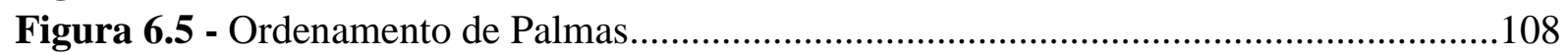

Figura 6.6 - Área Sul - deslocamento pendular.....................................................................109

Figura 6.7 - Secretaria Municipal de Acessibilidade, Mobilidade, Trânsito e Transporte.......111

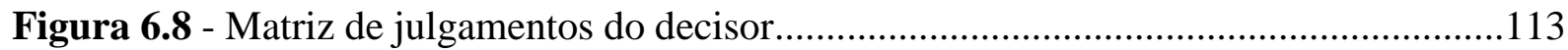

Figura 6.9 - Termômetro global para o Estudo de Caso........................................................124 


\section{LISTA DE QUADROS}

Quadro 2.1 - Conceitos e definições de política pública .................................................... 23

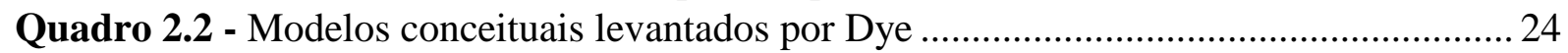

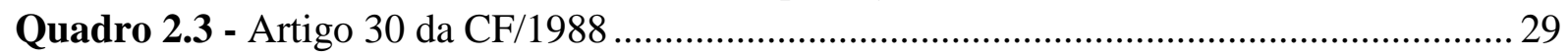

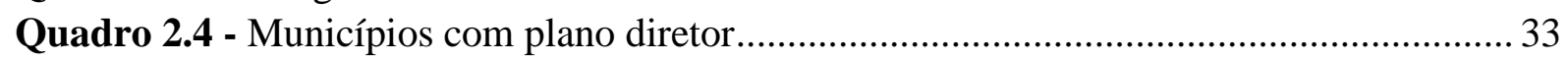

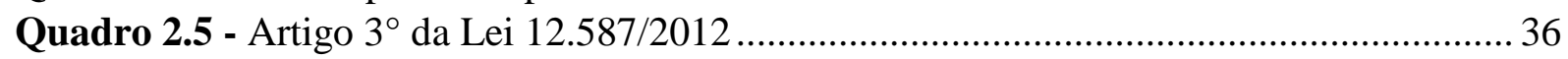

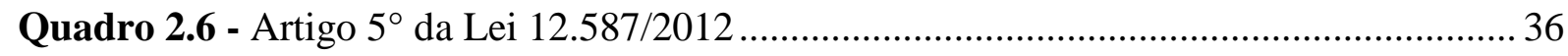

Quadro 2.7 - Artigo 6 $6^{\circ}$ da Lei 12.587/2012 ........................................................................... 38

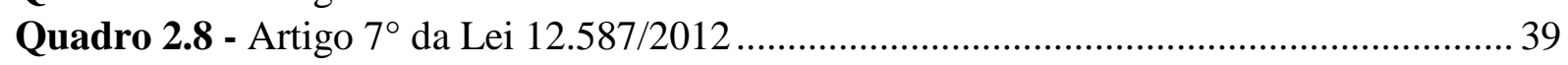

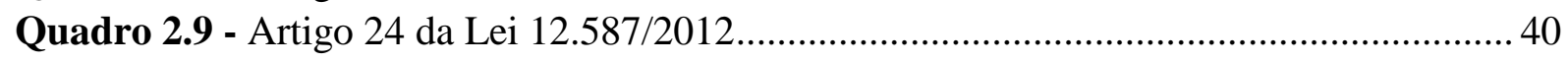

Quadro 2.10 - Art. 15 da Lei 12.587/2012 ..................................................................... 45

Quadro 2.11 - Municípios com Conselho Municipal de Política Urbana ou similar.............. 46

Quadro 3.1 - Conceitos e definições de gestão pública. ..................................................... 49

Quadro 3.2 - Definições de processos de gerenciamento. .................................................... 53

Quadro 3.3 - Definições das áreas do conhecimento de projetos ............................................54

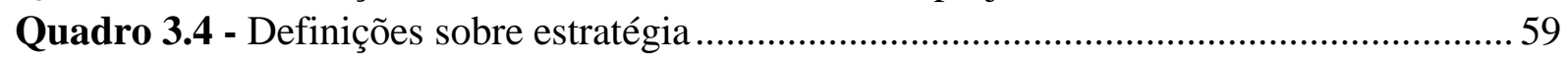

Quadro 4.1 - Pontos positivos e negativos de modelos MCDA …...................................... 70 


\section{LISTA DE GRÁFICOS}

Gráfico 5.1 - Valores de PMU para a Cidade 1................................................................. 92

Gráfico 5.2 - Resultados das avaliações do PVF Governança - Cidade 1............................. 92

Gráfico 5.3 - Resultados das avaliações do PVF Planejamento - Cidade 1. .......................... 93

Gráfico 5.4 - Resultados das avaliações do PVF Operações - Cidade 1 .............................. 93

Gráfico 5.5 - Resultados das avaliações do PVF Participação Social - Cidade 1. ................. 93

Gráfico 5.6 - Resultados das avaliações do PVF Meio Ambiente - Cidade 1........................ 94

Gráfico 5.7 - Resultados das avaliações PMU para a Cidade 2. ...........................................94

Gráfico 5.8 - Resultados das avaliações do PVF Governança - Cidade 2 ............................. 95

Gráfico 5.9 - Resultados das avaliações do PVF Planejamento - Cidade 2. .......................... 95

Gráfico 5.10 - Resultados das avaliações do PVF Operações - Cidade 2 . ............................ 95

Gráfico 5.11 - Resultados das avaliações do PVF Participação Social - Cidade 2 . .............. 96

Gráfico 5.12 - Resultados das avaliações do PVF Meio Ambiente - Cidade 2 ......................96

Gráfico 5.13 - Resultados das avaliações PMU para a Cidade 3. ......................................... 97

Gráfico 5.14 - Resultados das avaliações do PVF Governança - Cidade 3............................ 97

Gráfico 5.15 - Resultados das avaliações do PVF Planejamento - Cidade 3 ........................ 97

Gráfico 5.16 - Resultados das avaliações do PVF Operações - Cidade 3. ............................ 98

Gráfico 5.17 - Resultados das avaliações do PVF Meio Ambiente - Cidade 3..................... 98

Gráfico 5.18 - Resultados das avaliações do PVF Participação Social - Cidade 3. .............. 99

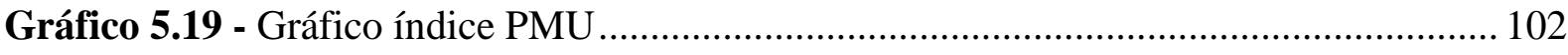

Gráfico 6.1 - Avaliações dos gestores no PVF Governança. .............................................. 114

Gráfico 6.2 - Avaliações dos gestores no PVF Participação Social...................................... 114

Gráfico 6.3 - Avaliações dos gestores no PVF Operações................................................. 115

Gráfico 6.4 - Avaliações dos gestores no PVF Planejamento............................................. 115

Gráfico 6.5 - Avaliações dos gestores no PVF Meio Ambiente .......................................... 116

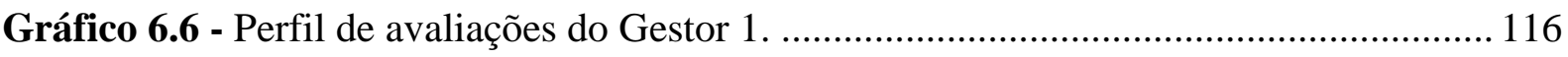

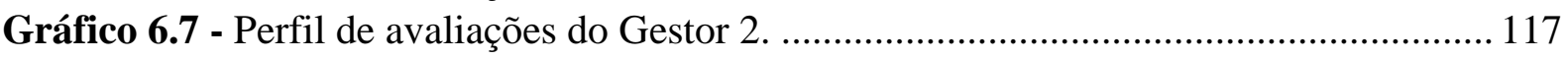

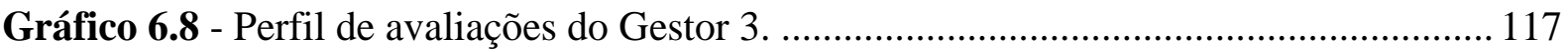

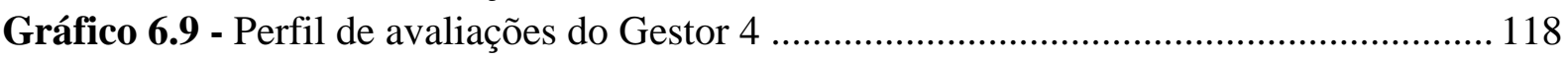

Gráfico 6.10 - Perfil de avaliações do Gestor 5. ................................................................. 118

Gráfico 6.11 - Perfil de diferenças entre o Gestor 1 e o Gestor 2 ........................................ 119

Gráfico 6.12 - Perfil de diferenças entre o Gestor 1 e o Gestor 3 .......................................... 119

Gráfico 6.13 - Perfil de diferenças entre o Gestor 1 e o Gestor 4......................................... 120

Gráfico 6.14 - Perfil de diferenças entre o Gestor 1 e o Gestor 5. .......................................... 120

Gráfico 6.15 - Perfil de diferenças entre o Gestor 2 e o Gestor 3. ....................................... 121

Gráfico 6.16 - Perfil de diferenças entre o Gestor 2 e o Gestor 4. ......................................... 121

Gráfico 6.17 - Perfil de diferenças entre o Gestor 2 e o Gestor 5. ......................................... 122

Gráfico 6.18 - Perfil de diferenças entre o Gestor 3 e o Gestor 4. ....................................... 122

Gráfico 6.19 - Perfil de diferenças entre o Gestor 3 e o Gestor 5........................................ 123

Gráfico 6.20 - Perfil de diferenças entre o Gestor 4 e o Gestor 5 ......................................... 123

Gráfico 6.21 - Índice da Política de Mobilidade Urbana (IPMU) - Palmas-TO................... 126 


\section{INTRODUÇÃO}

Neste capítulo inicial, será feita uma apresentação a respeito do trabalho e a delimitação do problema. Serão apresentados também as hipóteses e os objetivos a serem alcançados. Em seguida, serão expostas as justificativas da pesquisa e a metodologia deste estudo.

\subsection{APRESENTAÇÃo}

A Carta Magna de 1998 estruturou o federalismo nacional e conferiu autonomia políticaadministrativa aos Entes Federados, de forma que foi reservado um capítulo específico no próprio texto constitucional sobre a Organização do Estado. Em linhas gerais, passou-se a elencar as competências de cada Ente Federativo por meio do grau de interesse de cada matéria, ou seja, a União com competência para tratar de assuntos de interesse geral, os estados de interesse regional e os municípios com assuntos de interesse local.

Ainda que a Carta Política de 1988 tenha dado autonomia para estados e municípios, como o direito e a obrigação de promover e desenvolver suas políticas públicas, muitos aspectos dessa descentralização de autonomia, que possui pouco menos de três décadas, precisam ser discutidos e entendidos de forma profunda. Em especial a real capacidade de cada Ente Federativo conseguir a articulação político-social necessária para buscar seus objetivos.

Embora a Constituição Federal de 1988 tenha alterado, de forma significativa, o papel dos municípios como poder local na organização do Estado, não se pode negar o seu histórico de isolamento. Em consonância, Gohn (2002) cita que a volta do processo eleitoral em todas as localidades brasileiras possibilitou o acesso de representantes do campo democrático ao Poder Executivo, redefinindo o conceito de poder local, que passou a ser visto como espaço de gestão político-administrativa e não como simples sede das elites.

Decorridos alguns anos da promulgação da Constituição, os avanços promovidos pelo amadurecimento da democracia vêm caminhando em desequilíbrio, pois o poder local ainda não foi capaz de adquirir autonomia necessária para promover suas ações de forma totalmente independente, seja por critério político-social, derivado ainda dos "currais eleitorais", seja por incapacidade de gestão para formular suas políticas de desenvolvimento. 
Partindo desse princípio, em 10 de julho de 2001, foi promulgada a Lei 10.257, que regulamenta os artigos 182 e 183 da Constituição Federal e estabelece diretrizes gerais da política urbana e dá outras providencias. Essa Lei é conhecida como Estatuto da Cidade e estabelece normas de ordem pública e de interesse social que regulam o uso da propriedade urbana em prol do bem coletivo, da segurança e do bem-estar dos cidadãos.

Posteriormente, foi promulgada a Lei 12.587, de 2012, conhecida como Lei da Mobilidade Urbana, que descentraliza formalmente aos municípios a tarefa de planejar a Política Nacional de Mobilidade Urbana (PNMU). A lei determina que seus planos de mobilidade urbana priorizem o modo de transporte não motorizado e os serviços de transporte público coletivo; contudo, há um cenário de discussão anterior aos planos de mobilidade, ainda pouco explorado na literatura atual, que é a capacidade de gestão necessária para implementar tal política localmente.

Passados poucos anos da promulgação da Lei 12.587/2012, algumas perguntas precisam de respostas. Diante disso, como a autonomia municipal vem ocorrendo na prática? Em que medida e sob que condições a gestão estratégica dos municípios trabalha as demandas da Lei de Mobilidade? Como mensurar a eficiência da Política de Mobilidade Urbana (PMU) do município? Essas questões são vitais para entendermos em que situação se encontra a Política Nacional de Mobilidade Urbana em âmbito local.

\subsection{DELIMITAÇÃO DO PROBLEMA}

A PNMU passou a exigir dos municípios com população acima de 20 mil habitantes a construção de planos de mobilidade como elemento estratégico de integração do espaço urbano, por meio de melhorias no transporte de cada cidade. A partir desses elementos, surgem os seguintes problemas de pesquisa:

- $\quad$ os municípios possuem gestão estratégica aderente aos princípios, diretrizes e objetivos da Lei de Mobilidade Urbana, tornando-se capazes de impulsionar tal política pública em suas esferas locais?;

- $\quad$ de que forma poderia ser adotada uma ferramenta para avaliar a implementação da gestão estratégica em municípios frente à Política de Mobilidade Urbana? 
Nesse contexto, todas as questões levantadas na dissertação são aplicadas em estudo de caso concreto no município de Palmas, capital do Tocantins, determinando um parâmetro de aplicação da Lei 12.587/2012 à luz da gestão estratégica. O trabalho busca contribuir para a implementação e a avaliação da PNMU em território brasileiro, nos municípios que possuem obrigatoriedade de criar planos municipais de mobilidade.

Cabe ressaltar que a motivação para desenvolver tal tema partiu de uma análise feita no planejamento estratégico adotado pela Secretaria Municipal de Trânsito (SMT), de São Paulo, no período de 2011-2012. O processo de formulação da estratégia da SMT naquele período partiu da construção de blocos de política estratégica sob temas da PNMU.

De forma complementar, o trabalho contém a referência de duas dissertações do Programa de Pós-Graduação em Transportes da UNB: a de Luciany Oliveira Seabra e a de Aline Almeida Maia, intituladas respectivamente de "Metodologia para Gestão Estratégica do Transporte Público Urbano, baseada em Macroprocessos Estratégicos Organizacionais" (2008) e "Importância da Audiência Pública como Mecanismo de Participação Social em Projetos de Transportes" (2015).

\subsection{HIPÓTESES}

O processo de descentralização da PMU alcança municípios com tamanhos e capacidades distintas. A disposição da gestão estratégica voltada ao atendimento da Lei 12.587/2012 também congrega avaliações distintas, conforme o nível de sinergia entre elementos estratégicos da Lei e a gestão local. Nesse contexto, foram elaboradas as seguintes hipóteses:

- $\quad$ é possível realizar a avaliação da PNMU sob a ótica da gestão estratégica, por meio da criação de critérios de avaliação retirados da Lei 12.587/2012, mesmo que os critérios apontados pela própria Lei careçam de maior objetividade;

- $\quad$ a gestão estratégica da mobilidade, desenvolvida no espaço público municipal, não cumpre requisitos fundamentais previstos na Lei de Mobilidade, sendo um fator limitante o desalinhamento estratégico das estruturas implementadoras de gestão. 


\subsection{OBJETIVOS}

O objetivo geral desta pesquisa é propor uma ferramenta capaz de avaliar a efetividade da aplicação da política estratégica de mobilidade urbana no município. Para cumprir esse objetivo, será utilizada a ferramenta de análise multicritério Macbeth, que avalia o nível da gestão estratégica do município frente às demandas da PNMU, segundo direcionamentos estratégicos contidos na Lei 12.587/2012.

\section{São objetivos específicos:}

- $\quad$ discutir aspectos da mobilidade urbana por meio do arranjo federativo brasileiro da $\mathrm{CF} / 1988$;

- analisar o papel do município na Política Nacional de Mobilidade Urbana, frente ao processo de descentralização de políticas públicas e suas capacidades dentro desse escopo;

- $\quad$ analisar as condições necessárias para cumprir as exigências da Lei de Mobilidade Urbana;

- $\quad$ desenvolver uma ferramenta capaz de aferir a implementação da gestão estratégica do município no âmbito da Lei de Mobilidade, utilizando mecanismos de gestão e de análise multicritério de apoio a decisão;

- $\quad$ analisar os achados que a aplicação da ferramenta proposta produz.

\subsection{JUSTIFICATIVA}

A Constituição Federal de 1988 alterou de forma expressiva o significado de poder local, introduzindo subsídios que dão sustentação e autonomia política-administrativa ao ente municipal. A inserção de elementos jurídicos e políticos que tornam o ambiente institucionalizado e democrático são as bases dessa mudança e o motor para a transformação social das cidades. De fato, após o pacto federativo, os municípios se tornaram aptos a se articular com os estados e a União nos processos de formulação e implementação de políticas públicas.

A descentralização e a universalização da política federal de saúde e a consequente construção do Sistema Único de Saúde (SUS) passaram a ser normas constitucionais com a Constituição de 1988. O modelo foi assentado sobre o princípio contributivo de transferir aos municípios 
responsabilidades de gestão da prestação de serviços, mantendo a participação federal no financiamento da política (ARRETCHE, 2002). Posteriormente, tal modelo expandiu-se para a habitação (moradia) nos anos 2000, com o advento do Estatuto da Cidade. Em 2012, para o transporte, por meio da Lei de Mobilidade, que passou a ter status de direito social após a promulgação da Emenda Constitucional 90, de 2015.

Bonduki (1994) afirma que, após a Constituição de 1988, ocorreu uma progressiva transferência de atribuições para os estados e municípios que tornou a habitação uma atribuição concorrente dos três níveis de governo. O crescimento da mobilização dos movimentos de moradias ampliou a pressão por uma maior participação dos municípios na questão da habitação, pois a consolidação da democracia tornou o poder local o principal interlocutor das organizações populares.

De fato, a questão habitacional como direito social foi um dos motivadores para a descentralização das primeiras políticas públicas locais de urbanização, pois os sucessivos programas não conseguiam cobrir de maneira ampla seus objetivos. Embora a produção habitacional tenha sido significativa, ela esteve muito aquém das necessidades geradas pelo acelerado processo de urbanização que ocorreu no Brasil, na segunda metade do século XX. (BONDUKI, 2008)

Segundo Abrucio (2005, p.48),

as conquistas da descentralização não apagam os problemas dos governos locais brasileiros. Em especial, as questões que colocam obstáculos ao bom desempenho dos municípios do país: a desigualdade de condições econômicas e administrativas; o discurso do municipalismo autárquico; a metropolização acelerada; os resquícios ainda existentes tanto de uma cultura política como de instituições que dificultam a accountability democrática e o padrão de relações intergovernamentais.

Conforme Abrucio (2005, p.49-50),

o principal problema da descentralização ao longo da redemocratização foi a conformação de um federalismo compartimentalizado, em que cada nível de governo procurava encontrar seu papel especifico e não havia incentivos para compartilhamento de tarefas e atuação consorciada. Disso decorre também um jogo de empurra entre as esferas de governo.

Ainda que prevaleçam arcaicos modelos de política no Brasil, amparados pelas gramáticas clientelistas e pela ausência de confiabilidade da classe política, algumas tendências se formam no estreitamento da relação entre governo e cidadão. Alguns avanços são sentidos, e novos instrumentos de políticas públicas são sinalizados. Como exemplo mais recente, citam-se os 
conselhos de mobilidade urbana. Contudo, tudo depende da agenda política e quão é importante um determinado tema no rol de prioridades do governo local.

$\mathrm{Na}$ atual Constituição Federal, a autonomia política e fiscal dos governos estaduais e municipais permite que estes adotem uma agenda própria, independente da agenda do Executivo federal. As relações verticais na federação brasileira - do governo federal com Estados e municípios e dos governos estaduais com seus respectivos municípios - são caracterizadas pela independência, pois Estados e municípios são entes federativos autônomos. Nesse aspecto, em tese, as garantias constitucionais do Estado federativo permitem que os governos locais estabeleçam sua própria agenda na área social. (ARRETCHE, 2004, p.20)

Para um problema entrar na agenda, é determinante o processo político - e este tem uma dinâmica própria. Uma conjuntura política favorável para um problema entrar na agenda pode vir tanto de uma mudança de governo, que traz novos atores ao poder, como da atuação das forças organizadas da sociedade, que têm sucesso em levar suas demandas ao governo, como ainda das mudanças no "clima nacional" (national mood), ou seja, de uma situação onde as pessoas, por um determinado período de tempo, compartilham das mesmas questões. (GOMIDE, 2008)

No espaço compreendido entre a promulgação da CF/1988 e a entrada da Lei 12.587/2012, pouco se fez no âmbito da mobilidade urbana, ao passo que os problemas cresceram exponencialmente. Nesse campo, cita-se Maricato (2011, p.11):

apesar da produção significativa de Planos Nacionais, Metropolitanos e Municipais, bem como do arcabouço institucional criado pelo governo ditatorial, o destino das cidades pouco se alterou. Ainda assim, a atuação do Estado nesse período mostrou-se mais efetiva do que nas décadas seguintes, marcadas pela desregulamentação das políticas públicas e pelo recuo nos investimentos públicos.

Segundo Gomide (2008, p.15),

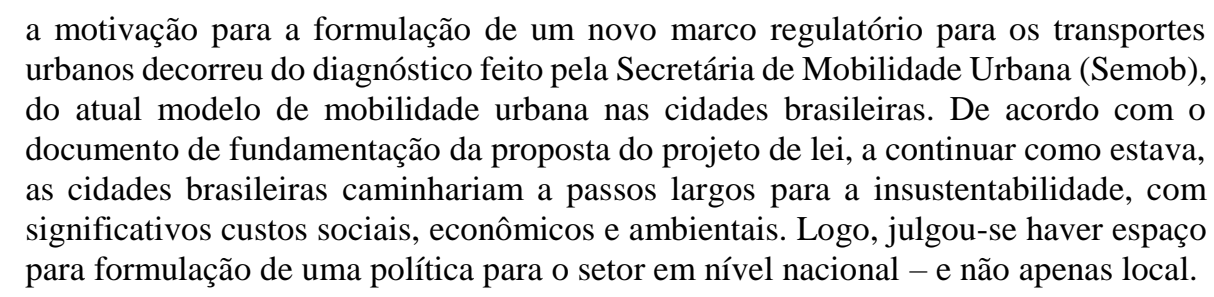

Nesse contexto de discussão, surge a PNMU. 
Nesse campo de discussão, também é necessário avaliar a capacidade estratégica gerencial de alguns municípios no que tange a aplicação de suas políticas de mobilidade. Este trabalho busca ampliar a discussão da implementação de políticas públicas de mobilidade à luz da gestão estratégica. Além de elevar a "conscientização" de que problemas de gestão pública-estratégica podem afetar a condução local da PNMU.

Alguns aspectos contemporâneos da gestão pública permanecem inalterados há décadas, ao mesmo tempo em que outros passaram por mudanças fundamentais, das quais uma merece destaque: a ênfase crescente no papel do gestor público como gerente. (PETERS \& PIERRE, 2010) A Fig. 1.1 abaixo evidencia algumas temáticas necessárias, que serão exploradas no trabalho como balizadores para a formação de uma gestão estratégica nos municípios, frente às demandas da PMU.

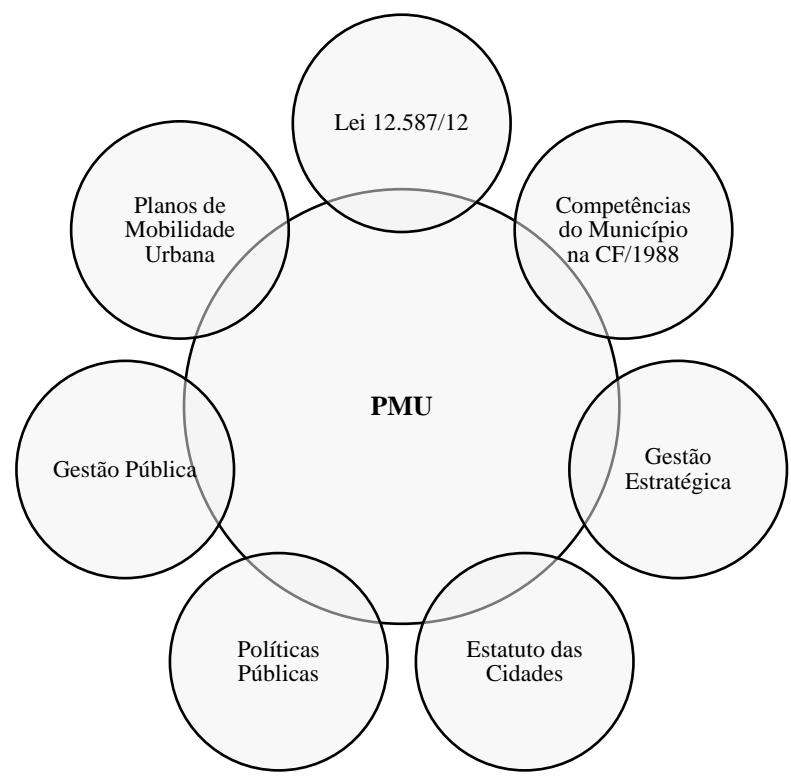

Figura 1.1 Elementos estratégicos para a mobilidade. Fonte: Adaptado PlanMob (2015)

O trabalho propõe desenvolver uma metodologia de avaliação do tipo adequação de desempenho, capaz de medir a eficácia da PNMU por meio da gestão estratégica do município, a fim de determinar se o programa está atingindo seus objetivos. Apesar do grau de subjetividade do método proposto, o apoio de uma ferramenta de análise multicritério participa da construção, com o objetivo de reduzir qualquer desequilíbrio do modelo.

Portanto, este trabalho se propõe a gerar conteúdo bibliográfico, científico e metodológico para embasar gestores e planejadores municipais na condução da política de mobilidade, sob o 
enfoque da gestão estratégica. E, assim, contribuir de forma contundente para o desenvolvimento social à luz da implantação da Lei 12.587/2012.

\subsection{ESTRUTURA DA DISSERTAÇÃO}

O primeiro capítulo corresponde à introdução e contempla toda a abordagem inicial da pesquisa, como problema, hipóteses, objetivos, justificativa, metodologia e estrutura do trabalho, dentro de um contexto racional de planejamento.

No capítulo 2, contextualiza-se o universo jurídico-administrativo em que se encontra o município. Nesse contexto, é discutida a política pública como processo, as competências municipais como ente federativo, autônomo e ator importante no cenário federativo. Também são abordadas premissas importantes do Estatuto da Cidade, como pré-requisito para a implantação de políticas de mobilidade urbana, e também a Lei 12.587/12 em seus aspectos mais importantes ao propósito do trabalho.

O capítulo 3 traz uma abordagem sobre aspectos importantes para a atuação administrativa do município. São apresentados conceitos e técnicas relevantes para a condução da gestão estratégica da mobilidade, segundo as exigências contidas no PNMU, e que são essenciais para a sua formulação e implantação. Nessa parte, são discutidas formas de gestão estratégica e instrumentos de planejamento, controle e execução de projetos.

O capítulo 4 define o método de análise multicritério a ser utilizado na avaliação da gestão estratégica em âmbito municipal. O método escolhido, o caráter subjetivo da avaliação e as formas de medição, sua aplicação e fluxo sistêmico para a avaliação dos resultados finais obtidos.

O capítulo 5 apresenta a aplicação da ferramenta de avaliação e faz um comparativo diante de simulações, além de apresentar seus resultados como uma prévia da aplicação prática.

O capítulo 6 corresponde à aplicação em estudo de caso da ferramenta no município de Palmas, capital do estado do Tocantins, e faz algumas observações a respeito dos resultados.

O capítulo 7 conclui o trabalho com observações e recomendações para aplicação e trabalhos futuros. 


\section{MUNICÍPIO E SUAS INTER-RELAÇÕES COM A POLÍTICA DE MOBILIDADE URBANA}

A partir da década de 2000, o governo federal passou a colocar na sua agenda as discussões sobre mobilidade urbana. No governo Fernando Henrique Cardoso, foi criada a Secretaria de Desenvolvimento Urbano da Presidência da República. Mais adiante, no governo Lula, foi tomada a iniciativa mais importante do tema, com a criação do Ministério das Cidades, que abrigou a Secretaria de Mobilidade. Esse sucinto contexto histórico é de vital importância para entender a inserção do capítulo na cronologia dos fatos, bem como para identificar o papel do município na Carta Magna de 1988.

O parágrafo inicial desta apresentação aguça a discussão sobre a temática da mobilidade urbana como política pública importante, cuja aplicabilidade depende da tomada de decisão efetiva em esfera municipal. O capítulo aborda de forma mais técnica e normativa artigos e questões importantes do Estatuto da Cidade e da Lei de Mobilidade Urbana para a construção do pleno entendimento deste estudo.

\subsection{TOMADA DE DECISÃO NO ÂMBITO DA POLÍTICA PÚBLICA}

Alguns conceitos de política pública, ou policy-making, tentam captar a ideia de que este é um processo técnico-político, que visa definir e compatibilizar objetivos e meios entre os diferentes atores sociais envolvidos na formulação e na execução da própria política pública. Algumas definições encontradas em meio acadêmico postulam, de alguma forma, que as políticas são ações intencionais de governos que contêm alguns objetivos articulados. Howlett (2015) destaca o conceito de estratégia segundo os autores no Quadro 2.1.

Quadro 2.1 Conceitos e definições de política pública

\begin{tabular}{|c|l|}
\hline Autor & \multicolumn{1}{|c|}{ Definição } \\
\hline $\begin{array}{c}\text { Dye } \\
\text { (1972) }\end{array}$ & $\begin{array}{l}\text { Política pública é tudo o que um governo decide fazer ou deixar de fazer. } \\
\text { (DYE, 1972 apud HOWLETT, 2013, p. 6). }\end{array}$ \\
\hline $\begin{array}{c}\text { Jenkins } \\
\mathbf{( 1 9 7 8 )}\end{array}$ & $\begin{array}{l}\text { "[...] um conjunto de decisões inter-relacionadas, tomadas por um ator ou } \\
\text { grupo de atores políticos, e que dizem respeito à seleção de objetivos e dos } \\
\text { meios necessários para alcançá-los, dentro de uma situação especifica em que } \\
\text { o alvo dessas decisões estaria em princípio, ao alcance desses atores." } \\
\text { (JENKINS, 1978 apud HOWLETT, 2013, p. 8). }\end{array}$ \\
\hline
\end{tabular}




\begin{tabular}{|c|c|}
\hline $\begin{array}{l}\text { Theodore } \\
\text { Lowi } \\
\text { (1972) }\end{array}$ & $\begin{array}{l}\text { "A política pública (policy) pode determinar a política (politics), e não o } \\
\text { contrário como em geral supõe a maioria dos analistas." (THEODORE } \\
\text { LOWI, } 1972 \text { apud HOWLETT, 2013, p. 11). }\end{array}$ \\
\hline $\begin{array}{l}\text { Laster } \\
\text { Salamon } \\
(\mathbf{1 9 8 1 )}\end{array}$ & $\begin{array}{l}\text { "O enfoque na natureza das ferramentas ou dos instrumentos que os governos } \\
\text { têm à sua disposição para implementar políticas públicas, é a melhor forma } \\
\text { de análise disponível para a compreensão da política pública." (LESTER } \\
\text { SALAMON, } 1981 \text { apud } \text { HOWLETT, 2013, p. 11). }\end{array}$ \\
\hline
\end{tabular}

Fonte: Adaptado Howlett (2013)

Segundo Dye (2005), a ciência política, ao longo dos anos, a maneira de outras disciplinas científicas, desenvolveu uma série de modelos conceituais para ajudar a entender a vida política. O Quadro 2.2 cita alguns modelos levantados por Dye em sua obra Models of Politic: some helps in thinking about public policy.

Quadro 2.2 Modelos conceituais levantados por Dye (2005)

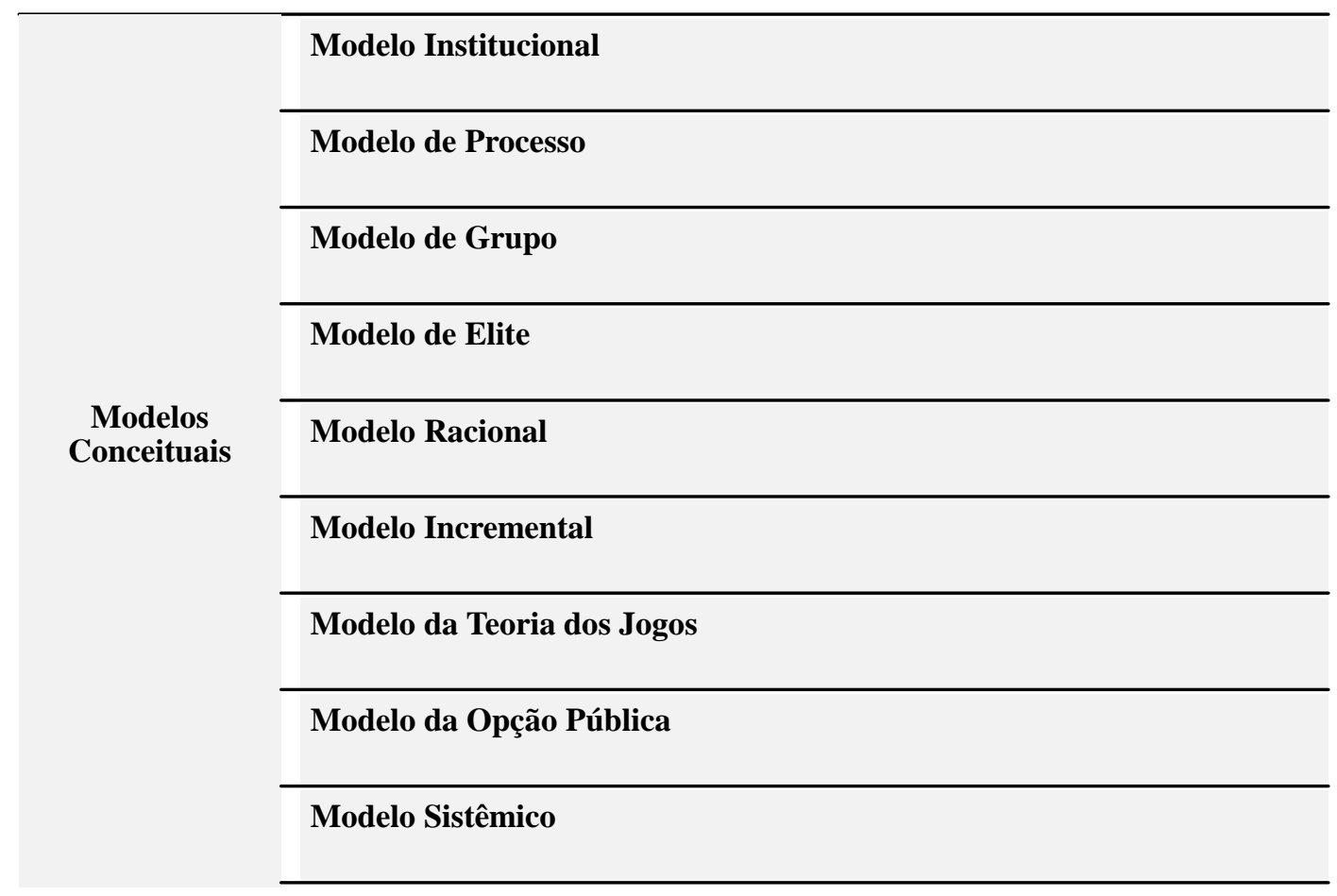

Fonte: Adaptado Dye (2005)

Um dos meios mais populares de simplificar a policy-making, para fins analíticos, foi pensá-la como processo, isto é, como um conjunto de estágios inter-relacionados por meio dos quais os temas políticos e as deliberações fluam de uma forma mais ou menos sequencial desde os insumos (problemas) até os produtos (políticas). A ideia de simplificar a policy-making em vários estágios discretos foi mencionada pela primeira vez por Harold Lasswell. (PETERS \& PIERRE, 2001) 
Em seu trabalho, Lasswell dividiu o processo da política pública em sete estágios, os quais descrevem não só como as políticas eram de fato citadas, mas como deveriam ser agregadas, ou produzidas. São eles: informação, promoção, prescrição, invocação, aplicação, término e avaliação, cuja sequência é similar a um plano estratégico com começo, meio e fim.

A formulação de Lasswell serviu de base para muitos outros modelos. Um exemplo típico foi a versão mais simples do ciclo político-administrativo, desenvolvida por Gary Brewer em 1974.

A versão de Brewer do processo político-administrativo representou um aperfeiçoamento em relação ao trabalho pioneiro de Lasswell, ao ultrapassar as fronteiras do governo na exploração do modo como os problemas são reconhecidos e solucionados. Ela esclareceu também a terminologia usada para descrever os vários estágios apontados e inseriu a noção de processo na política pública como um ciclo em constante movimento.

Os estudos de Brewer motivaram o desenvolvimento de várias outras versões de ciclo políticoadministrativo nas décadas de 1970 e 1980, sendo mais conhecidos os que constaram nos livrostexto de Charles O. Jones e James Anderson. (HOWLETT, 2015)

As fases na resolução aplicada de problemas e os estágios correspondentes no processo da política pública estão ilustrados abaixo, na Fig. 2.1:

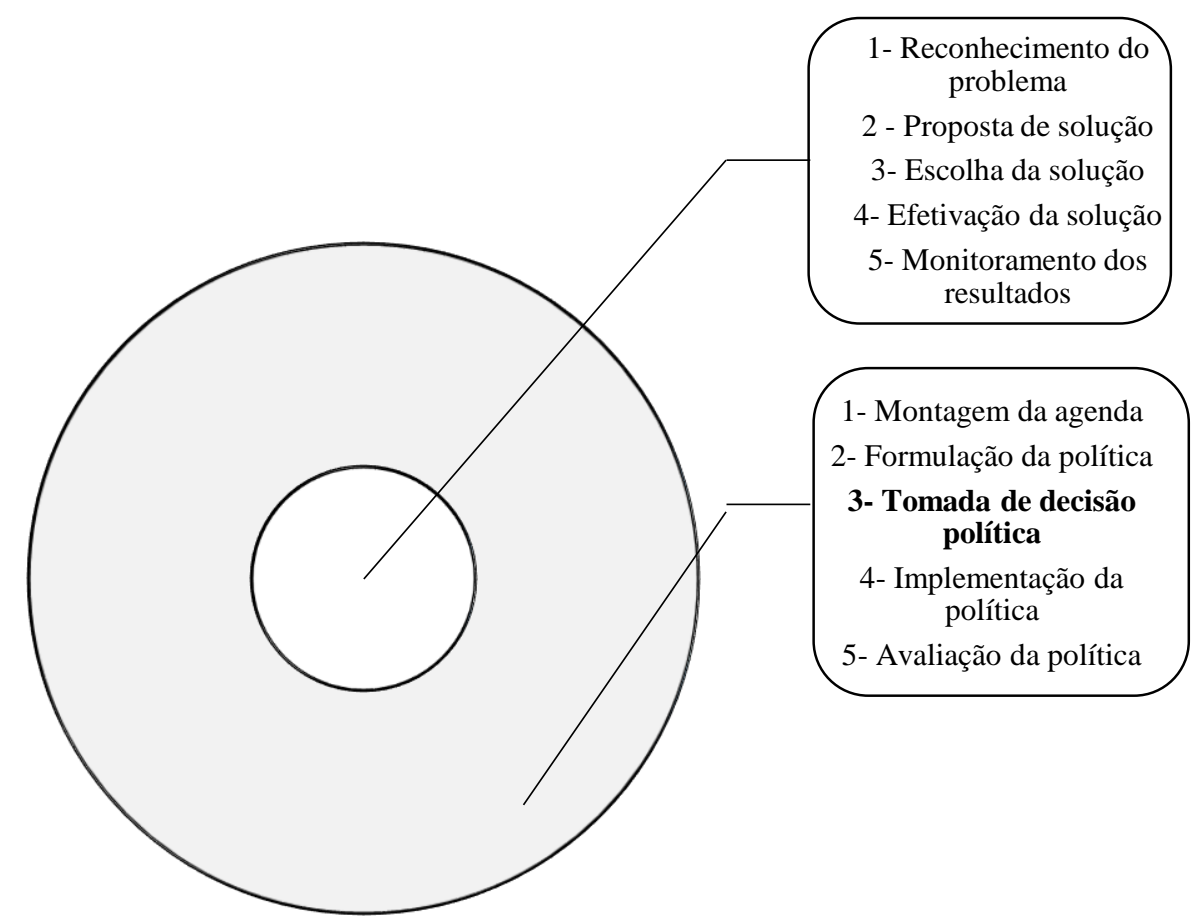

Figura 2.1 Estágios do ciclo político e sua relação com a aplicação de problemas. Fonte: Elaboração própria 
Nesse modelo:

- Montagem da agenda: refere-se ao processo pelo qual os problemas chegam à atenção dos governos. A política pública começa quando a agenda é definida;

- $\quad$ Formulação da política: diz respeito ao modo como as propostas de política se relacionam à formulação de políticas em âmbito governamental;

- Tomada de decisão: é o processo pelo qual os governos adotam um curso de ação ou de não ação;

- Implementação da política: relaciona-se ao modo pelo qual os governos dão curso efetivo a uma política;

- Avaliação da política: refere-se aos processos pelos quais tanto os atores estatais como os societários monitoram os resultados das políticas.

O estágio que será discutido de forma mais aplicada neste trabalho será o estágio da tomada de decisão, tendo em vista que o referido trabalho está apoiado num modelo de Análise Multicritério de Apoio à Decisão (MCDA), no estágio da tomada de decisão política. Nesse sentido, cabe ressaltar que, no processo político, o número de atores políticos tende a reduzir substancialmente, pois geralmente se concentram em torno daquele que ocupam cargos formais no governo. Mas isso não deve excluir outros atores de participar e influenciar no processo de decisão.

Diferentemente do espaço privado, na arena pública governamental o nível de liberdade do tomador de decisão está restrito por um grande número de regras institucionais, dentro do contexto político-administrativo. Pode se estabelecer, como exemplo, a existência de mecanismos de monitoramento entre os poderes, fundamentado em um sistema de freios e contrapesos, onde há controle entre os poderes no âmbito da tomada de decisão.

Gary Brewer e Peter DeLoren caracterizam o estágio da tomada de decisão do processo de política pública como:

A escolha entre as alternativas de políticas que foram geradas e seus prováveis efeitos sobre o problema em questão (...) É o estágio mais evidentemente político, na medida em que as muitas soluções potenciais para um dado problema devem, de algum modo, ser reduzidas a apenas uma ou umas poucas eleitas e preparadas para uso. Naturalmente, as escolhas possíveis, em sua maior parte, não serão todas realizadas e a decisão de não tomar determinados cursos de ação é parte da seleção assim como é a definição final do melhor curso (Brewer \& DeLeon 1983, p. 179). 
Bryner (1987) destaca a importância do papel dos especialistas na aceitação da tomada de decisão em ambiente democrático e no comprometimento em trabalhar com não especialistas na avaliação das escolhas de políticas e na aplicação das decisões sobre políticas. Nesse sentido, assegurar que os funcionários burocráticos representem afinidades demográficas e ideológicas diversas e reflitam as diferentes visões no interior das sociedades em que atuam é essencial.

Nesse contexto, a dinâmica das ações se concentra em formular estratégias baseadas em processos robustos de execução, de modo a facilitar a tomada de decisão do gestor público (decisor) na aplicação de políticas públicas. Cabe aqui destacar a importância de definir as competências do município, como campo de aplicação descentralizado de políticas públicas na Constituição de 1988, com a finalidade de perceber o ambiente político e institucional característico do espaço local.

\subsection{COMPETÊNCIAS DO MUNICÍPIO}

Dispõe o art. $1^{\circ}$ da CF/1988: “A República Federativa do Brasil, formada pela união indissolúvel dos Estados e Municípios e do Distrito Federal, constitui-se em Estado Democrático de Direito"; e, no mesmo sentido, o art.18 disciplina que "a organização políticoadministrativa da República Federativa do Brasil compreende a União, os Estados, o Distrito Federal e os Municípios, todos autônomos, nos termos desta Constituição".

O federalismo moldado pela Constituição de 1988 é, ao menos em sua potencialidade, um exemplo de federalismo cooperativo (BERCOVICI, 2004), na medida em que, de forma inédita, o texto constitucional prevê uma série de competências que são atribuídas a mais de um ente da federação. O centralismo exclusivista do período anterior cede lugar, portanto, a uma exigência de maior interação e articulação entre esses diversos entes (União, estados, Distrito Federal e municípios).

A passagem de um federalismo apenas nominal para um federalismo, em tese, cooperativo fez com que alguns autores sustentassem a tese de que a federação brasileira seria uma federação de estados fortes. (ABRUCIO, 1998) Não há dúvidas de que, se a base de comparação for o regime anterior, a Constituição de 1988 reforçou o papel dos estados e dos municípios no arranjo federativo. Assim demonstra a Fig. 2.2, ao enfatizar de forma cronológica o papel do município em cada Constituição. 


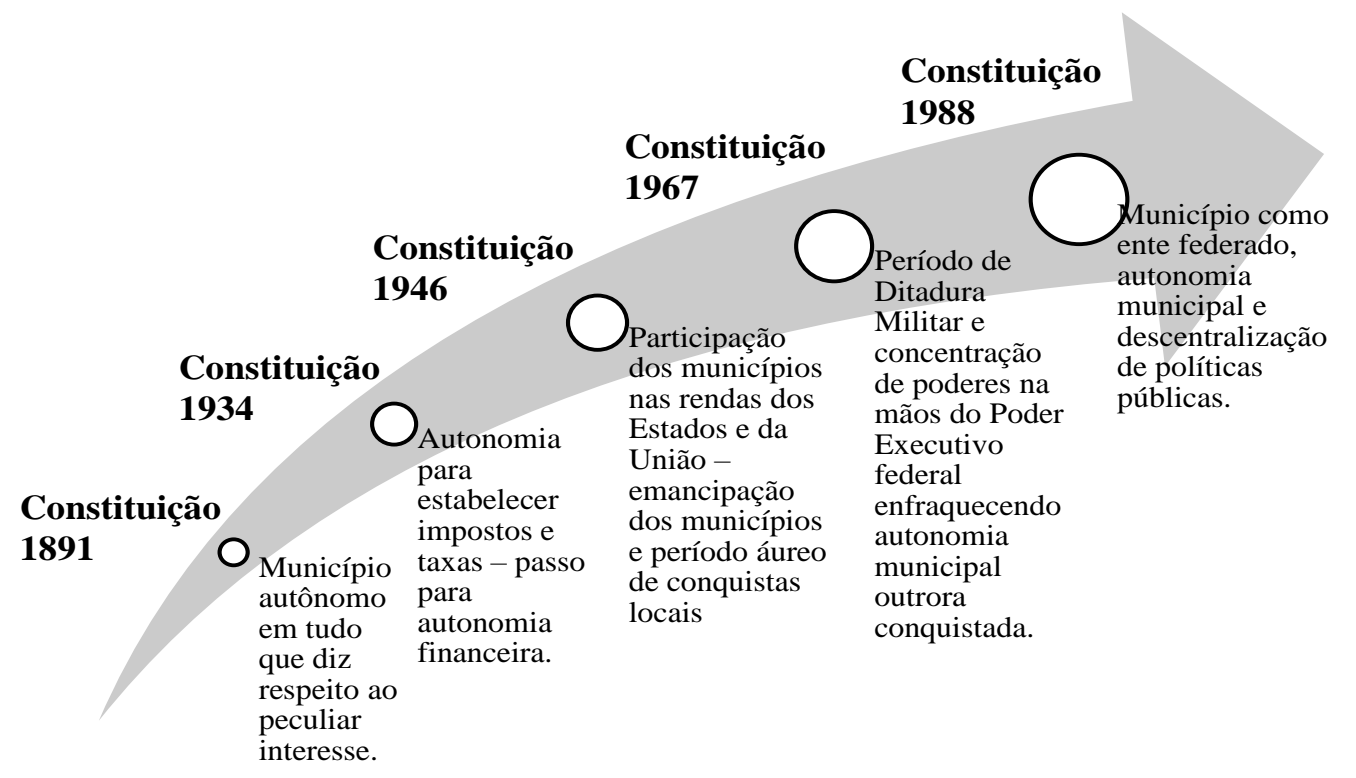

Figura 2.2 Muncípio e Constituição. Fonte: Elaboração própria.

A repartição de competências pode, em estados federais, seguir critérios bastante distintos. Essa variedade de critérios decorre das possibilidades de combinação entre competências enumeradas, remanescentes, comuns e concorrentes. Não seria exagero afirmar que, especialmente no âmbito da realização de políticas públicas, o êxito de uma coordenação federativa é a linha que separa um federalismo cooperativo de um federalismo competitivo ou até mesmo predatório. Segundo Abrucio (2005):

O principal problema da descentralização de políticas públicas ao longo da redemocratização foi a conformação de um federalismo compartimentalizado, em que cada nível de governo procurava encontrar seu papel específico e não havia incentivos para compartilhamento de tarefas e atuação consorciada. Disso decorre um jogo de empurra entre as esferas de governo.

O modelo de repartição de competências articulado pela Constituição de 1988 está sujeito a uma série de dificuldades interpretativas. No arts. 21 e 23, a Constituição elenca uma série de competências não legislativas e as atribui, no primeiro caso (art. 21), privativamente à União e, no segundo (art. 23), à União, aos estados, ao Distrito Federal e aos municípios. Esse último rol é chamado de rol de competências comuns.

No caso dos municípios, objeto de estudo deste trabalho, a autonomia vem disciplinada no art. 30 da Lei Fundamental (Quadro 2.3) e representa a capacidade de auto-organização, autogoverno, autolegislação, e autoadministração, caracterizando a autonomia política, normativa, administrativa e financeira dos municípios, que são elementos necessários para o emprego efetivo de políticas públicas. 
Quadro 2.3 Artigo 30 da CF/1988

\begin{tabular}{|c|c|}
\hline Art. 30 & Compete aos Municípios: \\
\hline I & Legislar sobre assuntos de interesse local; \\
\hline II & Suplementar a legislação federal e a estadual no que couber; \\
\hline III & $\begin{array}{l}\text { Instituir e arrecadar os tributos de sua competência, bem como aplicar suas rendas, } \\
\text { sem prejuízo da obrigatoriedade de prestar contas e publicar balancetes nos prazos } \\
\text { fixados em lei; }\end{array}$ \\
\hline IV & Criar, organizar e suprimir distritos, observada a legislação estadual; \\
\hline $\mathrm{V}$ & $\begin{array}{l}\text { Organizar e prestar, diretamente ou sob regime de concessão ou permissão, os } \\
\text { serviços públicos de interesse local, incluído o de transporte coletivo, que tem } \\
\text { caráter essencial; }\end{array}$ \\
\hline VI & $\begin{array}{l}\text { Manter, com a cooperação técnica e financeira da União e do Estado, programas } \\
\text { de educação infantil e de ensino fundamental; }\end{array}$ \\
\hline VII & $\begin{array}{l}\text { Prestar, com a cooperação técnica e financeira da União e do Estado, serviços de } \\
\text { atendimento à saúde da população; }\end{array}$ \\
\hline VIII & $\begin{array}{l}\text { Promover, no que couber, adequado ordenamento territorial, mediante } \\
\text { planejamento e controle do uso, do parcelamento e da ocupação do solo urbano; }\end{array}$ \\
\hline IX & $\begin{array}{l}\text { Promover a proteção do patrimônio histórico-cultural local, observada a legislação } \\
\text { e a ação fiscalizadora federal e estadual. }\end{array}$ \\
\hline
\end{tabular}

Fonte: Constituição Federal de 1988

Por meio do pacto federativo, estabelecido na Constituição de 1988, foi atribuída ao município a condição de ente federativo autônomo. A organização político-administrativa da República Federativa do Brasil compreende a União, os estados, o Distrito Federal e os municípios, todos autônomos, nos termos da Constituição Cidadã.

A Carta Magna de 1988 reparte competências entre as pessoas jurídicas de direito público interno que compõem o Estado brasileiro. Repartição essa que converge o interesse como forma 
de repartição de competência, cabendo à União as matérias de interesse nacional ou geral, aos estados as matérias de interesse regional e aos municípios as de interesse local.

O município recebeu da Constituição Federal de 1988 as seguintes competências:

- $\quad$ suplementar a legislação federal e estadual urbanística, quando couber (art. 30, II);

- $\quad$ promover o adequado ordenamento territorial, mediante planejamento e controle do uso, do parcelamento e da ocupação de solo urbano (art. 30, VIII);

- $\quad$ estabelecer a política de desenvolvimento urbano, observadas as regras da lei federal (art. 182, caput);

- $\quad$ elaborar o plano diretor, obrigatório para cidades com mais de vinte mil habitantes (art. $\left.182, \S 1^{\circ}\right)$;

- $\quad$ exigir, em face de proprietários do solo urbano, adequação de sua propriedade imobiliária ao plano diretor da cidade (art. 182, $\S 4^{\circ}$ );

- aplicar as medidas punitivas de parcelamento e edificação compulsórios; IPTU progressivo no tempo; e desapropriação urbanística sancionatória (art. 182, § $4^{\circ}$, I a III).

Segundo Santos Júnior (2000. p,10),

desde o início dos anos 90, assiste-se a um crescente processo de descentralização e municipalização das políticas públicas, intensificado não somente pela elaboração das Constituições Estaduais e das Leis Orgânicas Municipais - estas elaboradas pela primeira vez de forma autônoma pelos municípios -, mas também por um conjunto de leis e políticas, federais e estaduais, de incentivo e de transferência de competências para o âmbito municipal. Não restam dúvidas, os municípios ganharam poder.

Segundo Arretche (2002.p,335),

a autonomia local para a gestão de políticas cria oportunidades institucionais para que os governantes implementem decisões de acordo com suas próprias preferências, as quais não são necessariamente compatíveis com o interesse público e o bem-estar da população.

Nesse contexto, a responsabilidade e a competência da gestão política-estratégica local passam a ter um peso significativo na aplicação de políticas públicas do ente municipal.

\subsection{ESTATUTO DAS CIDADES}

No período que compreendia a construção da Carta Política de 1988, foi dado destaque constitucional à propriedade, quando inserida no texto Constitucional a proteção jurídica da função social da propriedade, com status de direito fundamental. Essa ação estimulou e 
provocou a promulgação da Lei 10.257/2001, conhecida como Estatuto da Cidade, que solidificou as bases para a organização dos municípios.

Segundo Maricato (2003), a eleição de governos municipais democráticos que testaram políticas sociais participativas, as lutas sociais pela mudança dos marcos legais que regulam o uso e a ocupação do solo lograram apresentar avanços no fim do século XX. Também não se pode negar que a Constituição Federal de 1988 e o Estatuto da Cidade constituem paradigmas inovadores e modernizantes no que diz respeito às relações de poder sobre a base fundiária e imobiliária urbana.

O regime da política constitucional urbana decorre da associação entre os artigos 182 e 21, inciso XX, da Constituição Federal. Tais dispositivos ratificam a política de desenvolvimento urbano, executada pelo Poder Público municipal. As diretrizes gerais fixadas no Estatuto das Cidades direcionam os macro-objetivos para o ordenamento e o desenvolvimento das funções sociais da cidade.

A Lei 10.257/2001, denominada Estatuto da Cidade, regulamenta os arts. 182 e 183 da CF e estabelecer diretrizes gerais de política urbana endereçada ao município, de acordo com a competência constitucional que lhe é atribuída:

Art.182. A política de desenvolvimento urbano, executada pelo poder público municipal, conforme diretrizes gerais fixadas em lei, tem por objetivo ordenar o pleno desenvolvimento das funções sociais da cidade e garantir o bem estar de seus habitantes.

Assim estabelece o Estatuto da Cidade em seu art. $2^{\circ}$ : “A política urbana tem por objetivo ordenar o pleno desenvolvimento das funções sociais da cidade e da propriedade urbana, mediante as seguintes diretrizes gerais".

Dessa forma, no que tange a instrumentos da política urbana inseridos na Lei 10.257/2001, o art. $4^{\circ}$ descreve os seguintes instrumentos, entre outros:

- $\quad$ planos nacionais, regionais e estaduais de ordenação do território e de desenvolvimento econômico e social;

- $\quad$ planejamento das regiões metropolitanas, aglomerações urbanas e microrregiões; 
- $\quad$ planejamento municipal, em especial: plano diretor; disciplina do parcelamento, do uso e ocupação do solo; zoneamento ambiental; gestão orçamentária participativa; planos de desenvolvimento econômico e social; programas e projetos setoriais; plano plurianual; diretrizes orçamentárias e orçamento anual.

De acordo com o Ministério das Cidades, o plano diretor é o principal instrumento instituído pelo Estatuto da Cidade, reunindo os demais instrumentos e estabelecendo como cada porção do território municipal cumpre sua função social. É uma lei municipal, que deve ser revista a cada dez anos, e deve expressar a construção de um pacto social, econômico e territorial para o desenvolvimento urbano e Municipal. (BRASIL, 2010)

Assim estabelece a Constituição Federal de 1988:

Art. 182. A política de desenvolvimento urbano, executada pelo Poder Público municipal, conforme diretrizes gerais fixadas em lei, tem por objetivo ordenar o pleno desenvolvimento das funções sociais da cidade e garantir o bem-estar de seus habitantes.

$\S 1^{\circ}$ - O plano diretor, aprovado pela Câmara Municipal, obrigatório para cidades com mais de vinte mil habitantes, é o instrumento básico da política de desenvolvimento e de expansão urbana.

$\S 2^{\circ}$ - A propriedade urbana cumpre sua função social quando atende às exigências fundamentais de ordenação da cidade expressas no plano diretor.

No âmbito governamental do Estatuto da Cidade, plano que interessa a este trabalho, as medidas ocorrem no campo legislativo e administrativo. No campo legislativo, o Poder Público se encarrega de editar leis e atos análogos que vão regular a atuação no plano administrativo. No campo administrativo, ocorre a transformação do plano abstrato contido na lei em planos operacionais para efetivação da ordem urbanística, por meio das ações de planejamento local.

O planejamento constitui um dos princípios básicos do Poder Público. Até a vigente Constituição refere-se ao planejamento, quando, por exemplo, confere à União competência para elaborar e executar planos nacionais e regionais de ordenação do território (art.21, IX), ou quando atribui ao município a tarefa de promover o adequado ordenamento territorial, mediante planejamento e controle do solo urbano. (BRASIL, 1988)

As cidades resultam de uma rede robusta e complexa de relações sociais, de maneira que somente por meio de mecanismos e instrumentos de planejamento a administração pública poderá prover o desenvolvimento geográfico adequado. Consoante o Estatuto das Cidades, o planejamento precisará atuar em três níveis fundamentais, que compreendem o 
desenvolvimento das cidades, a distribuição espacial da população e as atividades econômicas do município.

A organização e a distribuição espacial são orientadas pelo plano diretor de cada cidade, que é um instrumento essencial para aplicar recursos públicos por meio de políticas públicas orientadas e setorizadas. O plano diretor está definido no Estatuto das Cidades como instrumento básico para orientar a política de desenvolvimento e de ordenamento da expansão urbana e territorial do município.

A implantação da política de desenvolvimento urbano configura um grande desafio aos municípios de pequeno e médio porte, pois estes possuem reduzida competência técnica e financeira. No entanto, o Estatuto não obriga a elaboração do plano diretor em municípios com população inferior a vinte mil habitantes. Grande parte dos municípios brasileiros aprovou seus planos diretores seguindo as disposições do Estatuto da Cidade; contudo, falta uma metodologia de fácil aplicação que venha a promover uma maior participação dos municípios. O Quadro 2.4 evidencia a quantidade de municípios que possuem plano diretor:

Quadro 2.4 Municípios com plano diretor

\begin{tabular}{|c|c|c|c|c|}
\hline \multirow{3}{*}{$\begin{array}{c}\text { Municípios por } \\
\text { tamanho da população }\end{array}$} & \multicolumn{4}{|c|}{ Municípios } \\
\hline & \multirow{2}{*}{ Total } & \multicolumn{2}{|c|}{ Com Plano Diretor } & \multirow{2}{*}{$\begin{array}{l}\text { Elaborando o } \\
\text { Plano Diretor }\end{array}$} \\
\hline & & Total & $\begin{array}{c}\text { Revendo o } \\
\text { Plano Diretor }\end{array}$ & \\
\hline Brasil & 5.565 & 2.658 & 789 & 809 \\
\hline Até 5.000 & 1.298 & 328 & 58 & 222 \\
\hline De 5.001 a 10.000 & 1.210 & 352 & 76 & 207 \\
\hline De 10.001 a 20.000 & 1.388 & 474 & 139 & 278 \\
\hline De 20.001 a 50.000 & 1.054 & 900 & 266 & 94 \\
\hline De 50.001 a 100.000 & 327 & 318 & 124 & 7 \\
\hline De 100.001 a 500.000 & 250 & 248 & 110 & 1 \\
\hline Mais de 500.000 & 38 & 38 & 16 & 0 \\
\hline
\end{tabular}

Fonte: IBGE (2012)

Segundo Bonduki (2007, p.77),

o crescimento da mobilização dos movimentos de moradias ampliou a pressão por uma maior participação dos municípios na questão da habitação, pois a consolidação da democracia tornou o poder local o principal interlocutor das organizações populares e o responsável pelo equacionamento das demandas sociais, estando em contato direto com os problemas da população. 
Conforme Maricato (2001), a eleição de governos municipais democráticos que testaram políticas sociais participativas, as lutas sociais pela mudança dos marcos legais que regulam o uso e a ocupação do solo lograram apresentar avanços no fim do século XX. Nesse contexto, não se pode negar que a Constituição Federal de 1988 e o Estatuto da Cidade de 2000 constituem paradigmas inovadores e modernizantes, que pavimentaram o acesso para a criação da Lei de Mobilidade Urbana (Lei 12.587/2012).

\subsection{LEI DE MOBILIDADE URBANA (LEI 12.587/2012)}

A Lei 12.587/2012 teve como embrião o Projeto de Lei 694/1995, proposto pelo deputado federal Alberto Goldman. Entretanto, este dispunha apenas sobre as diretrizes para o transporte coletivo. Ainda na década de 1990, foram apensados ao PL 694/1995 o PL 1.974/1996, que tratava da prestação de serviços de transporte rodoviário coletivo de passageiros sobre o regime de concessão ou permissão, e o PL 2.234/1999, que tratava do sistema integrado de transporte coletivo urbano. (BRASIL, 2015).

Para Vasconcelos (2001), a mobilidade urbana tem a ver com a ideia de acessibilidade (de macro e microacessibilidade) e, consequentemente, com direito à locomoção, pois é a falta da acessibilidade que faz emergir o direito à locomoção, que também é afetado em grau distinto de intensidade pela falta de mobilidade. Nesse conceito, Vasconcelos define:

\footnotetext{
A macroacessibilidade tem relação direta com a abrangência espacial do sistema viário e dos sistemas de transporte, estando ligado às ações empreendidas no nível do planejamento de transporte, que define a constituição básica destes sistemas. (...) Enquanto que a microacessibilidade, refere-se à facilidade relativa de ter direito aos veículos ou destinos desejados, por exemplo, condição de estacionamento e de acesso ao ponto de ônibus. (VASCONCELOS, 2001, p. 91)
}

O marco institucional do início da participação federal no setor de transporte urbano foi a edição da Lei 6.261/1975, que cria a Empresa Brasileira de Transportes Urbanos (EBTU) e institui o Sistema Nacional de Transportes Urbanos (SNTU). Para Vasconcelos (2001), o governo federal passou a assumir a corresponsabilidade pelos transportes urbanos, em particular na formulação de políticas e diretrizes, além de apoio técnico e financeiro. 
Segundo Fagnani \& Cadaval (1988, p.44), a atuação do governo federal no âmbito municipal no início dos anos 1980 foi mais relevante em relação aos objetivos da política econômica. Essa atuação ocorreu como "instrumento de transformação da matriz energética, dado o segundo choque de petróleo, e da política monetária e cambial do governo no contexto de crise econômica".

\begin{abstract}
A montagem de um sistema institucional para apoiar o planejamento e financiamento dos transportes urbanos nas principais cidades brasileiras, tendo a EBTU como entidade-chave desse processo, trouxe consigo a emergência de inúmeros problemas de natureza legal e institucional. Por outro lado, havia dificuldades também ligadas à inadequação das estruturas institucionais e legais de natureza local, para apoio às atividades da EBTU. Em outras palavras, não havia, na verdade, uma política nacional com diretrizes e linhas de ação definidas para orientar a ação da própria EBTU. (BARAT, 1986, p. 17)
\end{abstract}

Ao longo do tempo, inúmeras tentativas de descentralização para nível local foram feitas, contudo, o processo realmente se intensificou com o Projeto de Lei 694/1995, que deu causa à Lei de Mobilidade. Após uma década e meia de tramitação no Congresso Nacional, a Lei Federal 12.587 foi promulgada em 03/01/2012, com 27 artigos, dividida em sete capítulos. Os dois primeiros artigos da lei informam:

Art. $1^{\circ}$ A Política Nacional de Mobilidade Urbana é instrumento da política de desenvolvimento urbano de que trata o inciso XX do art. 21 e o art. 182 da Constituição Federal, objetivando a integração entre os diferentes modos de transporte e a melhoria da acessibilidade e mobilidade das pessoas e cargas no território do Município.

Parágrafo único. A Política Nacional a que se refere o caput deve atender ao previsto no inciso VII do art. $2^{\circ}$ e no $\S 2^{\circ}$ do art. 40 da Lei $N^{\circ} 10.257 / 2001$.

Art. $2^{\circ}$. A Política Nacional de Mobilidade Urbana tem por objetivo contribuir para o acesso universal à cidade, o fomento e a concretização das condições que contribuam para a efetivação dos princípios, objetivos e diretrizes da política de desenvolvimento urbano, por meio do planejamento e da gestão democrática do Sistema Nacional de Mobilidade Urbana.

De acordo com o art. $3^{\circ}$ da Lei 12.587/2012, o SNMU é o conjunto organizado e coordenado dos modos de transporte, de serviços e de infraestruturas que garante os deslocamentos de pessoas e cargas no território do município. 
Quadro 2.5 Artigo $3^{\circ}$ da Lei $12.587 / 2012$

\begin{tabular}{|c|c|c|c|}
\hline Art. $3^{\circ}$ & \multicolumn{3}{|c|}{$\begin{array}{l}\text { O Sistema Nacional de Mobilidade Urbana é o conjunto organizado e e } \\
\text { coordenado dos modos de transporte, de serviços e de infraestruturas que } \\
\text { garante os deslocamentos de pessoas e cargas no território do Município. }\end{array}$} \\
\hline \multirow{2}{*}{$\S 1^{\circ}$} & \multirow{2}{*}{ Modos do transporte urbano } & \multicolumn{2}{|l|}{ I- motorizado } \\
\hline & & \multicolumn{2}{|l|}{ II- não motorizado } \\
\hline \multirow{6}{*}{$\S 2^{\circ}$} & \multirow{6}{*}{$\begin{array}{l}\text { Os serviços de transporte } \\
\text { urbano são classificados: }\end{array}$} & \multirow[b]{2}{*}{ I - quanto ao objeto: } & a) de passageiros; \\
\hline & & & b) de cargas \\
\hline & & \multirow{2}{*}{$\begin{array}{l}\text { II - quanto à } \\
\text { característica do } \\
\text { serviço: }\end{array}$} & a) coletivo; \\
\hline & & & b) individual; \\
\hline & & \multirow{2}{*}{$\begin{array}{l}\text { III - quanto à natureza } \\
\text { do serviço }\end{array}$} & a) público; \\
\hline & & & b) privado. \\
\hline \multirow{7}{*}{$\S 3^{\circ}$} & \multirow{7}{*}{$\begin{array}{l}\text { São infraestruturas de } \\
\text { mobilidade urbana: }\end{array}$} & \multicolumn{2}{|c|}{$\begin{array}{l}\text { I - vias e demais logradouros públicos, inclusive } \\
\text { metroferrovias, hidrovias e ciclovias; }\end{array}$} \\
\hline & & \multicolumn{2}{|l|}{ II - estacionamentos; } \\
\hline & & \multicolumn{2}{|c|}{ III - terminais, estações e demais conexões; } \\
\hline & & \multicolumn{2}{|c|}{$\begin{array}{l}\text { IV - pontos para embarque e desembarque de } \\
\text { passageiros e cargas; }\end{array}$} \\
\hline & & \multicolumn{2}{|c|}{ V - sinalização viária e de trânsito; } \\
\hline & & \multicolumn{2}{|c|}{ VI - equipamentos e instalações; e } \\
\hline & & \multicolumn{2}{|c|}{$\begin{array}{l}\text { VII - instrumentos de controle, fiscalização, } \\
\text { arrecadação de taxas e tarifas e difusão de } \\
\text { informações. }\end{array}$} \\
\hline
\end{tabular}

Fonte: Lei $12.587 / 2012$

$\mathrm{O}$ artigo $5^{\circ}$ da Lei de Mobilidade destaca os princípios da mobilidade urbana, indicando à sociedade quais são os fundamentos importantes que rege a política pública em questão. Bem como sinaliza para a sociedade em geral os princípios estratégicos contidos na lei. $\mathrm{O}$ artigo inicia dando ênfase na acessibilidade universal, que é generalidade do acesso aos modais, norteando todas as políticas do assunto como imposição da democratização de oportunidades.

Quadro 2.6 Artigo $5^{\circ}$ da Lei 12.587/2012

Art. $^{\circ} \quad$ A Política Nacional de Mobilidade Urbana está fundamentada nos seguintes princípios:

I $\quad$ Acessibilidade universal; 


\begin{tabular}{|c|c|}
\hline II & $\begin{array}{l}\text { Desenvolvimento sustentável das cidades, nas dimensões socioeconômicas e } \\
\text { ambientais; }\end{array}$ \\
\hline III & Equidade no acesso dos cidadãos ao transporte público coletivo; \\
\hline IV & Eficiência, eficácia e efetividade na prestação dos serviços de transporte urbano; \\
\hline $\mathrm{V}$ & $\begin{array}{l}\text { Gestão democrática e controle social do planejamento e avaliação da Política } \\
\text { Nacional de Mobilidade Urbana; }\end{array}$ \\
\hline VI & Segurança nos deslocamentos das pessoas; \\
\hline VII & $\begin{array}{l}\text { Justa distribuição dos benefícios e ônus decorrentes do uso dos diferentes modos e } \\
\text { serviços; }\end{array}$ \\
\hline VIII & Equidade no uso do espaço público de circulação, vias e logradouros; e \\
\hline IX & Eficiência, eficácia e efetividade na circulação urbana. \\
\hline
\end{tabular}

Fonte: Lei $12.587 / 2012$

As diretrizes que traçam os rumos da política e mobilidade devem ser amparadas por meio de um processo robusto de integração de todas as políticas de desenvolvimento urbano com o planejamento estratégico. A incorporação de diretrizes para o planejamento, a gestão e a avaliação dos sistemas de mobilidade urbana são aprimoramentos trazidos na própria Lei de Mobilidade.

Vale destacar o artigo $6^{\circ}$ da mesma lei, que versa sobre custos ambientais e energias renováveis, abrangendo o compromisso dos gestores aos princípios da prevenção, precaução e exploração sustentável do ambiente da mobilidade. Dessa forma, fica subentendido na lei o imperativo de realização prévia de estudo de impacto ambiental, o que acataria constitucionalmente dispositivo evidentes no artigo 225 da Constituição Federal. 
Quadro 2.7 Artigo 6 da Lei 12.587/2012

\begin{tabular}{|c|c|}
\hline Art. $6^{\circ}$ & $\begin{array}{c}\text { A Política Nacional de Mobilidade Urbana é orientada pelas seguintes } \\
\text { diretrizes: }\end{array}$ \\
\hline I & $\begin{array}{l}\text { Integração com a política de desenvolvimento urbano e respectivas políticas } \\
\text { setoriais de habitação, saneamento básico, planejamento e gestão do uso do solo no } \\
\text { âmbito dos entes federativos; }\end{array}$ \\
\hline II & $\begin{array}{l}\text { Prioridade dos modos de transportes não motorizados sobre os motorizados e dos } \\
\text { serviços de transporte público coletivo sobre o transporte individual motorizado; }\end{array}$ \\
\hline III & Integração entre os modos e serviços de transporte urbano; \\
\hline IV & $\begin{array}{l}\text { Mitigação dos custos ambientais, sociais e econômicos dos deslocamentos de } \\
\text { pessoas e cargas na cidade; }\end{array}$ \\
\hline V & $\begin{array}{l}\text { Incentivo ao desenvolvimento científico-tecnológico e ao uso de energias } \\
\text { renováveis e menos poluentes; }\end{array}$ \\
\hline VI & $\begin{array}{l}\text { Priorização de projetos de transporte público coletivo estruturadores do território e } \\
\text { indutores do desenvolvimento urbano integrado; e }\end{array}$ \\
\hline VII & $\begin{array}{l}\text { Integração entre as cidades gêmeas localizadas na faixa de fronteira com outros } \\
\text { países sobre a linha divisória internacional. }\end{array}$ \\
\hline
\end{tabular}

Fonte: Lei 12.587/2012

$\mathrm{O}$ artigo $7^{\circ}$ da lei aponta os objetivos que devem ser perseguidos na PNMU. O objetivo se traduz em metas a serem alcançadas por meio da confecção de planos de ações na busca dos propósitos da implementação da Lei de Mobilidade. Embora alguns termos dos artigos $5^{\circ}$ e $6^{\circ}$ reforcem esse dispositivo, eles reforçam o arcabouço estratégico definido pela Lei. Sendo que essas metas surgem da fonte primária de direitos e garantias fundamentais (CF 1988), que dá amparo legal à Lei 12.587/2012. 
Quadro 2.8 Artigo $7^{\circ}$ da Lei $12.587 / 2012$

\begin{tabular}{|c|l|}
\hline Art. $7^{\circ}$ & \multicolumn{1}{|c|}{ A Política Nacional de Mobilidade Urbana possui os seguintes objetivos: } \\
\hline I & Reduzir as desigualdades e promover a inclusão social; \\
\hline II & Promover o acesso aos serviços básicos e equipamentos sociais; \\
\hline III & $\begin{array}{l}\text { Proporcionar melhoria nas condições urbanas da população no que se refere à } \\
\text { acessibilidade e à mobilidade; }\end{array}$ \\
\hline IV & $\begin{array}{l}\text { Promover o desenvolvimento sustentável com a mitigação dos custos ambientais } \\
\text { e socioeconômicos dos deslocamentos de pessoas e cargas nas cidades; e }\end{array}$ \\
\hline V & $\begin{array}{l}\text { Consolidar a gestão democrática como instrumento e garantia da construção } \\
\text { contínua do aprimoramento da mobilidade urbana. }\end{array}$ \\
\hline
\end{tabular}

Fonte: Lei 12.587/2012

Dentro da linha de planejamento estratégico concebido pela Lei, faz-se necessária a criação de planos de mobilidade que possam estabelecer objetivos claros de curto, médio e longo prazos. Também deve indicar as fontes de financiamento e os mecanismos técnicos necessários à implantação e à execução dos projetos, conforme é definido pelo Caderno de Instrução denominado PlanMob. (BRASIL, 2015)

O PlanMob foi criado pelo Ministério das Cidades e configura-se num caderno de referência elaborado pelo corpo técnico deste ministério e por equipes de profissionais contratados pela Semob, com o objetivo de orientar os municípios e estados na construção de seus respectivos Planos de Mobilidade Urbana. (BRASIL, 2015)

O público-alvo deste caderno constitui-se de técnicos e gestores públicos que atuam diretamente com as questões de mobilidade urbana nas administrações municipais, bem como de lideranças políticas e de movimentos sociais que atuam nas questões urbanas. O conteúdo do caderno abrange aspectos diversos da mobilidade urbana que devem ser considerados por todos os municípios do País. (BRASIL, 2015, p.14)

O Caderno de Referência é um valioso instrumento para a criação dos planos de mobilidade, pois foi planejado de forma a fornecer conceitos, fundamentos e procedimentos básicos para a 
aplicação da PNMU. Além disso, contém processos derivados da gestão de projetos, como ponto importante a ser observado na construção de planos de mobilidade. De forma geral, o PlanMob se apresenta como um instrumento complexo aos municípios que possuem reduzida capacitação técnica, o que gera um grande desafio à gestão local.

A Lei de Mobilidade Urbana inova quando determina os conteúdos mínimos obrigatórios para um plano de mobilidade, objetivando atender às disposições contidas na Lei 12.587/2012, além de outros aspectos fundamentais que envolvem sua capacidade técnica e financeira, diante do conjunto de necessidades levantadas pela administração local junto à sociedade.

Quadro 2.9 Artigo 24 da Lei $12.587 / 2012$

\begin{tabular}{|c|c|}
\hline Art. 24 & $\begin{array}{l}\text { O Plano de Mobilidade Urbana é o instrumento de efetivação da Política } \\
\text { Nacional de Mobilidade Urbana e deverá contemplar os princípios, os } \\
\text { objetivos e as diretrizes desta Lei, bem como: }\end{array}$ \\
\hline I & Os serviços de transporte público coletivo; \\
\hline II & A circulação viária; \\
\hline III & As infraestruturas do sistema de mobilidade urbana; \\
\hline IV & A acessibilidade para pessoas com deficiência e restrição de mobilidade; \\
\hline $\mathrm{V}$ & $\begin{array}{l}\text { A integração dos modos de transporte público e destes com os privados e os não } \\
\text { motorizados; }\end{array}$ \\
\hline VI & A operação e o disciplinamento do transporte de carga na infraestrutura viária; \\
\hline VII & Os polos geradores de viagens; \\
\hline VIII & As áreas de estacionamentos públicos e privados, gratuitos ou onerosos; \\
\hline IX & As áreas e horários de acesso e circulação restrita ou controlada; \\
\hline $\mathrm{X}$ & $\begin{array}{l}\text { Os mecanismos e instrumentos de financiamento do transporte público coletivo e } \\
\text { da infraestrutura de mobilidade urbana; e }\end{array}$ \\
\hline
\end{tabular}


XI A sistemática de avaliação, revisão e atualização periódica do Plano de Mobilidade Urbana em prazo não superior a $10(\mathrm{dez})$ anos.

Fonte: Lei $12.587 / 2012$

O plano de mobilidade deve balizar os mecanismos de monitoramento e avaliação sistemáticos dos objetivos estabelecidos em projeto, bem como determinar os indicadores de desempenho a serem empregados. Destarte, o plano de mobilidade será avaliado dentro de um processo de julgamento que determinará sua eficácia diante de parâmetros estabelecidos pela Lei de Mobilidade e dentro dos objetivos instituídos pelo planejamento. (BRASIL, 2015)

Todos os municípios acima de 20 mil habitantes devem elaborar seus planos de mobilidade urbana, que deverão ser revistos a cada dez anos. O Plano de Mobilidade Urbana é o instrumento de efetivação da política. Até então, a Lei no 10.257 de 2001 (Estatuto da Cidade) definia que a elaboração de um plano de transporte urbano era obrigatória apenas para aqueles municípios com mais de quinhentos mil habitantes (IPEA, 2012, p.13). Além disso, nos municípios sem sistema de transporte público coletivo ou individual, o plano de mobilidade deverá ter foco no transporte não motorizado e no planejamento da infraestrutura urbana destinada aos deslocamentos a pé e por bicicleta, de acordo com a legislação vigente.

A elaboração do plano de mobilidade implica levantar as necessidades e os meios de deslocamentos intra-urbanos do município, e até mesmo nos deslocamentos que ocorrem fora do seu perímetro, mas que têm efeito na circulação municipal. Os municípios, por sua vez, devem planejar, executar e avaliar a PMU, promover a regulamentação adequada, prestar os serviços de transporte público coletivo urbano (caráter essencial) além de capacitar pessoas e desenvolver instituições vinculadas à política de mobilidade urbana local (Brasil, 2015).

A construção do plano de mobilidade deverá agregar a participação dos conselhos de transportes de cada municipalidade, de forma a congregar soluções que atendam às necessidades coletivas e dentro das diretrizes da PNMU. Os projetos devem estar voltados ao tamanho e às particularidades de cada localidade, adequados às demandas locais da população. (BRASIL, 2015). Afigura 2.3 evidencia a faixa populacional dos Municípios que estão sob a exigência da Lei de Mobilidade. 


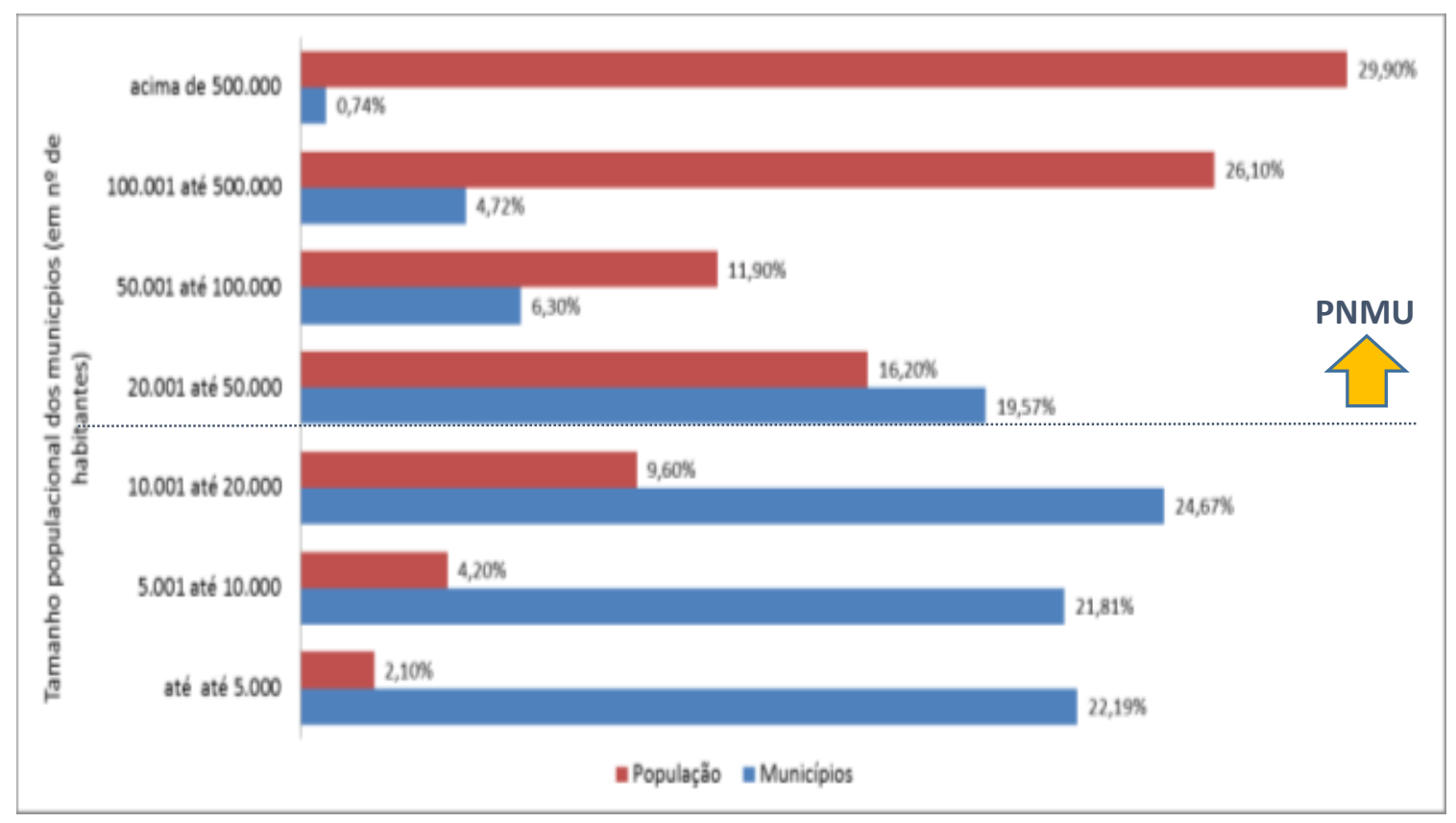

Figura 2.3 População dos municípios por grupos de tamanho populacional. Adaptado IBGE (2012).

Municípios grandes (acima de 500 mil habitantes) podem endereçar seus projetos ao transporte público coletivo, enquanto que munícipios pequenos (entre 20 e 100 mil habitantes) podem trabalhar de forma mais específica nos deslocamentos não motorizados. A PMU deve ser trabalhada em cima da necessidade de cada Município e a análise de uma matriz de divisão modal pode ser um bom instrumento para direcionar os planos de mobilidade. A figura 2.4. registra a divisão modal por porte de Municípios no Brasil, elencando características por faixa.

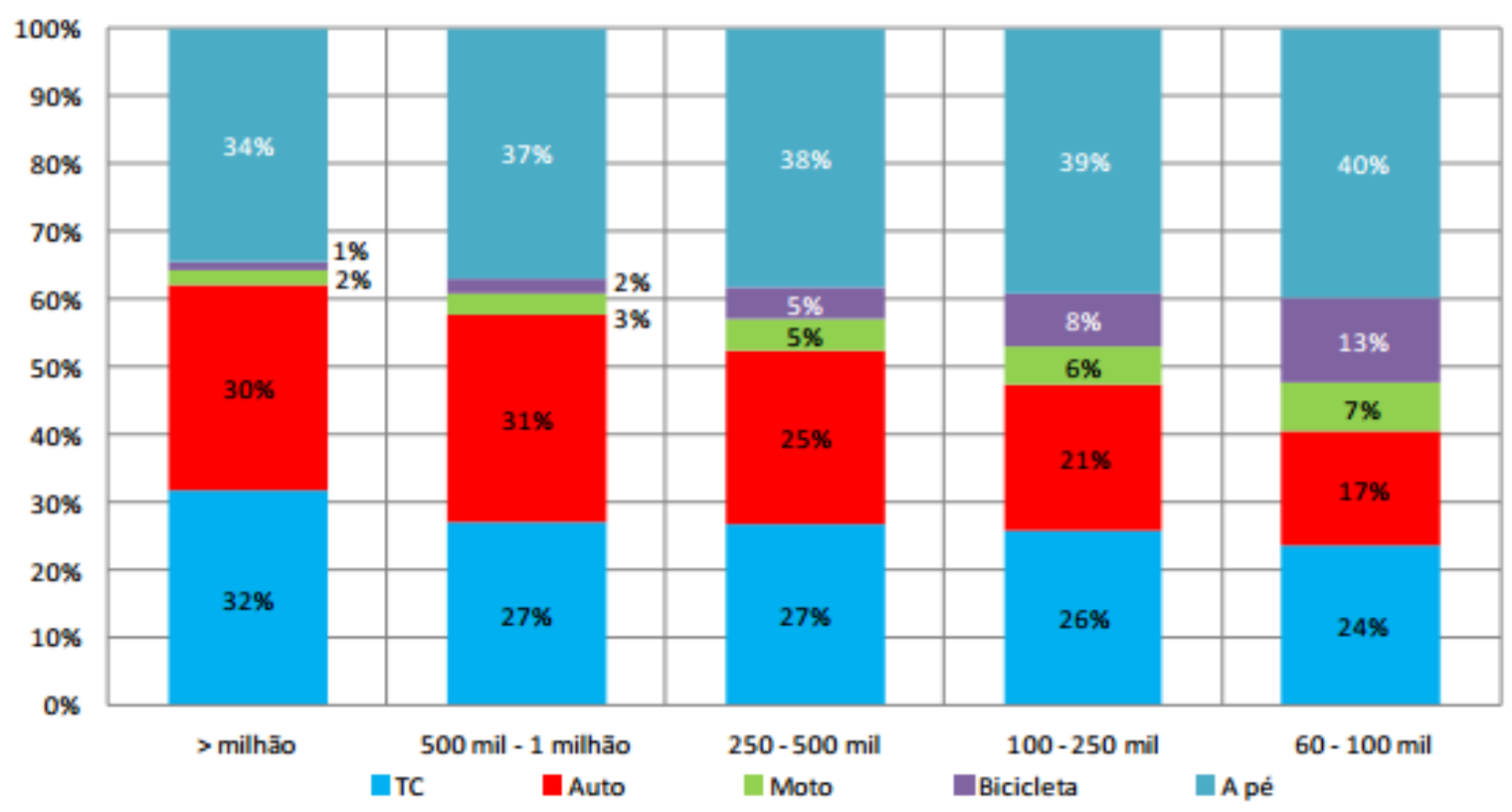

Figura 2.4 - Gráfico da divisão modal por porte de município. Adaptado ANTP (2012) 


\subsection{PARTICIPAÇÃO SOCIAL}

O êxito da formulação de políticas exige que tanto os formuladores de políticas como o público debatam e redefinam continuamente limites, distribuição de encargos e benefícios e examinem as consequências tendo em vista valores e compromissos fundamentais. Tais esforços de políticas são, em última instância, processos políticos bem sucedidos a que se dedicam todas as partes relevantes. (BRYNER, 1987)

Segundo Maricato (2006), a participação da sociedade civil, por meio da representação de interesses diversos, tem o papel de garantir, em primeiro lugar, a inclusão, no debate democrático, daqueles que estiveram historicamente alijados das discussões sobre os rumos do país; e, em segundo lugar, fazer aflorar os conflitos de interesses e dar a eles um tratamento democrático, o que é inédito em nossa sociedade, na escala considerada.

Oliveira (2002, p.28), cita que "a sociedade civil inclui a cidade, mas não se esgota nela, pois acontece muitas vezes que uma relação de forças estranha ao local pode influir poderosamente nele, exatamente por que a sociedade civil em sentido amplo exige um padrão de moralidade pública que desborda os limites locais". Nesse contexto, complementa Milani (2008, p.4), “a necessidade de se considerar a participação dos cidadãos no palco da construção e gestão das políticas públicas locais foi uma saída ao descontentamento geral que permeia a política do ente federativo distante da realidade local”.

A Constituição de 1988 adotou novas atribuições para as organizações da sociedade civil dentro do sistema político brasileiro, destacando o seu papel protagonista na condução da "coisa pública". É por essas razões, entre outras, que a Carta Magna foi batizada de "Constituição Cidadã". Nesse sentido, o Conselho de Políticas Públicas corresponde a um importante mecanismos de deliberação coletiva, criado a partir das diretrizes constitucionais de participação cidadã nas políticas públicas do Estado brasileiro (CICONELLO, 2008).

A participação pública está presente em vários dispositivos legais da CF/1988. "Os novos mecanismos participativos incluídos na governança local se baseiam no engajamento popular como um recurso produtivo central: a participação dos cidadãos provê informações e diagnósticos sobre os problemas públicos, geram conhecimentos e subsídios à elaboração de estratégias de resolução dos problemas e conflitos envolvidos. A qualidade da participação pode 
ser mensurada pelo grau de informação ou (de desinformação) contido nas opiniões dos participantes" (GOHN, 2002, p.20).

Embora a figura de um conselho não fosse uma novidade no Estado brasileiro, o espaço dado a essa representação após a Constituição de 1988 foi uma verdadeira revolução institucional no Brasil. Uma das primeiras políticas públicas a ser inteiramente reconfigurada dentro desse novo referencial de participação e de descentralização foi a política de saúde. Em cada município, foi implantado um Conselho de Saúde, de caráter deliberativo e permanente, como forma de participação obrigatória.

Os chamados Conselhos de Políticas Públicas foram criados com o objetivo de operacionalizar os ideais participativos presentes na Constituição Federal, permitindo à população brasileira um maior acesso aos espaços de formulação, implementação e controle social das políticas públicas. Em vez de as decisões governamentais ficarem restritas aos membros do Poder Executivo e aos gestores públicos, elas passaram a ser compartilhadas com a sociedade civil.

"Para que os conselhos de gestão possam se constituir em canais democráticos de interação entre governo e sociedade, depende-se da sua efetividade, no sentido da sua capacidade de funcionar enquanto uma arena de debates, gestão de conflitos e construção de consensos, e tomar decisões e torná-las efetivas no que diz respeito às políticas públicas”. (MARICATO, 2006, p.14)

O Decreto 5.031/2004 regulamentou o Conselho das Cidades. Segundo Maricato (2006), no primeiro artigo desse decreto, o governo estabeleceu que o Conselho das Cidades é um órgão colegiado de natureza deliberativa e consultiva, integrante da estrutura do Ministério das Cidades, tendo por finalidade propor diretrizes para a formulação e implementação da política nacional de desenvolvimento urbano, bem como acompanhar e avaliar a sua execução, conforme disposto no Estatuto da Cidade.

No campo da política pública de transporte, por conta de tantos desafios complexos a serem enfrentados pelos gestores para atendimento das demandas de transporte e mobilidade, é necessário que seja dado conhecimento e que seja ampliada a discussão dos problemas junto à população. Segundo o art. 15 da Lei de Mobilidade Urbana, a participação da sociedade civil no planejamento, fiscalização e avaliação da PNMU deverá ser assegurada pelos instrumentos do Quadro 2.10. 


\begin{tabular}{|c|c|}
\hline Art. 15 & $\begin{array}{c}\text { A participação da sociedade civil no planejamento, fiscalização e avaliação } \\
\text { da Política Nacional de Mobilidade Urbana deverá ser assegurada pelos } \\
\text { seguintes instrumentos: }\end{array}$ \\
\hline I & $\begin{array}{l}\text { Órgãos colegiados com a participação de representantes do Poder Executivo, da } \\
\text { sociedade civil e dos operadores dos serviços; }\end{array}$ \\
\hline II & $\begin{array}{l}\text { Ouvidorias nas instituições responsáveis pela gestão do Sistema Nacional de } \\
\text { Mobilidade Urbana ou nos órgãos com atribuições análogas; }\end{array}$ \\
\hline III & Audiências e consultas públicas; e \\
\hline IV & $\begin{array}{l}\text { Procedimentos sistemáticos de comunicação, de avaliação da satisfação dos } \\
\text { cidadãos e dos usuários e de prestação de contas públicas. }\end{array}$ \\
\hline
\end{tabular}

Fonte: Lei 12.587/2012

De forma evidente, um dos destaques da Lei de Mobilidade Urbana é a promoção da gestão democrática e dos direitos dos usuários, ao conferir voz ativa aos cidadãos no processo de construção de políticas por meio dos Conselhos de Transportes. Segundo a Lei de Mobilidade, é mandatória a discussão dos planos de mobilidade junto a um conselho local composto de representantes de vários setores da sociedade, para que possam deliberar sobre as prioridades do município. Contudo, há ainda um vácuo de mobilização para estruturar os Conselhos de Política Urbana, conforme apresentado no Quadro 2.11. 
Quadro 2.11 Municípios com Conselho Municipal de Política Urbana ou similar

\begin{tabular}{|c|c|c|c|}
\hline \multirow{2}{*}{$\begin{array}{c}\text { Municípios por } \\
\text { tamanho da população }\end{array}$} & Total & $\begin{array}{c}\text { Municípios } \\
\text { Com Conselho } \\
\text { Municipal de } \\
\text { Política Urbana }\end{array}$ & $\begin{array}{c}\text { Realizou } \\
\text { reunião nos } \\
\text { últimos 12 } \\
\text { meses }\end{array}$ \\
\cline { 2 - 3 } & & Total & 888 \\
\hline Brasil & 5.565 & 1.231 & 95 \\
\hline Até 5.000 & 1.298 & 134 & 89 \\
\hline De 5.001 a 10.000 & 1.210 & 131 & 156 \\
\hline De 10.001 a 20.000 & 1.388 & 224 & 239 \\
\hline De 20.001 a 50.000 & 1.054 & 352 & 131 \\
\hline De 50.001 a 100.000 & 327 & 170 & 149 \\
\hline De 100.001 a 500.000 & 250 & 187 & 29 \\
\hline Mais de 500.000 & 38 & 33 & \\
\hline
\end{tabular}

Fonte: IBGE (2012)

Segundo Arretche (2002, p. 339),

a dificuldade de definir o que seja bom desempenho dos conselhos, a dificuldade de construir indicadores úteis e confiáveis para comparar uma amostra razoável de casos e a enorme quantidade de conselhos hoje existentes estão entre os principais obstáculos para avaliarmos o impacto real dos conselhos. Entretanto, o otimismo quanto às possibilidades potenciais dessas instituições deve ser examinado sob o ângulo das condições que favorecem seu funcionamento efetivo. (ARRETCHE, 2002, p.340)

\subsection{TÓPICOS CONCLUSIVOS}

Vale destacar que o trabalho não objetiva discutir com profundidade os temas citados, apenas elencar o que é importante para a construção de uma metodologia capaz de aferir a estratégia política no campo de aplicação da Lei de Mobilidade na esfera municipal. No entanto, alguns pontos são conclusivos neste capítulo.

A tomada de decisão não é um estágio isolado e também não é sinônimo de todo o processo de decisão política, mas tem um peso grande na aplicação de políticas públicas. Haja vista o caráter de intenção por parte dos atores envolvidos no sentido de empreender ou não alguma ação como uma lei ou regulamento. Além disso, as escolhas traduzem a estratégia usada na materialização 
da vontade ou de vontades. Destaca-se, nessa etapa conclusiva, que a tomada de decisão sinaliza se o status quo deve ser mantido ou mudado.

Em importante constatação, coloca-se de forma evidente o atraso da criação de políticas públicas de mobilidade. Mesmo sob a égide da Constituição de 1988, a Lei 12.587/2012 só foi concretizada 24 anos depois da promulgação da última Carta Política do Brasil. Nesse contexto, os desafios são exponencialmente maiores para a efetivação da PNMU.

Destaca-se também o processo de descentralização da PMU local (municipal), promovendo um processo desafiador frente ao conjunto de exigências que permeiam a aplicabilidade da lei. Nesse sentido, o que se denota é uma grande exigência da capacidade de gestão dos municípios para pôr em pratica seus planos de mobilidade.

Por último, destaca-se a importância da participação social ao processo de discussão e aplicação dos planos de mobilidade. A sociedade possui poderes para interferir na agenda do governo e definir prioridades e prerrogativas nas ações políticas da gestão local. No entanto, para que essa agenda seja justa, é necessário que seja viabilizado o acesso a informações e decisões, por meio de um processo de gestão transparente na discussão das políticas públicas do município. 


\section{GESTÃO MUNICIPAL DA MOBILIDADE}

O presente capítulo tem o compromisso de estabelecer um entendimento de tópicos importantes do universo da gestão pública. A introdução de autores relevantes ao contexto deste trabalho enriquece o processo de desenvolvimento sobre a importância da política estratégica em meio à aplicação de políticas públicas. Nesse sentido, o capítulo oferece o entendimento de modelos e ferramentas de gestão, que estão disponíveis ao universo da administração pública, mesmo estando ela inserida em ambiente demasiadamente burocrático.

O capítulo aponta conceitos importantes de gestão pública, gestão de projetos e gestão estratégica, buscando articular tais conceitos com o propósito do trabalho. Nesse contexto, busca-se alinhavar os elementos capazes de organizar e fortalecer o processo de tomada de decisão em âmbito municipal, necessários para atender as premissas do PNMU em âmbito local.

\subsection{GESTÃo PÚBLICA}

As relações trianguladas entre políticos, gestores e cidadão são múltiplas e complexas. $\mathrm{O}$ trabalho não tem a pretensão de entrar com profundidade nesse assunto. Mas é importante destacar a relação entre política e administração, sendo que o termo "administração" é visto aqui como gestão da administração pública, dentro de um contexto burocrático. De acordo com Weber (1999, p.217), “a estrutura burocrática vai de mãos dadas com a concentração dos meios materiais de administração nas mãos do senhor”.

Segundo Bryner (1987), o principal desafio enfrentado pelos administradores públicos é aprender como trabalhar de maneira mais eficaz em um ambiente político de modo a promover forte participação democrática e envolver ampla variedade na descoberta e implementação de soluções que resolvam ou pelo menos melhorem problemas públicos. Nesse contexto, a principal tarefa das organizações públicas é implementar as políticas aprovadas pelos governos.

Para Weber (1999, p.225), “tendencialmente, a administração burocrática é sempre uma administração que exclui o público. A burocracia oculta, na medida do possível, o seu saber e o seu fazer da crítica". Por outro lado, Weber (1999, p.232), cita que:

a burocracia aspira, por toda parte, ao desenvolvimento de uma espécie de "direito ao cargo", mediante a criação de um procedimento disciplinar ordenado e a eliminação do poder totalmente arbitrário do "superior" sobre o funcionário, enquanto procura assegurar a posição deste, sua ascensão regular, seu sustento na velhice. Encontra apoio para isso na disposição "democrática dos dominados". 
Quadro 3.1- Conceitos e definições de gestão pública.

\begin{tabular}{|c|c|}
\hline Autor & Definição \\
\hline Moore (1984) & $\begin{array}{l}\text { A essência da gestão pública é "conhecer e implementar políticas } \\
\text { públicas que realizem o potencial de um dado cenário político e } \\
\text { institucional", potencial esse que ele posteriormente chamou "valor } \\
\text { público". (MOORE, 1984, apud LYNN, 2010, p. 37) }\end{array}$ \\
\hline Fayol (1930) & $\begin{array}{l}\text { "É importante não confundir administração com gestão. Gerir [...] é } \\
\text { conduzir uma organização para o melhor uso possível [...]dos recursos } \\
\text { à sua disposição [...] assegurar o funcionamento das suas funções } \\
\text { essenciais. A administração representa apenas uma dessas funçes." } \\
\text { (FAYOL, } 1930 \text { apud LYNN, 2010, p. 35) }\end{array}$ \\
\hline $\begin{array}{l}\text { Ott, Hyde e Shaftitz } \\
\text { (1991) }\end{array}$ & $\begin{array}{l}\text { A gestão pública é um segmento importante do campo da } \\
\text { administração pública [...] A gestão pública enfoca a administração } \\
\text { pública como uma profissão e o gestor público como um praticante } \\
\text { dessa profissão. (OTT; HYDE; SHAFRITZ, 1991 apud LYNN, 2010, } \\
\text { p. 36) }\end{array}$ \\
\hline $\begin{array}{l}\text { Barry Bozeman } \\
\text { (1987) }\end{array}$ & $\begin{array}{l}\text { "Todas as organizações são públicas." (BARRY BOZEMAN, } 1987 \\
\text { apud LYNN, 2010, p. 39) }\end{array}$ \\
\hline White (1926) & $\begin{array}{l}\text { "O estudo da administração deve tomar como base a gestão em vez } \\
\text { dos fundamentos da lei." (WHITE, 1926, apud LYNN, 2010, p. 35) }\end{array}$ \\
\hline Weimer (1995) & $\begin{array}{l}\text { "A gestão pública como instituição observa as regras práticas, ou seja, } \\
\text { as restrições de fato ou as diretrizes do comportamento, que garantam } \\
\text { legitimidade no contexto de um regime constitucional." "Gestão } \\
\text { pública é estrutura, arte e instituição; gestão, gestor e prática } \\
\text { responsável." (WEIMER, 1995, apud LYNN, 2010, p. 34). }\end{array}$ \\
\hline
\end{tabular}

Fonte: Lynn (2010)

No entanto, políticos e gestores diferem nos modos de se relacionar com a sociedade, embora ambos sejam componentes críticos para a governança democrática. "Política", no contexto atual, é uma questão de representação, enquanto gestão refere-se a políticas de implementação e ao exercício do poder político e da aplicação das leis no contexto de políticas públicas. O que se vê na prática é que essas posições se confundem no processo da gestão pública, afetando a estratégia de condução de políticas públicas. Como exemplo citam-se as "promessas políticas" inviáveis no plano da implementação e da execução.

Cabe destacar que muitos aspectos da gestão pública permanecem inalterados há décadas. Concomitantemente, outros passaram por mudanças fundamentais. Nesse aspecto, pode-se observar a ênfase crescente do papel do gestor público como gerente, e a necessidade de aplicar ferramentas gerenciais familiares ao setor privado, que é um processo inevitável trazido naturalmente à luz do cotidiano. Outra importante mudança é o visível estreitamento da relação 
entre Estado e sociedade na entrega de serviços públicos. Esse fenômeno é visto de forma evidente no processo de descentralização de políticas públicas locais.

Seguindo a construção do raciocínio que embasa este trabalho, há de se destacar também o papel da burocracia no contexto da avaliação. Cabe enfatizar que o sentido da palavra burocracia é usado aqui como estruturas administrativas formais do setor público. Segundo Weber (1999, p.228), “a burocracia é um instrumento de precisão que pode colocar-se à disposição de interesses de dominação muito diversos, tanto puramente políticos ou econômicos quanto outros quaisquer."

Por outro lado, a ausência da gestão pública é uma ocorrência extrema e não desejada, mas a questão mais relevante é discutir o que acontece com um governo quando a gestão pública não é efetiva, ou eficiente ou ética. As várias formas de falha da administração têm suas consequências negativas para o governo e para a sociedade. Uma administração que não tenha ética ou que seja parasitária é a pior forma de falha. (CHAPMAN, 2000)

Guy Peters (1987) esclarece que o que separa o político eleito dos gestores da administração pública é importante. Segundo o autor, gestores públicos não podem ignorar os políticos, mas também devem assegurar a manutenção da posição correta destes nos governos. Administrar operações de larga escala, sejam elas públicas ou privadas, requer habilidades gerenciais e não há nada nos gabinetes políticos que garanta que os eleitos detenham essas capacidades.

\footnotetext{
Nossa concepção de "gestão pública" acrescenta a responsabilidade pelo estabelecimento de objetivos e o gerenciamento político às atribuições tradicionais da administração pública. (...) Nossa concepção de gestão pública acrescenta algumas funções executivas essenciais, tais como definir propósitos, manter a credibilidade dos supervisores, arregimentar autoridade e recursos e posicionar uma organização em um dado ambiente político, como componentes centrais do trabalho de um gestor público. (MOORE, 1984, p. 2-3)
}

Na visão de Moore (1984, p.3), a essência da gestão pública é “conceber e implementar políticas públicas que realizem o potencial de um dado cenário político e institucional", potencial esse que ele posteriormente chamou de valor público. Segundo Moore (2007, p.161), “valor público pode ser o que nós fazemos em prol das condições públicas que gostaríamos de habitar e o que podemos, coletivamente, concordar que gostaríamos de alcançar usando os poderes do Estado".

Entretanto, ao ressaltar o papel político-estratégico dos gestores públicos no âmbito de determinados cenários políticos e institucional, conceitos mais recentes de gestão pública têm demonstrado maior preocupação com as questões imediatas, pragmáticas dos gestores nos 
níveis executivos das organizações governamentais. Segundo Abrucio (2005), a profissionalização da burocracia de forma a permitir avaliações constantes por meio de metas e indicadores, semelhante ao ambiente privado, são ações que poderiam reduzir a interferência política no ambiente da gestão pública.

Sob essa perspectiva, um argumento em particular para distinguir entre administração e gestão, nos tempos atuais, merece exame mais aprofundado. "Aqueles que definem a administração pública em termos gerenciais", segundo Rosenbloomb (1998, p.16), “tendem a minimizar as distinções entre administração pública e privada". Nesse sentido, cabe destacar que o objeto do governo não costuma ser a obtenção do ganho, mas a promoção do bem-estar social. É baseado nessa afirmação que o trabalho se sustenta quando fala em gestão pública.

\subsection{GESTÃO DE PROJETOS E A TEORIA DOS STAKEHOLDERS}

Gestão de projetos surgiu como ciência a partir do século XX. No entanto, as técnicas de gestão de projetos não é algo novo como conhecimento e aplicação. Há evidências da prática empírica de gestão de projetos desde a construção das pirâmides do Egito. Contudo, passou a ser reconhecida como ferramenta de gestão nas mãos de Frederick Taylor e Henry Gantt, cuja aplicação de forma mais contundente se deu durante a Segunda Guerra Mundial, em projetos militares. Além disso, passou a atuar como disciplina em diferentes campos de aplicação, como as engenharias. Na década de 1960, nos Estados Unidos, foi criado o Project Management Institute (PMI), entidade sem fins lucrativos, responsável por editar normas e técnicas de gerenciamento de projetos.

Segundo Heldman (2006, p.12),

o gerenciamento de projetos significa aplicar habilidades, conhecimentos, bem como fundamentos e técnicas consagradas gerenciamento de projetos, aos métodos de realização do projeto, a fim de produzir os melhores resultados possíveis. Os projetos surgem em consequência de uma necessidade, e essa necessidade tem relação com as expectativas do cliente no tocante ao resultado final. (HELDMAN, 2006).

De acordo com Herrero Filho (2011, p.165),

o PMBOK (Project Management Body of Knowledge) deve ser considerado um guia de orientação, para as pessoas entenderem melhor qual é o significado de um projeto e como ele deve ser gerenciado. E, uma vez obtida essa compreensão, é possível perceber melhor o vínculo existente entre projetos, os objetivos estratégico e a execução da estratégia". 
Segundo o PMBOK (2013), projeto é um esforço temporário empreendido para criar um produto, serviço ou resultado exclusivo. A natureza temporária dos projetos indica que eles têm um início e um término definidos. O término é alcançado quando os objetivos do projeto são atingidos ou quando o projeto é encerrado porque os seus objetivos não serão ou não podem ser alcançados, ou quando a necessidade do projeto deixar de existir. A Fig. 3.1 traduz o conceito.

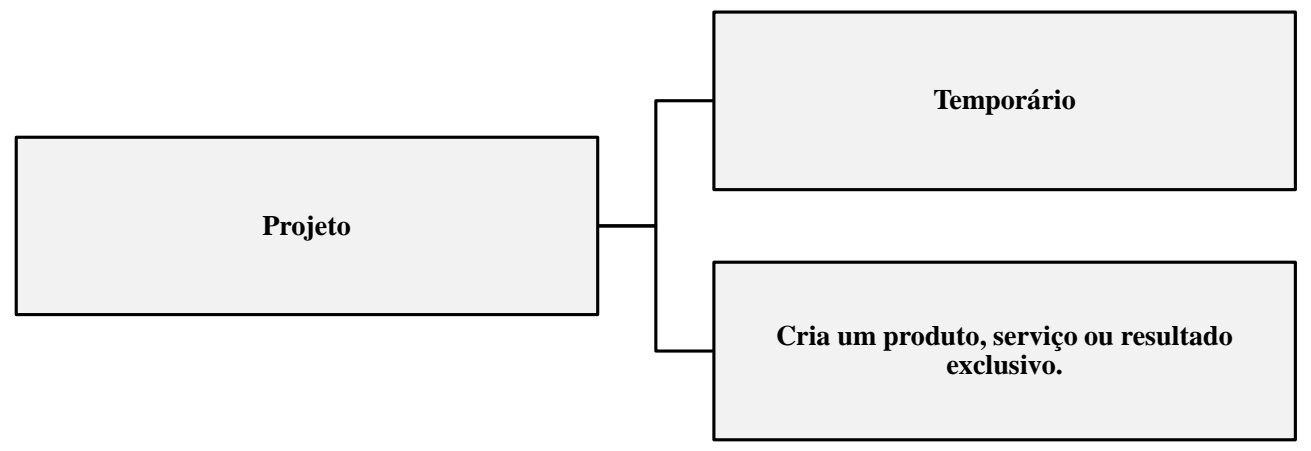

Figura 3.1 - Conceito de projeto. Adaptada PMBOK (2013)

De acordo com o PMBOK (2013), as atividades do projeto podem ser novas para os membros de uma equipe de projeto, o que poderá exigir um planejamento mais dedicado do que outro trabalho de rotina. Além disso, os projetos são empreendidos em todos os níveis organizacionais. Um projeto pode envolver uma única pessoa ou muitas pessoas, uma única organização ou múltiplas unidades organizacionais de múltiplas organizações. Um projeto pode criar:

- um produto que pode ser um componente de outro item, um aprimoramento de outro item, ou um item final;

- $\quad$ um serviço ou a capacidade de realizar um serviço;

- uma melhoria nas linhas de produtos e serviços;

- um resultado, como um produto ou documento.

O gerenciamento de projetos é a aplicação de conhecimento, habilidades, ferramentas e técnicas às atividades do projeto com o propósito de atender aos seus requisitos. O gerenciamento de projetos envolve a implementação de ações que visam planejar, executar e controlar diversas atividades para alcançar os objetivos especificados.

O gerenciamento de projetos é realizado por meio da aplicação e integração apropriadas dos 47 processos de gerenciamento de projetos, logicamente agrupados em cinco grupos de processos. 
Esses cinco grupos de processos segundo o Guia PMBOK (2013) são demonstrados por meio da Fig. 3.2.

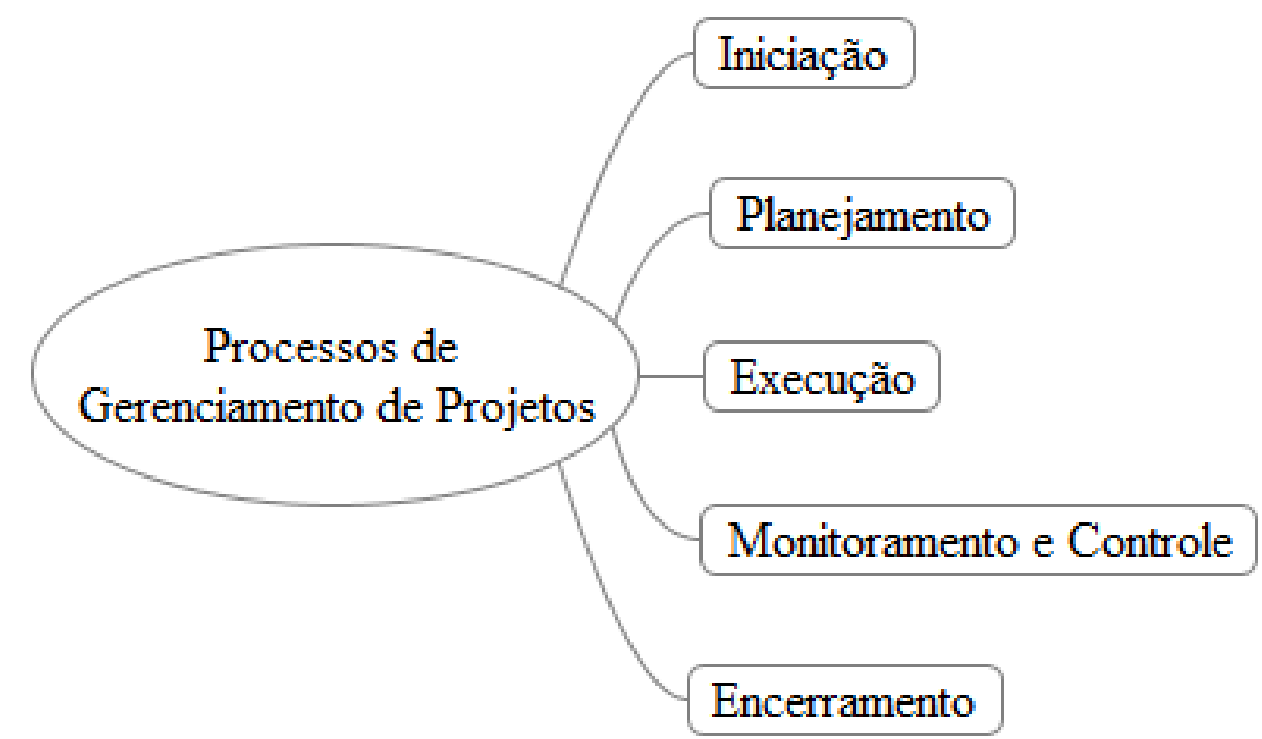

Figura 3.2 - Processos do Gerenciamento de Projetos. Adaptado PMBOK (2013)

Segundo o próprio PMBOK (2013), as cinco definições de processos do gerenciamento são detalhadas no Quadro 3.2.

Quadro 3.2- Definições de processos de gerenciamento.

\begin{tabular}{|c|l|}
\hline $\begin{array}{c}\text { Processos de } \\
\text { Iniciação }\end{array}$ & $\begin{array}{l}\text { São processos executados para definir um novo projeto ou uma nova } \\
\text { fase de um projeto existente por meio da obtenção de autorização para } \\
\text { iniciar o projeto ou fase. }\end{array}$ \\
\hline $\begin{array}{c}\text { Processos de } \\
\text { Planejamento }\end{array}$ & $\begin{array}{l}\text { São processos necessários para definir o escopo do projeto, refinar os } \\
\text { objetivos e definir a linha de ação necessária para alcançar os objetivos } \\
\text { para os quais o projeto foi criado. }\end{array}$ \\
\hline $\begin{array}{c}\text { Processos de } \\
\text { Execução }\end{array}$ & $\begin{array}{l}\text { São processos realizados para executar o trabalho definido no plano } \\
\text { de gerenciamento do projeto para satisfazer as especificações do } \\
\text { projeto. }\end{array}$ \\
\hline $\begin{array}{c}\text { Processos de } \\
\text { Conitoramento e }\end{array}$ & $\begin{array}{l}\text { São processos exigidos para acompanhar, analisar e controlar o } \\
\text { progresso e desempenho do projeto, identificar quaisquer áreas nas } \\
\text { quais serão necessárias mudanças no plano, e iniciar as mudanças } \\
\text { correspondentes. }\end{array}$ \\
\hline $\begin{array}{c}\text { Processos de } \\
\text { Encerramento }\end{array}$ & $\begin{array}{l}\text { São processos executados para finalizar todas as atividades de todos } \\
\text { os grupos de processos, visando encerrar formalmente o projeto ou } \\
\text { fase. }\end{array}$ \\
\hline
\end{tabular}

Fonte: PMBOK (2013) 
Conforme o Guia PMBOK (2013), as dez áreas de conhecimento em gerenciamento de projetos são definidas por seus requisitos e descritas em termos dos processos que a compõem, suas práticas, entradas, saídas, ferramentas e técnicas. São áreas de conhecimento em gerenciamento de projetos aquelas demonstradas pela Fig. 3.3.

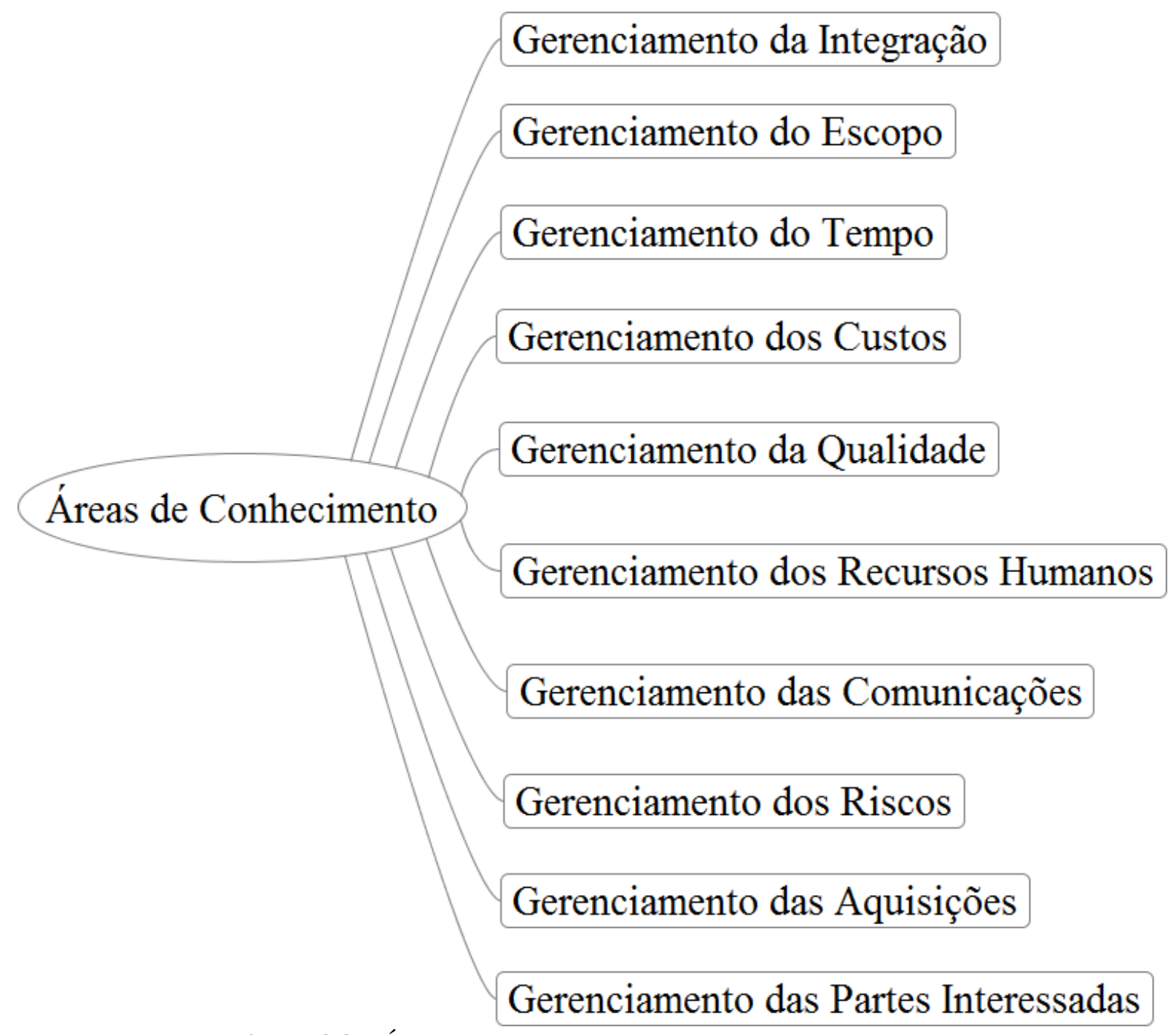

Figura 3.3 - Áreas do conhecimento. Adaptado PMBOK (2013)

De acordo com o guia PMBOK (2013), as definições das áreas do conhecimento do gerenciamento de projetos são detalhadas no Quadro 3.3.

Quadro 3.3 - Definições das áreas do conhecimento de projetos

\section{Gerenciamento da Integração}

Inclui os processos e atividades para identificar, definir, combinar, unificar e coordenar os vários processos e atividades dentro dos grupos de processos de gerenciamento do projeto. 


\begin{tabular}{|c|c|}
\hline $\begin{array}{l}\text { Gerenciamento do } \\
\text { Escopo }\end{array}$ & $\begin{array}{l}\text { Inclui os processos necessários para assegurar que o projeto abrange } \\
\text { todo o trabalho necessário, e apenas o necessário, para terminar o } \\
\text { projeto com sucesso. O gerenciamento do escopo do projeto está } \\
\text { relacionado principalmente com a definição e controle do que está e } \\
\text { do que não está incluso no projeto. }\end{array}$ \\
\hline $\begin{array}{c}\text { Gerenciamento do } \\
\text { tempo }\end{array}$ & $\begin{array}{l}\text { Inclui os processos necessários para gerenciar o término pontual do } \\
\text { projeto. }\end{array}$ \\
\hline $\begin{array}{l}\text { Gerenciamento dos } \\
\text { Custos }\end{array}$ & $\begin{array}{l}\text { Inclui os processos envolvidos em planejamento, estimativas, } \\
\text { orçamentos, financiamentos, gerenciamento e controle dos custos, de } \\
\text { modo que o projeto possa ser terminado dentro do orçamento } \\
\text { aprovado. }\end{array}$ \\
\hline $\begin{array}{l}\text { Gerenciamento da } \\
\text { Qualidade }\end{array}$ & $\begin{array}{l}\text { Inclui os processos e as atividades da organização executora que } \\
\text { determinam as políticas de qualidade, os objetivos e as } \\
\text { responsabilidades, de modo que o projeto satisfaça as necessidades } \\
\text { para as quais foi empreendido. }\end{array}$ \\
\hline $\begin{array}{l}\text { Gerenciamento dos } \\
\text { Recursos Humanos }\end{array}$ & $\begin{array}{l}\text { Inclui os processos que organizam, gerenciam e guiam a equipe do } \\
\text { projeto. A equipe do projeto consiste das pessoas com papéis e } \\
\text { responsabilidades designadas para completar o projeto. Os membros } \\
\text { da equipe do projeto podem ter vários conjuntos de habilidades, atuar } \\
\text { em regime de tempo integral ou parcial, e podem ser acrescentados ou } \\
\text { removidos da equipe à medida que o projeto progride. }\end{array}$ \\
\hline $\begin{array}{l}\text { Gerenciamento das } \\
\text { Comunicações }\end{array}$ & $\begin{array}{l}\text { Inclui os processos necessários para assegurar que as informações do } \\
\text { projeto sejam planejadas, coletadas, criadas, distribuídas, } \\
\text { armazenadas, recuperadas, gerenciadas, controladas, monitoradas e } \\
\text { finalmente dispostas de maneira oportuna e apropriada. }\end{array}$ \\
\hline $\begin{array}{l}\text { Gerenciamento dos } \\
\text { Riscos }\end{array}$ & $\begin{array}{l}\text { Inclui os processos de planejamento, identificação, análise, } \\
\text { planejamento de respostas e controle de riscos de um projeto. Os } \\
\text { objetivos do gerenciamento dos riscos do projeto são aumentar a } \\
\text { probabilidade e o impacto dos eventos positivos e reduzir a } \\
\text { probabilidade e o impacto dos eventos negativos no projeto. }\end{array}$ \\
\hline $\begin{array}{l}\text { Gerenciamento das } \\
\text { Aquisições }\end{array}$ & $\begin{array}{l}\text { Inclui os processos necessários para comprar ou adquirir produtos, } \\
\text { serviços ou resultados externos à equipe do projeto. A organização } \\
\text { pode ser tanto o comprador quanto o vendedor dos produtos, serviços } \\
\text { ou resultados de um projeto. }\end{array}$ \\
\hline $\begin{array}{l}\text { Gerenciamento das } \\
\text { Partes Interessadas }\end{array}$ & $\begin{array}{l}\text { Inclui os processos exigidos para identificar todas as pessoas, grupos } \\
\text { ou organizações que podem impactar ou serem impactados pelo } \\
\text { projeto, analisar as expectativas das partes interessadas e seu impacto } \\
\text { no projeto, e desenvolver estratégias de gerenciamento apropriadas } \\
\text { para o engajamento eficaz das partes interessadas nas decisões e } \\
\text { execução do projeto. }\end{array}$ \\
\hline
\end{tabular}

Fonte: PMBOK (2013) 
O Guia define aspectos importantes de cada área de conhecimento e como ela se integra com os cinco grupos de processos. Como elementos de apoio, as áreas de conhecimento fornecem uma descrição detalhada das entradas e saídas do processo e uma explicação descritiva das ferramentas e técnicas usadas com maior frequência nos processos de gerenciamento de projetos para produzir cada resultado (PMI, 2013, p.60).

A novidade da $5^{\circ}$ edição do PMBOK (2013) é a área de conhecimento das Partes Interessadas ou stakeholders. A análise de partes interessadas é uma técnica de coleta e análise sistemática de informações quantitativas e qualitativas para determinar os interesses que devem ser considerados durante todo o projeto. Ela identifica os interesses, as expectativas e a influência das partes interessadas e determina seu relacionamento com a finalidade do projeto (PMI, 2013, p.395).

As partes interessadas têm diversos níveis de responsabilidade e autoridade quando participam de um projeto, como apresenta a Fig. 3.4. Esse nível pode mudar ao longo do ciclo de vida do projeto. Seu envolvimento pode variar, desde contribuições ocasionais em pesquisas e grupos de discussão até o patrocínio total do projeto, que inclui o fornecimento de apoio financeiro, político, ou outro tipo de apoio.

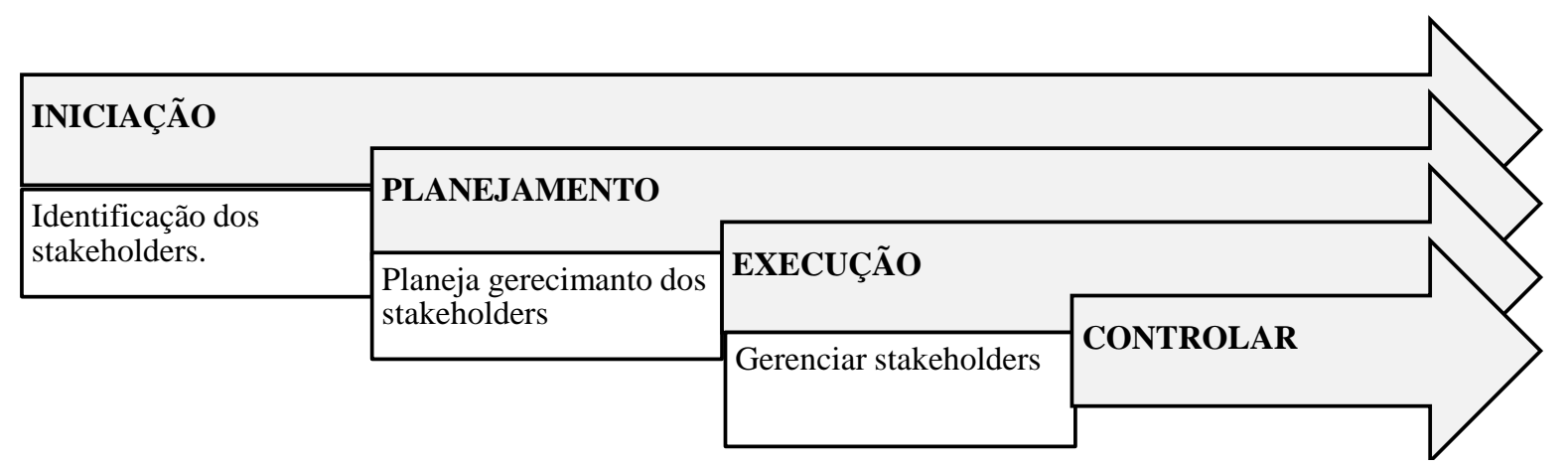

Figura 3.4 - Partes Interessadas - Stakeholders. Adaptada PMBOK (2013)

Planejar o Gerenciamento das Partes Interessadas é o processo de desenvolver estratégias apropriadas de gerenciamento para envolver as partes interessadas de maneira eficaz no decorrer de todo o ciclo de vida do projeto, com base na análise das suas necessidades, interesses, e impacto potencial no êxito do projeto (PMI, 2013, p.399).

Destarte, é importante destacar o ciclo de vida do projeto, que pode ser definido ou moldado de acordo com aspectos exclusivos da organização, setor ou tecnologia empregada. Embora todos os projetos tenham um início e um fim definidos, as entregas e atividades específicas conduzidas nesse ínterim poderão variar muito de acordo com o projeto. Conforme apresenta a 
Fig.3.5, o ciclo de vida oferece uma estrutura básica para o gerenciamento do projeto, independentemente do trabalho específico envolvido.

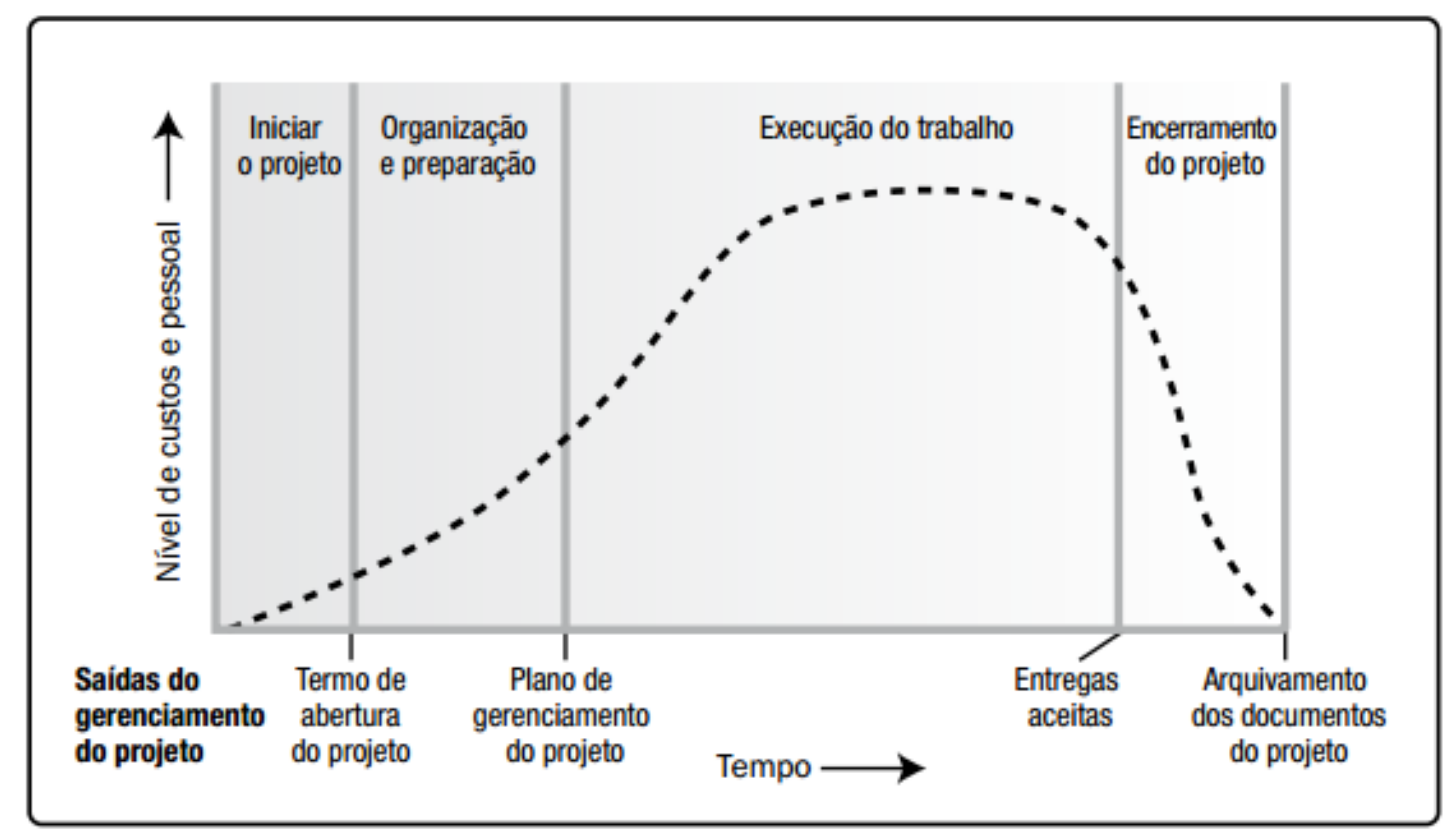

Figura 3.5 - Níveis típicos de custo e pessoal em toda a estrutura genérica do ciclo de vida de um projeto. Adaptado PMBOK (2013)

Os ciclos de vida adaptativos, em especial, são desenvolvidos com o intuito de manter o grau de influência das partes interessadas mais alto e os custos das mudanças mais baixos do que nos ciclos de vida previsíveis. Assim apresenta a Fig. 3.6.

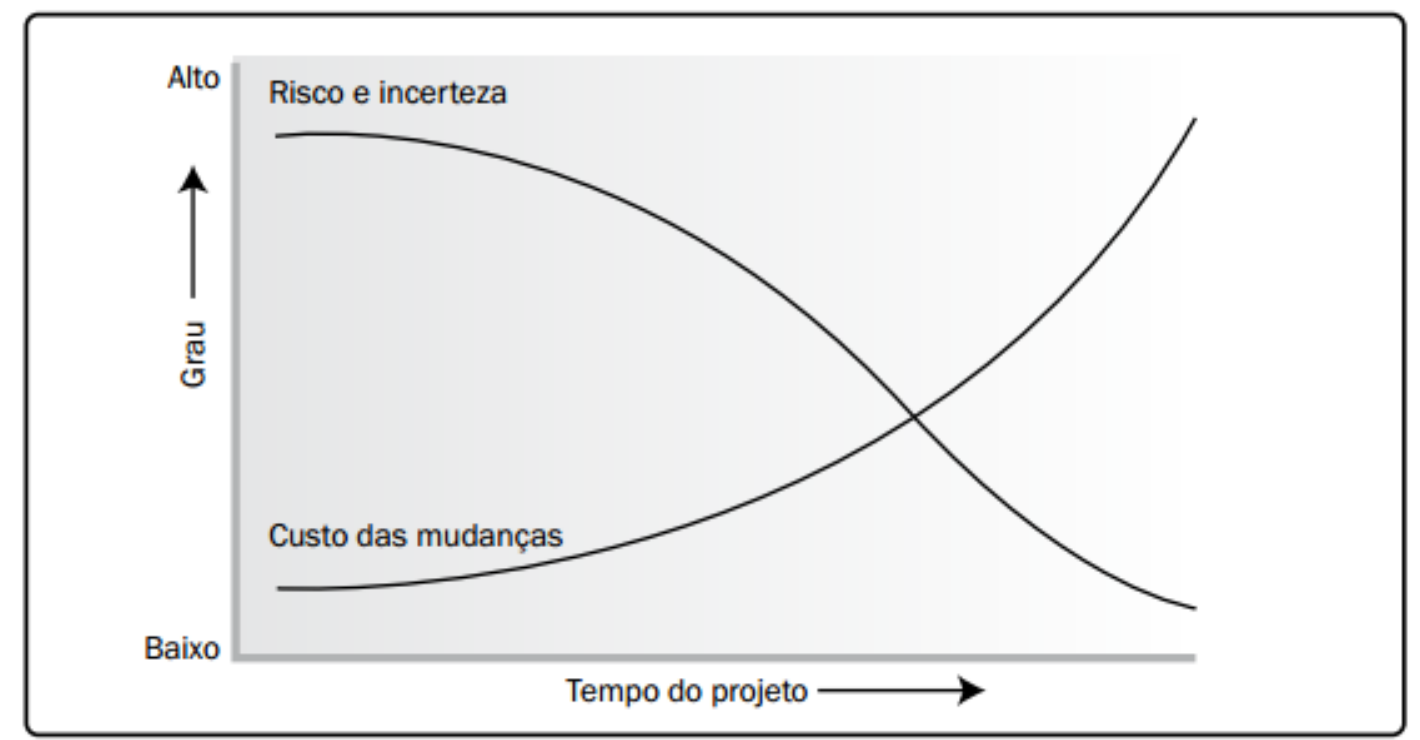

Figura 3.6 - Impacto da variável com base no tempo decorrido do projeto. Adaptado PMBOK (2013) 
Segundo Donaldson \& Preston (1995), o termo stakeholder foi inicialmente empregado na área de administração em um memorando interno do Stanford Research Institute (SRI) em 1963. O conceito inicial do termo era designar todos os grupos sem os quais a empresa deixaria de existir. A definição mais empregada na literatura do termo stakeholder é a de Freeman (1984), segunda a qual stakeholder é qualquer indivíduo ou grupo que possa afetar a obtenção dos objetivos organizacionais ou que é afetado pelo processo de busca desses objetivos.

Já a teoria dos stakeholders possui origens na sociologia, comportamento organizacional e administração de conflitos, onde nos estudos empíricos predominam métodos qualitativos. Essas diferenças de origem conceitual e de abordagens metodológicas entre as duas teorias são suficientes para explicar a complexidade que envolve a discussão desse tema e diversas são as diferenças entre as duas teorias. Nesse sentido, como a teoria dos stakeholders é explicativa e normativa, segundo Jones \&Wicks (1999), esta se constitui em um importante recurso para demonstrar como os gestores devem agir em relação aos negócios.

\subsection{GESTÃO ESTRATÉGICA}

Como conceito etimológico, a estratégia foi criada pelos gregos, que deram ao conceito uma conotação militar. O termo estratégia origina-se do grego strategos, sendo traduzida como "general no comando de tropas" ou "a arte do general". Contudo, somente após a Segunda Guerra Mundial que a estratégia passou a fazer parte da história das empresas. Os termos e sua aplicação cresceram significativamente e vários teóricos passaram a estudar sua aplicação. Devido ao crescimento significativo das empresas após a Revolução Industrial, muitas precisavam de diretrizes, linhas e caminhos a serem seguidos por toda a sua estrutura (BRACKER, 1980).

Segundo Fahey (1989), “estratégia” é uma das poucas palavras que é objeto de muitos abusos no uso corporativo, sendo mal colocada na literatura de gestão e alocada sob diferentes formas e significados. Nesse formato, o termo provoca muitas discussões. De acordo com Porter (1996), a estratégia tem uma amplitude e abrangência que engloba o conceito de eficácia operacional e não pode ser confundida com suas táticas.

Herrero Filho (2011) argumenta sobre a falta de entendimento de boa parte das pessoas sobre estratégia. $\mathrm{O}$ autor elenca algumas definições importantes sobre estratégia, como apresentado no Quadro 3.4. 
Quadro 3.4 - Definições sobre estratégia

\begin{tabular}{|c|l|}
\hline Autor & \multicolumn{1}{|c|}{ Definição } \\
\hline Chandler (1962) & $\begin{array}{l}\text { “A estratégia pode ser definida como a determinação das metas e de } \\
\text { objetivos básicos no longo prazo de uma empresa, bem como a adoção } \\
\text { de cursos de ação e alocação dos recursos necessários à consecução } \\
\text { dessas metas." (CHANDLER, 1962, apud HERRERO FILHO, 2011, } \\
\text { p. 4) }\end{array}$ \\
$\begin{array}{c}\text { "A estratégia competitiva consiste em ser diferente, em se diferenciar. } \\
\text { Michael Porter } \\
\text { (1985) } \\
\text { atividades em relação aos concorrentes para fornecer um mix único de } \\
\text { valor.” (MICHAEL PORTER, 1985 apud HERRERO FILHO, 2011, } \\
\text { p. 4). }\end{array}$ \\
$\begin{array}{c}\text { Ikujiro Nonaka e e } \\
\text { Hirotaka Takeuchi } \\
\text { (1997) }\end{array}$ & $\begin{array}{l}\text { "A essência da estratégia está no desenvolvimento da capacidade } \\
\text { conhecimento.” (IKUJIRO NONAKA \& HIROTAKA TAKEUCHI, } \\
\text { 1997, apud HERRERO FILHO, 2011, p. 4). }\end{array}$ \\
\hline $\begin{array}{c}\text { Walter kiechel III } \\
\text { (2010) }\end{array}$ & $\begin{array}{l}\text { "A estratégia é apresentada como paradigma por meio do qual as } \\
\text { pessoas no mundo dos negócios organizam sua compreensão do que } \\
\text { uma empresa pode fazer." (WALTER KIECHEL III, 2010 apud } \\
\text { HERRERO FILHO, 2011, p. 4). }\end{array}$ \\
\hline
\end{tabular}

Fonte: Herrero Filho (2011)

Para Porter (1996), a gestão estratégica surgiu como elemento do planejamento estratégico, que é apresentado como um dos seus principais instrumentos. Ele foi incorporado pela gestão estratégica, que atrelou num mesmo processo planejamento e gestão. Essa pluralidade de definições torna a estratégia um conceito complexo e carregado de subjetividade e a finalidade essencial da estratégia, como formulação e execução, perde-se no espaço e no tempo.

Para Herrero Filho (2011), a questão da execução, apesar de ser o elo perdido da estratégia, somente foi abordada diretamente em 2002, por Larry Bossidy e Ram Charan, em seu livro Execução, onde a responsabilidade da elaboração da estratégia é da alta administração, e a execução da estratégia fica a cargo da gerência, provocando um hiato entre a formulação e a execução da estratégia. Nesse ponto, muitas vezes o fracasso de um projeto ou programa está na execução desvinculada de sua estratégia.

O principal instrumento que dá subsídio à gestão estratégica de uma organização é o Planejamento Estratégico, conforme apresenta a Fig 3.7. 


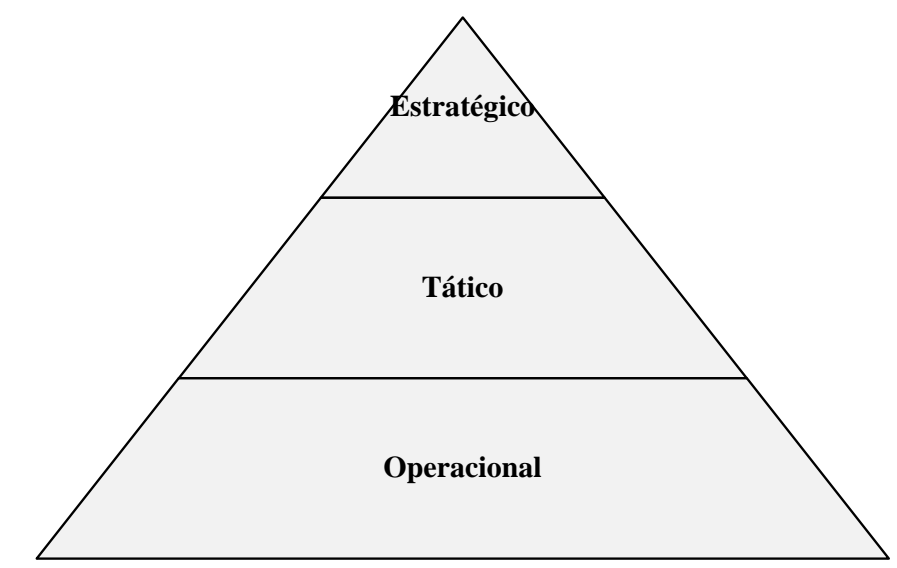

Figura 3.7 - Níveis de planejamento - Pirâmide organizacional. Adaptado Chiavenato (2000)

O planejamento estratégico está relacionado com os objetivos de longo prazo e com as ações que serão realizadas para alcançá-los e que afetam a organização como um todo. Ele é conceituado como um processo gerencial que possibilita ao executivo estabelecer o rumo a ser seguido. É geralmente de responsabilidade dos níveis mais altos da empresa. Na prática, sem o envolvimento direto do principal lider da empresa, dificilmente ocorrerá um plano estratégico eficiente.

Num segundo nível, o planejamento tático está relacionado aos objetivos de curto prazo e às ações que afetam somente uma parte da organização. Ele tem como objetivo otimizar determinada área e não a empresa como um todo, sendo desempenhado por níveis organizacionais inferiores.

E em um terceiro nível, o planejamento operacional, por sua vez, pode ser considerado como a formalização das metodologias de desenvolvimento e implantação estabelecidas. Nesse nível se encontram, basicamente, os planos de ação ou planos operacionais.

Um dos métodos para a formulação de estratégia é a Matriz SWOT, desenvolvida na Harvard Business School, que resulta das palavras Strengths (forças), Weaknesses (fraquezas), Opportunities (oportunidades) e Threats (ameaças). A análise SWOT levanta informações para uma série de decisões sobre que oportunidades serão aproveitadas, quais ameaças serão enfrentadas, que pontos fracos serão minimizados e que pontos fortes serão fortalecidos na implantação de uma estratégica.

A Matriz SWOT consiste na avaliação da posição competitiva de uma empresa no mercado por meio do recurso a uma matriz de dois eixos, cada um dos quais composto por duas variações: pontos fortes (Strenghts) e pontos fracos (Weaknesses) da análise interna; oportunidades 
(Opportunities) e ameaças (Threats) da análise externa. A matriz é uma importante ferramenta para o processo de tomada de decisão. A Fig. 3.8 demonstra esquematicamente a matriz.

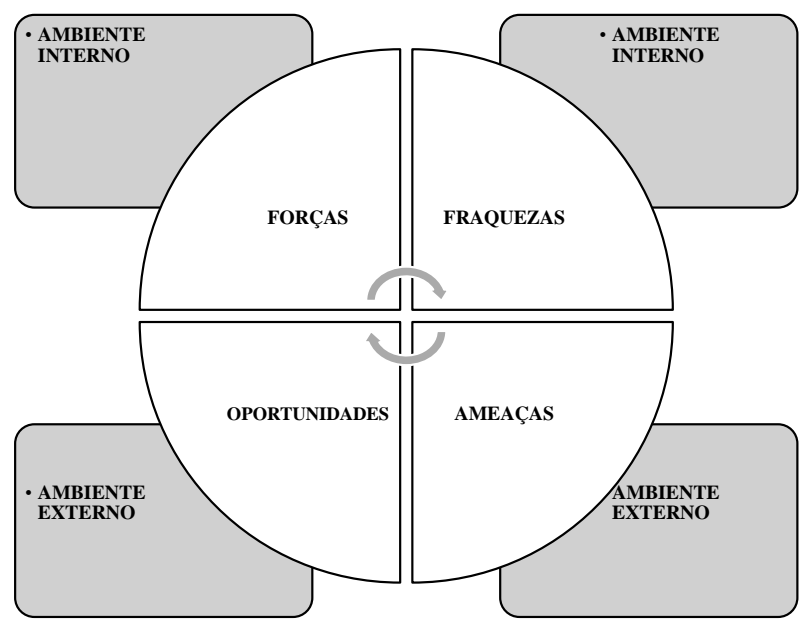

Figura 3.8 - Matriz SWOT. Adaptado Kotler e Keller (2006).

As Cinco Forças de Porter, concebidas por Michael Porter em 1979, consistem em uma série coerente de ações ofensivas ou defensivas, formuladas com o intuito de proporcionar à organização uma posição sólida no mercado em que atua, e de superar a concorrência por meio do desenvolvimento de uma estratégia empresarial eficiente.

Porter (1999) alega que a posição de mercado é alcançada por meio do domínio das cinco forças competitivas que delimitam a concorrência em uma indústria. São elas: ameaça de novos entrantes, poder de barganha dos fornecedores, poder de barganha dos compradores, ameaça de produtos ou serviços substitutos e rivalidade entre concorrentes, conforme apresenta a Fig 3.9.

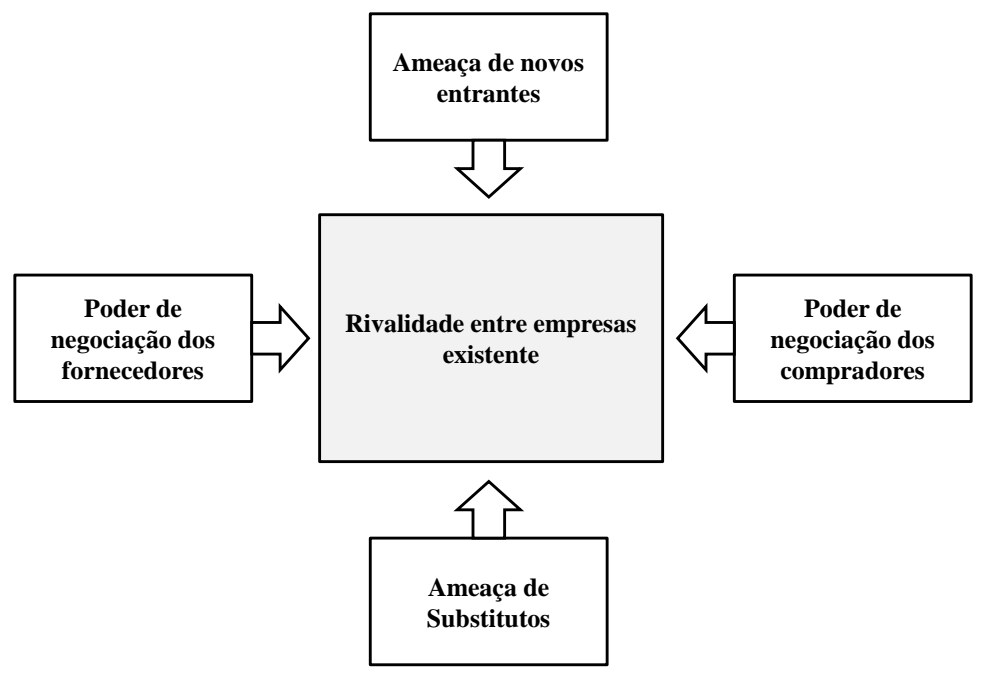

Figura 3.9 - Modelo das Cinco Forças de Porter. Adaptado Porter (1986). 
Importante observar que, quando Porter menciona a indústria, utiliza esse termo de forma bastante ampla e genérica. Mas o termo se encaixa em qualquer indústria, seja ela doméstica ou internacional, que produza um produto ou um serviço, ou vários produtos e serviços. O que o modelo explora são regras da concorrência, que estão englobadas nas cinco forças competitivas. Em síntese, sua eficácia coletiva emana das habilidades das empresas em um sistema de indústria. (PORTER, 1986)

Outro importante estudo no tema de estratégia é o Balanced Scorecard (BSC), cuja data de criação remonta a 1990, época em que pesquisadores buscavam novos métodos de avaliação de desempenho, diferentes daqueles apoiados apenas em indicadores financeiros. A primeira definição do BSC era de um sistema de medição de desempenho. Depois da transformação, passou a ser definido como um sistema de gestão estratégica. (KAPLAN \& NORTON, 1997)

O BSC reflete vários tipos balanceamento, seja de objetivos de curto e de longo prazo, entre indicadores financeiros e não financeiros, entre indicadores de resultados ocorridos e de tendências de desempenho futuro, entre uma visão interna de desempenho e outra externa, voltada para clientes e acionistas. Também remete a resultados subjetivos e quantificáveis que tratam de diretrizes e objetivos que precisam ser medidos. (KAPLAN \& NORTON, 1997) A Fig. 3.10 apresenta o fluxo direto do BSC.

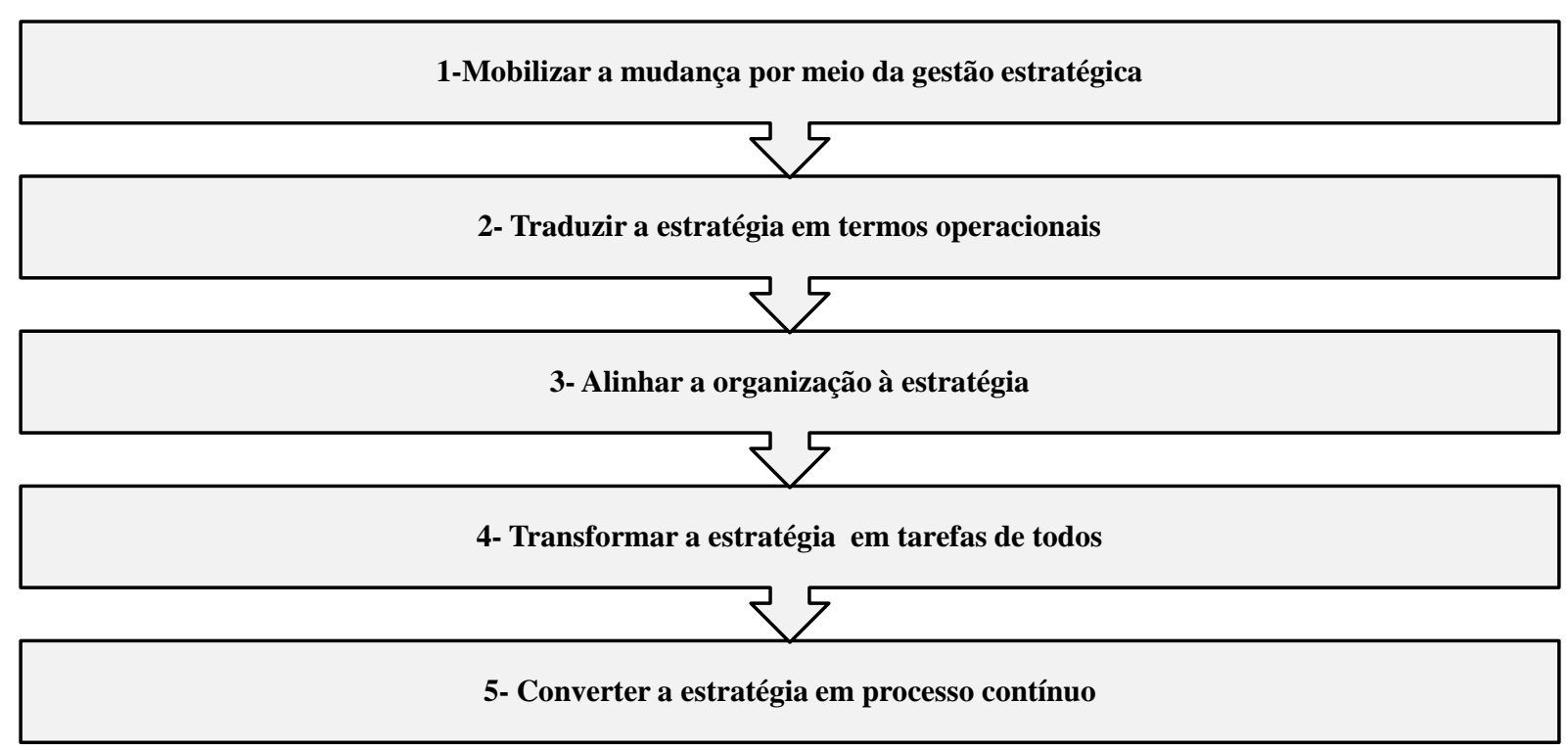

Figura 3.10 - Sistema de Gestão BSC. Elaboração própria 
Os conceitos advindos do planejamento empresarial, assim compreendidos pela Harvard Business School, podem ser adotados pelos governos locais em razão de as cidades estarem submetidas às mesmas condições e desafios que as empresas (ARANTES et al., 2000). A administração pública brasileira vem se ajustando a novas práticas de gestão e tem modificado sua forma de atuar, adotando práticas administrativas mais modernas, já amplamente utilizadas na gestão de empresas privadas, como a aplicação da gestão de projetos.

Fazendo uma analogia ao ambiente de políticas públicas, especificamente na PNMU, ponderase que o planejamento estratégico se orienta pela Lei de Mobilidade, como forma de política estratégica, que norteará a gestão municipal por meio dos princípios, diretrizes e objetivos contidos na lei, cujo resultado prático seja a construção e operacionalização dos planos de mobilidade na esfera municipal. A Fig. 3.11 apresenta os níveis estratégicos que sustentam a política de transporte.

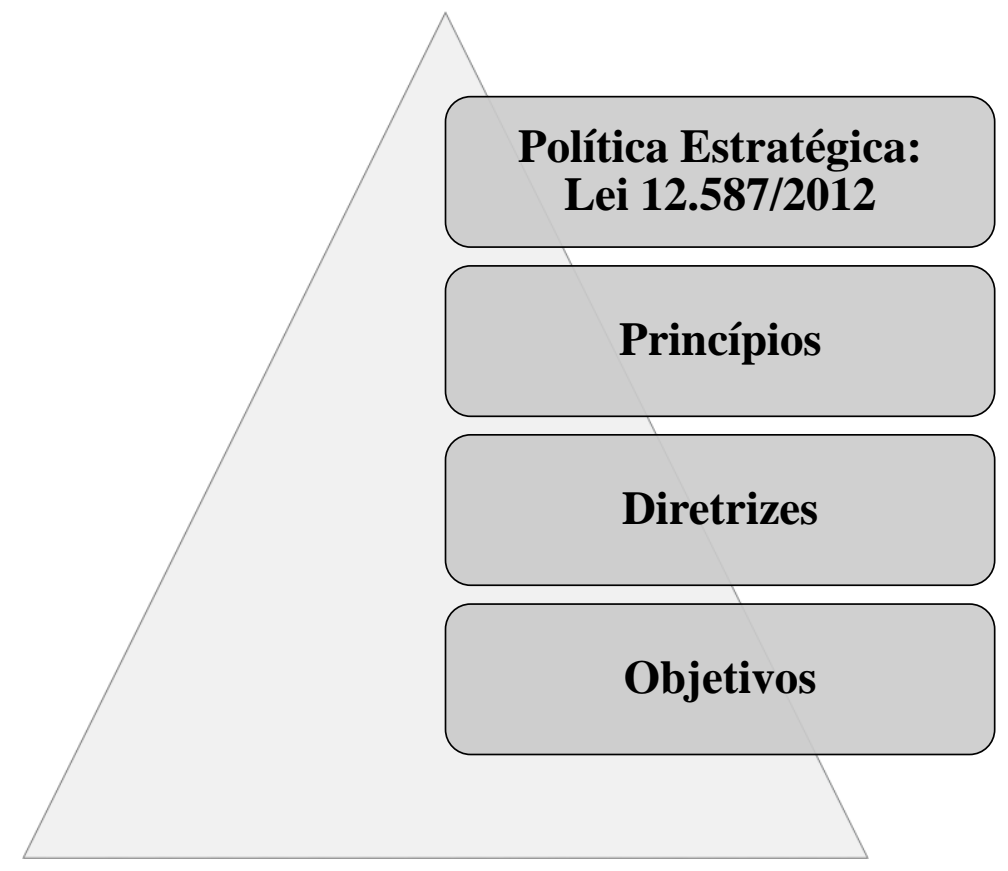

Figura 3.11 - Níveis estratégicos da política de transporte. Adaptado SMT/SP-2011

Várias circunstâncias podem influenciar os gestores de um município a estabelecer um pensamento estratégico, e algumas ações podem facilitar a aplicação de uma gestão estratégica eficiente, como a busca de consenso junto à sociedade sobre o melhor modelo para o futuro da cidade no âmbito da governança, a realização de mapeamento dos problemas e a listagem das prioridades e o tempo de resposta adequado, além da busca pela coesão e pela integração territorial nas ações de curto, médio e longo prazo. 
De forma a evidenciar o conteúdo deste trabalho, destaca-se como aplicação estratégica a PNMU, que disponibiliza para gestores municipais um conjunto de instrumentos que podem ser utilizados na gestão da mobilidade. O principal deles é o plano municipal de mobilidade, que deve integrar o planejamento urbano, transporte e uso do solo, observando os princípios de sustentabilidade e equidade social para desestimular o uso do transporte individual motorizado. (BRASIL, 2015)

Destarte, vale ressaltar que a estrutura de sustentação e as premissas para criar um planejamento estratégico adequado derivam da capacidade do ente municipal. Como exemplo, cita-se Mancini \& Rodrigues da Silva (2010), que destacam a necessidade de apontar ações estratégicas para orientar gestores e técnicos no sentido de alcançar padrões de geração de viagens que conduzam à mobilidade sustentável, devido ao baixo know-how para elaboração e implementação de planos de mobilidade apresentado por estes.

\subsection{TÓPICOS CONCLUSIVOS}

Este capítulo buscou mostrar os aspectos que norteiam a gestão pública e suas relações com o debate sobre estratégia no âmbito das organizações (sejam elas públicas e privadas). Sob essa perspectiva, a PNMU como um processo de descentralização de políticas públicas exige a materialização de um modelo de gestão pública moderna, capaz de suportar as estreitas demandas da Lei 12.587/2012.

Segundo Gomide (2008, p.22), "numa democracia, o processo político é, por natureza, complexo, desordenado, permeado por conflitos, ambiguidades e contradições; produz acordos, conciliações e ajustes, cuja avaliação com base na variedade de interesses em jogo é sempre inconclusa". Nesse contexto, a responsabilidade e a competência da gestão política estratégica a nível local passam a ter um peso significativo na aplicação de políticas públicas do ente municipal, a ponto de superar tais dificuldades.

As referências deste capítulo inclinam a dizer que a linha estratégica e os desdobramentos táticos e operacionais a serem atingidos numa política pública, em grande parte, devem-se à sinergia entre decisor (gestor político) e gestores técnicos (executores). Sendo o decisor aquele que, em tese, carrega a agenda política decorrente das "promessas de campanha", onde a participação popular está implícita nessa figura política, resultante dos efeitos da democracia representativa. 


\section{MÉTODO MULTICRITÉRIO DE AVALIÇÃO DA POLÍTICA DE MOBILIDADE URBANA}

Neste capítulo, são apresentadas considerações a respeito do método de Análise Multicritério de Apoio à Decisão denominado Macbeth e suas aplicações no programa M-Macbeth. Em seguida, será apresentado o percurso metodológico para se atingirem os objetivos do trabalho na utilização do referido programa, quais sejam: (a) definição das opções comparáveis; (b) estruturação da árvore de critério; (c) validação dos julgamentos; (d) validação dos julgamentos; (e) ordenações conforme avaliação do decisor; (f) inserção de dados qualitativos; (g) obtenção de resultados e gráfico.

\subsection{CONSIDERAÇÕES INICIAIS}

A Análise Multicritério de Apoio à Decisão, ou de forma simplificada, Análise de Decisão Multicritério (MCDA), pode ser definida, conforme Gomes et al. (2004), como o combinado de métodos cujo objetivo é analisar um grupo de alternativas sobre múltiplos critérios para resolver um determinado problema.

A análise de decisão multicritério é um processo interativo, mas pode ser interpretado como a sequência das seguintes etapas (GOMES, 2004):

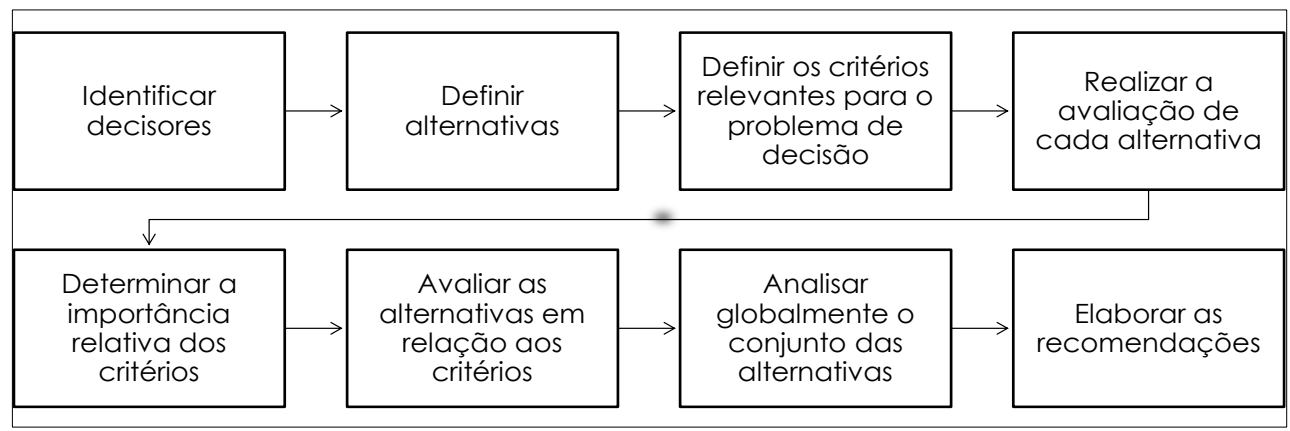

Figura 4.1 - Etapas da análise decisão multicritério. Adaptado Gomes (2004)

Cabe salientar que o processo de decisão faz parte do cotidiano das pessoas. "Quando se está trabalhando com modelos formais, seja para apoiar a decisão (como fazem as metodologias Multicritério em apoio à decisão - MCDA), seja para tomar a decisão (como advoga a pesquisa operacional tradicional) é necessário definir claramente as regras de trabalho a serem utilizadas”. (ENSSLIN, MONTIBELLER, LIMA 2001, p.15). 
Nesse sentido, Jannuzzi et al. (2009) afirmam quanto à análise multicritério:

Trata-se, pois, de uma técnica que permite que a decisão seja pautada com base nos critérios considerados relevantes para o problema em questão pelos agentes decisores, em que a importância dos critérios é definida por estes, em um processo interativo com outros atores técnicopolíticos. Afinal, cada ministério, cada secretaria estadual ou municipal, cada gestor tem, de partida, um elenco de objetivos setoriais a orientar sua agenda de prioridades, conferindo maior importância a determinadas questões sociais e estratégias de intervenção. (JANNUZZI et al., 2009)

Na Fig. 4.2, é apresentado o procedimento metodológico a ser seguido para a obtenção do modelo multicritério e dos resultados.

\begin{tabular}{|c|c|c|}
\hline $1^{\mathrm{a}}$ Fase & $\begin{array}{l}\text { - Considerações iniciais } \\
\text { - Definição das opções } \\
\text { comparáveis }\end{array}$ & \\
\hline \multirow{2}{*}{$2^{\mathrm{a}}$ Fase } & \multirow{2}{*}{$\begin{array}{l}\text { - Estruturação da árvore de pontos } \\
\text { de vista } \\
\text { - Validação dos julgamentos }\end{array}$} & Pontos de vista fundamentais (PVF) \\
\hline & & Pontos de vista elementares (PVE) \\
\hline \multirow{2}{*}{$3^{\mathrm{a}}$ Fase } & \multirow{2}{*}{$\begin{array}{l}\text { Ordenações conforme avaliação } \\
\text { do Decisor } \\
\text { - Inserção de dados das avaliações } \\
\text { qualitativas }\end{array}$} & Questionário Decisor \\
\hline & & Questionários Gestores \\
\hline $4^{\mathrm{a}}$ Fase & - Obtenção de resultados e gráficos & \\
\hline
\end{tabular}

Figura 4.2 - Procedimentos metodológicos

\subsection{ANÁLISE MULTICRITÉRIO DE APOIO A DECISÃO MACBETH}

As metodologias voltadas ao Apoio à Decisão, adotam o construtivismo como paradigma cientifico, ao contrário das metodologias voltadas à tomada de decisão, que seguem o paradigma racionalista. Assim, as metodologias MCDAs enquadram-se no primeiro caso, enquanto a pesquisa operacional tradicional enquadra-se no segundo caso. (ENSSLIN, MONTIBELLER, LIMA, 2001)

Segundo Kuhn (2006, p.145), "paradigmas são parte constitutiva da ciência”. Nesse aspecto, a escolha de um paradigma científico a ser usado é consequência dos valores daqueles facilitadores envolvidos em apoiar/tomar as decisões. Entretanto, “o paradigma construtivista é o mais apropriado em fornecer apoio aos processos decisórios que envolvem situações 
complexas" (ENSSLIN, MONIBELLER, LIMA, 2001, p.35). A Tab. 4.1 apresenta um comparativo entre as características de cada paradigma.

Tabela 4.1- Comparativo entre paradigmas racionalista e construtivista

\begin{tabular}{|c|c|c|}
\hline & Paradigma Racionalista & $\begin{array}{c}\text { Paradigma } \\
\text { Construtivista }\end{array}$ \\
\hline Tomada de Decisão & $\begin{array}{l}\text { Momento em que ocorre a } \\
\text { escolha da solução ótima }\end{array}$ & $\begin{array}{l}\text { Processo ao longo do } \\
\text { tempo envolvendo } \\
\text { interação entre os atores }\end{array}$ \\
\hline Decisor & Totalmente racional & $\begin{array}{l}\text { Dotado de sistema de } \\
\text { valores próprios }\end{array}$ \\
\hline $\begin{array}{l}\text { Problema a ser } \\
\text { Resolvido }\end{array}$ & Problema real & Problema construído \\
\hline Os Modelos & $\begin{array}{c}\text { Representam a realidade } \\
\text { objetiva }\end{array}$ & $\begin{array}{c}\text { São ferramentas aceitas } \\
\text { pelos decisores como úteis } \\
\text { no Apoio à Decisão }\end{array}$ \\
\hline $\begin{array}{l}\text { Os Resultados dos } \\
\text { Modelos }\end{array}$ & Soluções ótimas & $\begin{array}{c}\text { Recomendações que viam } \\
\text { atender aos valores dos } \\
\text { decisores }\end{array}$ \\
\hline $\begin{array}{l}\text { O Objetivo da } \\
\text { Modelagem }\end{array}$ & Encontrar a solução ótima & $\begin{array}{c}\text { Gerar conhecimento aos } \\
\text { decisores sobre seu } \\
\text { problema }\end{array}$ \\
\hline $\begin{array}{l}\text { A Validação do } \\
\text { Modelo }\end{array}$ & $\begin{array}{c}\text { Modelo é válido quando } \\
\text { representa a realidade } \\
\text { objetivamente }\end{array}$ & $\begin{array}{c}\text { Modelo é válido quando } \\
\text { serve como ferramenta de } \\
\text { Apoio à Decisão }\end{array}$ \\
\hline $\begin{array}{l}\text { Preferência dos } \\
\text { Decisores }\end{array}$ & $\begin{array}{l}\text { São extraídos pelos } \\
\text { analistas }\end{array}$ & $\begin{array}{l}\text { São construídas com o } \\
\text { facilitador }\end{array}$ \\
\hline Forma de Atuação & Tomada de decisão & Apoio à Decisão \\
\hline
\end{tabular}

Fonte: Ensslin, Montibeller, Lima, (2001)

Segundo Roy (1996), o Apoio à Decisão pode ser definido como uma atividade em que o facilitador, de forma científica (segundo o paradigma construtivista), busca obter elementos que respondam a questões levantadas pelos decisores em um processo decisório. Esses elementos ajudam a clarificar sua decisão. Assim, o facilitador deve fornecer condições favoráveis para que os decisores comportem-se de tal forma que sejam atingidos os objetivos da pesquisa. 
A opção pela ferramenta MCDA adequada à solução de um problema requer uma avaliação cautelosa, pois deve-se levar em consideração as vantagens e desvantagens de cada método. Não só pela relação de aplicabilidade ao problema, mas também pela as prioridades pessoais dos decisores relacionados no procedimento. Para cada problema em concreto, haverá um método multicritério de apoio à decisão adequado a cada necessidade.

Um problema caracteriza-se como uma situação onde o decisor deseja que alguma coisa seja diferente de como é e não está muito seguro de como obtê-la (EDEN et al., 1983). Seguindo o paradigma construtivista, considera-se que cada decisor constrói seu problema a partir das informações do contexto decisório percebidas e interpretadas por ele. O problema do decisor pode ser interpretado por meio de mapa cognitivo.

A preocupação inicial da estruturação de um modelo multicritério é definir quais são os aspectos, dentro do contexto, que o decisor e o facilitador consideram essenciais e desejáveis de serem levados em conta num processo de avaliação das ações. Tais aspectos constituem o eixo de avaliação do problema, e a identificação dos eixos é chamada de transição de um mapa cognitivo (Fig. 4.3) para um modelo multicritério.

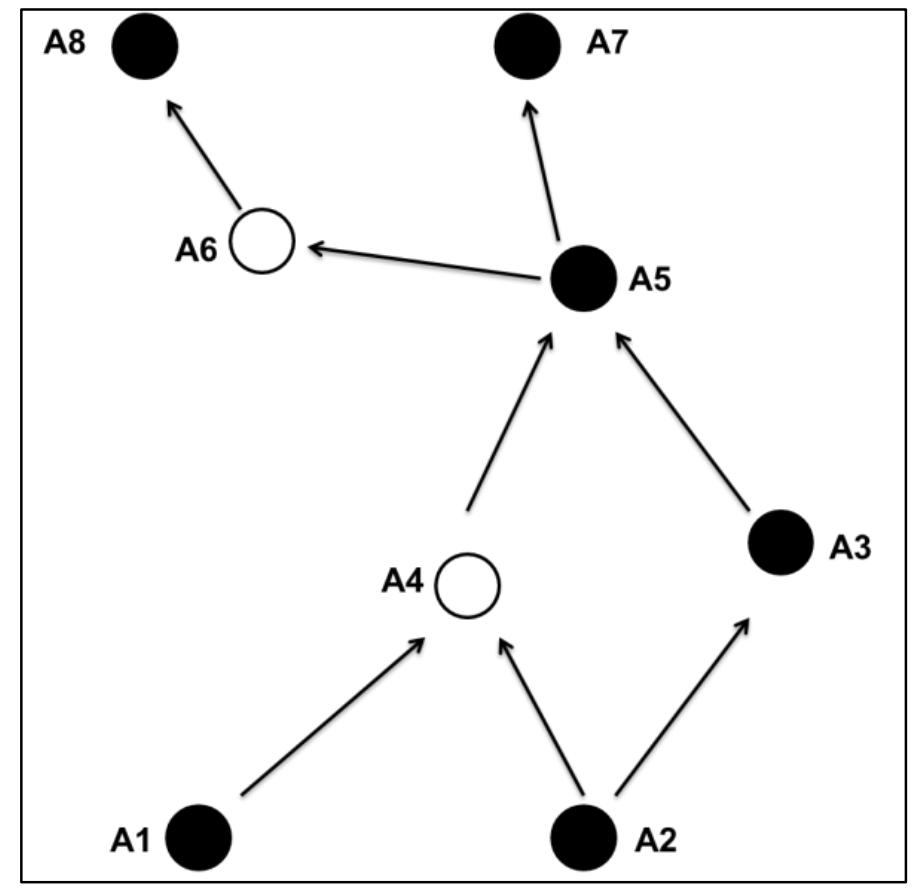

Figura 4.3 - Exemplo de Mapa Cognitivo. Adaptado Jardim (2003)

A estrutura de modelo multicritério apresentada neste trabalho é a de árvore e não de mapa cognitivo, dada a definição clara da fonte dos critérios de avaliação. Assim, a estrutura de árvore passa ser a referência do modelo. A composição em árvore utiliza a lógica de decomposição 
em que um critério mais complexo de ser mensurado é decomposto em subcritérios de mais fácil mensuração. A Fig. 4.4 mostra o critério de nível hierárquico superior definido pelo conjunto de critérios de nível hierárquico inferior que estão ligados a ele em árvore.

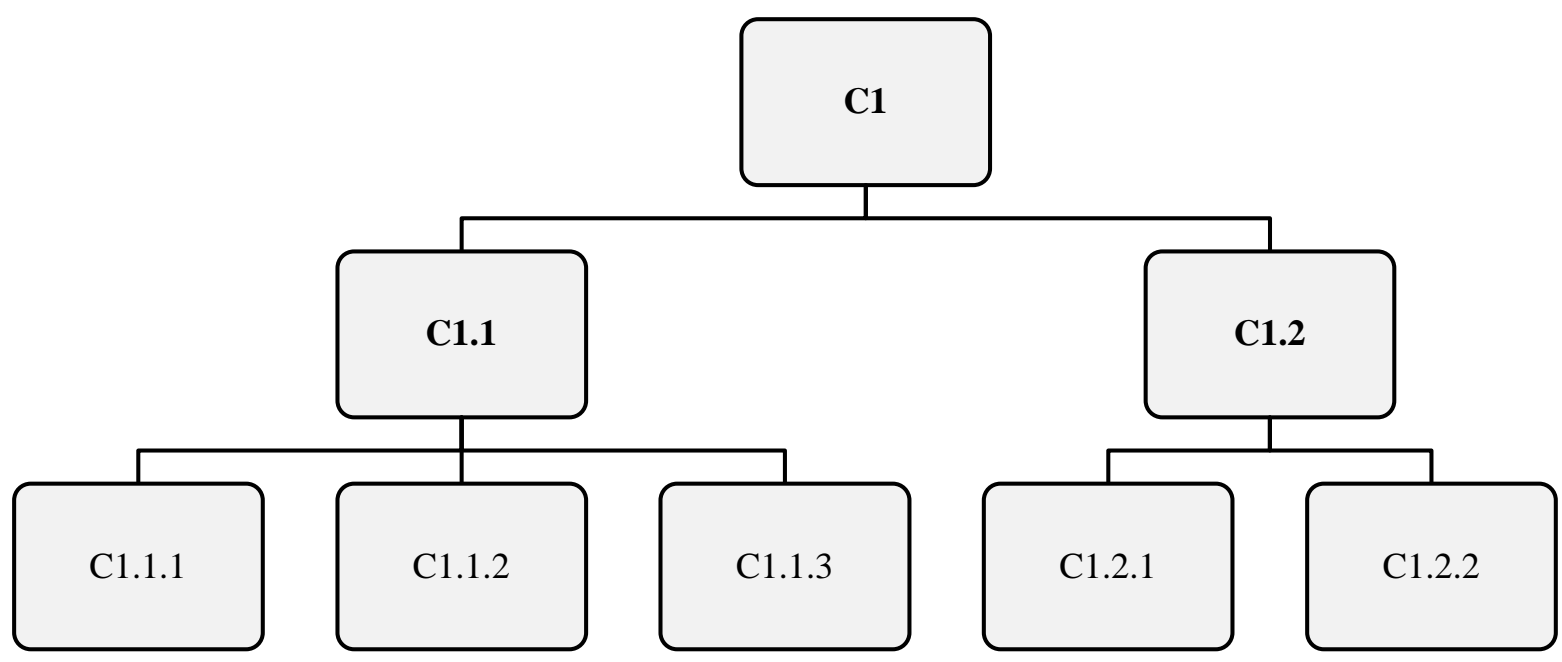

Figura 4.4 - Estrutura de modelo multicritério. Adaptado de Ensslin, Montibeller, Lima (2001)

Os critérios de nível hierarquicamente inferior devem ser mutuamente exclusivos e coletivamente necessitam fornecer uma caracterização completa do critério de nível hierarquicamente superior. Segundo Keeney (1992), devem existir pelo menos dois critérios de nível hierarquicamente inferior conectados ao critério de nível hierarquicamente superior.

Se, por um lado, os mapas cognitivos são mais ricos em informação sobre como os decisores constroem seu problema, por outro a arborescência permite melhor organizar e hierarquizar os diversos aspectos a serem levados em conta quando da avaliação das ações. Como os mapas e as árvores têm estruturas diferenciadas, a transposição do primeiro para o segundo não é automática. Enquanto estruturas arborescentes apresentam os critérios de forma simples e clara, em um mapa cognitivo pode haver relacionamentos complexos entre conceitos. (ENSSLIN, 2001)

Diante das alternativas de modelos multicritérios (MCDA) disponíveis, a preferência foi dada ao método multicritério de avaliação Macbeth. A escolha do método foi em função da simplicidade de aplicação do modelo, face à agregação ao problema proposto. De forma geral, o método auxilia em reduzir o subjetivismo das alternativas por meio de sua programação. $\mathrm{O}$ quadro 4.1 apresenta pontos positivos e negativos de alguns modelos de análise multicritério que concorrem com o Macbeth. 
Quadro 4.1- Pontos positivos e negativos de modelos MCDA

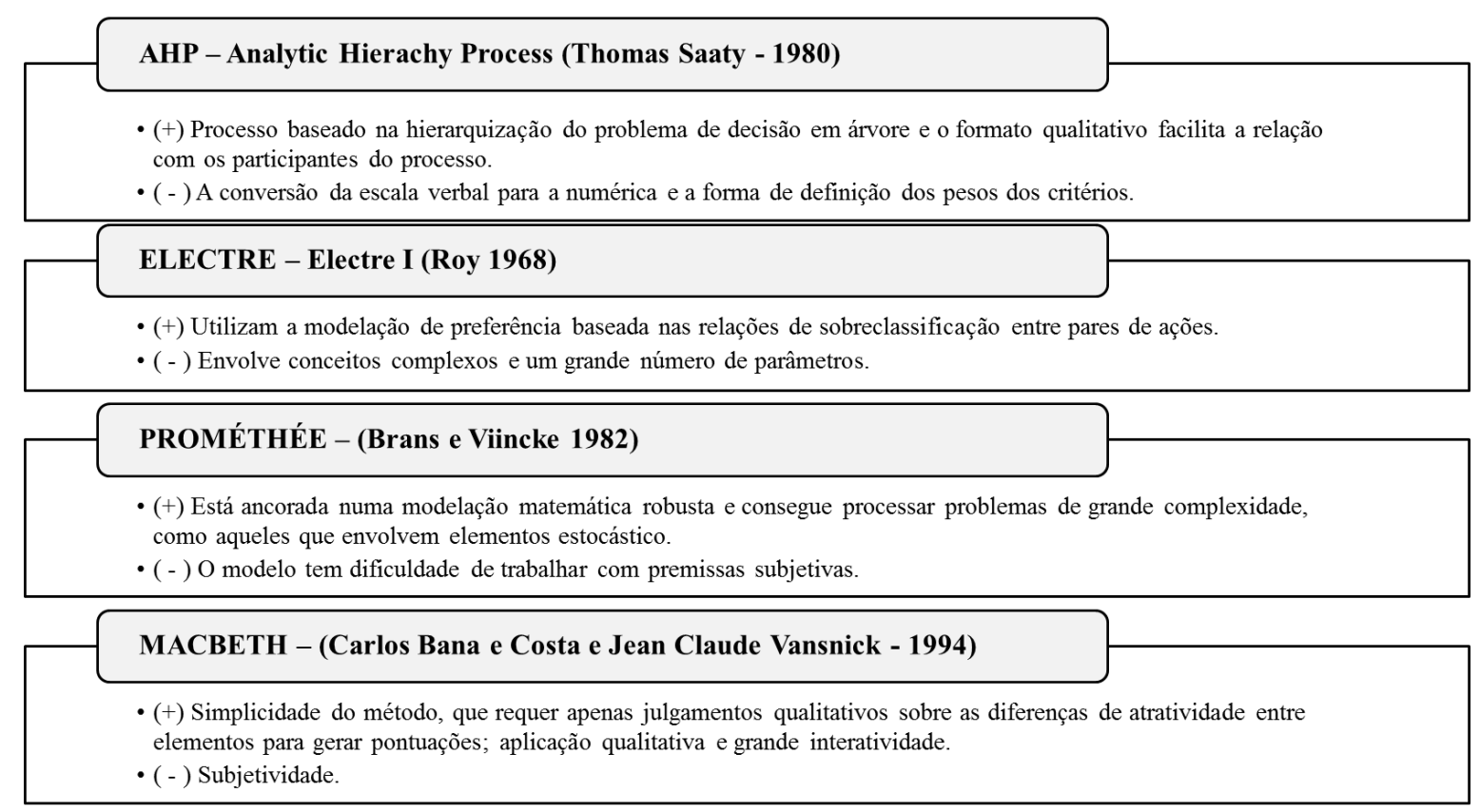

O método adotado nesta dissertação, dado o caráter qualitativo da pesquisa, foi o Macbeth desenvolvido por Bana e Costa, pois permite aditar diversos critérios de avaliação em um critério único de composição por meio da atribuição de pesos aos múltiplos critérios apresentados, acatando sempre a opinião do decisor.

Por meio de julgamentos do conjunto de preferências do decisor, o método Macbeth é operacionalizado. Após a inserção das escolhas do decisor, é gerada uma escala de valor que representa os julgamentos deste. Seguindo o processo de preferência do decisor, de forma sistêmica são gerados os pesos para as alternativas avaliadas, o que facilita o uso do método para auxiliar na tomada de decisão, agregando valor para decisores e envolvidos. (BANA E COSTA, 1995)

Ao escolher de forma comparativa, critério com critério, sempre aos pares, buscando a escolha de atratividade entre as opções apresentadas, são atribuídos graus de preferências entre os critérios selecionados e testados. Entre duas alternativas, o decisor deve escolher qual delas é mais atrativa e qual é o grau dessa atratividade, isso num plano de escala semântica que possui correspondência com uma escala ordinal (Fig. 4.5). (LONGARAY \& ENSSLIN, 2013). 


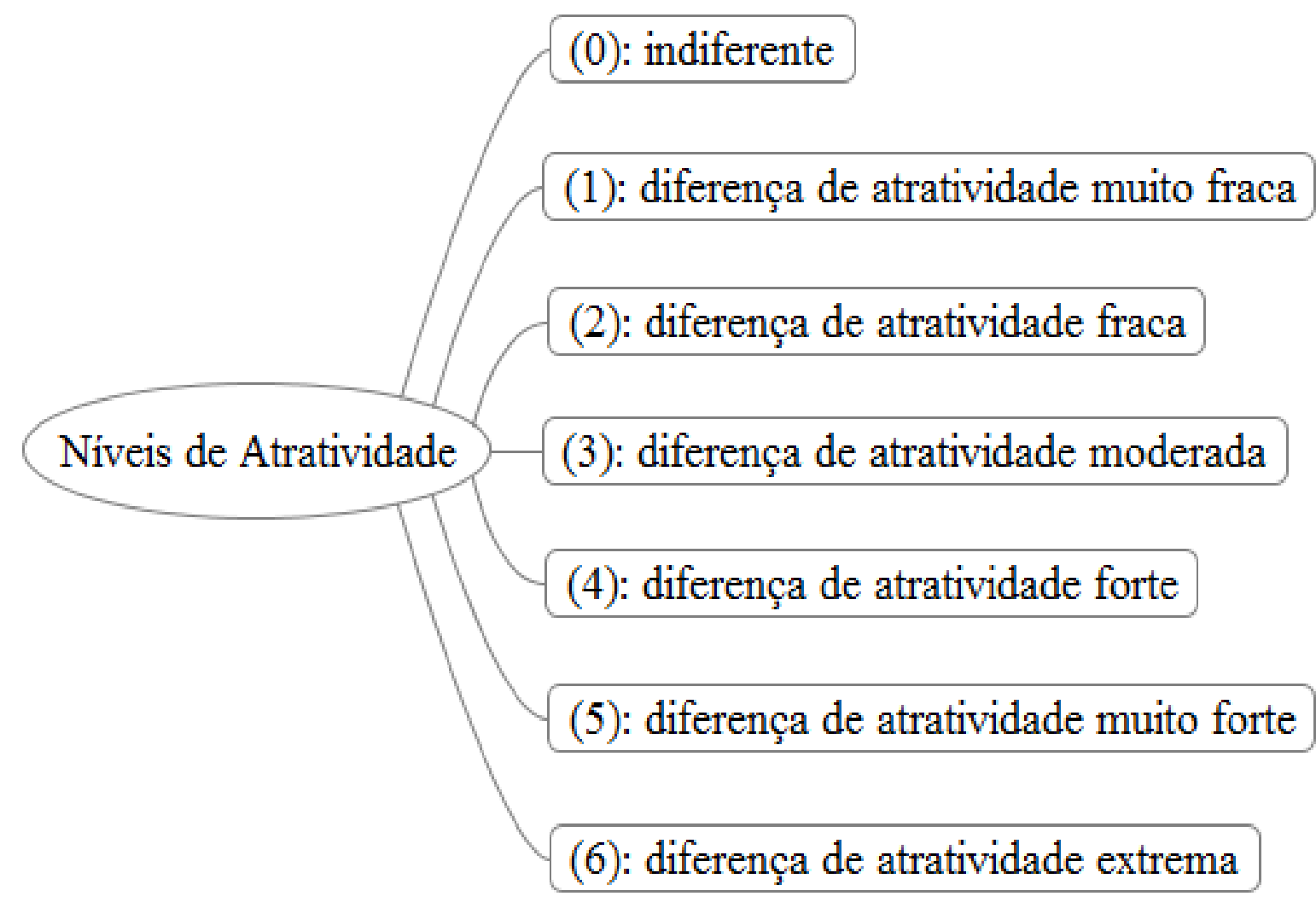

Figura 4.5 - Níveis de atratividade. Adaptado Bana e Costa (1995)

Segundo Bana e Costa (1995, p. 24), "MACBETH foi concebido para ser utilizado como um método interativo de apoio à construção de uma escala cardinal sobre um conjunto A de ações”. Matematicamente, o método Macbeth é composto de quatro programas lineares, Mc1 a Mc4, resolvidos sequencialmente (BANA E COSTA, 1995), conforme (Fig. 4.6).

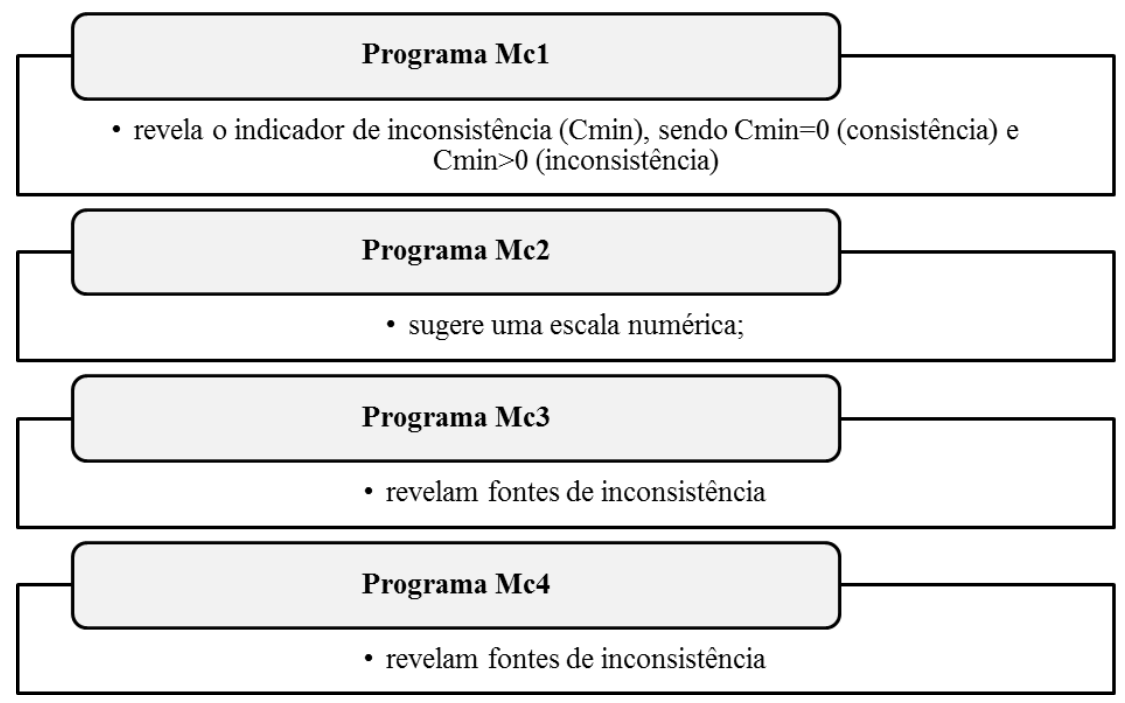

Figura 4.6 - Etapas de programação linear. Adaptado Bana e Costa (1995)

De modo prático, as agregações matemáticas são alcançadas por meio do software M-Macbeth, que operacionaliza a técnica de forma sistêmica. Por meio da aplicação do software, são 
efetivadas as apreciações de julgamento realizadas pelo decisor. Desse modo, com o uso da programação linear, o M-Macbeth oferece a escala de avaliação ou de notas e os intervalos em que as notas podem mudar sem que o problema fique inconsistente. (LONGARAY et al. 2010)

A seguir, é apresentada a concepção de um método multicritério de avaliação da política de mobilidade urbana. Foram escolhidas cinco diretrizes da Lei 12.587/2012 que tratam da PNMU para a utilização nas análises. A escolha, bem como a ordenação do grau de importância de cada uma, foi definida pelo pesquisador. De forma análoga, na aplicação prática do método proposto, o decisor deve ser o responsável por tais escolhas e ponderações frente à realidade local, como termômetro da estratégia política da pasta.

\subsection{MATRIZ DE AVALIAÇÃO - CRITÉRIOS DE AVALIAÇÃO}

O enquadramento do processo decisório é formado pelo conjunto de ações potenciais (as oportunidades de escolha) associado aos pontos de vista fundamentais dos decisores. Keeney (1992) apresenta uma discussão detalhada sobre este importante tópico. O conjunto de ações potenciais define quais são consideradas em uma situação decisória específica os Pontos de Vista Fundamentais (PVF), assim como apontam os valores que os decisores consideram importantes naquele contexto e, ao mesmo tempo, definem as características das ações que são de interesse dos decisores. (BANA E COSTA, 1992). A Fig. 4.7 apresenta a posição do Ponto de Vista (PV) no processo decisório.

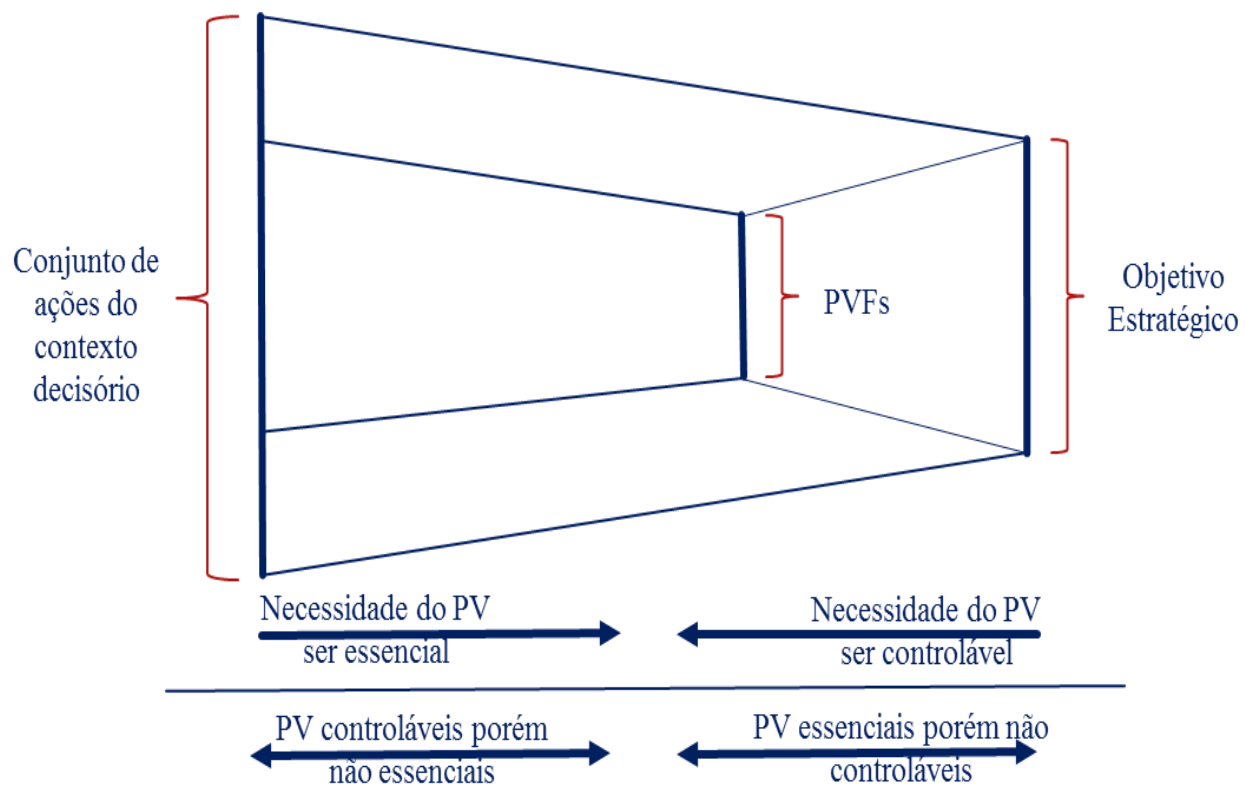

Figura 4.7 - Enquadramento do PV no processo decisório - Fonte: Ensslin \& Montibeller (1998). 
Uma vez que todos os ramos do mapa estejam enquadrados, Lima (2003) informa que o passo seguinte é representar os candidatos a pontos de vista de uma forma que aumente a compreensão dos aspectos a serem avaliados no conjunto de ações potenciais. Nesse sentido, a Fig. 4.8 apresenta de forma simplificada a Árvore de Pontos de Vista a ser desenvolvida.

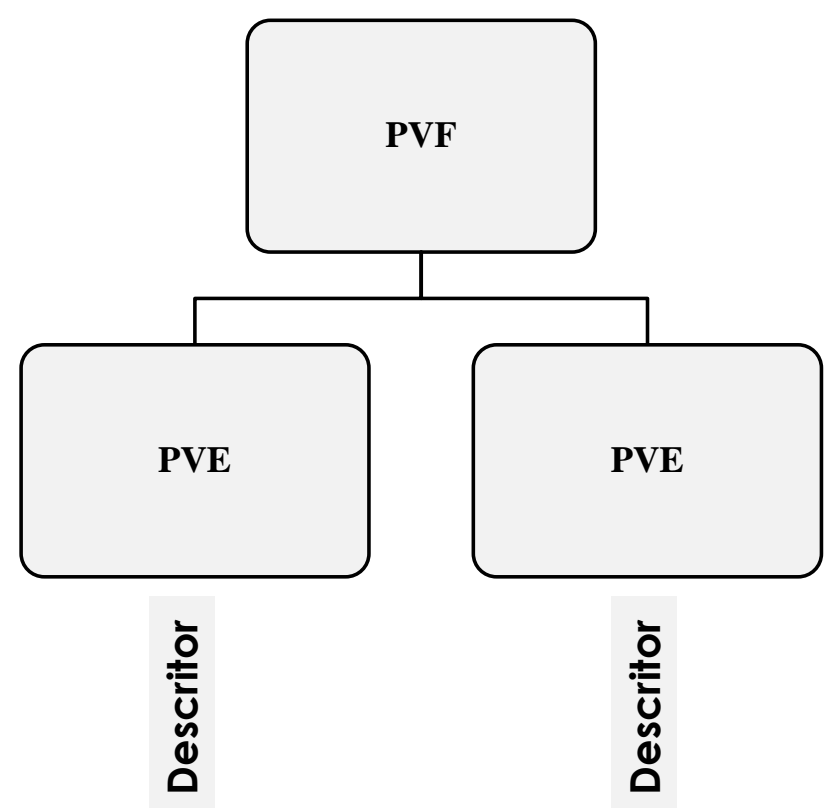

Figura 4.8 - Árvore de Pontos de Vista. Adaptado de Ensslin \& Montibeller (1998)

O modelo de avaliação proposto tem a finalidade de analisar aspectos estruturais da Lei 12.587/2012, considerados fundamentais ao bom desempenho da PNMU, no que tange à aplicação da lei por meio da gestão estratégica na esfera municipal. Para isso foram criados cinco Critérios de Avaliação, assim chamados de PVFs, extraídos da Lei de Mobilidade, e definidos de forma própria pelo pesquisador em consonância com a lei. Assim demonstra a Fig. 4.9: 


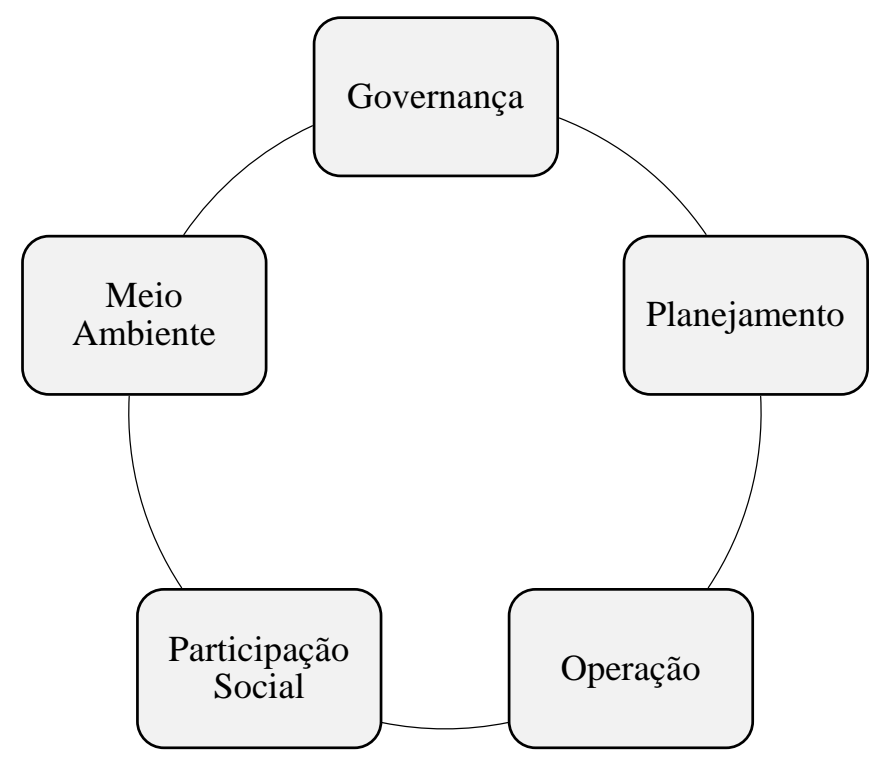

Figura 4.9 - Critérios de Avaliação: PVFs e PVEs. Elaboração própria

A governança está associada a uma transformação da gestão política, ou seja, corresponde à capacidade da gestão pública de produzir bens públicos, em conjunto com atores externos e internos ao ambiente do município. Denota a disposição em buscar alianças para o fortalecimento das ações de mobilidade urbana em espaço local. Nesse contexto, dada a relevância de mudar o status quo, corresponde a fatores críticos de sucesso ao emprego da PNMU.

O Planejamento é definido aqui como sendo a relação da preparação, organização e estruturação dos projetos e planos para atingir os objetivos pretendidos da PNMU em âmbito municipal. É uma forma de guiar o processo de tomada de decisão, ao passo que assinala para a sociedade os alvos a serem perseguidos pela PMU em médio e longo prazos. Também constitui mecanismos de controle da gestão estratégica do município, ao permitir confrontar o planejado versus o executado.

A Operação corresponde à capacidade do município de se portar frente às demandas específicas e rotineiras da PMU. São ações de curto prazo, embasadas por planos detalhados de execução, especificando as pessoas envolvidas, suas responsabilidades, atividades, funções e divisão de tarefas. Enfatiza a maneira como é recebido o planejamento estratégico e o grau de alinhamento com o resultado pretendido. Além disso, evidencia a forma de o município tratar suas demandas de emergência e seu contingenciamento.

O Meio Ambiente revela a visão do município quanto às premissas de sustentabilidade ambiental inseridas na Lei de Mobilidade Urbana. Determina como a gestão estratégica traça 
seus planos de mobilidade inserindo mecanismos de controle de poluição e outras práticas de combate a vetores poluentes e nocivos a sociedade. Revela qual a prioridade dada às ações no sistema de transporte, com o intuito de evitar grande incidência na morbidade da população urbana, pela poluição e pelos acidentes.

A Participação Social é colocada aqui como importante instrumento de política pública contida na Lei 12.587/2012, que confere ao município a obrigatoriedade de levar à luz da sociedade a discussão dos Planos de Mobilidade de forma ampla e democrática. A Participação Social é uma extraordinária ferramenta para avaliar a gestão estratégica do município, principalmente na etapa de formulação das políticas, pois busca dar clareza ao processo de tomada de decisão, diante de uma agenda mais próxima ou distante dos anseios da sociedade.

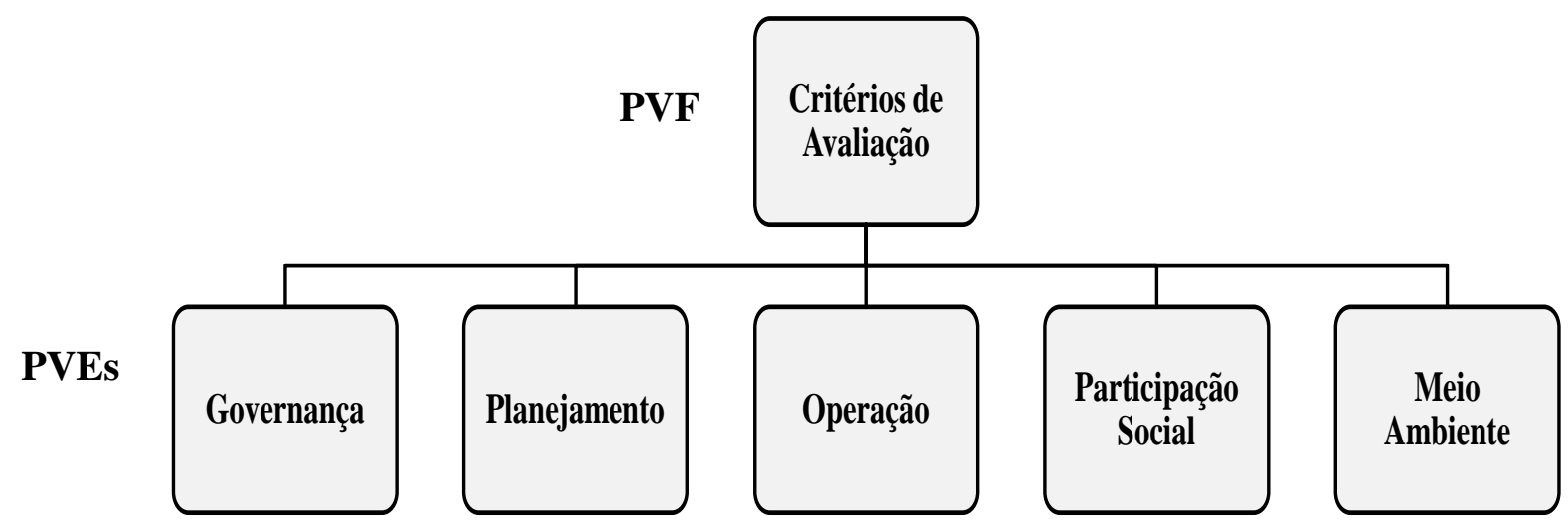

Figura 4.50 - PVFs e PVEs. Elaboração própria

As questões das avaliações (Critérios de Avaliação) foram fundamentadas com base nos artigos da Lei 12.587/2012, conforme apresentado na Fig. 4.11. 


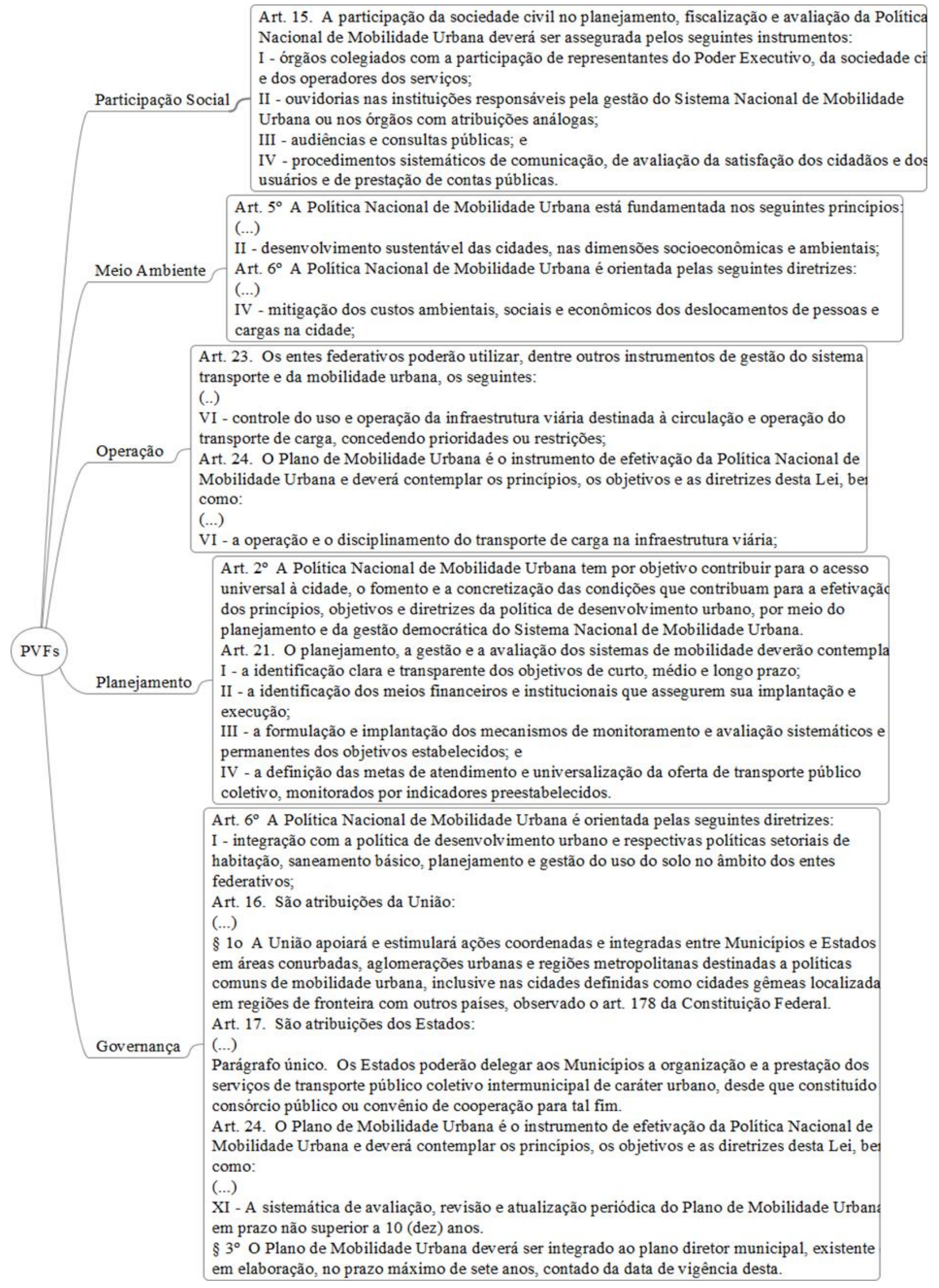

Figura 4.61 - Fundamentos dos critérios de avaliações a partir da Lei 12.587/2012. Elaboração própria. 


\subsection{MATRIZ DE PREFERÊNCIA}

O critério de avaliação adotado neste trabalho foi o da eficiência (como princípio da Administração Pública), pois se busca avaliar o grau de eficiência da execução da PNMU pelo ente municipal, admitindo-se que a responsabilidade de atingir os objetivos da política pública em questão é do gestor público na figura do decisor. De forma geral, a consolidação da estratégia adotada pelo decisor, baseada nos cinco Critérios de Avaliação, perfaz a avaliação do município no que tange à aplicação da PMU.

Após a construção dos Critérios de Avaliação, busca-se extrair do decisor, por meio de entrevista, a construção do quadro de preferência entre os norteadores apontados e explicados durante o processo de entrevista, com duração média de uma hora. A montagem da matriz de preferência é realizada concomitantemente com a entrevista, a partir da exposição da preferência do decisor quando comparados os critérios, como apresentado na Fig. 4.12.

\begin{tabular}{|c|l|l|l|l|l|l|}
\hline & Governança & Planejamento & Operação & $\begin{array}{c}\text { Participação } \\
\text { Social }\end{array}$ & $\begin{array}{c}\text { Meio } \\
\text { Ambiente }\end{array}$ & Peso \\
\hline Governança & & & & & & \\
\hline Planejamento & & & & & & \\
\hline Operação & & & & & & \\
\hline $\begin{array}{c}\text { Participação } \\
\text { Social }\end{array}$ & & & & & & \\
\hline Meio Ambiente & & & & & & \\
\hline
\end{tabular}

Figura 4.72- Montagem da Matriz de Preferências. Elaboração própria

Cabe destacar que esta fase do estudo busca identificar caminhos e formular procedimentos para medições posteriores. Para a construção do modelo, três inserções de dados são feitas na metodologia:

- $\quad$ etapa do pesquisador/facilitador: indicação dos Critérios de Avaliação;

- $\quad$ etapa do decisor: aquele responsável pela decisão estratégica do órgão de mobilidade, atua na valoração da matriz de preferência;

- $\quad$ etapa dos gestores/executores: aplicação de questionário para avaliar a sinergia entre a estratégia e a execução dentro dos Critérios de Avaliação apresentados.

Definidos os Critérios de Avaliação, a definição do descritor passa a ser elemento vital na pesquisa. Segundo Ensslim (2001, p.162), “o número de níveis de impacto de um descritor deve 
ser em torno de cinco e a escolha dos limites superior e inferior deve ser cuidadosa: o melhor nível deve ser aquele considerado pelos decisores como o melhor viável. Já o pior nível é aquele considerado como o pior admissível”. Ainda segundo Ensslim (2001, p.163), “a etapa de construção dos descritores é uma das que mais influenciam na qualidade do modelo multicritério, portanto requer dedicação e perseverança por parte do facilitador”. A Fig 4.13 apresenta a criação do descritor e seus níveis de impacto utilizado na metodologia.

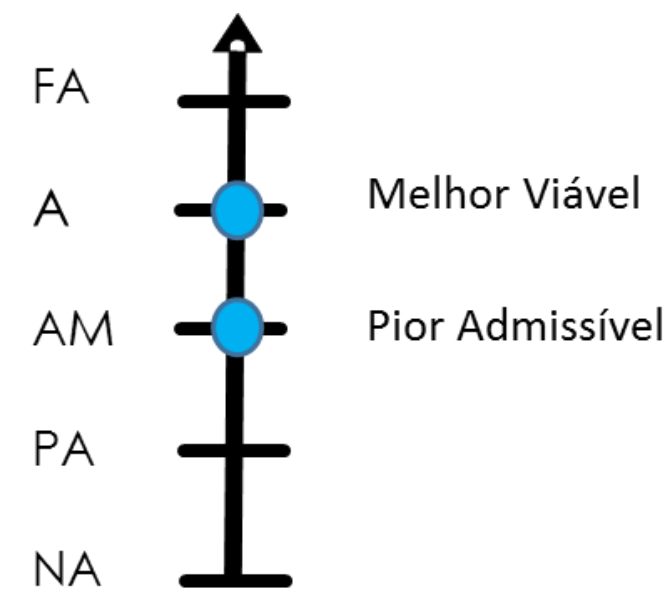

Figura 4.83 - Descritor e seus níveis de impacto. Adaptado Ensslin (2001)

O questionário final é composto de questões sobre cada Critério de Avaliação, definidas no formato simplificado, mostrando os descritores envolvidos, como mostra de forma resumida a Fig. 4.14, onde: Fortemente Aplicado-FA; Aplicado - A; Aplicação Moderada-AM; Pouco Aplicado-PA; Nenhuma Aplicação-NA. 


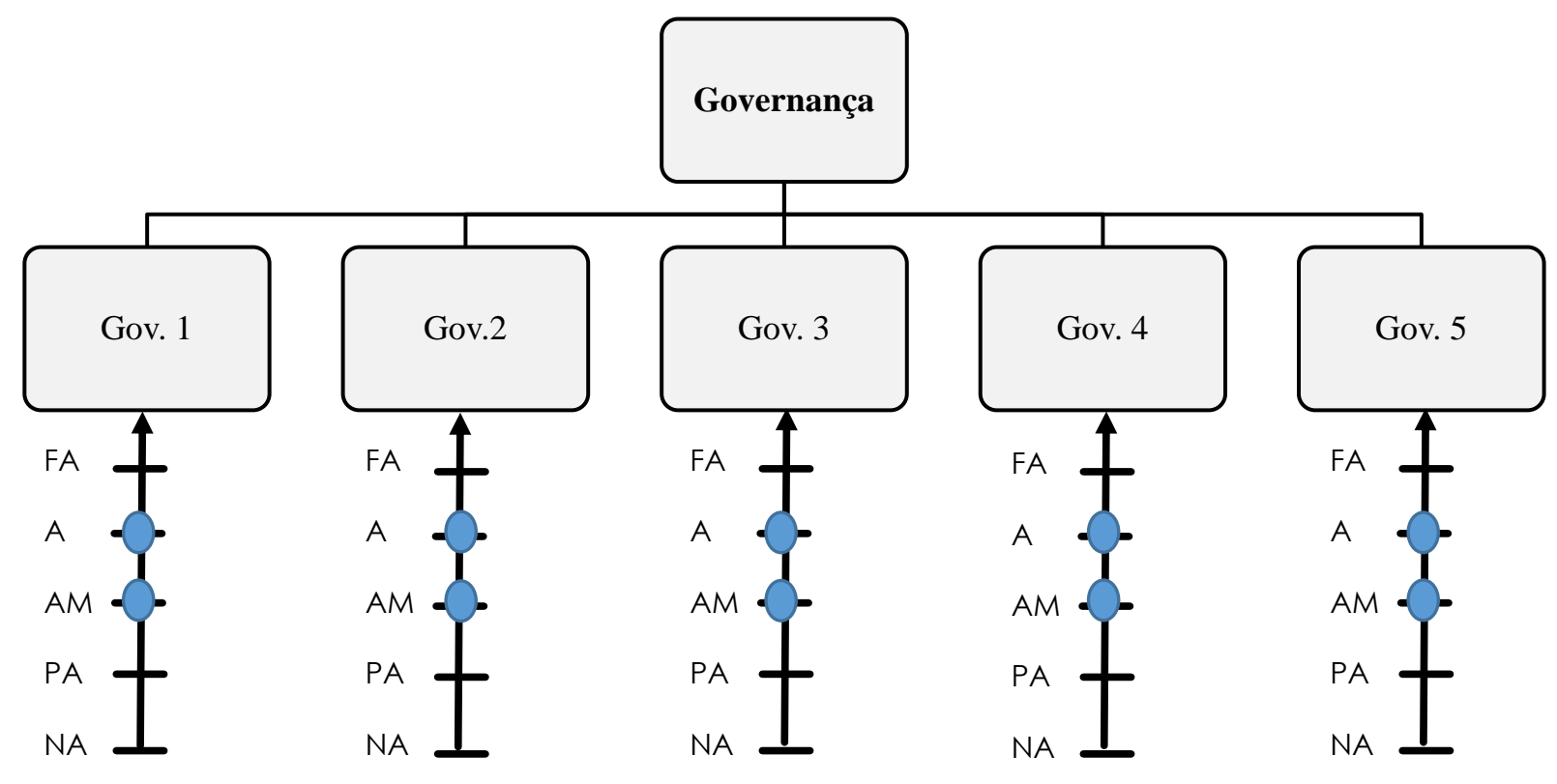

Figura 4.94 - Critérios de avaliação. Elaboração própria

Para decompor o eixo de avaliação, é necessário identificar pontos de vista elementares. (BANA E COSTA, 1992) "Os Pontos de Vistas Elementares (PVE) decompõem um PVF, permitindo uma melhor avaliação da performance das ações potenciais no ponto de vista considerado. Com isso, eles permitem uma maior compreensão do que um Ponto de Vista Fundamental pretende levar em conta”. (ENSSLIM 2001).

A título de exemplo, a Fig. 4.15 demonstra a decomposição do eixo de avaliação do critério Governança, como forma de aplicação do PVF, dos PVFs e dos descritores envolvidos na avaliação metodológica. Nesse sentido, (A): aplicado, corresponde ao nível BOM e (AM): atende moderadamente, corresponde ao nível NEUTRO. 


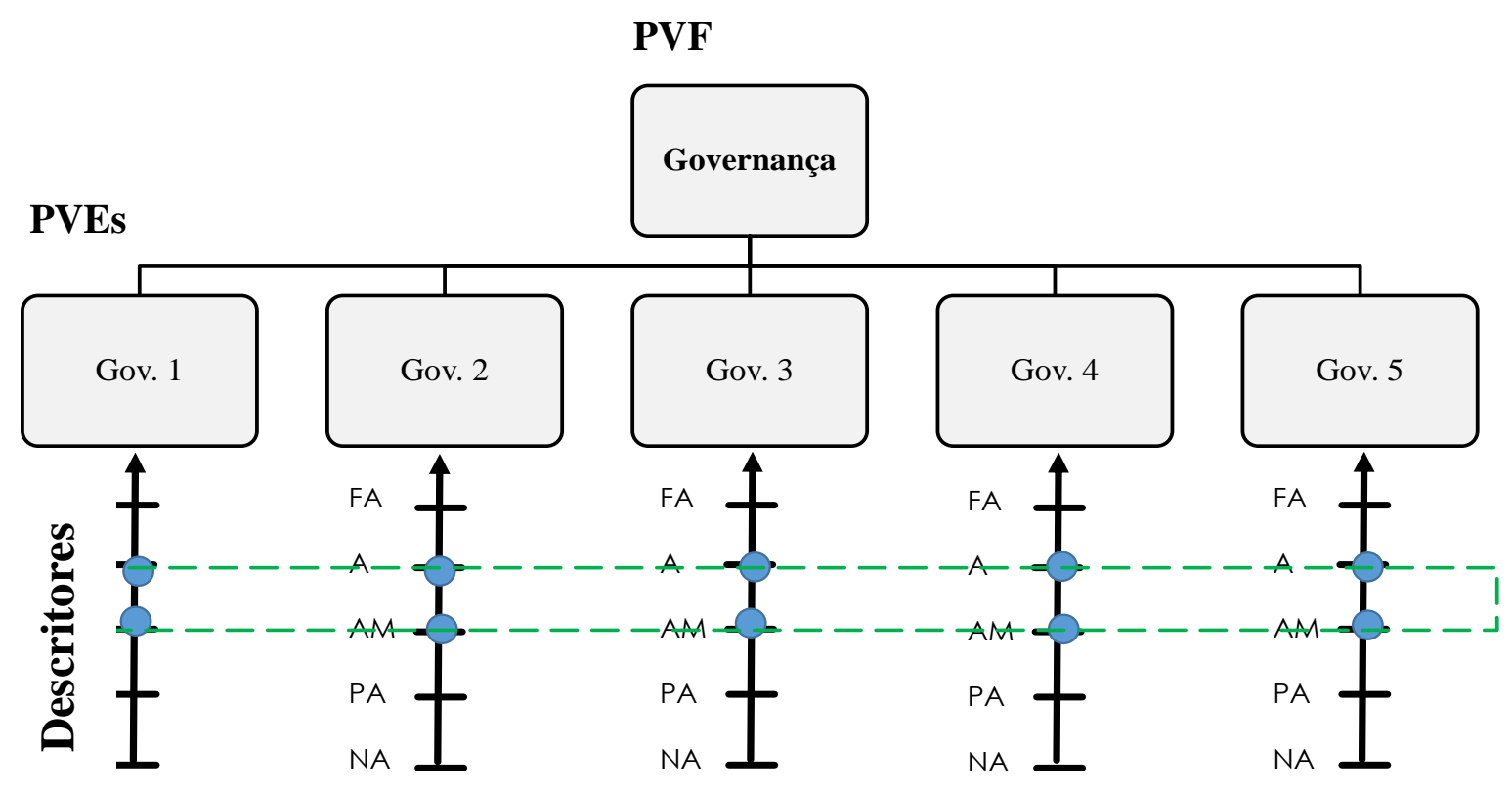

Figura 4.105 - Decomposição do eixo de avaliação do critério Governança. Elaboração própria.

Segundo Ensslim (2001), em um descritor bem construído, a maioria das ações normalmente tem sua performance no intervalo situada entre os níveis Bom e Neutro. Isso corre porque, de maneira geral, a maioria das ações existentes tem uma performance dentro das expectativas dos decisores, havendo ruins (abaixo do nível Neutro) e alguns excelentes (acima do nível Bom). Na Fig. 4.16, é apresentada a organização dos critérios de avaliação e a disposição da zona de admissibilidade, construída a partir da percepção do decisor. 


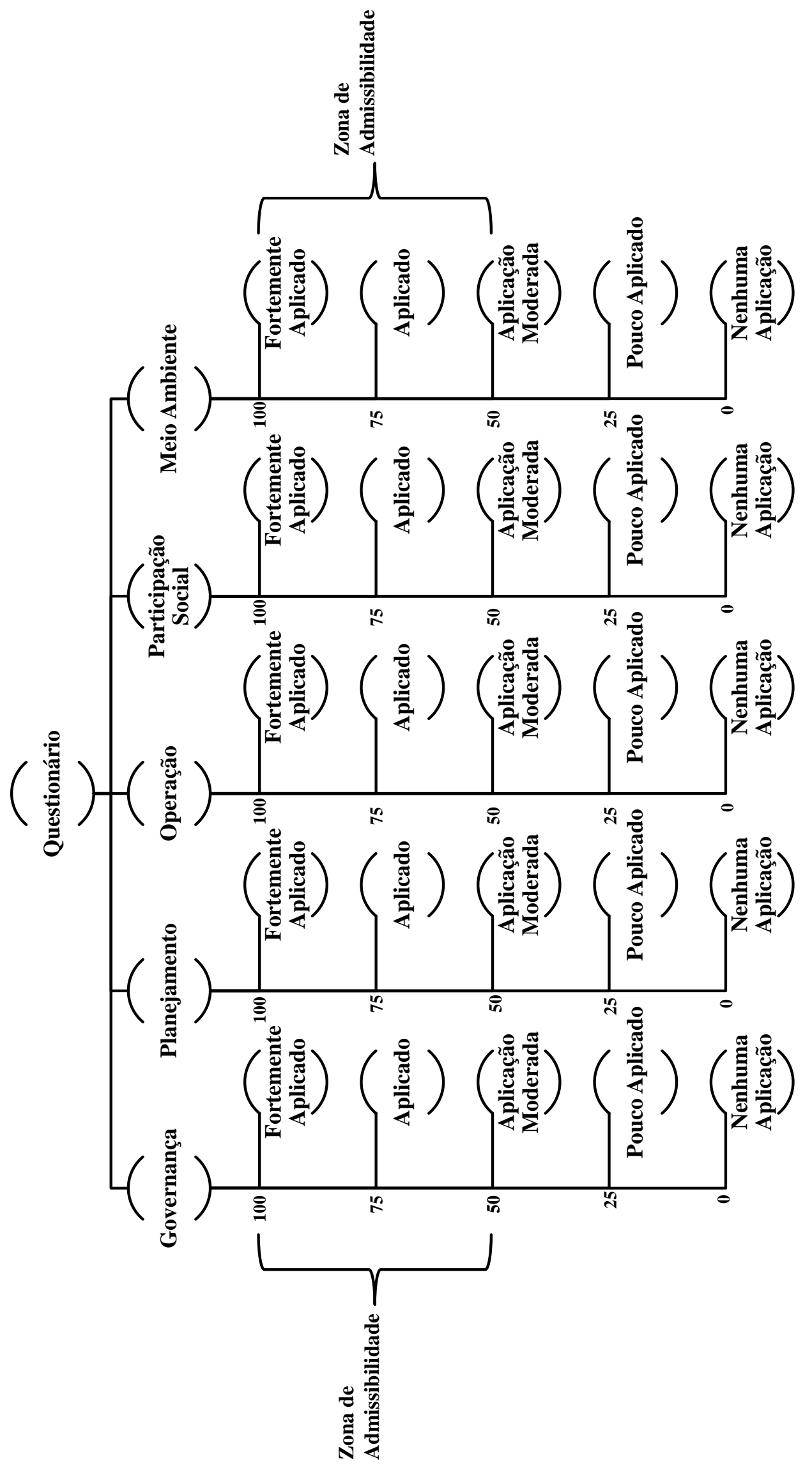

Figura 4.116 - Organização dos critérios de avaliações e zona de admissibilidade. Elaboração própria. 


\subsection{DEFINIÇÃO DAS OPÇÕES COMPARÁVEIS}

Neste tópico, são apresentados os passos iniciais na utilização do programa M-Macbeth. Na Fig. 4.17, é apresentado o quadro de opções comparáveis, as quais consistem nos agentes envolvidos no estudo, que são cinco gestores responsáveis pelo processo de execução da PMU. O decisor como sendo a autoridade política do município com atribuições diretamente relacionadas à Política de Mobilidade Urbana, e os gestores, os dirigentes/executores da política em questão.

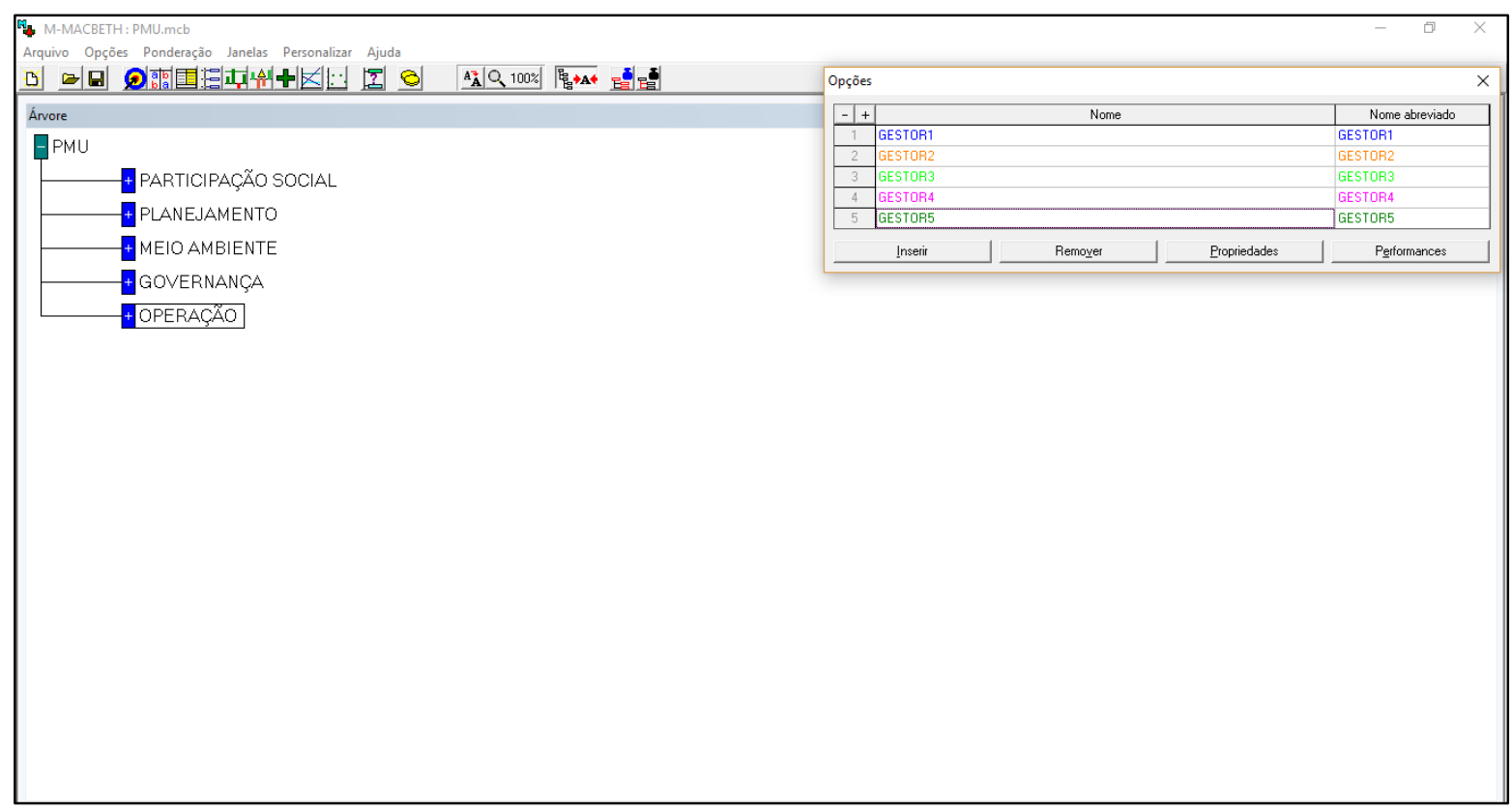

Figura 4.127 - Apresentação das opções comparáveis geradas no programa.

\subsection{ESTRUTURAÇÃO DA ÁRVORE DE PONTOS DE VISTA}

A árvore de pontos de vista consiste na estrutura do método avaliativo e é composta dos PVFs e dos PVEs. Os cinco critérios de avaliação (Fig. 4.18) constituem o grupo de PVFs que em seguida foram desdobrados em PVEs. Na Fig. 4.19, é apresentada a tela em que foram gerados os PVFs. 


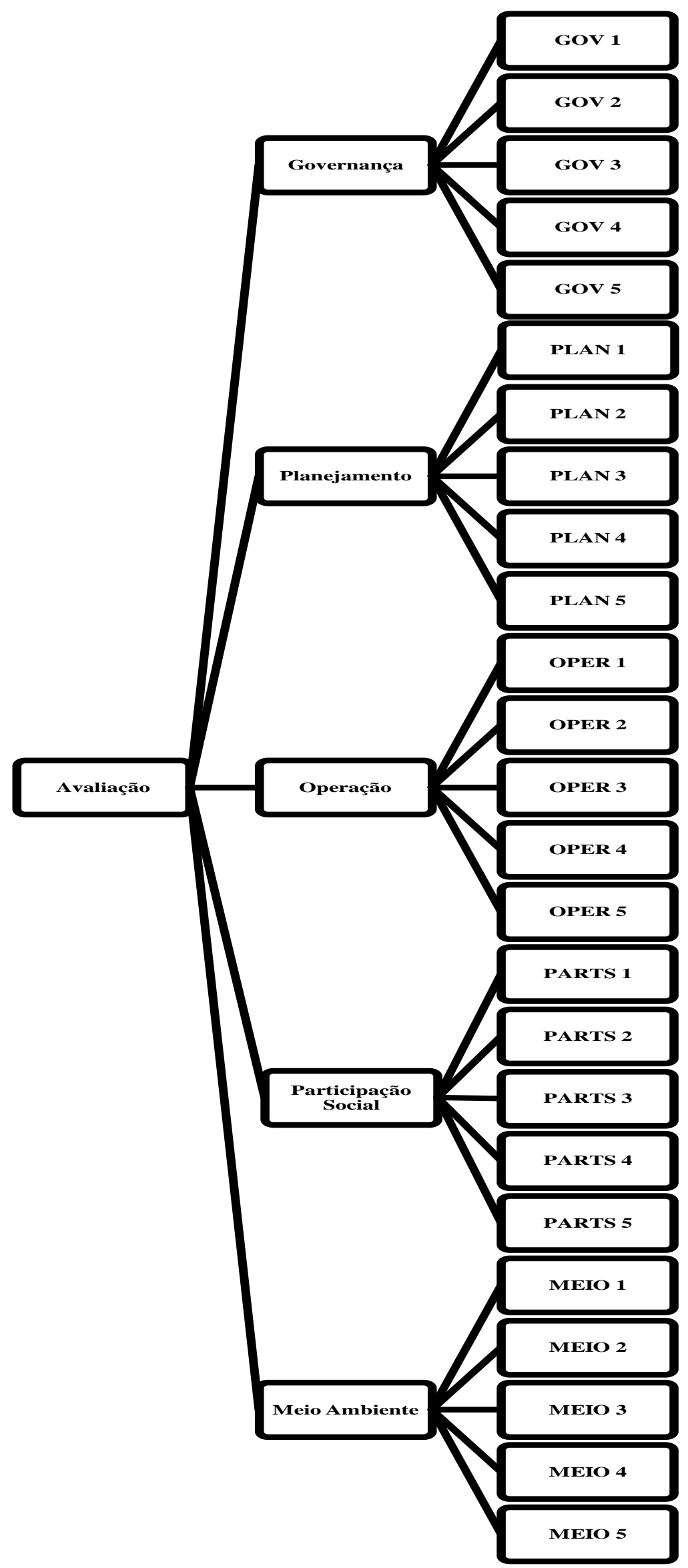

Figura 4.138 - Árvore de Pontos de Vista PVF e PVEs. Elaboração própria. 


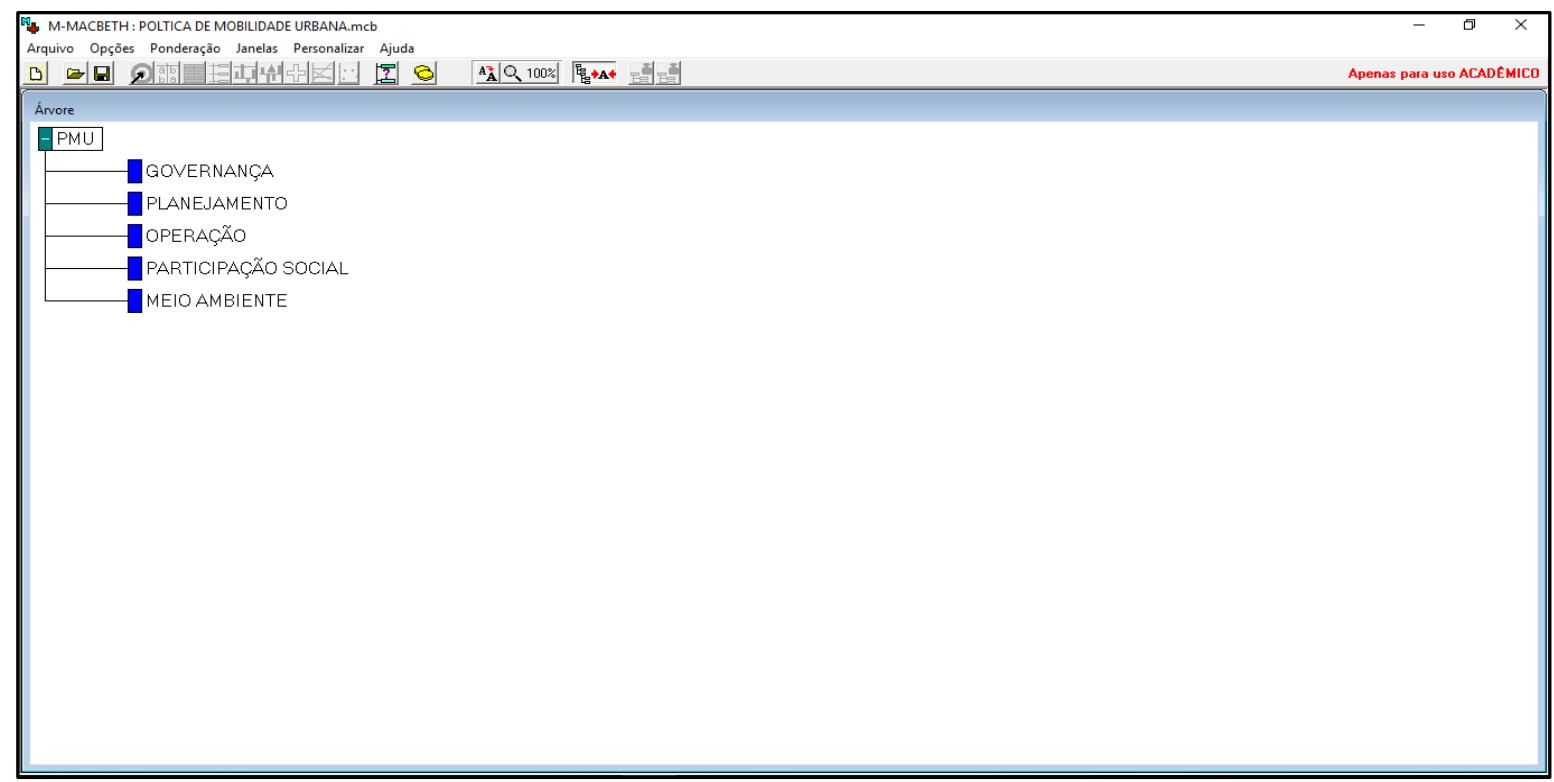

Figura 4.19 - Criação dos Pontos de Vista Fundamentais no M-Macbeth.

O conjunto de elementos PVFs e PVEs passa a compor o desenho esquemático do método de avaliação. Em destaque, cabe ressaltar que os PVEs correspondem à aplicação de questionário contendo perguntas elaboradas pelo pesquisador (Apêndice 1). Tais perguntas possibilitam julgar o grau de aplicação da política de mobilidade adotada em cada tema. Na Fig. 4.20, é apresentada a tela em que são criadas as propriedades de cada PVE, com cinco níveis qualitativos de respostas.

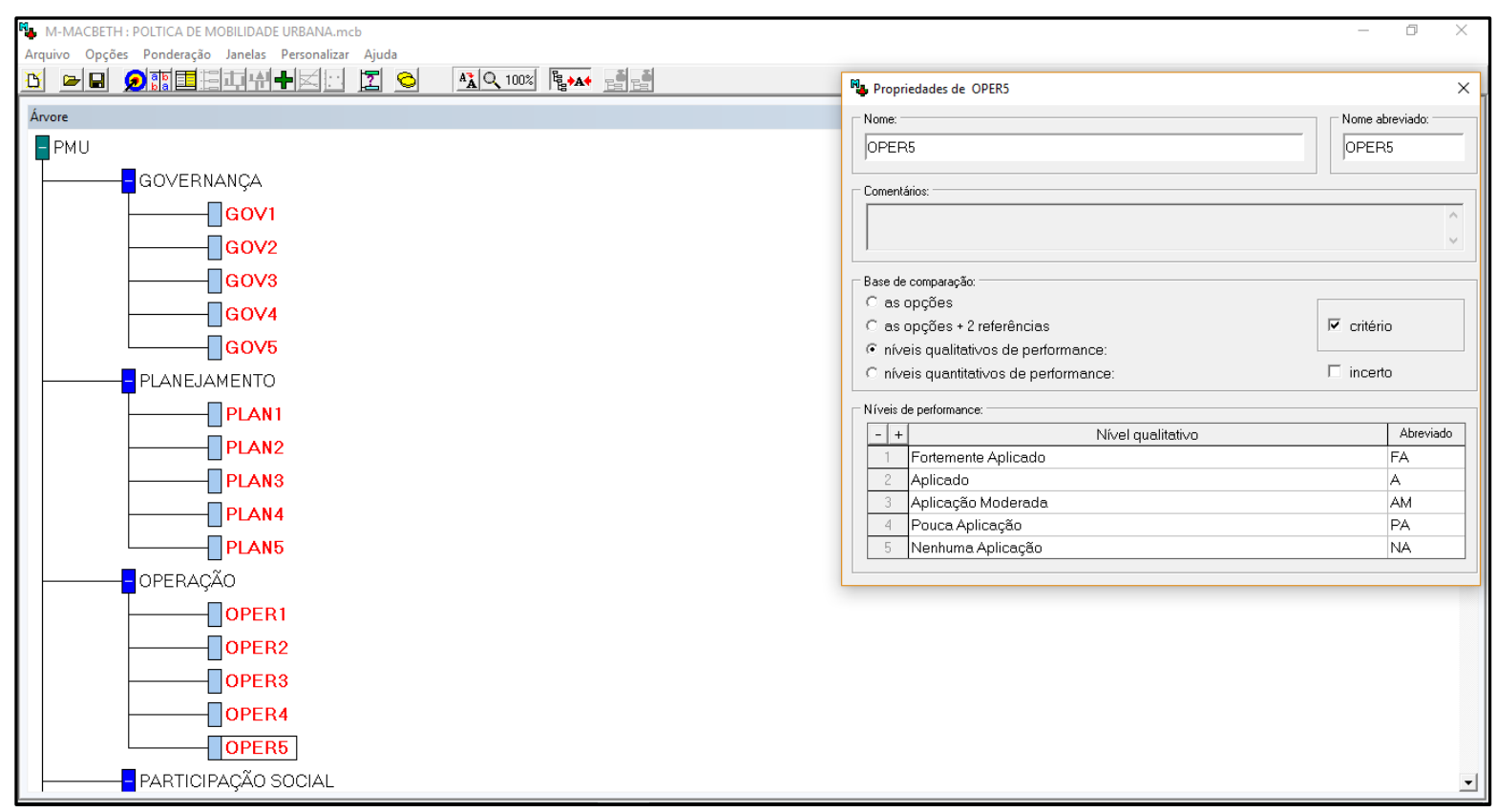

Figura 4.140 - Criação dos Pontos de Vista Elementares no M-Macbeth 


\subsection{VALIDAÇÃO DOS JULGAMENTOS}

Cada PVE deve ter seus atributos qualitativos validados pelo programa. A validação ocorre ao se atribuírem diferenças de atratividade para cada nível de resposta. Como exemplo, entre a marcação da opção "Fortemente Aplicado (FA)" para as demais opções, "Aplicado (A)", "Aplicação Moderada (AM)", "Pouca Aplicação (PA)" e "Nenhuma Aplicação (NA)", os julgamentos definidos quanto a diferença de atratividade foram: "fraca", "moderada", "forte" e "muito forte”. Na Fig. 4.21, é possível observar a situação descrita.

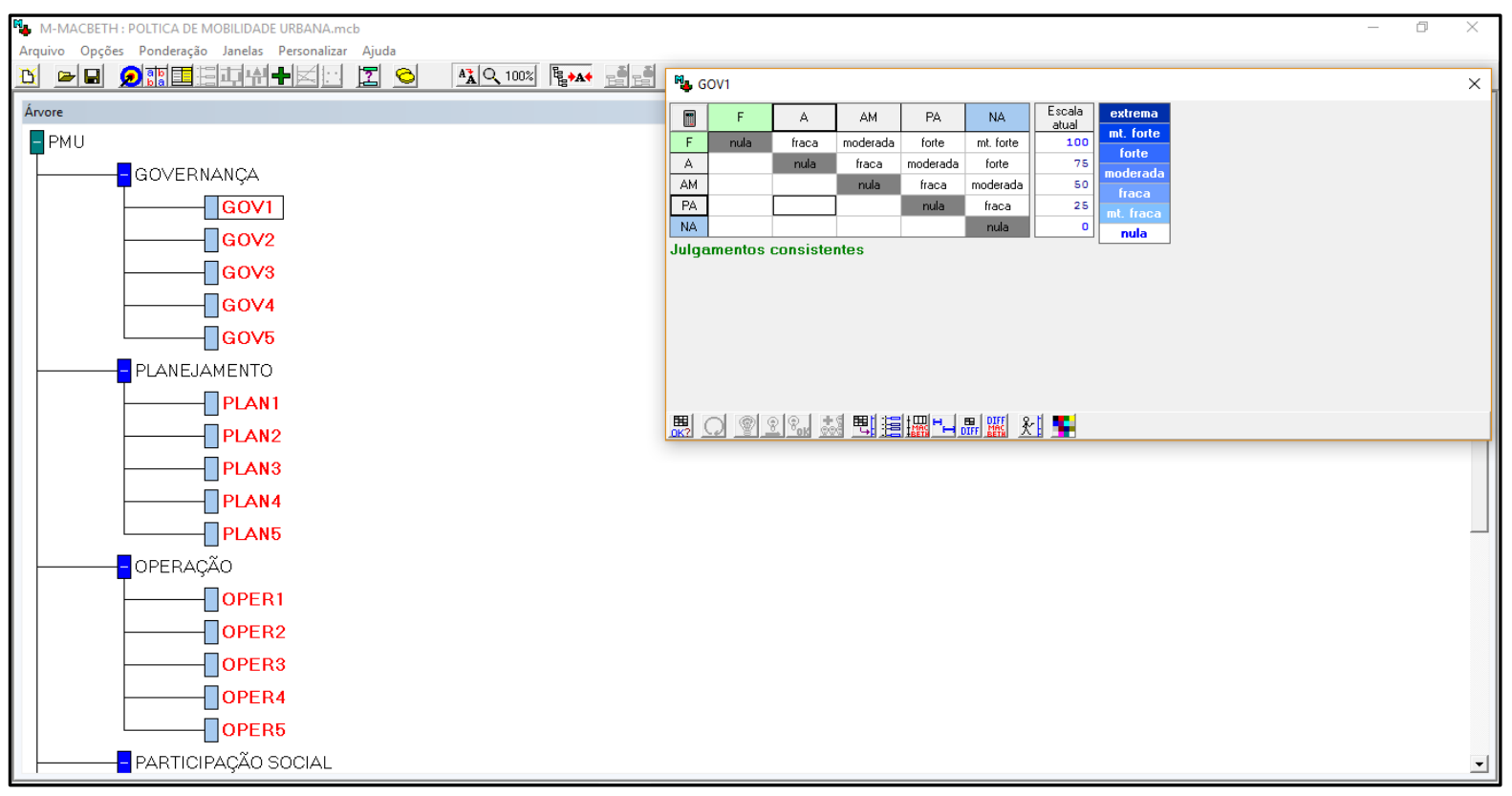

Figura 4.151 - Validação dos julgamentos dos PVEs

\subsection{ORDENAÇÕES CONFORME AVALIÇÃO DO DECISOR}

Como explicado anteriormente, o decisor deverá escolher, com base nas suas preferências políticas, quais PVFs possuem prioridades sobre os demais. Essa ordenação é operacionalizada no programa, dispondo os PVFs na coluna à esquerda, mostrada na Fig. 4.22. 


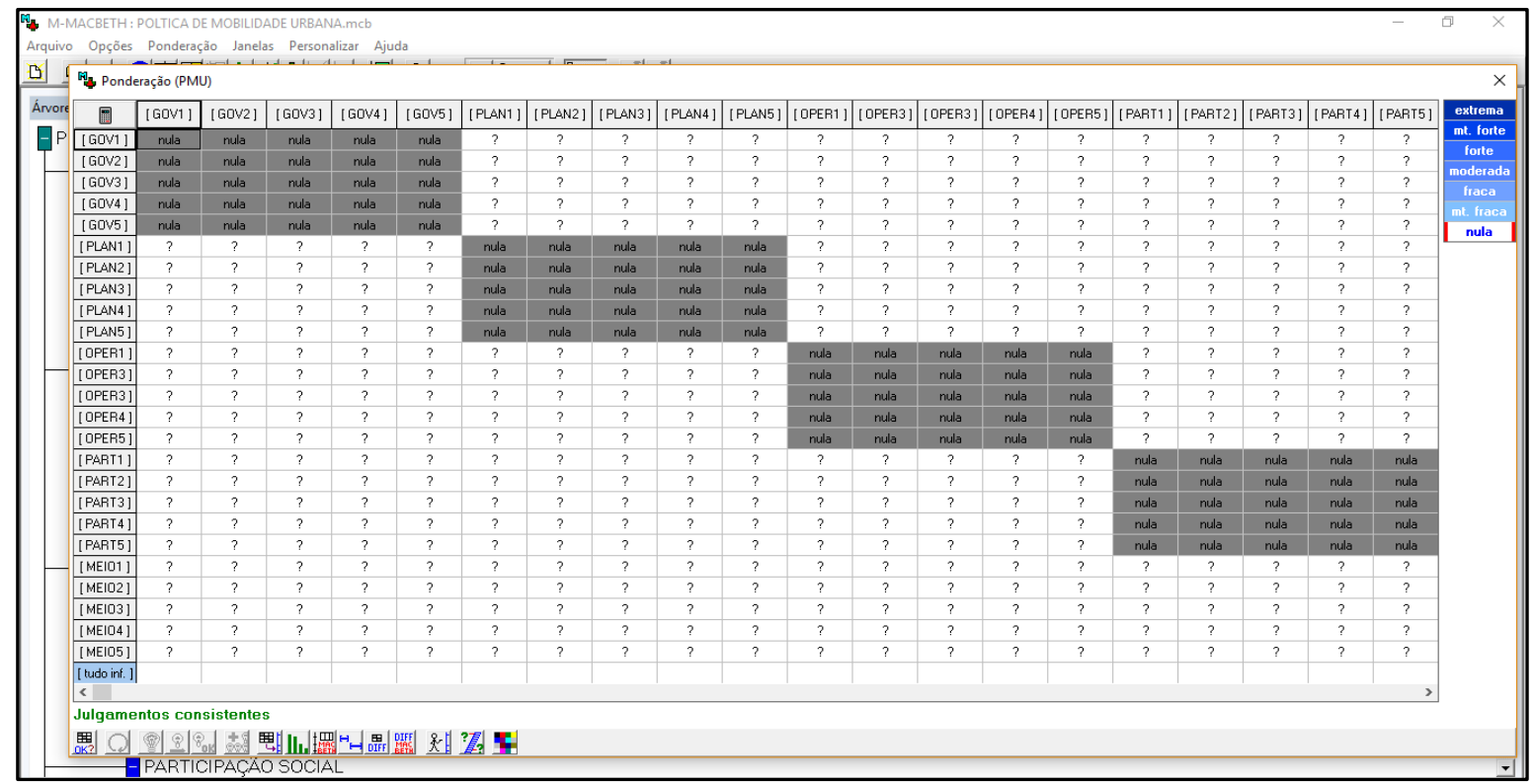

Figura 4.162 - Ordenação dos PVFs

\subsection{INSERÇÃO DE DADOS DAS AVALIAÇÕES QUALITATIVAS}

As avaliações preenchidas pelos gestores compõem, como explicado anteriormente, cada dado de PVE. Dessa forma, é preenchida a tabela de julgamentos, conforme apresentado na Fig. 4.23.

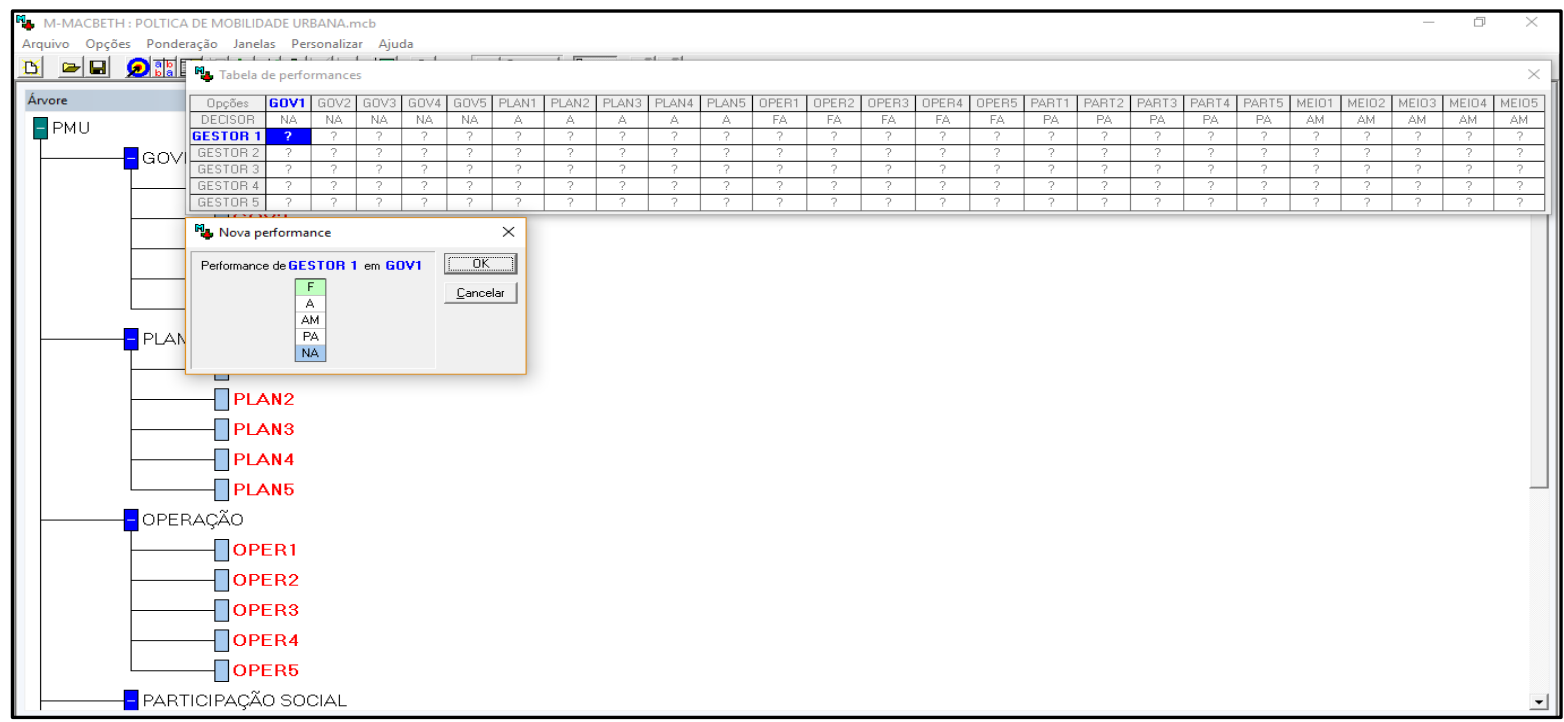

Figura 4.173 - Inserção de dados dos PVEs 


\subsection{OBTENÇÃO DE RESULTADOS E GRÁFICOS}

Concluídas todas as etapas anteriores, o programa M-Macbeth fornecerá diversas análises a partir da tabela de pontuações apresentada na Fig. 4.24. É possível obter diversas informações gráficas, como apresentado na Fig. 4.25, que mostra o "perfil de avaliações de um gestor"; e na Fig. 4.26, em que é mostrado um gráfico comparativo dos resultados das avaliações dos gestores da PMU local.

\begin{tabular}{|c|c|c|c|c|c|c|c|c|c|c|c|c|c|c|c|c|c|c|c|c|c|c|}
\hline \multicolumn{23}{|l|}{ | } \\
\hline Oppóes & bal & PARTS1 & \begin{tabular}{|l|l} 
PAATS2 \\
\end{tabular} & \begin{tabular}{|l|} 
PARTS3 \\
\end{tabular} & \begin{tabular}{|l|} 
PARTS4 \\
\end{tabular} & PARTS5 & \begin{tabular}{|l|} 
PLAN1 \\
\end{tabular} & PLAN2 & PLAN3 & PLAN4 & PLAN5 & MEl01 & ME102 & MEl03 & MEl04 & MEl05 & GOV1 & GOV/2 & GON/3 & $10 \times 4$ & G015 & 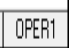 \\
\hline GESTOR1 & 78.00 & 75.00 & 100.00 & 75.00 & 50.00 & 75.00 & 75.00 & 100.00 & 75.00 & 75.00 & 100.00 & 75.00 & 75.00 & 100.00 & 75.00 & 50.00 & 100.00 & 0.00 & 75.00 & 0.00 & 100.00 & \\
\hline STOR2 & 4 & 00 & 00 & 100.00 & 50.00 & .00 & 50.00 & 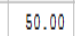 & no & 50.00 & 75.00 & 100.00 & 50.00 & .00 & 50.00 & 100.00 & .00 & .00 & .00 & .00 & & \\
\hline STOR & & 10 & & 0 & 100.00 & & 50.00 & & & & 10 & & & & & .00 & & 00 & 00 & & & \\
\hline STOR & & & .00 & 50.00 & 00 & 75. & 50.00 & 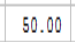 & 100.00 & 0 & 100.00 & 14 & 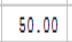 & 1 & .00 & 0.00 & & 75.00 & & 75.00 & 00 & \\
\hline GESTOR5 & & 5.00 & & 75.00 & 50.00 & 25.00 & 75.00 & 50.00 & 100.00 & 1.00 & 50.00 & 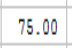 & 50.00 & 100.00 & 50.00 & 100.00 & 75.00 & 100.00 & 25.00 & 100.00 & 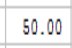 & \\
\hline did sup. & .00 & 100.00 & 100.00 & 100.00 & 100.00 & 100.00 & 100.00 & 100.00 & 100.00 & 100.00 & 100.00 & 100.00 & 100.00 & 100.00 & 100.00 & 100.00 & 100.00 & 100.00 & 100.00 & 100.00 & 100.00 & 100 \\
\hline [ tudo inf. ] & 0.00 & 0.00 & 0.00 & 0.00 & 0.00 & 0.00 & 0.00 & 0.00 & 0.00 & 0.00 & 0.00 & 0.00 & 0.00 & 0.00 & 0.00 & 0.00 & 0.00 & 0.00 & 0.00 & 0.00 & 0.00 & 0.0 \\
\hline \multicolumn{2}{|l|}{ Pesoss } & 0.0720 & 0.0720 & 0.0720 & 0.0720 & 0.0720 & 0.0560 & 0.0560 & 0.0560 & 0.0560 & 0.0560 & 0.0400 & 0.0400 & 0.0400 & 0.0400 & 0.0400 & 0.0240 & 0.0240 & 0.0240 & 0.0240 & 0.0240 & 0.008 \\
\hline
\end{tabular}

Figura 4.184 - Tabela de pontuações gerada pelo programa

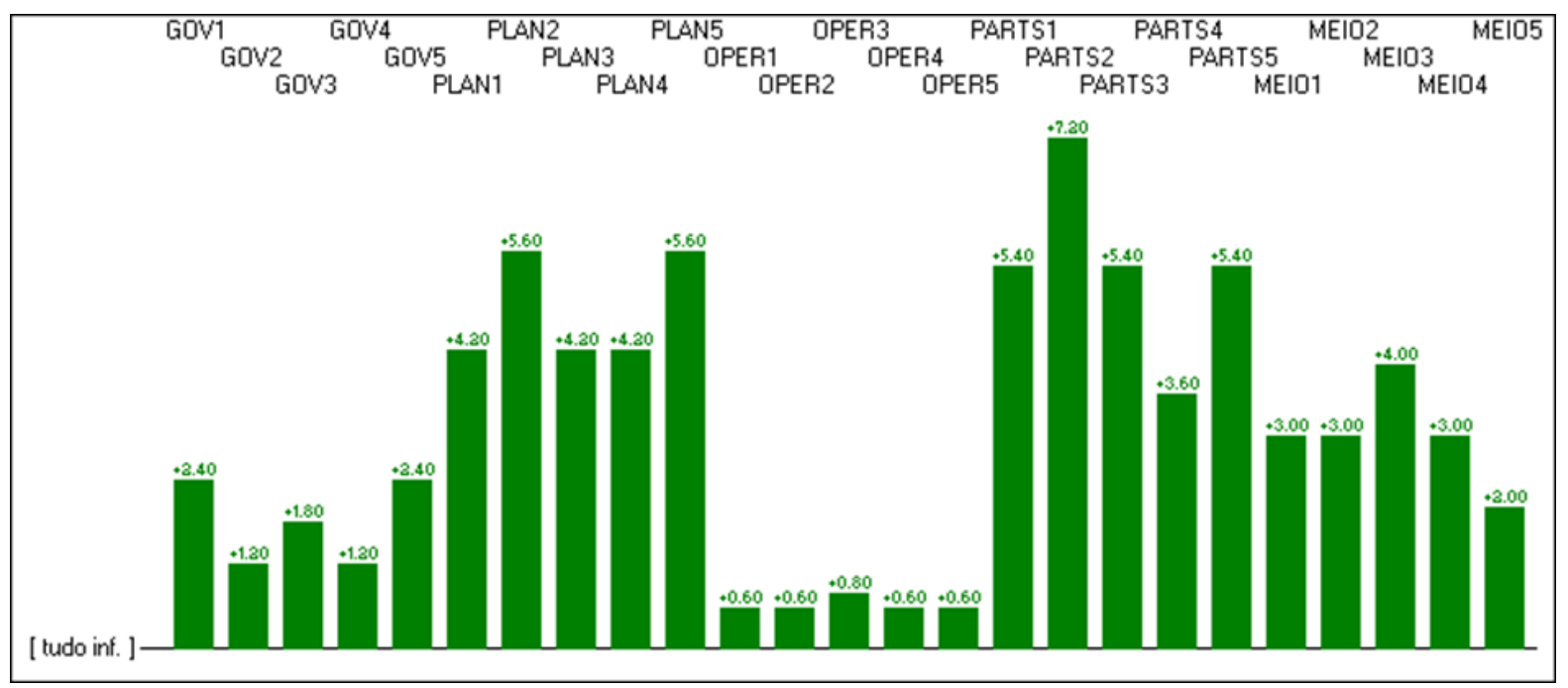

Figura 4.195 - Perfil de avaliações de um gestor. 


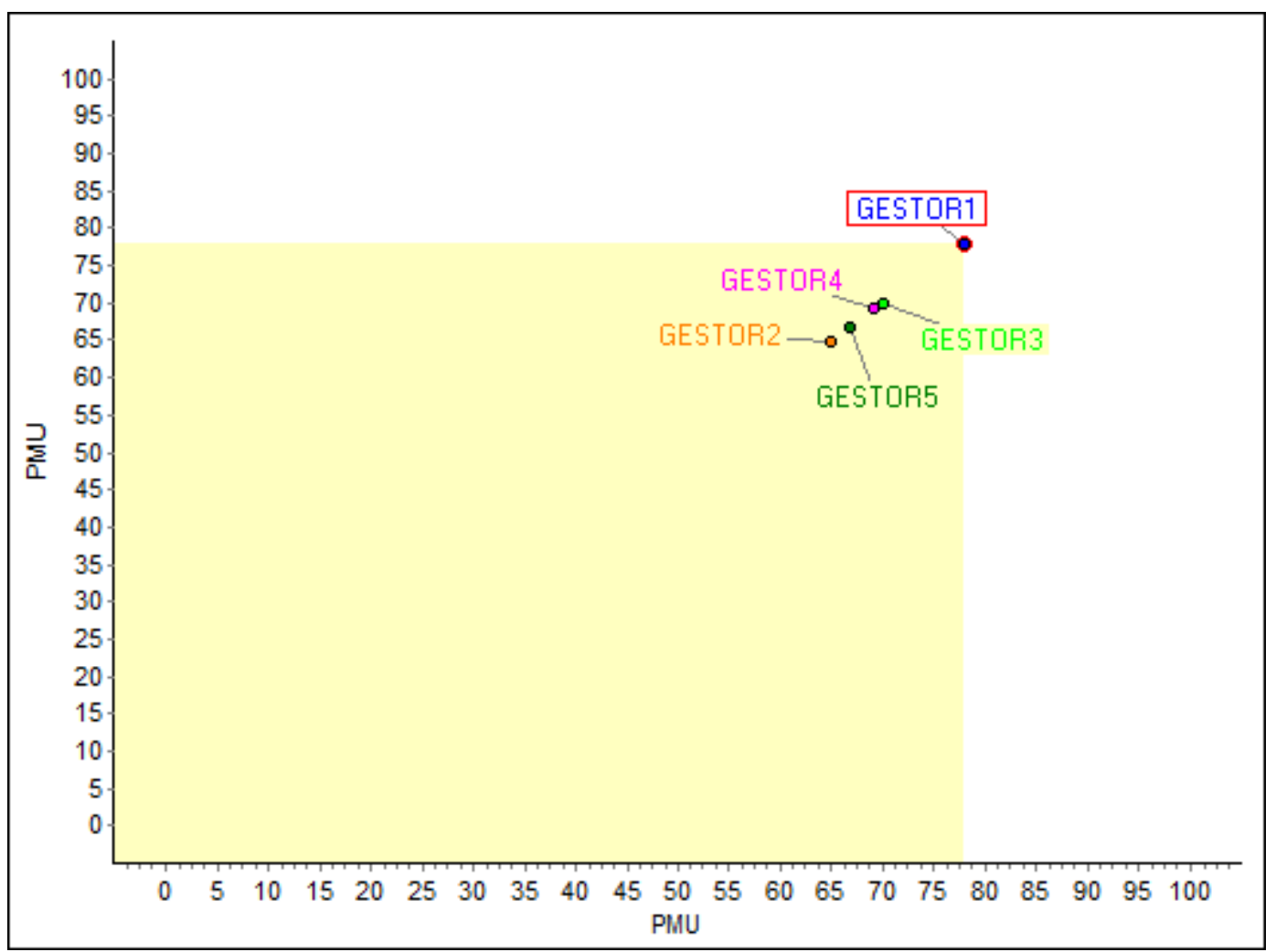

Figura 4.206 - Gráfico comparativo de resultados das avaliações da PMU

Em que pesem todas essas análises, o programa fornece também perfis de diferenças, que possibilitam verificar pontualmente as diferenças entre as ponderações do decisor e a situação real de aplicabilidade descrita pelos gestores. Um exemplo de perfil de diferenças é ilustrado na Fig. 4.27.

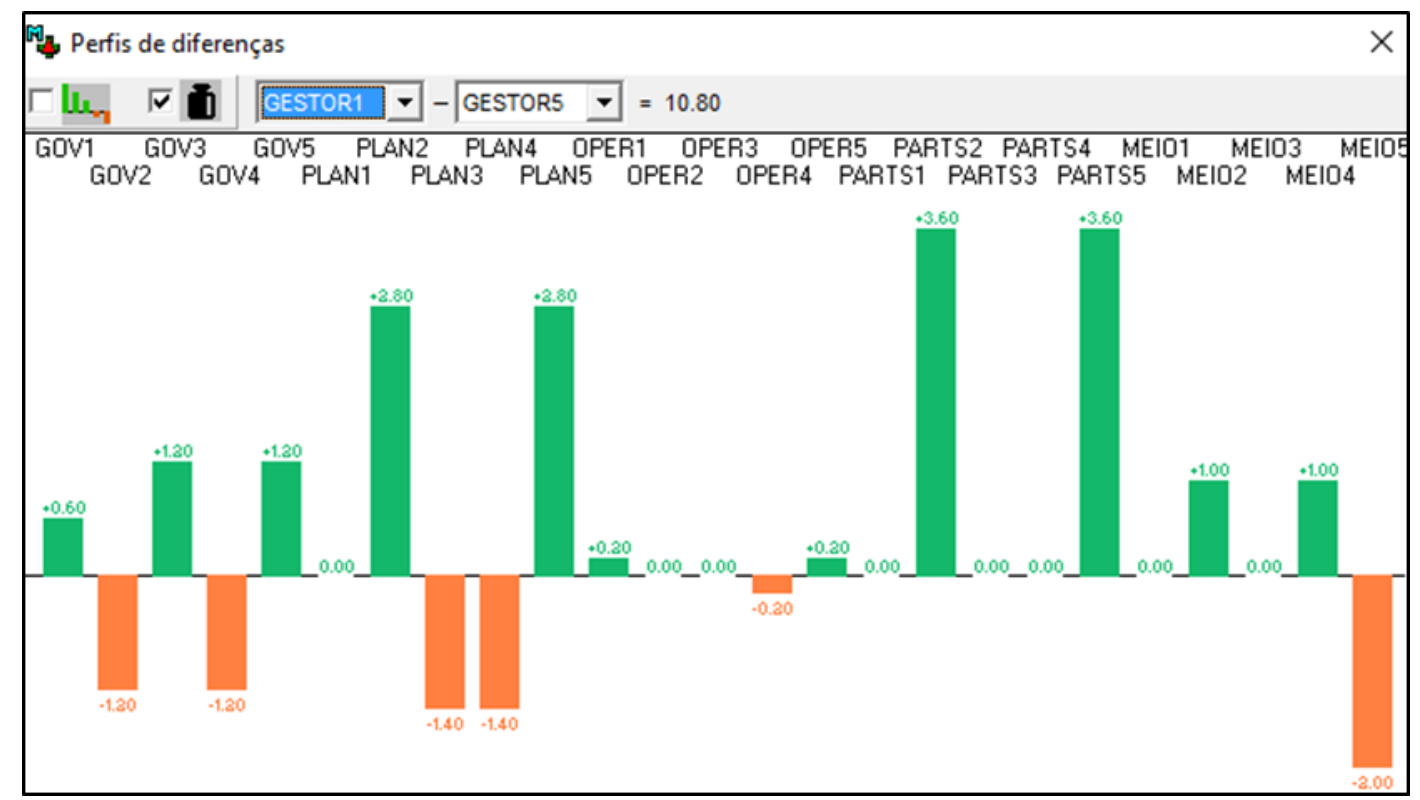

Figura 4.217 - Perfil de diferenças entre gestores. 


\section{APLICAÇÃO DO MÉTODO MULTICRITÉRIO DE AVALIÇÃO DA POLÍTICA DE MOBILIDADE URBANA}

Este capítulo apresenta a aplicação do método multicritério de avaliação da política de mobilidade urbana. Foram realizadas simulações de três cidades no modelo proposto. $\mathrm{O}$ objetivo consiste em obter um índice global para cada cidade, refletindo assim o nível de aplicabilidade da política em estudo. Para tal objetivo, dividiu-se o presente capítulo em: (a) Simulações; (b) Resultados, e (c) Índice de aplicabilidade da PMU.

Cabe destacar que neste capitulo, apenas o pesquisador/facilitador atuou. O intuito das simulações foi deixar evidente no trabalho o teste com o software M-Macbeth na ferramenta aqui desenvolvida, preparando o caminho para a aplicação da mesma em caso concreto no capítulo seguinte.

\subsection{SIMULAÇÕES}

Com o objetivo de analisar e observar o comportamento do programa em situações distintas de escolhas de prioridades de gestores, foram simuladas três cidades com as seguintes características:

- Cidade 1: o gestor atribuiu ao PVF Operação maior importância frente à realidade local e à disposição política, sendo o PVF Meio Ambiente o de menor relevância.

- Cidade 2: o gestor considera o PVF Meio Ambiente o de maior interesse no âmbito do município, sendo o PVF Participação Social considerado de menor deferência.

- Cidade 3: o gestor considera o PVF Participação Social o de maior relevância na escolha da política pública municipal, sendo ao PVF Planejamento atribuído menor atenção.

Neste sentido, inicialmente foram simuladas as características de três cidades distintas, com diferentes níveis de preferências de atuação na PMU. A estas foram atribuídas ordenações entre critérios, conforme apresentado na Tab. 5.1. 
Tabela 5.1 - Ordenação dos PVFs

\begin{tabular}{|c|l|c|l|c|l|}
\hline \multicolumn{2}{|c|}{ CIDADE 1 } & \multicolumn{2}{c|}{ CIDADE 2 } & \multicolumn{2}{c|}{ CIDADE 3 } \\
\hline ORDEM & \multicolumn{1}{|c|}{ PVF } & ORDEM & \multicolumn{1}{c|}{ PVF } & ORDEM & \multicolumn{1}{c|}{ PVF } \\
\hline 1 & Operação & 1 & Meio Ambiente & 1 & Participação Social \\
\hline 2 & Governança & 2 & Planejamento & 2 & Governança \\
\hline 3 & Participação Social & 3 & Operação & 3 & Meio Ambiente \\
\hline 4 & Planejamento & 4 & Governança & 4 & Operação \\
\hline 5 & Meio Ambiente & 5 & Participação Social & 5 & Planejamento \\
\hline
\end{tabular}

Para cada uma das avaliações dos PVEs, foram atribuídos valores conforme os atributos qualitativos descritos abaixo:

- FA: Fortemente Aplicado;

- A: Aplicado;

- AM: Aplicação Moderada;

- PA: Pouca Aplicação;

- NA: Nenhuma Aplicação.

Dessa forma, os dados simulados de entrada no programa M-Macbeth constam dispostos na Tabela 5.2. 
Tabela 5.2 - Atribuições de valores para as Cidades 1, 2 e 3.

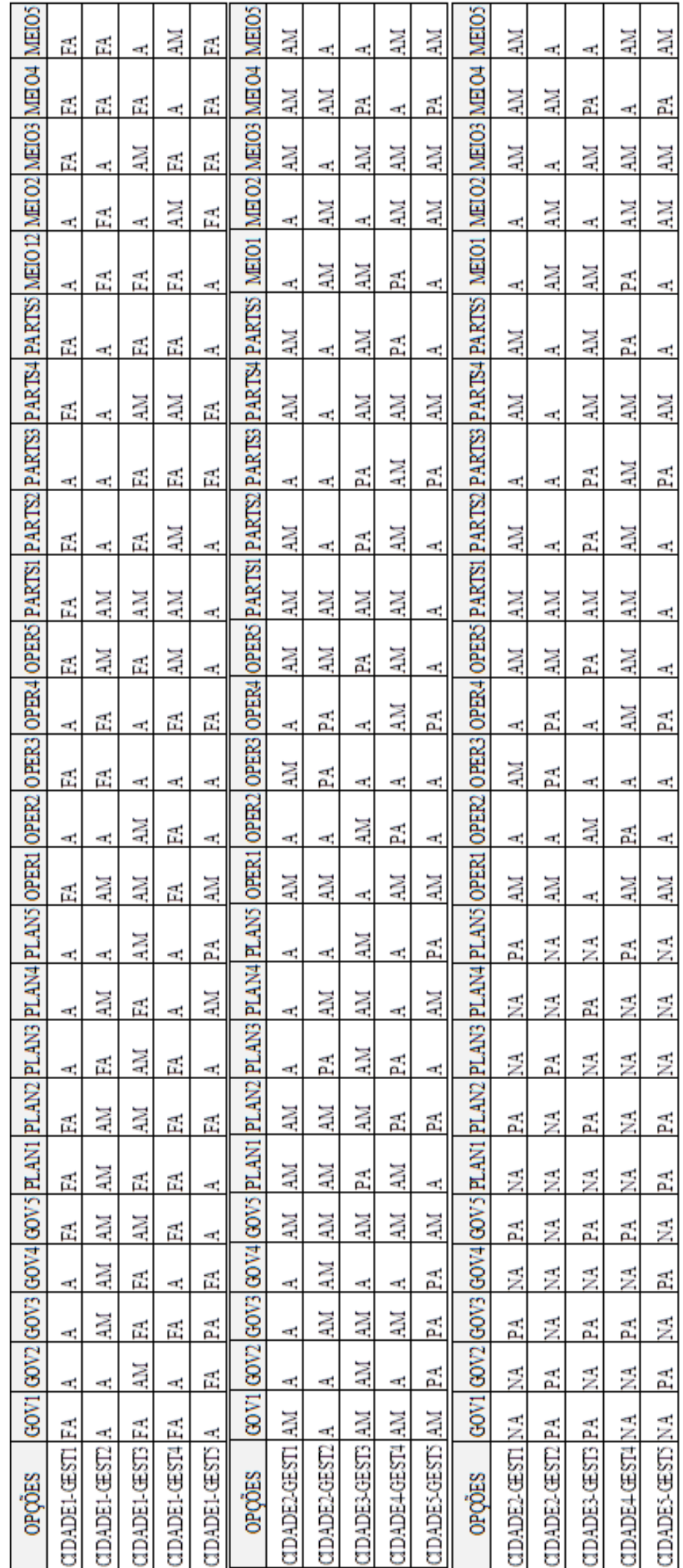




\subsection{RESULTADOS}

O programa realizou simulações das três cidades fictícias, seguindo as ordenações com os valores de atribuições de PVEs descritos anteriormente, obtendo os resultados apresentados a seguir. No Gráfico 5.1, é possível observar que os valores globais de PMU apresentam certa dispersão na visão de cada um dos cinco gestores para a Cidade 1 .

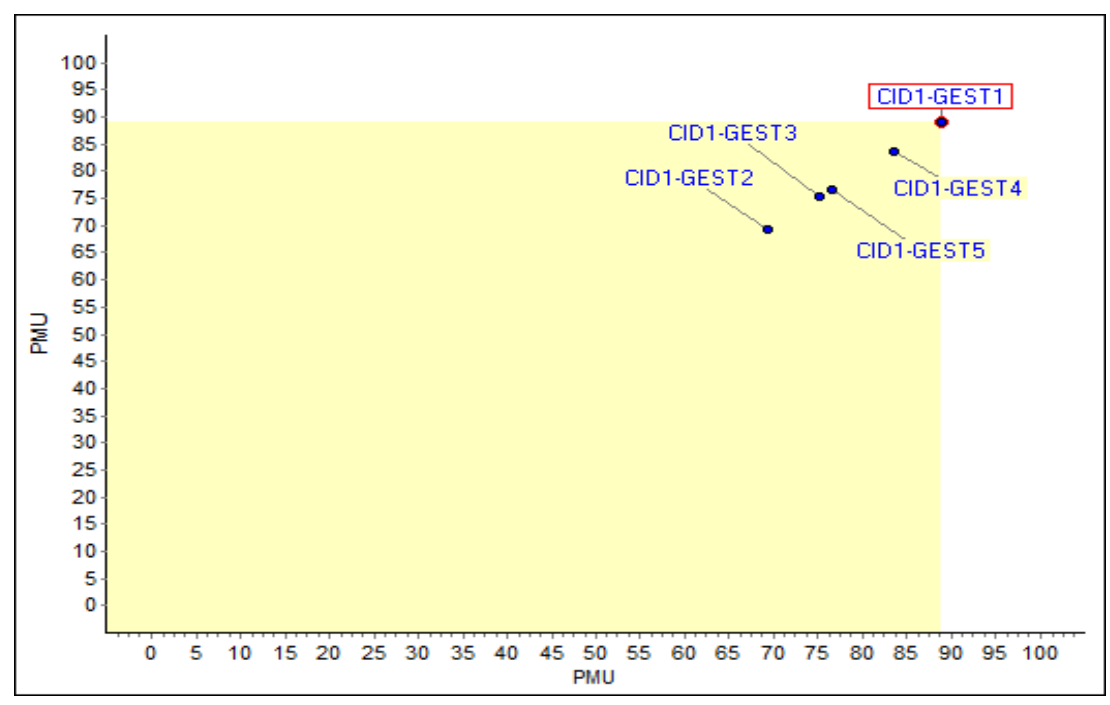

Gráfico 5.1 - Valores de PMU para a Cidade 1

Para explicar o resultado global da avaliação PMU, faz-se necessário observar como ocorrem as distribuições de valores de cada PVF. Nesse sentido, são apresentados nos Gráficos 5.2 a 5.5 os resultados das avaliações dos gestores em cada critério.

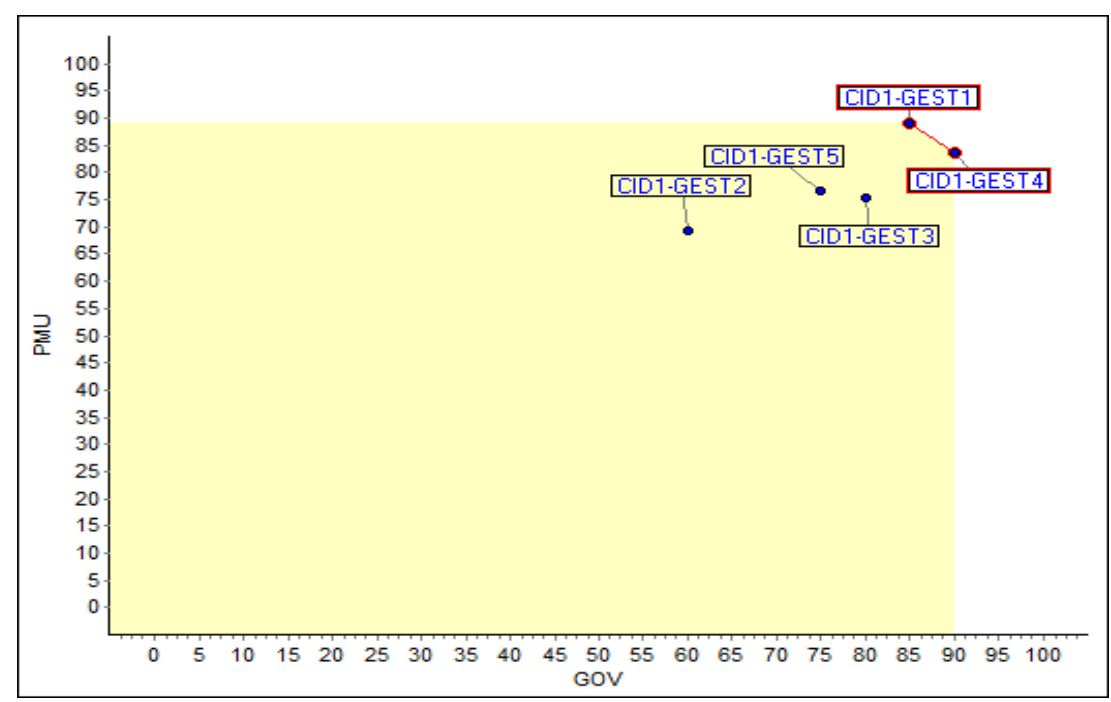

Gráfico 5.2 - Resultados das avaliações do PVF Governança - Cidade 1. 


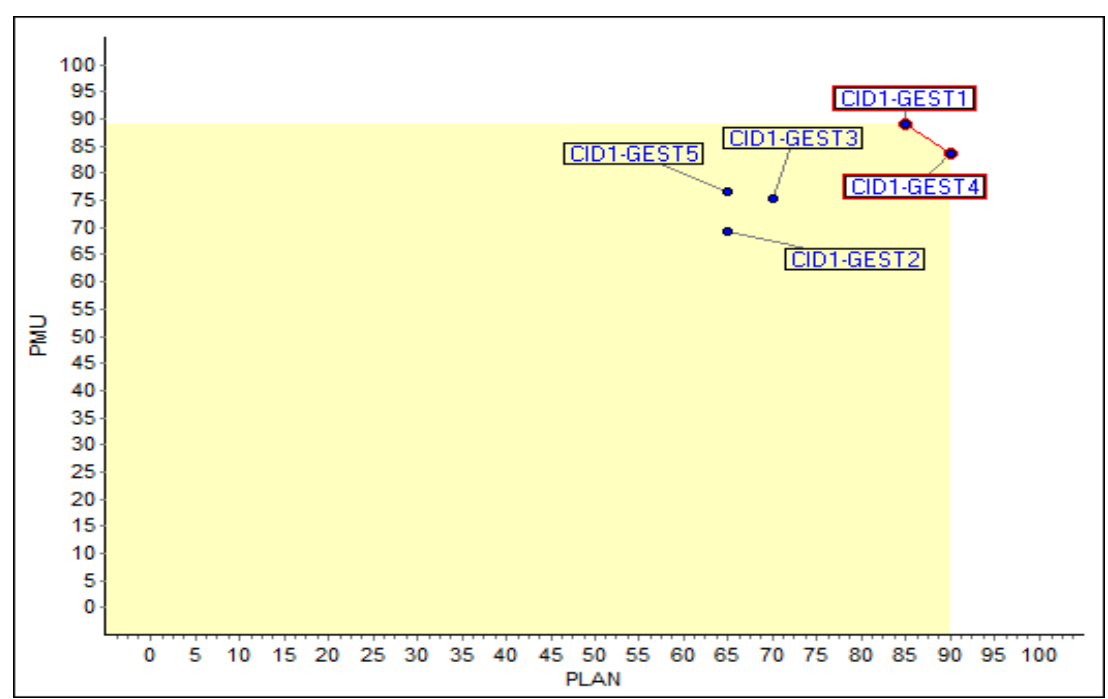

Gráfico 5.3 - Resultados das avaliações do PVF Planejamento - Cidade 1

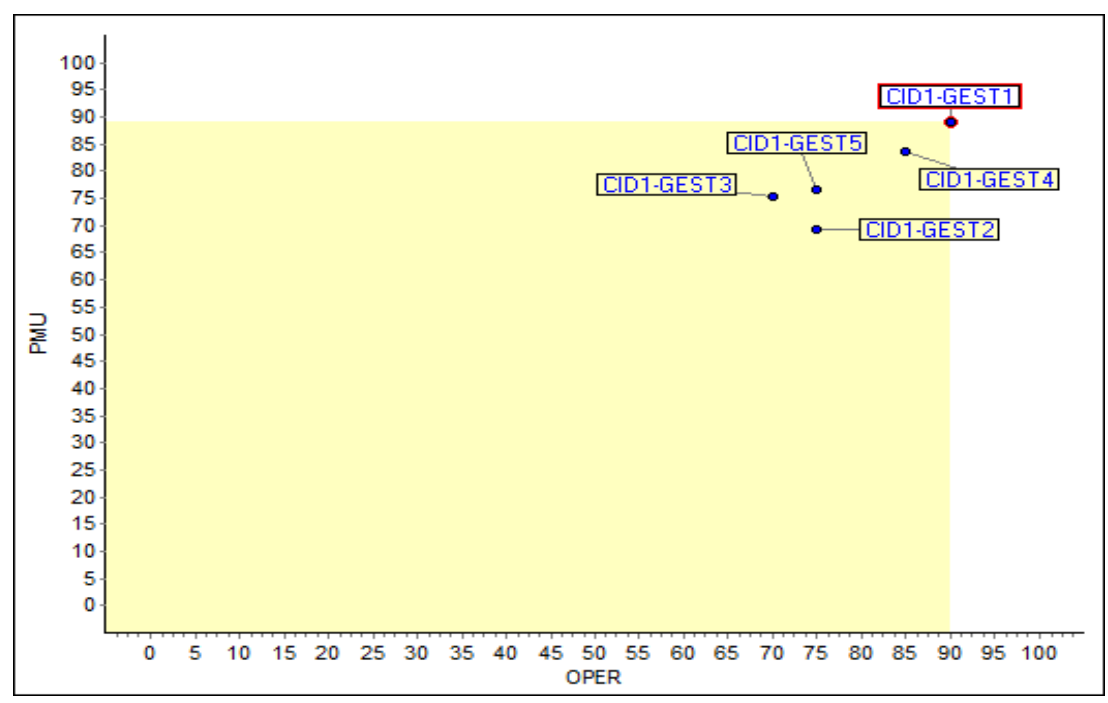

Gráfico 5.4 - Resultados das avaliações do PVF Operações - Cidade 1

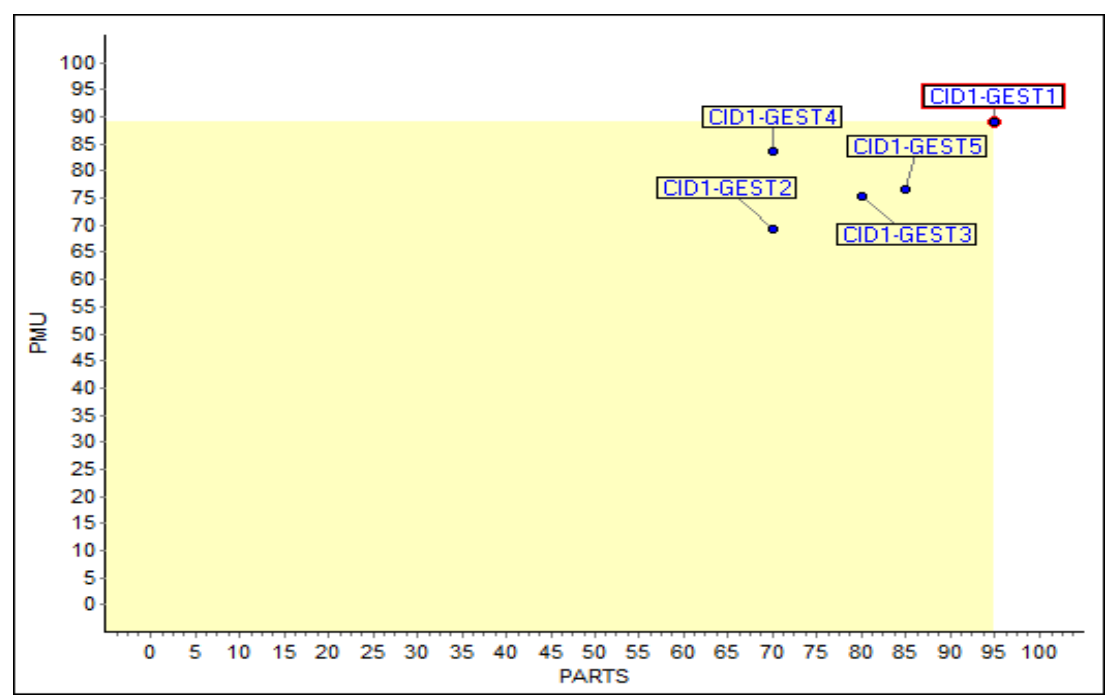

Gráfico 5.5 - Resultados das avaliações do PVF Participação Social - Cidade 1 
Por fim, são apresentados no Graf. 5.6 os resultados das avaliações para o PVF Meio Ambiente.

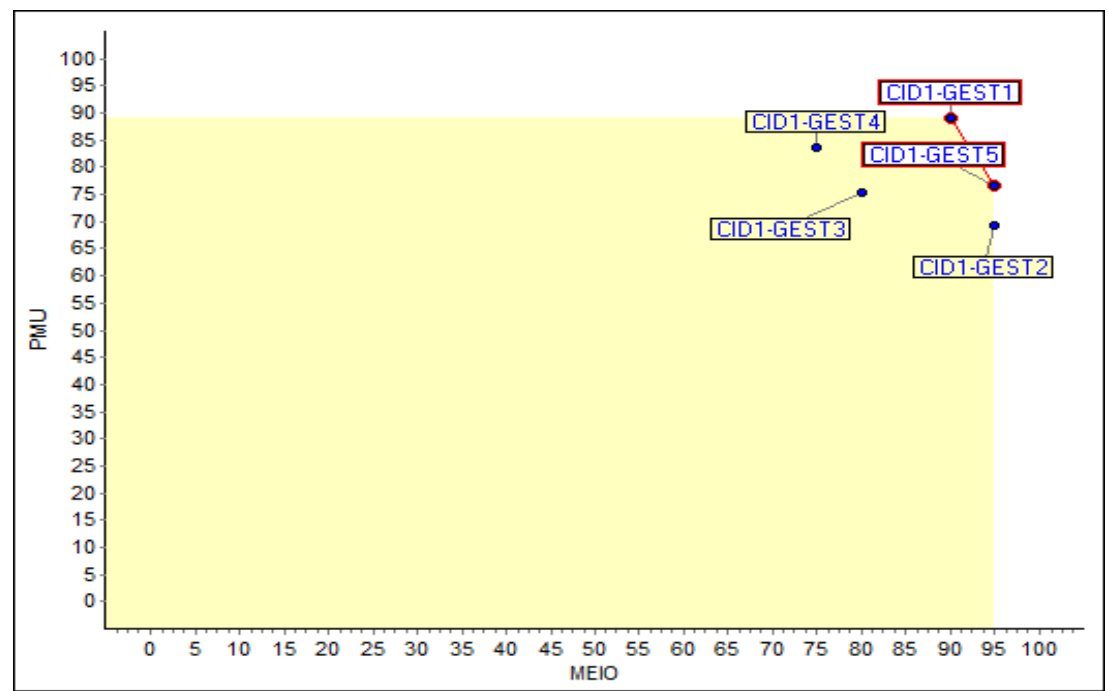

Gráfico 5.6 - Resultados das avaliações do PVF Meio Ambiente - Cidade 1

Para a Cidade 2 (Graf. 5.7), os resultados mostram uma menor variação do valores globais de PMU, o que reflete, em certa medida, uma homogeneidade na percepção dos gestores a respeito da aplicabilidade da política. Porém, os valores estão abaixo dos obtidos nas avaliações da Cidade 1.

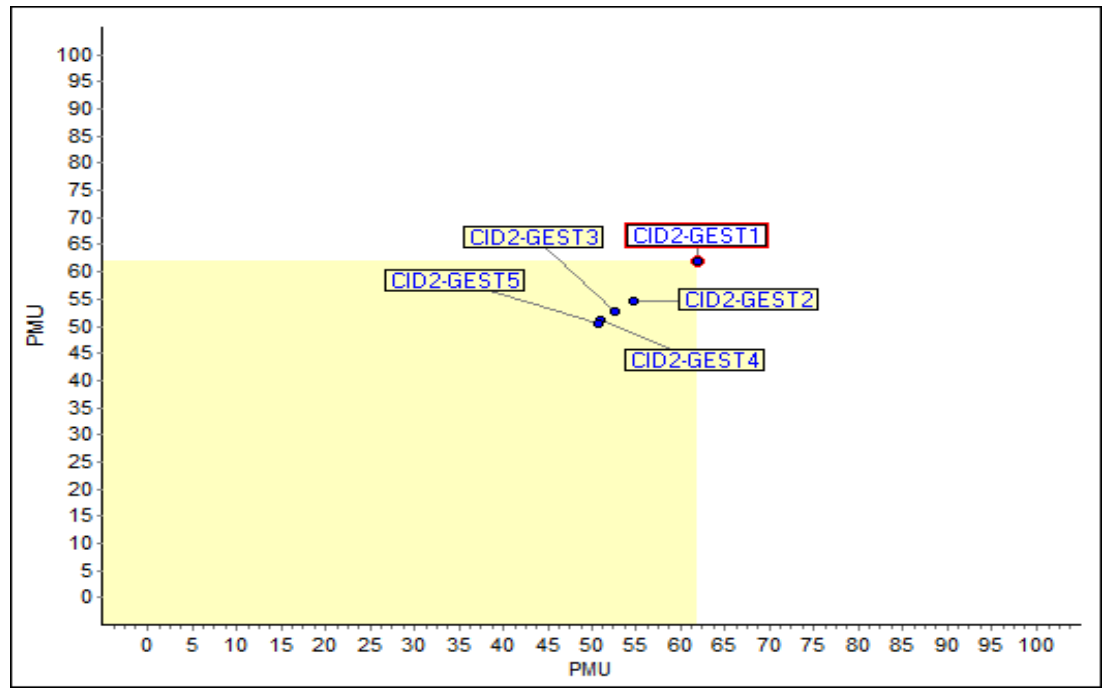

Gráfico 5.7 - Resultados das avaliações PMU para a Cidade 2

De igual maneira, os resultados que explicam os valores globais para a Cidade 2 são apresentados nos Gráficos 5.8 a 5.11. 


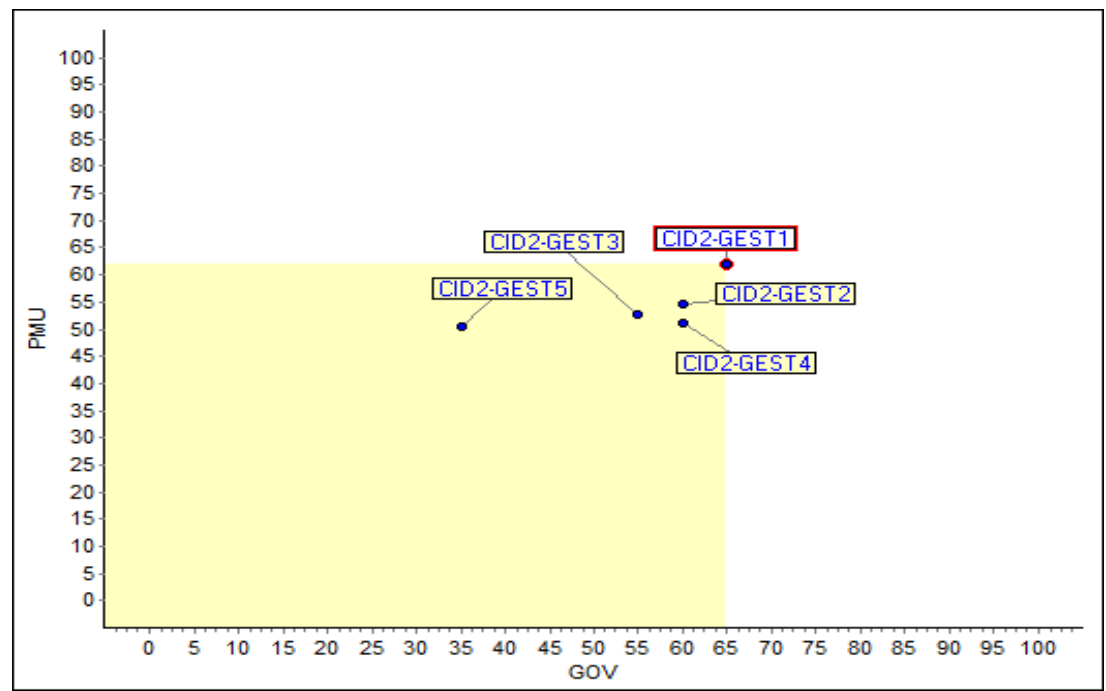

Gráfico 5.8 - Resultados das avaliações do PVF Governança - Cidade 2

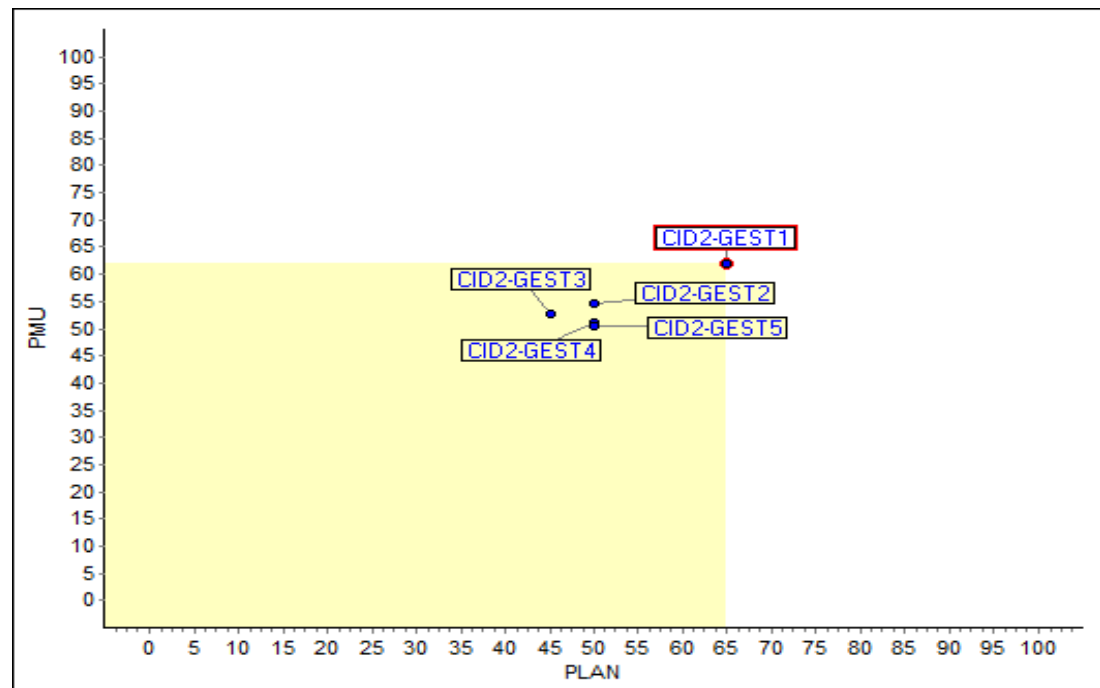

Gráfico 5.9 - Resultados das avaliações do PVF Planejamento - Cidade 2

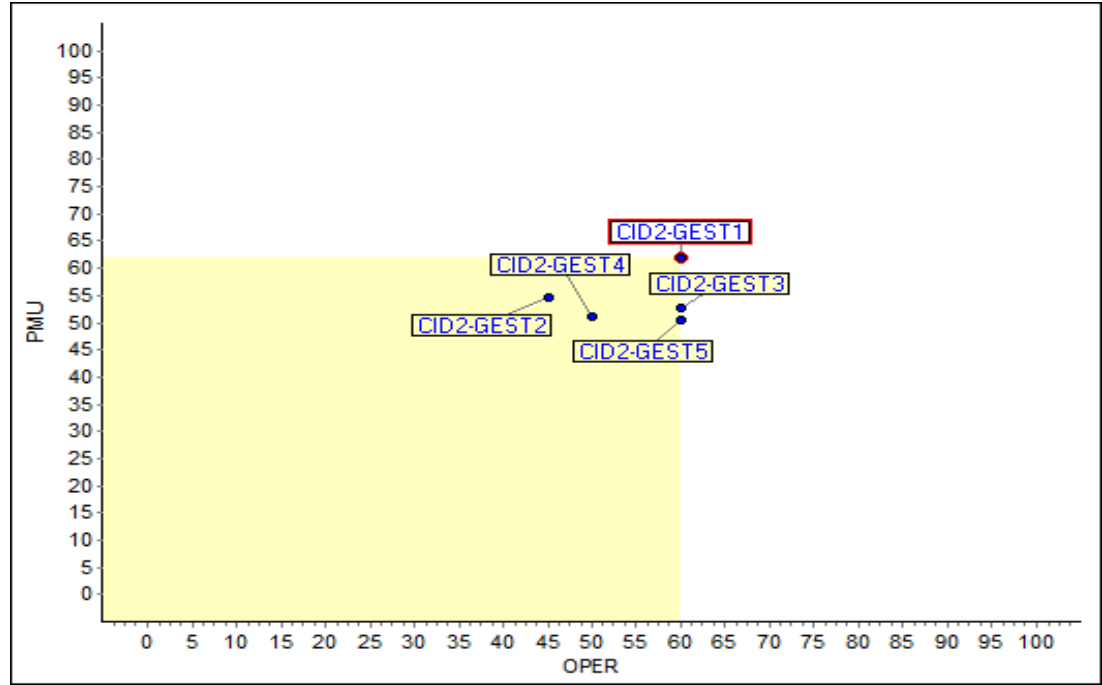

Gráfico 5.10 - Resultados das avaliações do PVF Operações - Cidade 2 


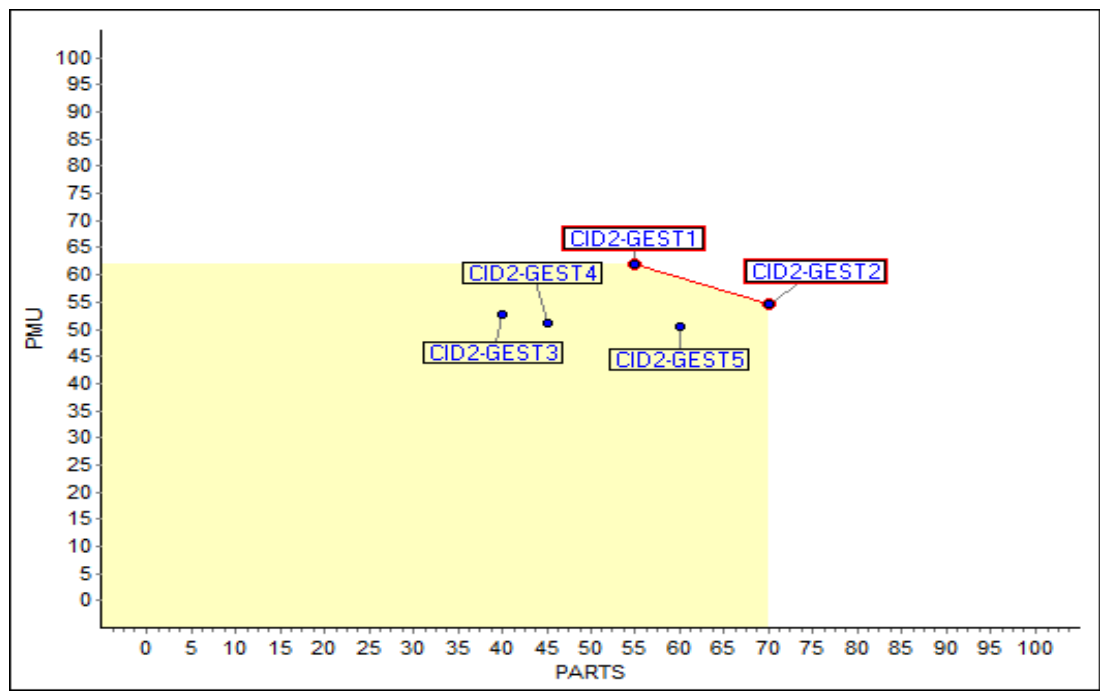

Gráfico 5.11- Resultados das avaliações do PVF Participação Social - Cidade 2

Por último, são apresentados no Graf. 5.12 os resultados das avaliações do PVF Meio Ambiente. As maiores dispersões obtidas nas avaliações da Cidade 2 ocorreram nos critérios Participação Social e Governança.

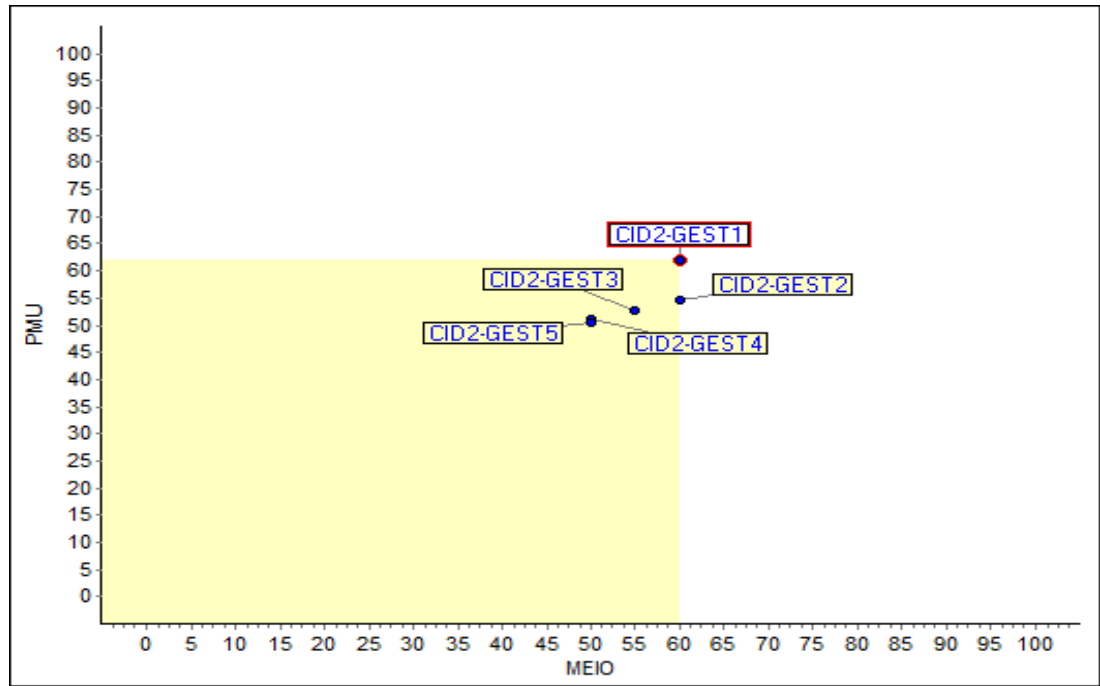

Gráfico 5.12 - Resultados das avaliações do PVF Meio Ambiente - Cidade 2

Finalmente, para a Cidade 3, os valores globais de PMU nas avaliações dos Gestores são apresentados no Graf. 5.13. 


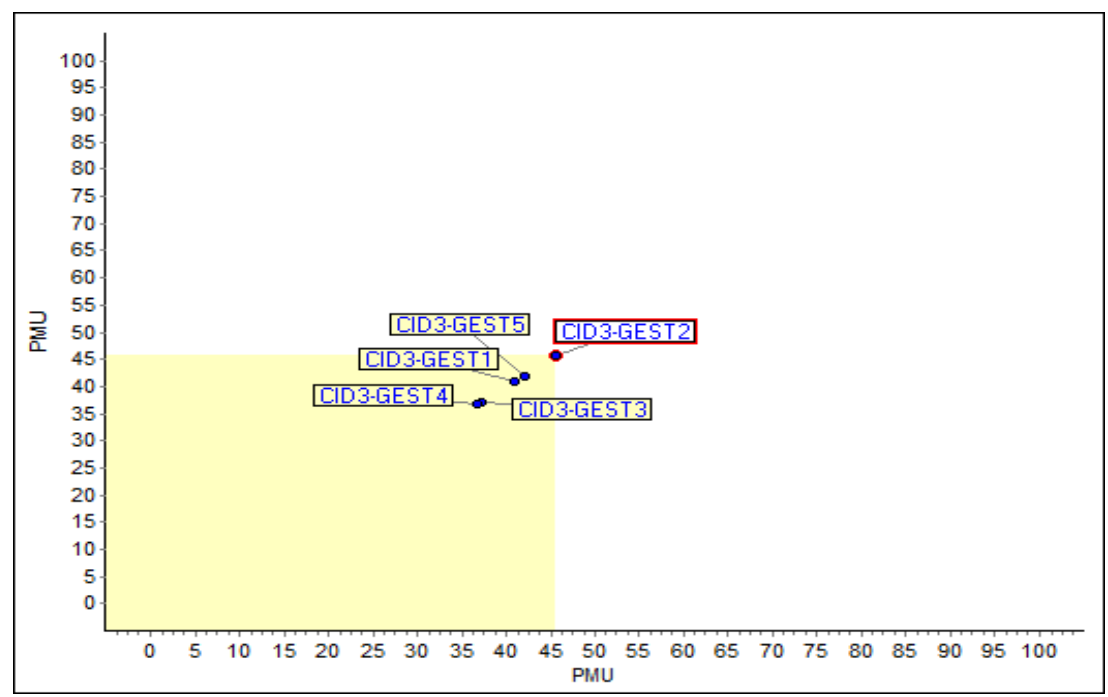

Gráfico 5.13 - Resultados das avaliações PMU para a Cidade 3

As avaliações globais da Cidade 3 foram as mais baixas, fato explicado por valores baixos para os PVEs, conforme apresentados nos gráficos 5.14 e 5.15.

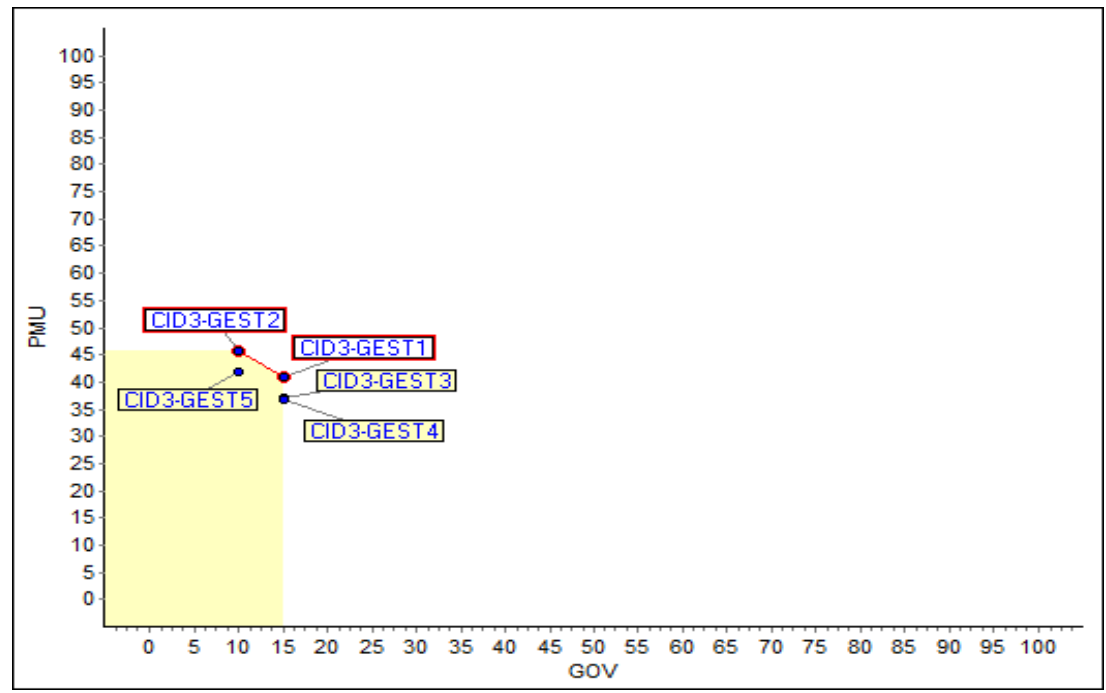

Gráfico 5.14 - Resultados das avaliações do PVF Governança - Cidade 3

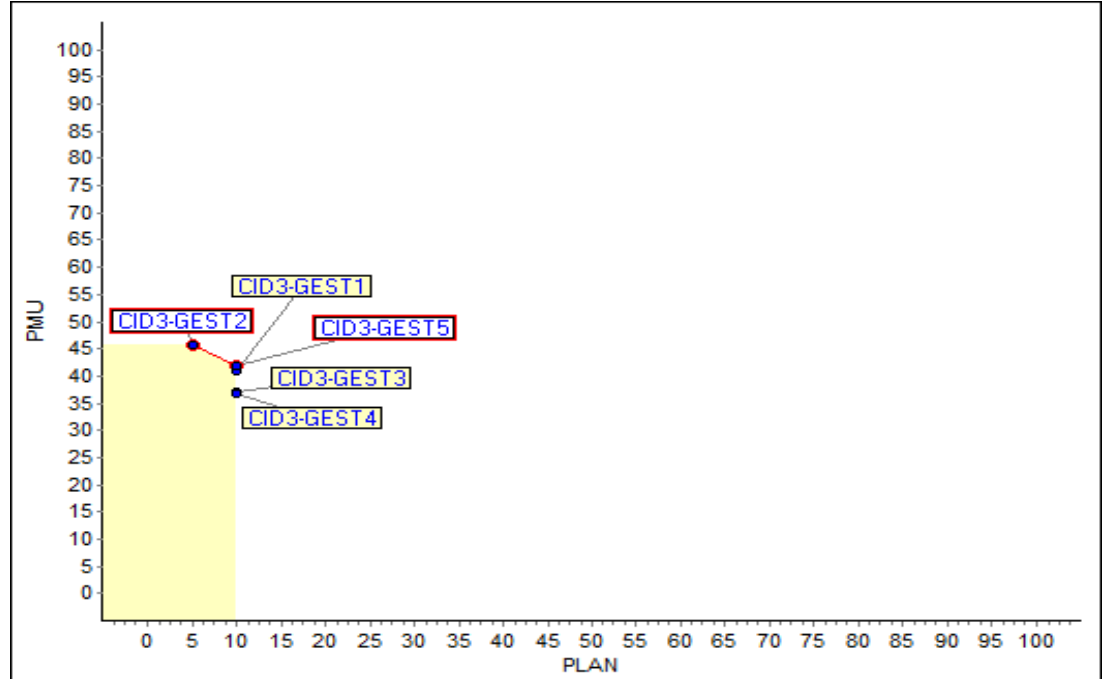

Gráfico 5.15 - Resultados das avaliações do PVF Planejamento - Cidade 3 
Importante observar que os PVEs Governança e Planejamento obtidos são valores baixos e homogêneos. O que pode explicar um alinhamento de percepção dos gestores, e que, com relação a esses dois aspectos da PMU, os municípios não possuem uma aplicabilidade razoável. Nos Gráficos 5.16, 5.17 e 5.18, são apresentados os resultados das avaliações dos PVFs Operações, Participação Social, e Meio Ambiente.

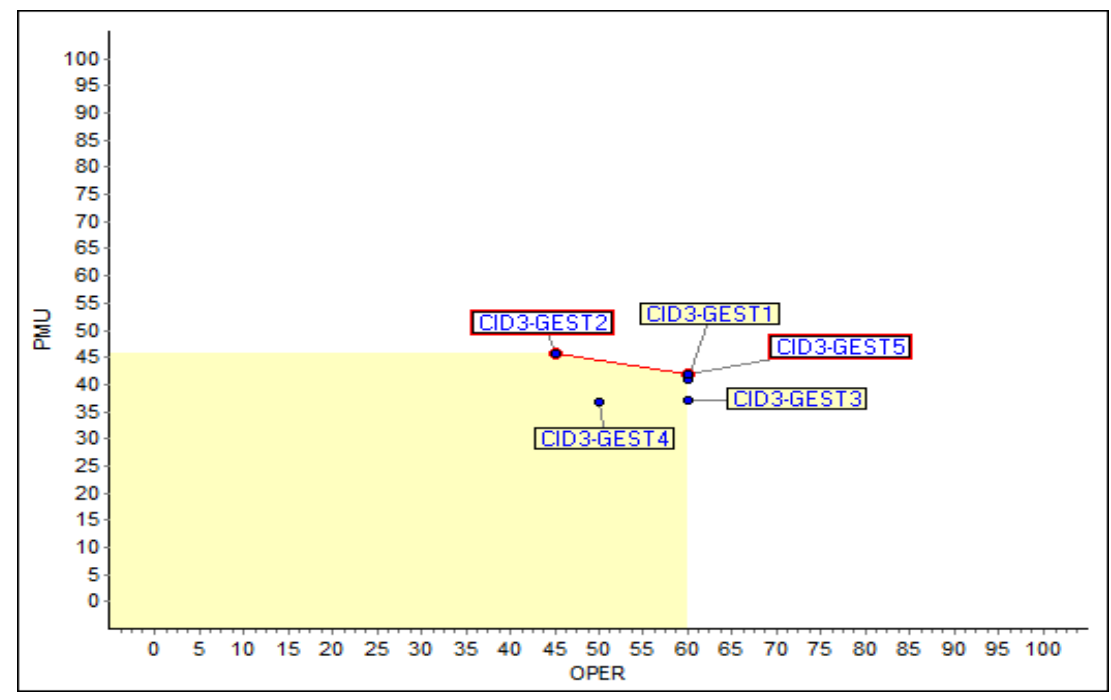

Gráfico 5.16 - Resultados das avaliações do PVF Operações - Cidade 3

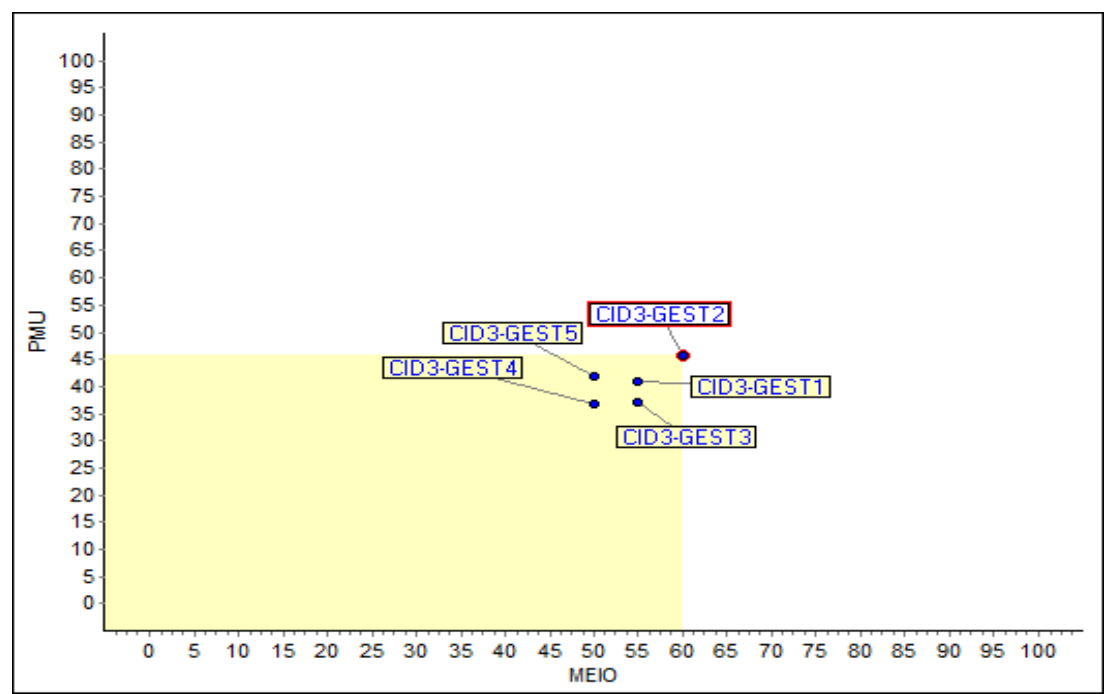

Gráfico 5.17 - Resultados das avaliações do PVF Meio Ambiente - Cidade 3 


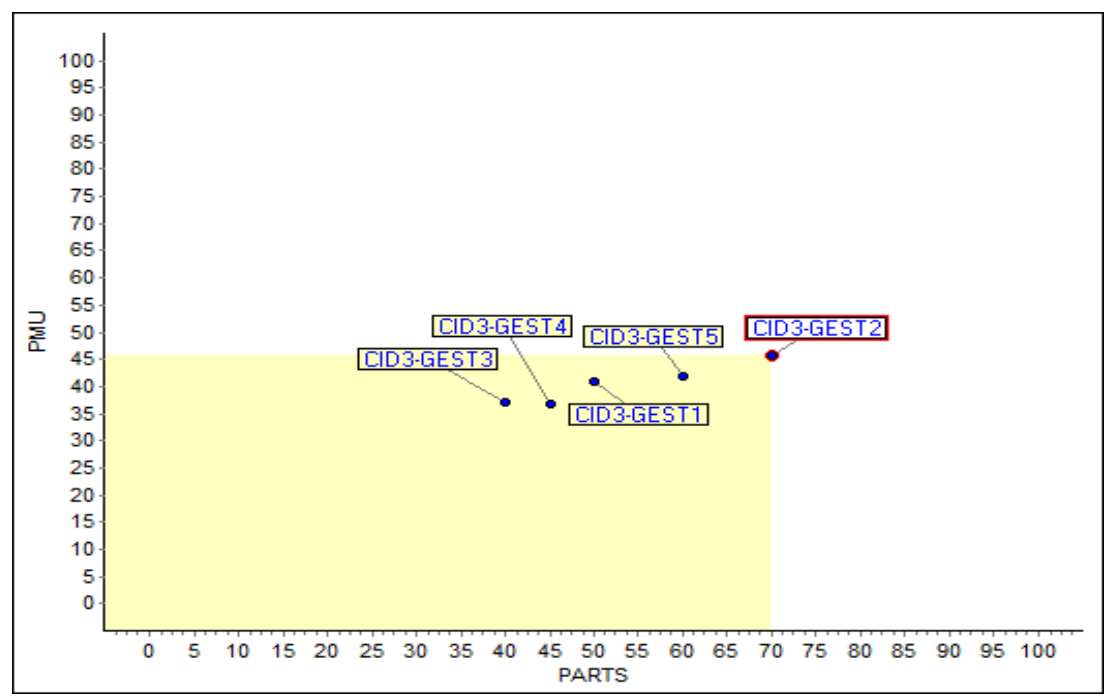

Gráfico 5.18 - Resultados das avaliações do PVF Participação Social - Cidade 3

\subsection{GERAÇÃO DO ÍNDICE DE APLICABILIDADE DA POLÍTICA DE MOBILIDADE URBANA}

O M-Macbeth fornece um comparativo das pontuações globais das três cidades, conforme é apresentado na Tab. 5.3, a essa funcionalidade o programa chama de Termômetro Global. De maneira consolidada os resultados globais das avaliações e os valores parciais de cada PVE são apresentados na Tab. 5.4. 
Tabela 5.3 - Termômetros globais das avaliações PMU para as Cidades 1, 2 e 3 respectivamente.

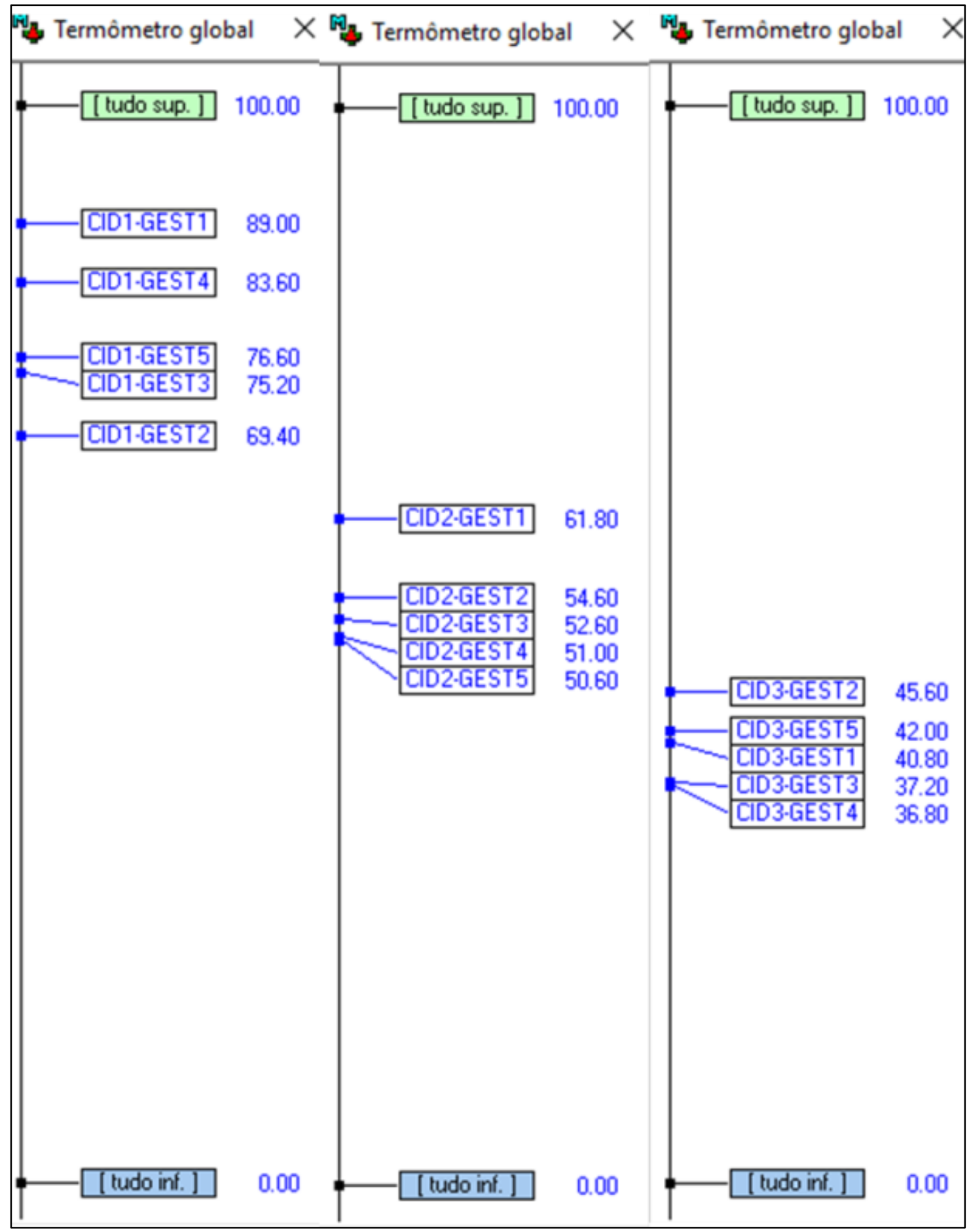


Tabela 5.4 - Pontuações das Cidades 1, 2 e 3.

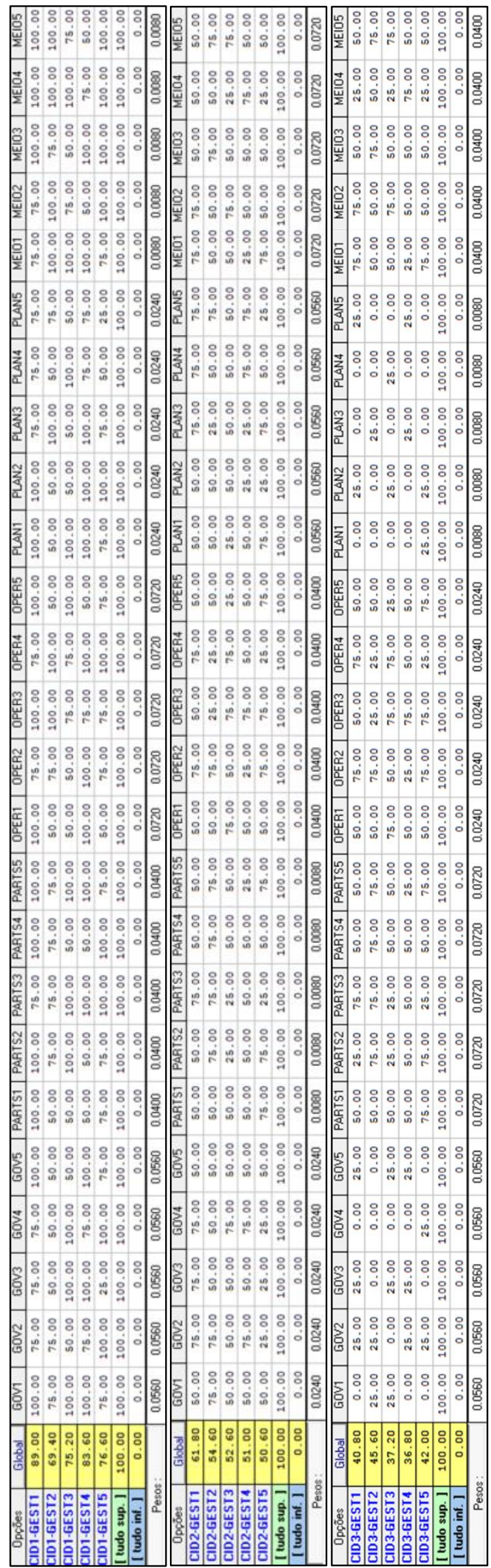


O Índice de Aplicabilidade da Política de Mobilidade Urbana (IPMU) proposto consiste no cálculo da mediana das avaliações de cada uma das cidades. Foi utilizada essa medida de tendência central devido à propriedade desta não ser influenciada por valores extremos. Obtiveram-se, portanto, os seguintes resultados:

- $\quad$ Cidade $1=76,60$;

- $\quad$ Cidade $2=52,60$;

- $\quad$ Cidade $3=40,80$.

A partir da atribuição inicial dos PVEs em cinco graduações, foi elaborada uma faixa aceitável de valores de PMU. Os valores acima de 50 constariam na chamada zona admissível, o que seria primordialmente relativo a valores qualitativos: "Fortemente Aplicado", "Aplicado" e Moderadamente Aplicado, conforme ilustração do Gráfico 5.19.

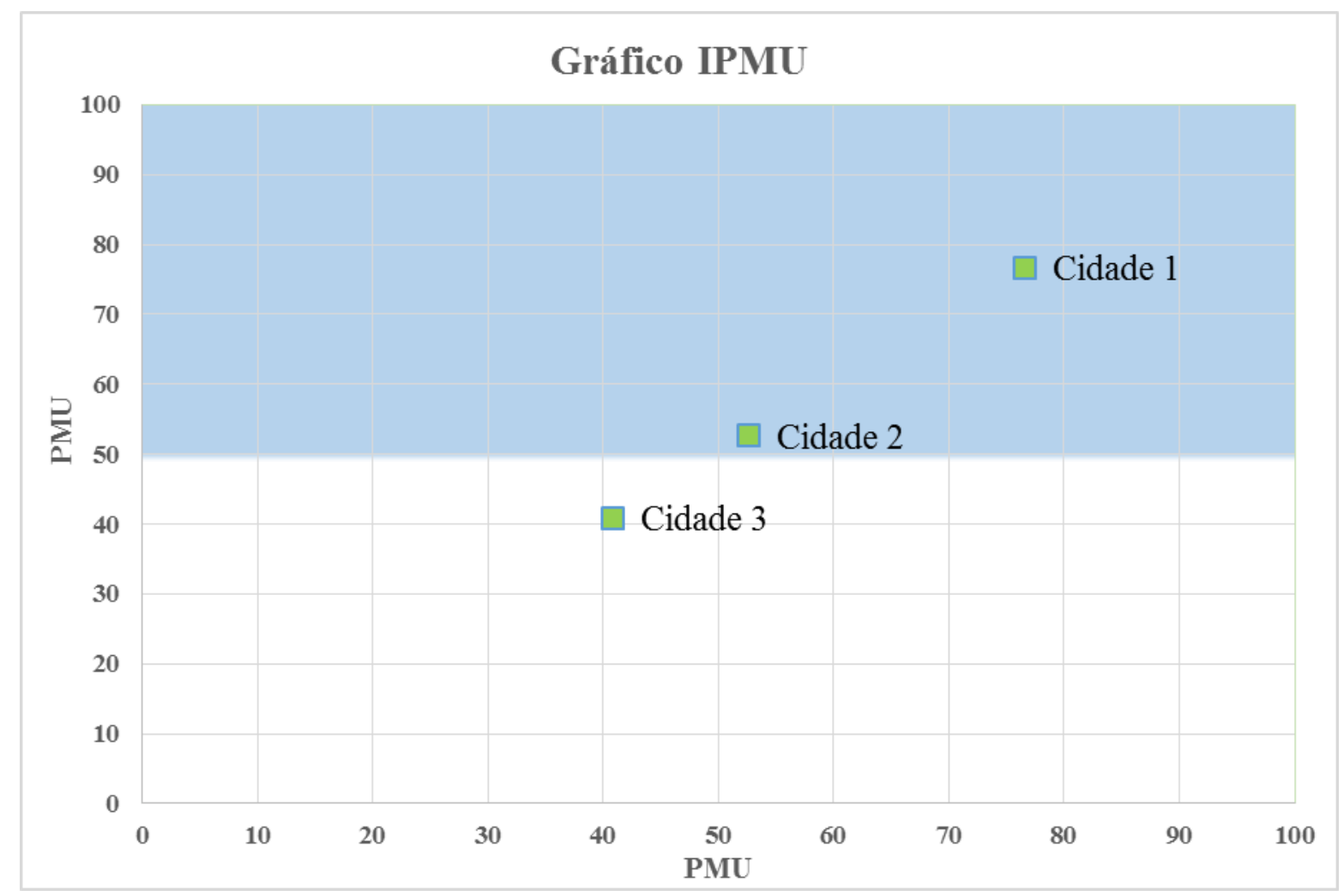

Gráfico 5.19 - Gráfico índice PMU 


\subsection{TÓPICOS CONCLUSIVOS}

A metodologia se aplica em qualquer município que esteja sob a obrigatoriedade de aplicar a Lei 12.587/2012. A conclusão é dada de forma objetiva, por meio da combinação de critérios de avaliação e o M-Macbeth. Todos os fatores subjetivos são traduzidos em uma nota de avaliação, dessa forma, qualquer usuário da metodologia poderá comparar a avaliação final com um patamar mínimo de referência e assim mensurar a efetividade da gestão estratégica, envolvendo decisor e gestores da política de mobilidade urbana do município.

Cabe destacar que os resultados apontados nas simulações reforçam a informação de que poderá haver resultados distintos entre municípios, já que não há como "padronizar vontades e percepções", o que não significa falha do método, apenas a diferença de preferências, haja vista que os critérios se mantêm íntegros no processo. A ferramenta ainda disponibiliza mecanismos para comparar gestores no mesmo bloco de critérios e também de forma global, bem como para estabelecer uma nota de referência a cada executor, permitindo gerar um índice geral para a gestão estratégica de cada município.

A critério do pesquisador, foi definida uma faixa de aceitação ou zona de admissibilidade, para destacar o município com eficiência maior igual a 50,0 na aplicação da PNMU. A Cidade 1 obteve nota de avaliação igual a 76,60, o que a coloca dentro da zona de aceitação ou de admissibilidade, elencada pelo pesquisador. Assim como a Cidade 2 que obteve a nota 52,60. Já a Cidade 3 com a nota 40,80 ficou fora da zona de admissibilidade. Destarte, as Cidades 1 e 2, na ótica da metodologia, possuíram gestão estratégica aderente aos princípios, diretrizes e objetivos da Lei de Mobilidade. 


\section{VALIDAÇÃO DA FERRAMENTA - APLICAÇÃO EM ESTUDO DE CASO.}

Neste capítulo, será apresentado o estudo caso em que foi aplicado a ferramenta multicritério proposta. Neste sentido, inicialmente serão abordadas as características locais e os dados de entrada. Ao final, serão apresentados e discutidos os resultados obtidos das avaliações no programa M-Macbeth.

Cabe destacar que neste capitulo participa a figura do pesquisador, como facilitador do processo de validação. Também participam o decisor, como responsável pela estratégia do órgão de mobilidade do Município. Por fim, participam os responsáveis pela execução da PMU no Município de Palmas (denominados de gestores). A participação dos três elementos fica evidente ao longo da aplicação da ferramenta em caso concreto.

\subsection{CARACTERÍSTICAS LOCAIS}

A cidade objeto do estudo de caso foi Palmas, capital do estado do Tocantins. Encravada na região central do Brasil, Palmas possui população, segundo estimativa do IBGE de 2016, de cerca de 280 mil habitantes.

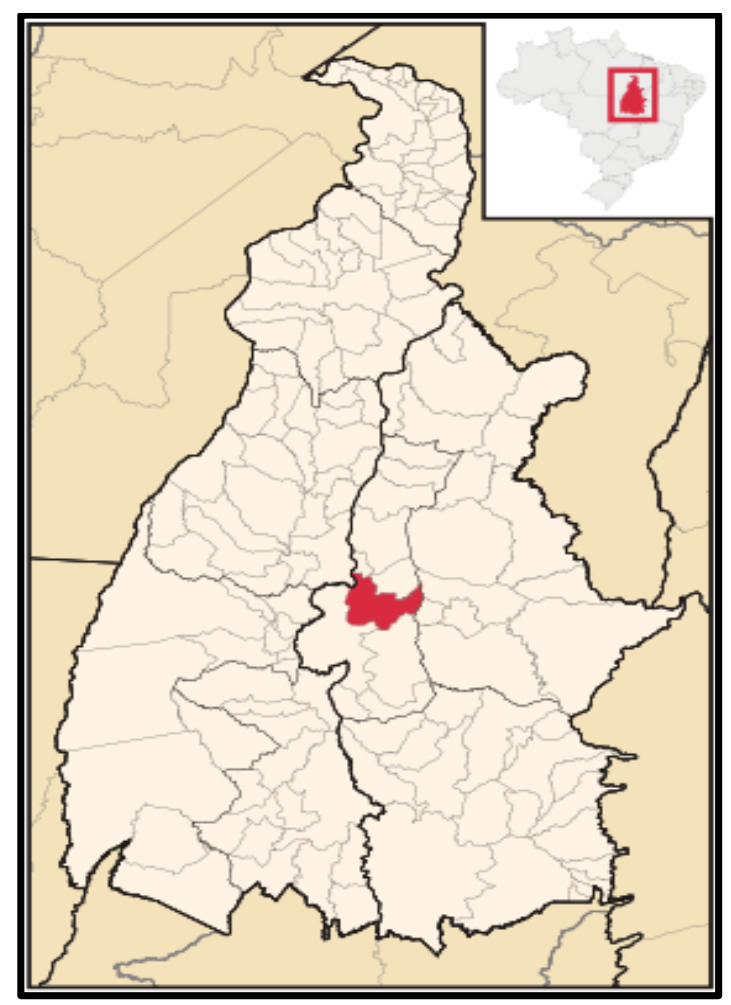

Figura 6.1- Estado do Tocantins com o Município de Palmas em destaque. 
Palmas, a última cidade planejada do século XX, tornou-se capital definitiva do Estado do Tocantins em $1^{\circ}$ de janeiro de 1990 . O nome da cidade é uma homenagem à Comarca de São João da Palma, de onde surgiu o primeiro movimento separatista em 1809, na barra do rio Palma com o rio Paranã. A cidade de Palmas, com apenas vinte e sete anos de existência, "nasceu" no dia 20 de maio de 1989, após a criação do Estado do Tocantins pela Constituição de 1988. Segundo Silva (2010), caracteriza-se como uma cidade planejada que vertiginosamente "apareceu" no meio do cerrado, no final do séc. XX. Um ano depois virou a capital do Estado do Tocantins, quando passou a ter estrutura mínima para abrigar a sede administrativa do governo do Estado.

A cidade é tangenciada à oeste pelo importante Rio Tocantins, que nasce no Planalto Central e corta o Estado no sentido Sul-Norte, conforme demonstra a Fig. 6.2 destacando a área urbana da capital. Além disso, os Municípios adjacentes a Palmas são: Lajeado e Aparecida do Rio Negro localizados ao norte da capital; Novo Acordo e Santa Tereza do Tocantins localizados a leste; Monte do Carmo localizada a sudeste; Porto Nacional ao sul; além do Município de Miracema do Tocantins localizado a noroeste da cidade de Palmas.

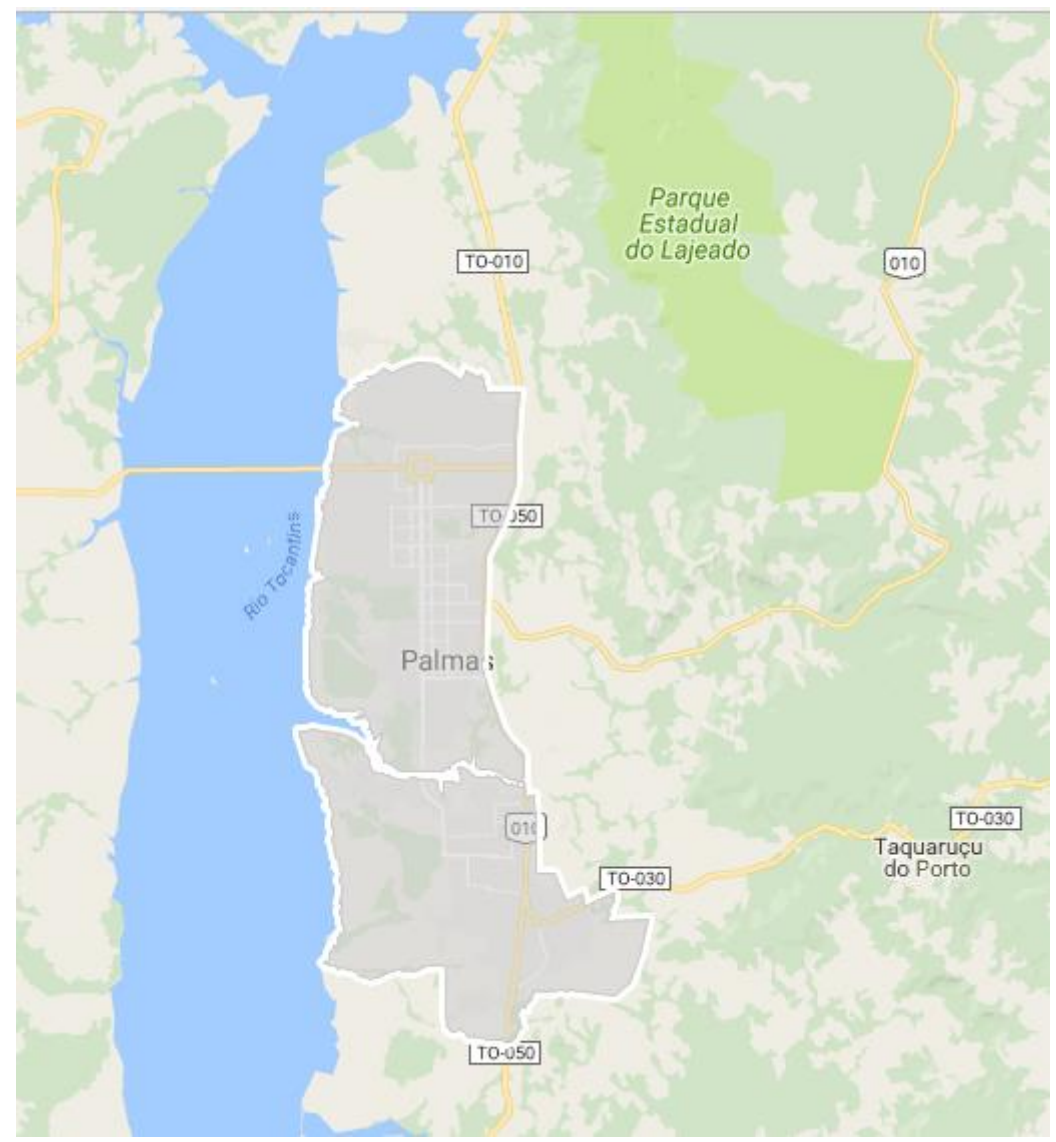

Figura 6.2 - Área Urbana de Palmas - Divisão de Georreferenciamento/Sec. de Desenv. Urbano Sustentável/Prefeitura de Palmas-TO (2016). 
O Município possui algumas rodovias que atravessam sua circunscrição, tais como: BR-010, TO-010, TO-020, TO-030, TO-040, TO-050, TO-070, TO-080, TO-365 e TO-453, conforme mostra a Fig. 6.3. Atualmente três empresas operam no sistema de transporte coletivo, possuindo a cidade seis terminais de integração e uma secretaria específica que atua na área de transportes: a Secretaria Municipal de Acessibilidade, Mobilidade, Trânsito e Transporte.

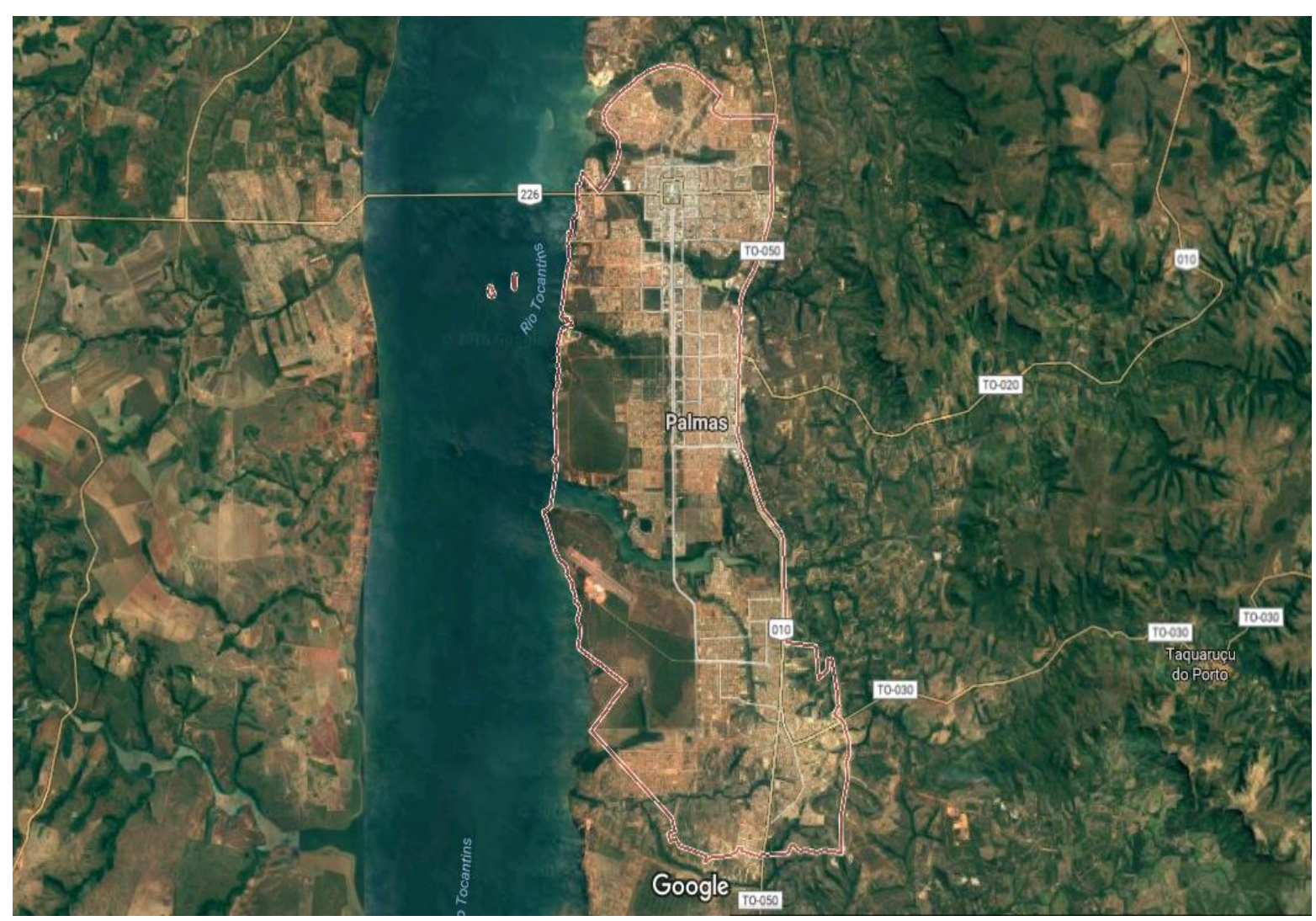

Figura 6.3- Vista aérea do Município de Palmas e rodovias (Google-2016).

A cidade é conhecida pelo seu nível de planejamento, estruturado a partir do cruzamento de duas importantes avenidas: a avenida J.K. no sentido leste/oeste e a avenida Teotônio Segurado no sentido norte/sul. Cabe destacar que "a capital foi desenhada com um traçado viário hierarquizado ditado por uma macromalha em tabuleiro de xadrez que facilita o fluxo de veículos através de suas amplas avenidas, estabelecendo a estrutura principal para deslocamentos de longa distância e distribuição de veículos por toda a cidade" (KNEIB, 2014, p.171).

A Fig. 6.4 evidencia o traço planejado da capital, com suas quadras organizadas em regiões norte, sul, leste e oeste, assentadas em planície, formam a área do Plano Diretor. O centro político-administrativo do Estado está localizado na região central da cidade. No "ponto de 
confluência" das avenidas JK e Teotônio Segurado encontra-se a Praça dos Girassóis e o Palácio Araguaia, sendo a praça um importante marco cultural da cidade, onde figuram monumentos da história do Estado do Tocantins. A leste da praça está localizado a Serra do Carmo e do Lajeado e a oeste a Ponte Fernando Henrique Cardoso, com seus $8.000 \mathrm{~m}$ de cumprimento, que liga Palmas a rodovia BR 153.

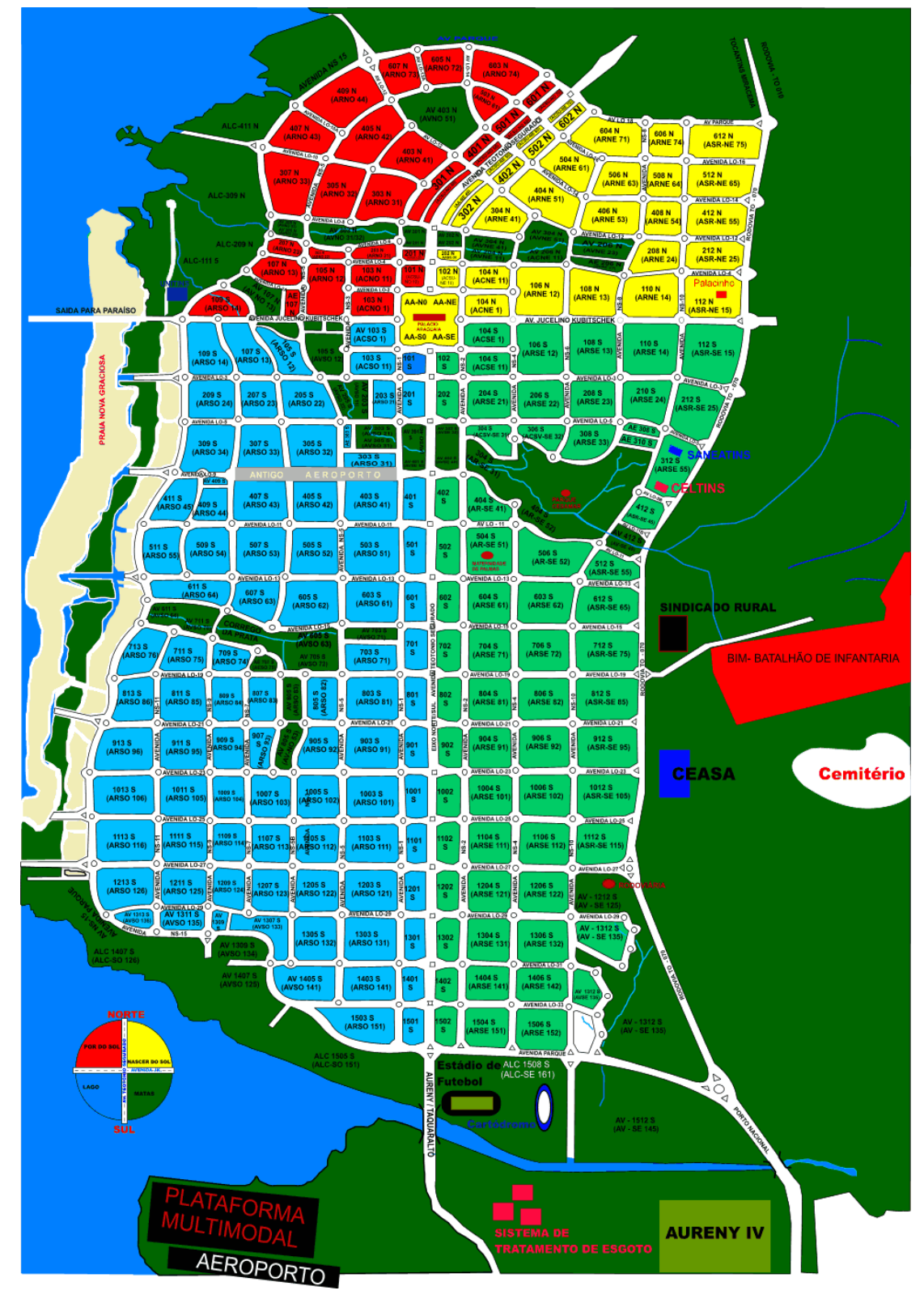

Figura 6.4 - Plano Diretor (2015)

A cidade passou por um crescimento visivelmente acelerado nos últimos anos, e mesmo não tendo carregado grandes problemas históricos, como outras capitais do Brasil, ainda assim apresenta desafios importantes no campo da mobilidade urbana, tais como: priorização do transporte público coletivo, promoção de modos de transporte não motorizado, integração do 
tema mobilidade com as demais políticas de desenvolvimento urbano e a construção de agendas positivas para promover o desenvolvimento sustentável à luz da PNMU.

A capital também tem conflitos derivados do seu zoneamento urbano, principalmente situado na região sul da cidade. De acordo com Kneib (2014, p.174) "surgiu um aglomerado urbano de baixa renda na região sul que não fazia parte do projeto original, resultando em realidades totalmente distintas: um dentro, e outro fora do plano". O preço do lote no plano diretor da cidade, intensificou o povoamento de áreas como o distrito de Taquaralto e bairros Aurenys. A Fig. 6.5 evidencia o ordenamento de Palmas destacando a região sul.

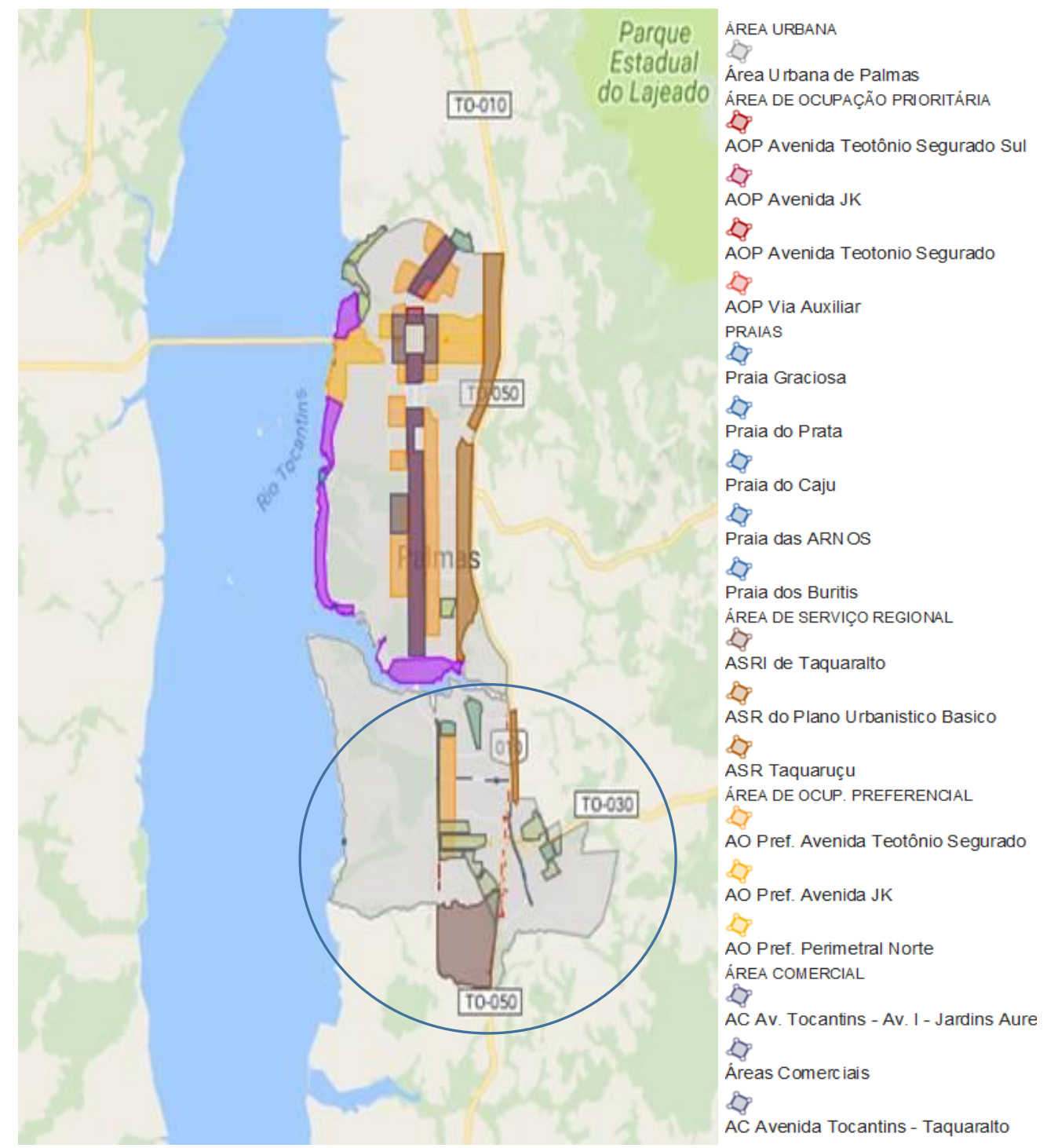

Figura 6.5 - Ordenamento de Palmas - Divisão de Georreferenciamento/Sec. de Desenv. Urbano Sustentável/Prefeitura de Palmas-TO (2016). 
Para Kneib (2014, p.174) "o contraste social entre as duas regiões tem gerado movimentos pendulares diários, fazendo com que a população menos favorecida (fora do plano) se desloque por ônibus ou bicicleta para a região central (dentro do plano), onde existe uma maior oferta de empregos, serviços e infraestrutura". A Fig. 6.6 evidencia a imagem das duas áreas citadas.

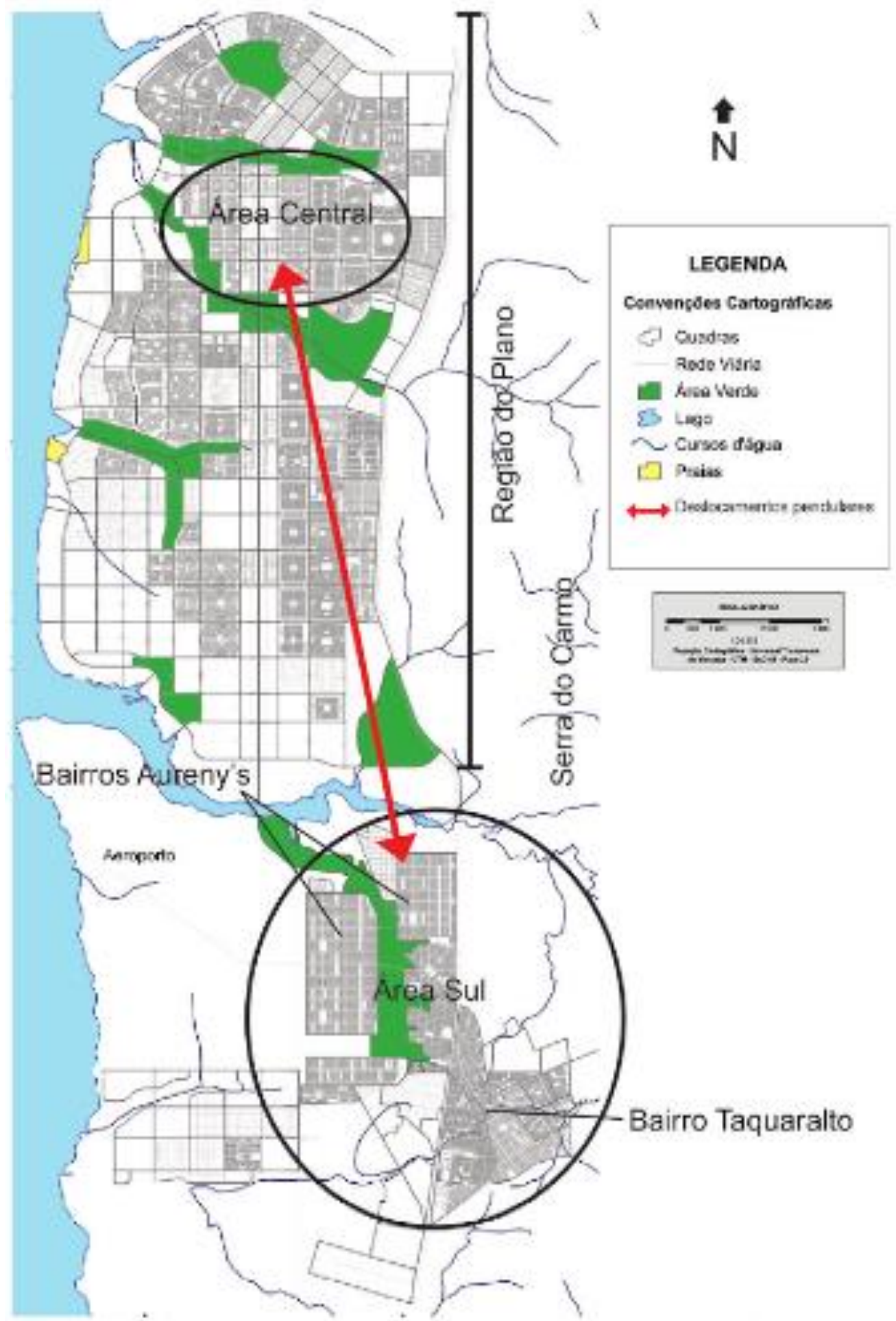

Figura 6.6 - Deslocamento Pendular da área sul para a área central da cidade (kneib, 2014). 
Atualmente o Município de Palmas está em processo de revisão do seu Plano Diretor, cuja primeira ATA de Audiência Pública data de 08 de junho de 2016, abrindo ao público o planejamento do processo de revisão. O Município possui Conselho de Acessibilidade, Mobilidade e Transporte (CMAMT) atuante, formado por vários segmentos da sociedade, como setores governamentais e não-governamentais.

O Sistema viário do Município de Palmas se caracteriza a partir das vias estruturais definidas pelo Plano Diretor, as quais determinam sua hierarquia. Fazem parte do sistema viário principal as seguintes vias Estruturais: Avenida Teotônio Segurado (Eixo Norte-Sul), a Avenida JK (Eixo Leste-Oeste). O sistema viário Secundário é formado por vias Coletoras e Locais que separam, em sua maioria, quadras geometricamente retangulares.

A frota de veículos tem apresentado grande crescimento nos últimos anos. O IBGE estima que de 2001 a 2012 houve um crescimento de 240\%. Os dados da frota municipal de veículos em 2015 são apresentados na Tabela 6.1, conforme levantamento do Departamento Nacional de Trânsito (Denatran) em 2015.

Tabela 6.1 - Frota de veículos do município de Palmas-TO. (Fonte: IBGE 2015)

\begin{tabular}{|l|r|}
\hline & \multicolumn{1}{|c|}{ Frota -2015} \\
\hline Automóvel & 60.532 automóveis \\
\hline Caminhão & 4.888 caminhões \\
\hline Caminhão trator & 644 caminhões trator \\
\hline Caminhonete & 15.192 caminhonetes \\
\hline Camioneta & 4.171 camionetas \\
\hline Micro-Ônibus & 327 micro-ônibus \\
Motocicleta & 43.456 motocicletas \\
Motoneta & 16.197 motonetas \\
\hline Ônibus & 1.832 ônibus \\
\hline $\begin{array}{l}\text { Trabor de Rodas } \\
\text { Utilitário } \\
\text { Outros }\end{array}$ & 13 tratores de rodas \\
\hline
\end{tabular}




\subsection{DADOS DE ENTRADA}

Seguindo a metodologia apresentada nos capítulos anteriores, foram feitas avaliações com o decisor, responsável pela pasta da mobilidade na Secretaria Municipal de Acessibilidade, Mobilidade, Trânsito e Transporte, e com gestores vinculados a essa secretaria, conforme apresentado na Fig. 6.7.

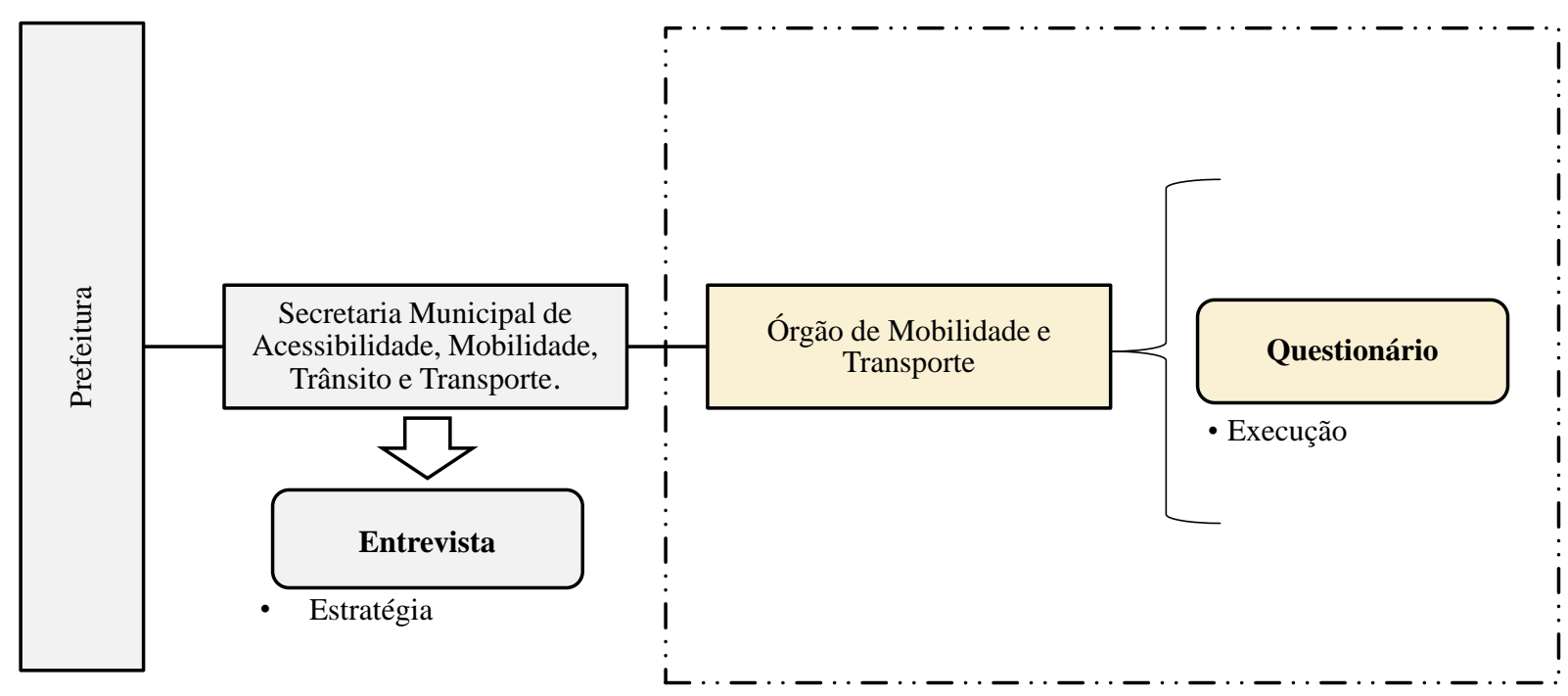

Figura 6.7 - Secretaria Municipal de Acessibilidade, Mobilidade, Trânsito e Transporte - Palmas-TO

Os valores das ordenações e os resultados das atribuições do decisor, captados pela entrevista na matriz de preferência, são apresentados na Tabelas 6.2.

Tabela 6.2 - Ordenação das preferências do decisor

\begin{tabular}{|c|l|}
\hline \multicolumn{2}{|c|}{ PALMAS-TO } \\
\hline ORDEM & \multicolumn{1}{c|}{ PVF } \\
\hline 1 & Participação Social \\
\hline 2 & Planejamento \\
\hline 3 & Meio Ambiente \\
\hline 4 & Governança \\
\hline 5 & Operação \\
\hline
\end{tabular}

Os resultados do questionário são apresentados na Tabela 6.3, no formato do M-Macbeth, contendo os Critérios de Avaliação vinculados por gestor. Nessa fase, destaca-se a importância de alimentar (dados de entrada) o software do programa com as escolhas em cada bloco de respostas. Além disso na Fig. 6.8 pode ser visto a matriz de julgamentos do decisor. 
Tabela 6.3 - Avaliações dos Gestores

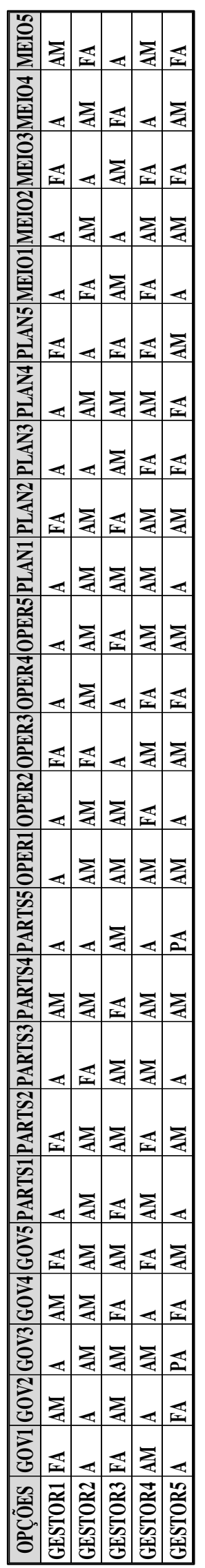




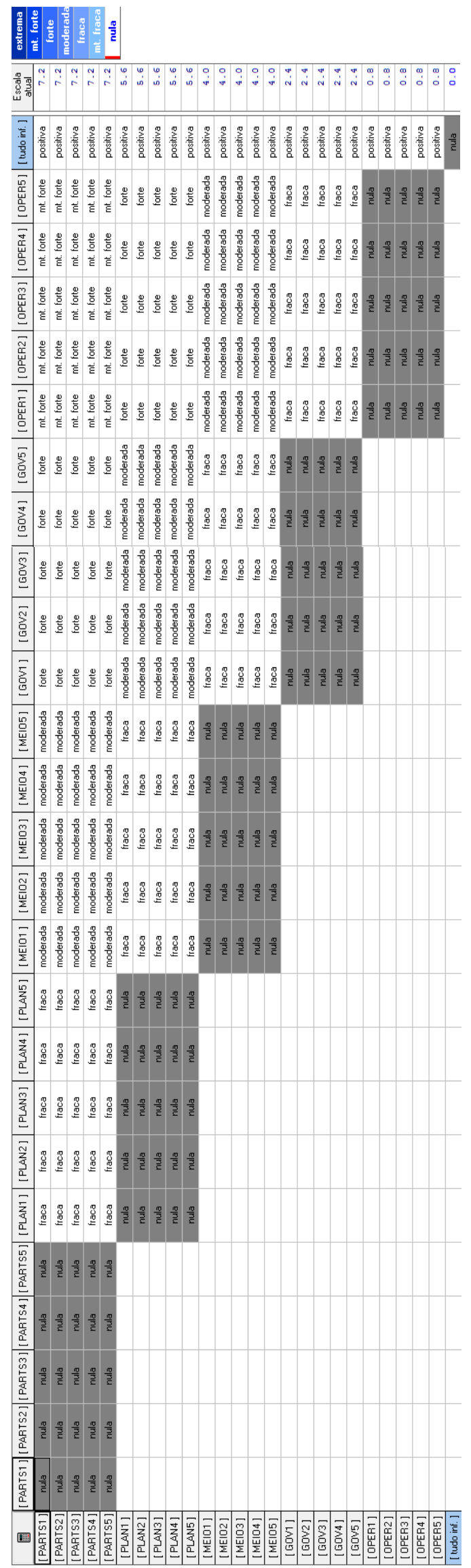

Figura 6.8 - Matriz de julgamentos do decisor 


\subsection{RESULTADOS}

As avaliações foram inseridas no programa M-Macbeth, no modelo proposto no Capítulo 4. Os resultados obtidos para cada PVF são apresentados nos Gráficos 6.1 a 6.5.

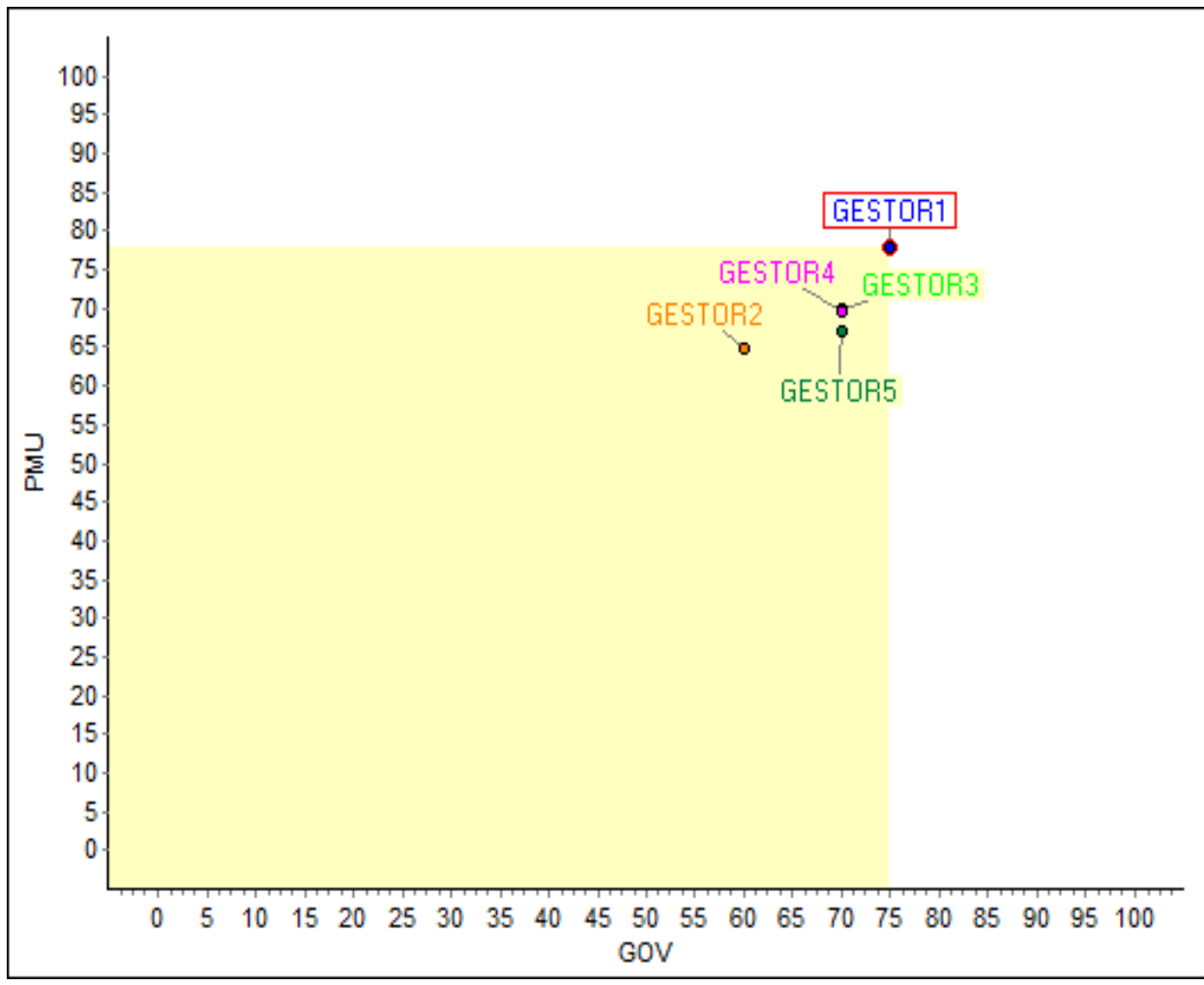

Gráfico 6.1 - Avaliações dos gestores no PVF Governança.

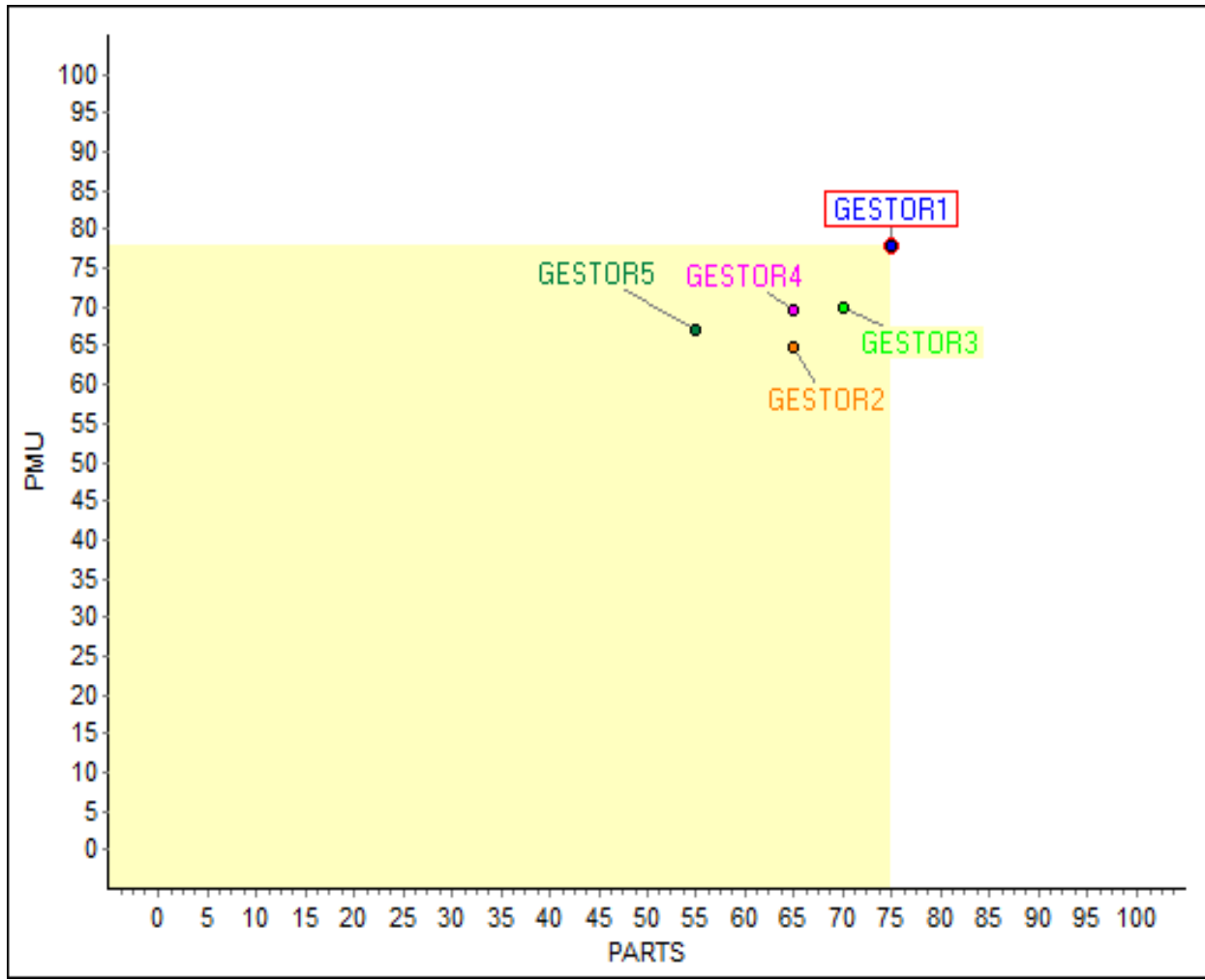

Gráfico 6.2 - Avaliações dos gestores no PVF Participação Social. 


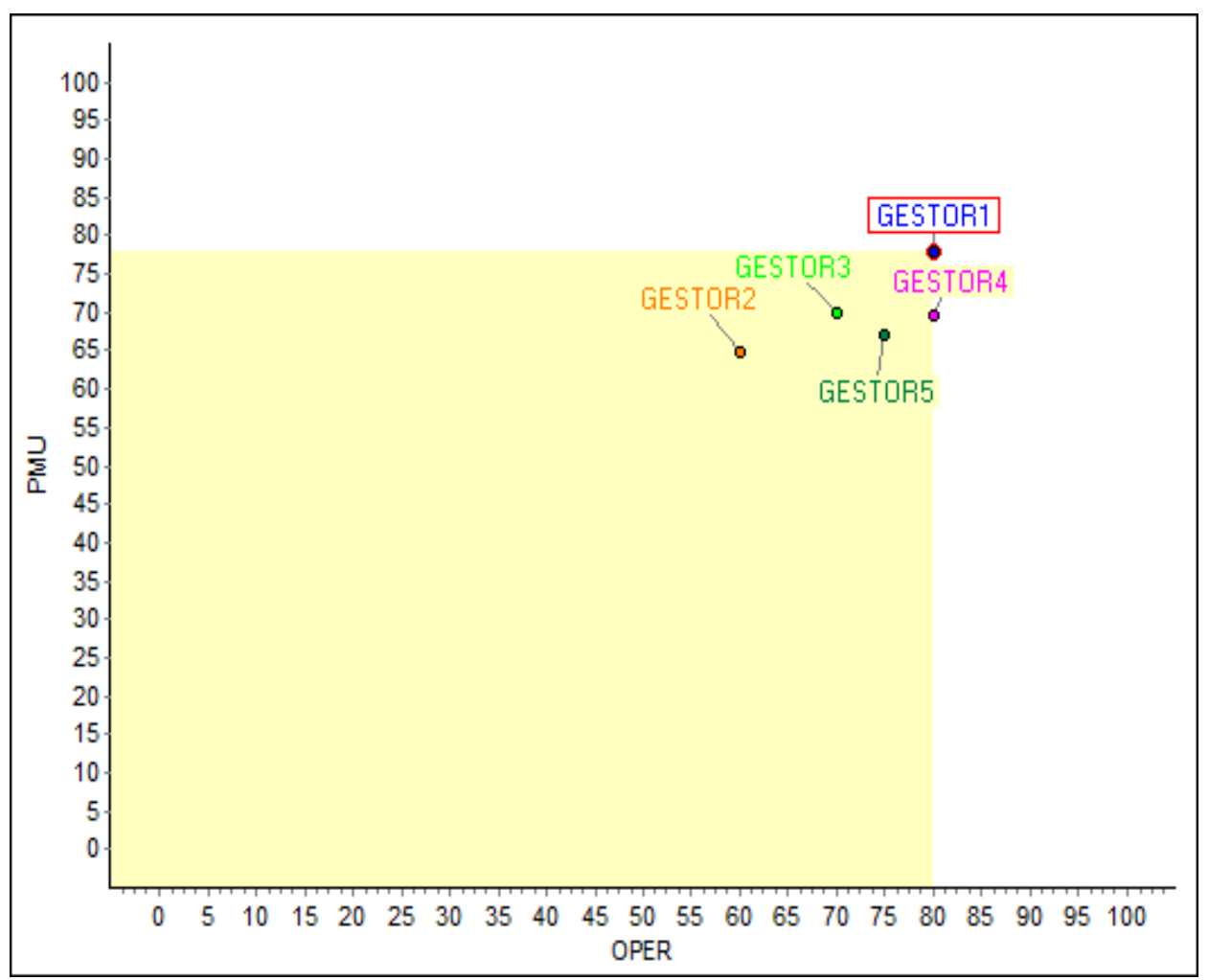

Gráfico 6.3 - Avaliações dos gestores no PVF Operações.

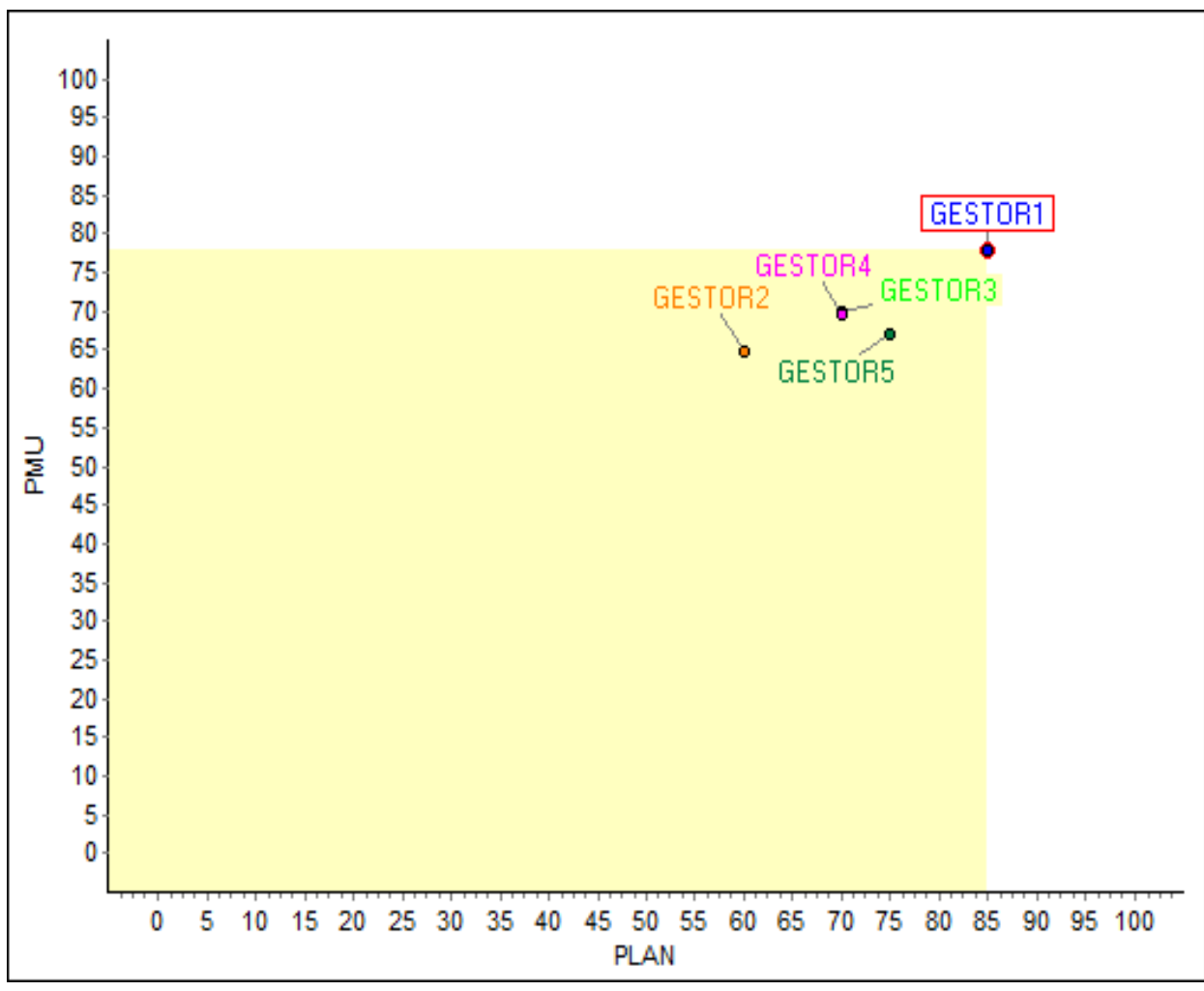

Gráfico 6.4 - Avaliações dos gestores no PVF Planejamento. 


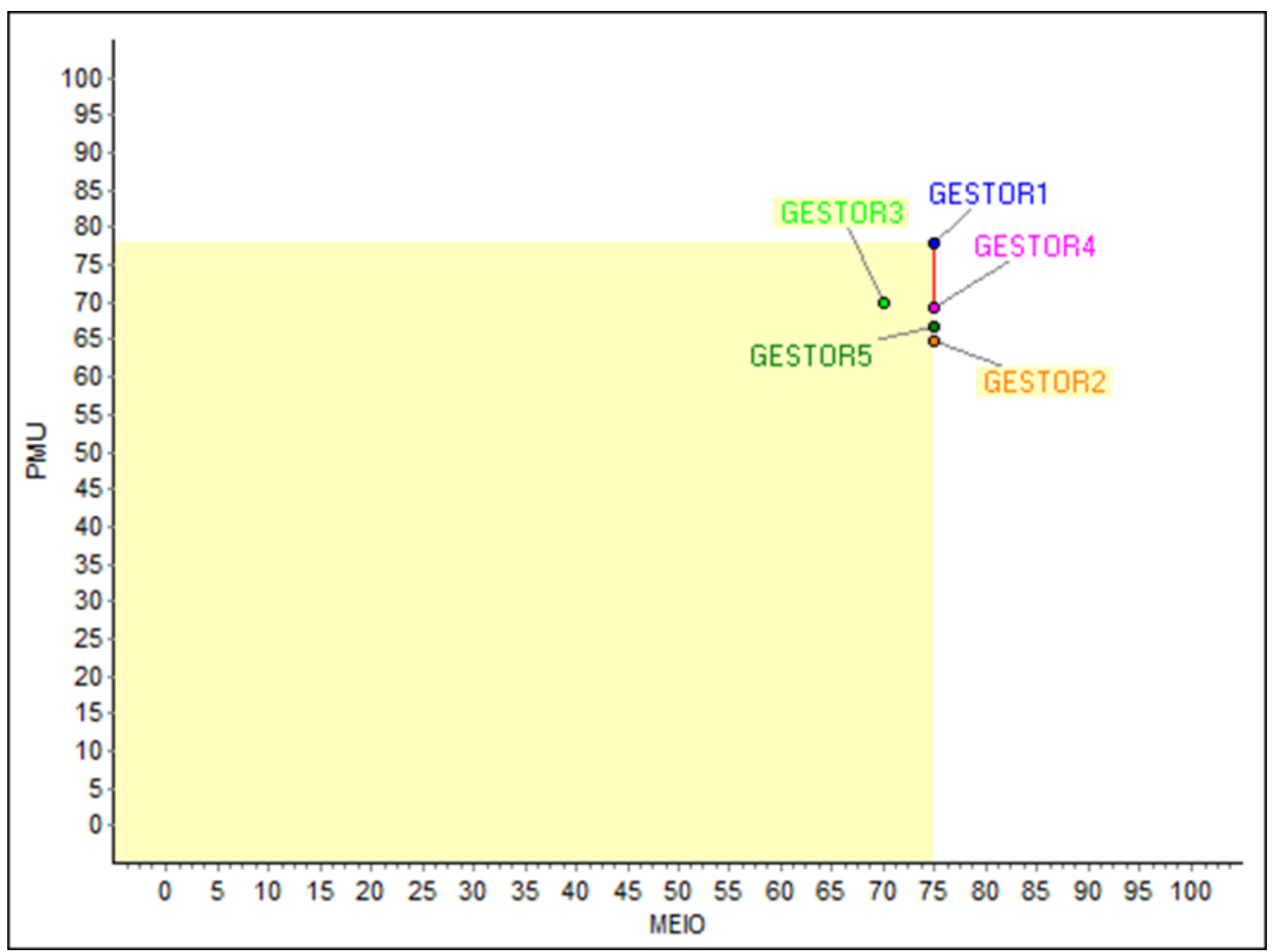

Gráfico 6.5 - Avaliações dos gestores no PVF Meio Ambeiente.

As avaliações de cada gestor perfazem, assim como nas simulações do Capítulo 5, um índice global. Este, por sua vez, é constituído do arranjo das avaliações sobre a aplicabilidade da Política de Mobilidade Urbana de cada PVF. Como forma de apresentar o processo de formação deste índice, o programa fornece o perfil de cada gestor, em que é mostrada a participação de cada atributo dos PVEs avaliados. Os perfis de avaliações dos cinco gestores são apresentados nos Gráficos 6.6 a 6.10 .

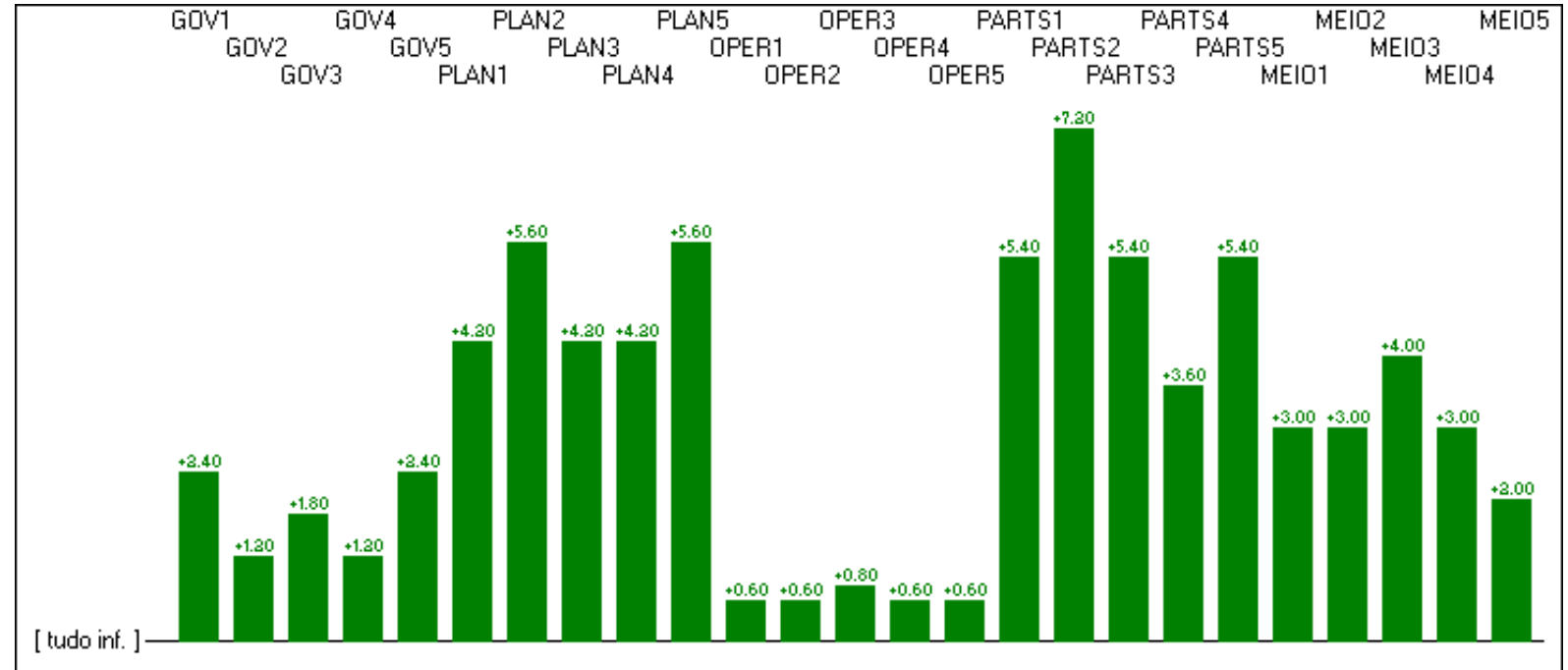

Gráfico 6.6 - Perfil de avaliações do Gestor 1 
Conforme o Graf. 6.6, que exibe o perfil de avaliações do gestor 1, os atributos que obtiveram avaliações de maior aplicabilidade foram Participação Social e Planejamento. Os PVEs de menor execução ficaram contidos no PVF Operação.

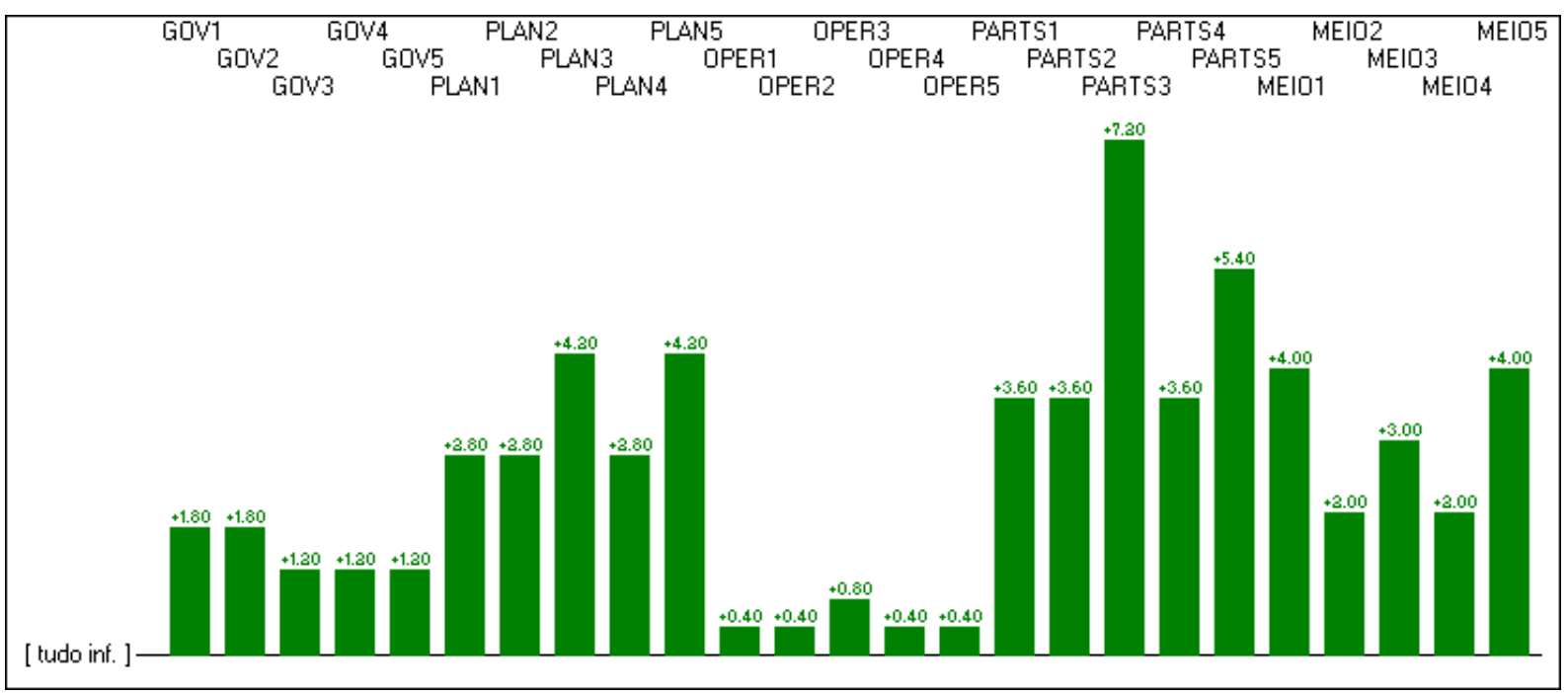

Gráfico 6.7 - Perfil de avaliações do Gestor 2.

A partir do Graf. 6.7 observa-se que de forma semelhante ao gestor 1, o gestor 2 atribui aos PVFs Participação Social e Planejamento as maiores avaliações. Sendo o PVF Operação o de menor aplicabilidade, porém em níveis menores que os apresentados pelo gestor 1 .

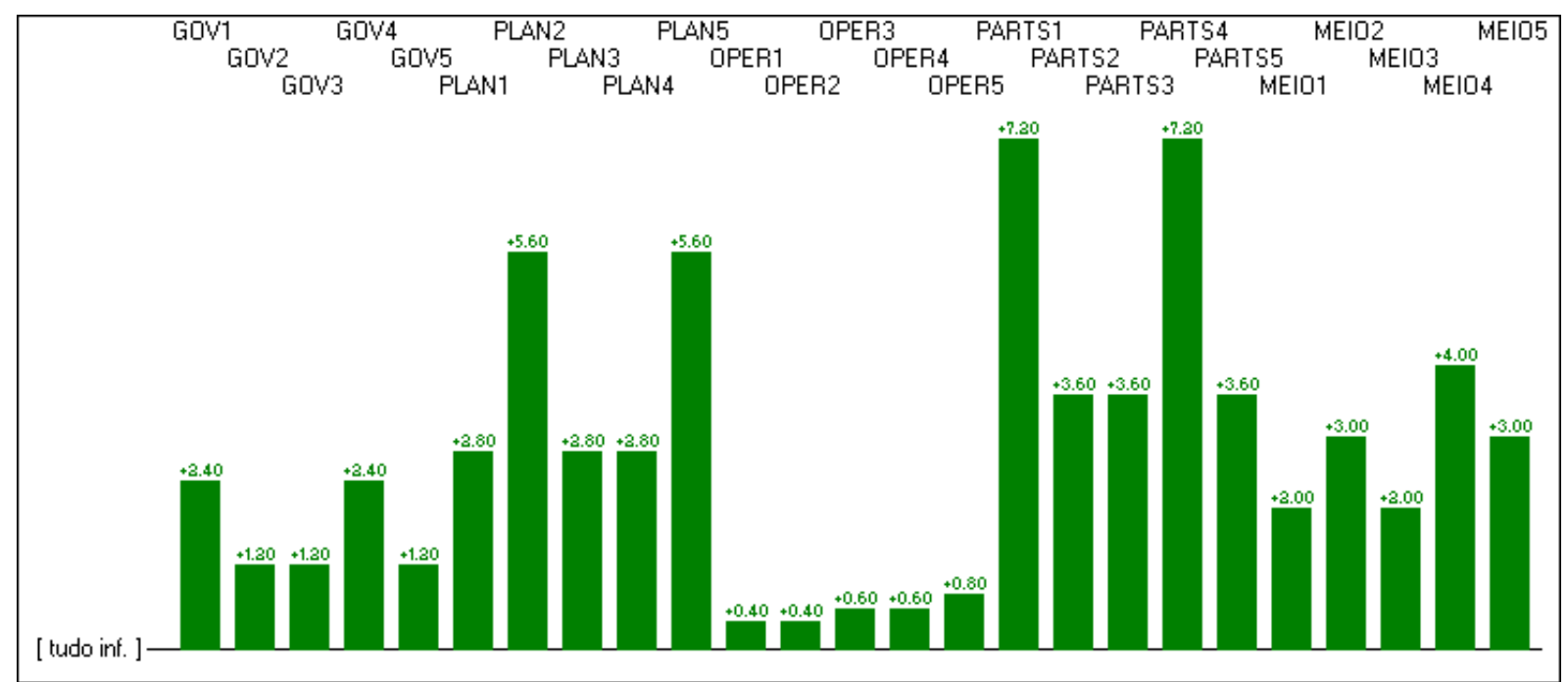

Gráfico 6.8- Perfil de avaliações do Gestor 3.

O Graf. 6.8 mostra o perfil de avaliações do gestor 3, o destaque ocorre no PVF Operação, constituindo o de menor aplicabilidade na política local. 


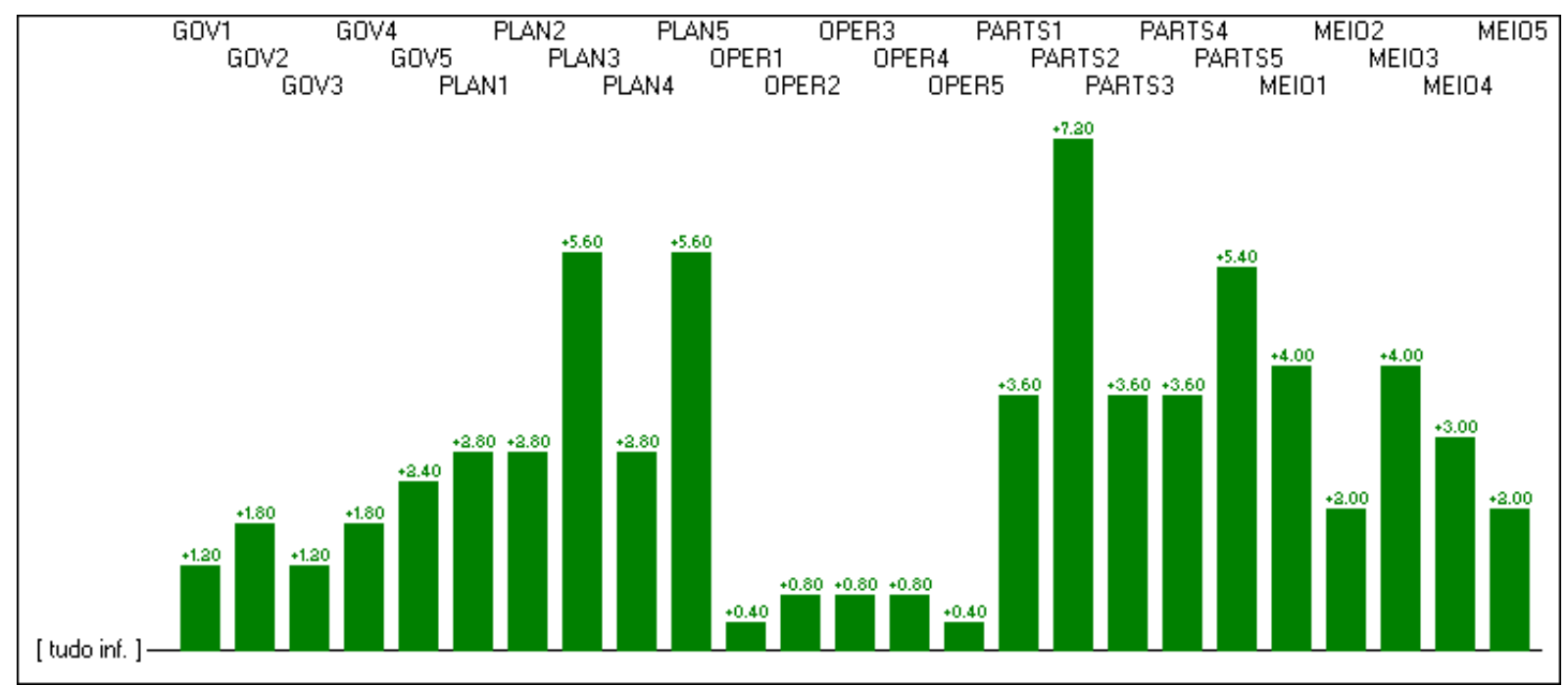

Gráfico 6.9 - Perfil de avaliações do Gestor 4

O Graf. 6.9 mostra o perfil de avaliações do gestor 4. Neste é possível perceber avaliações semelhantes às dos gestores 1 e 2, com uma maior aplicabilidade atribuída ao PVF Participação Social e um menor nível ao PVF Operação.

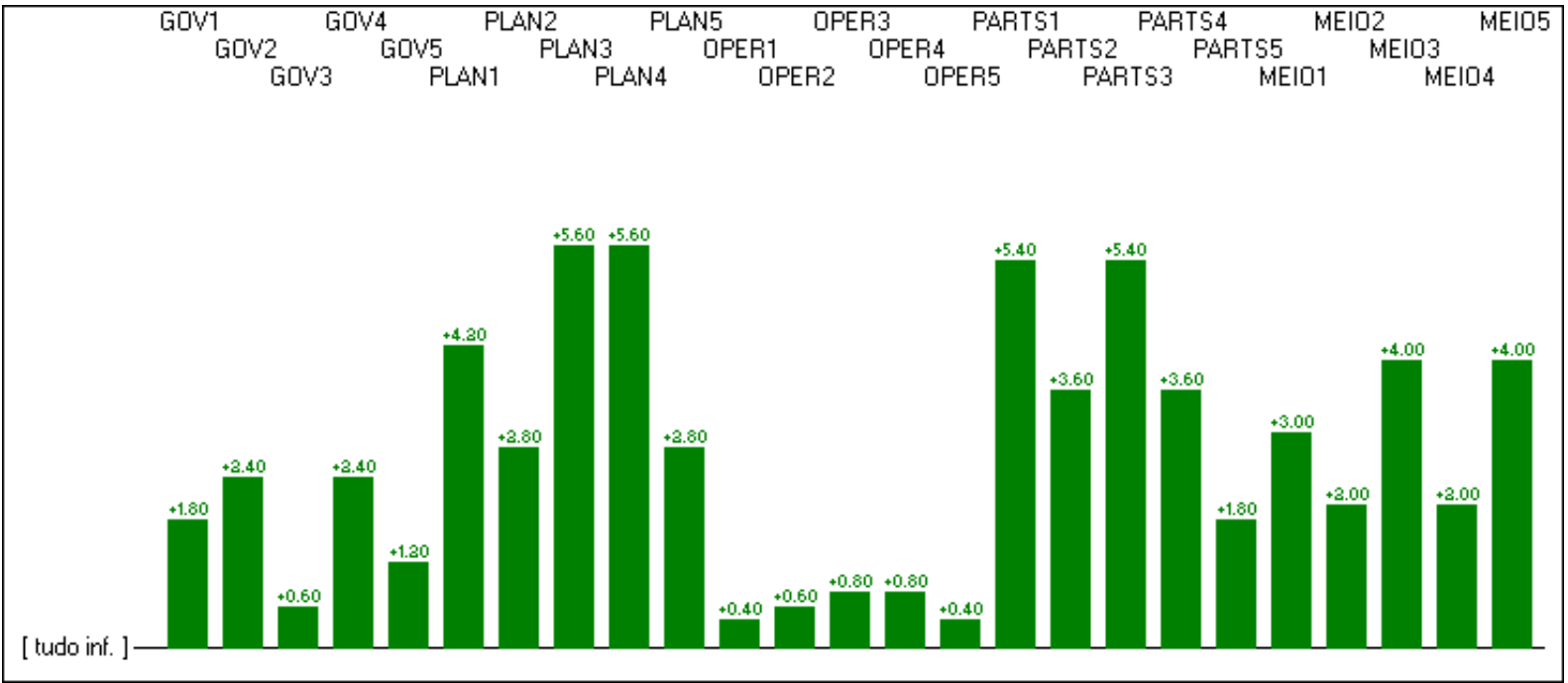

Gráfico 6.10 - Perfil de avaliações do Gestor 5.

O Graf. 6.10 apresenta o perfil de avaliações do gestor 5. O maior nível de aplicabilidade na política local ocorre no PVF Participação Social. Entretanto, diferente dos demais, atribui ao PVF Meio Ambiente um baixo nível de aplicabilidade, semelhante ao PVF Operações.

O programa M-Macbeth permite obter os perfis de diferenças entre gestores para cada PVF. Com essa funcionalidade, é possível observar pontualmente as diferenças de percepção da aplicabilidade da PMU em cada uma das cinco áreas: Governança, Participação Social, Meio Ambiente, Planejamento e Operações (Gráficos 6.11 a 6.20). 
As barras mostram as diferenças de pontuações nos critérios entre a primeira das duas opções selecionadas e a segunda; as diferenças positivas (barras verdes) correspondem aos critérios em que as performances da primeira das duas opções são mais atrativas que as performances da segunda opção; as diferenças negativas (barras laranja) correspondem aos critérios em que as performances da segunda das opções selecionadas são mais atrativas que as performances da primeira; uma diferença nula significa que as duas opções são igualmente atrativas no critério respectivo. (BANA e COSTA et al., 2005).

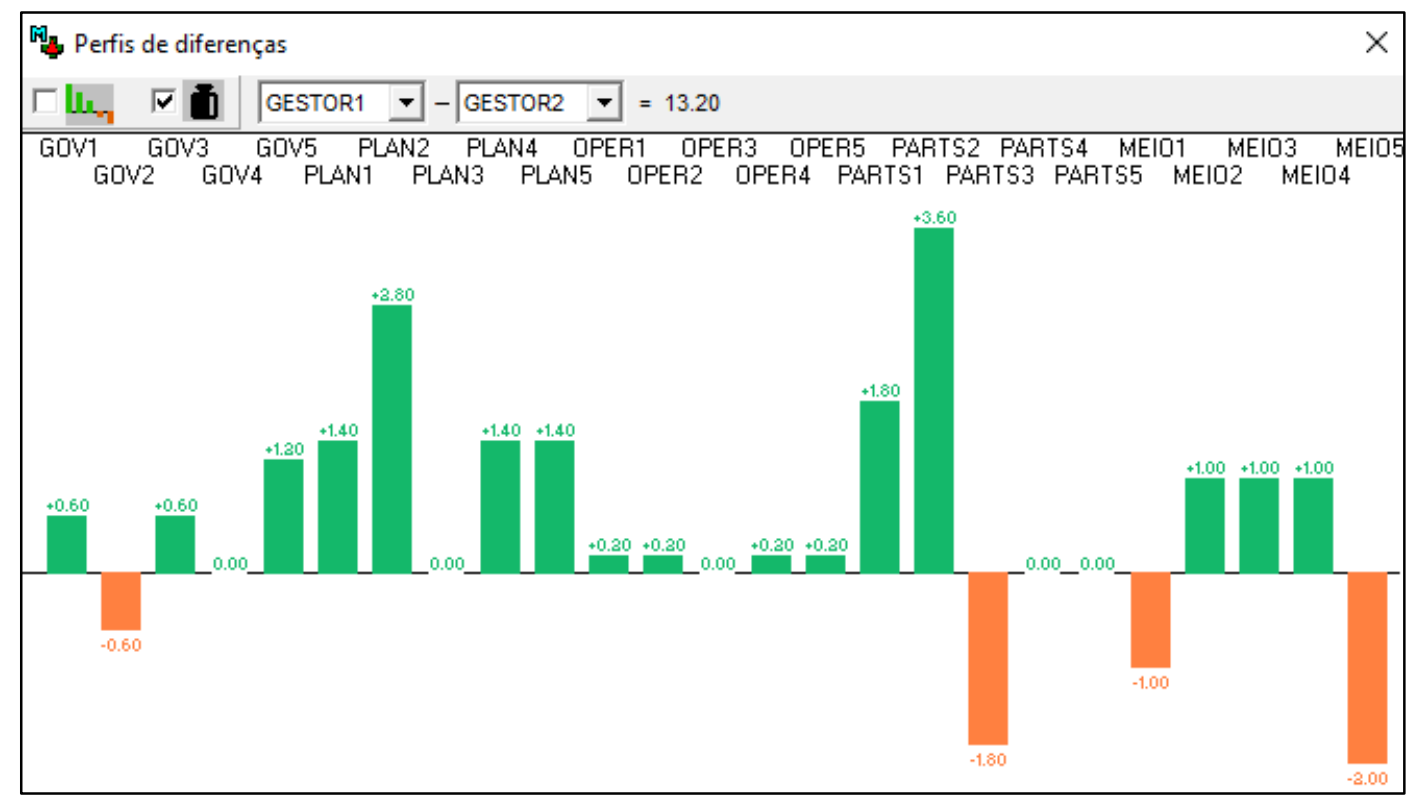

Gráfico 6.21 - Perfil de diferenças entre o Gestor 1 e o Gestor 2

O Graf. 6.11 apresenta o perfil de diferenças entre os gestores 1 e 2. As maiores distinções ocorrem no PVF Planejamento, e as menores, na aplicabilidade do PVF Participação Social.

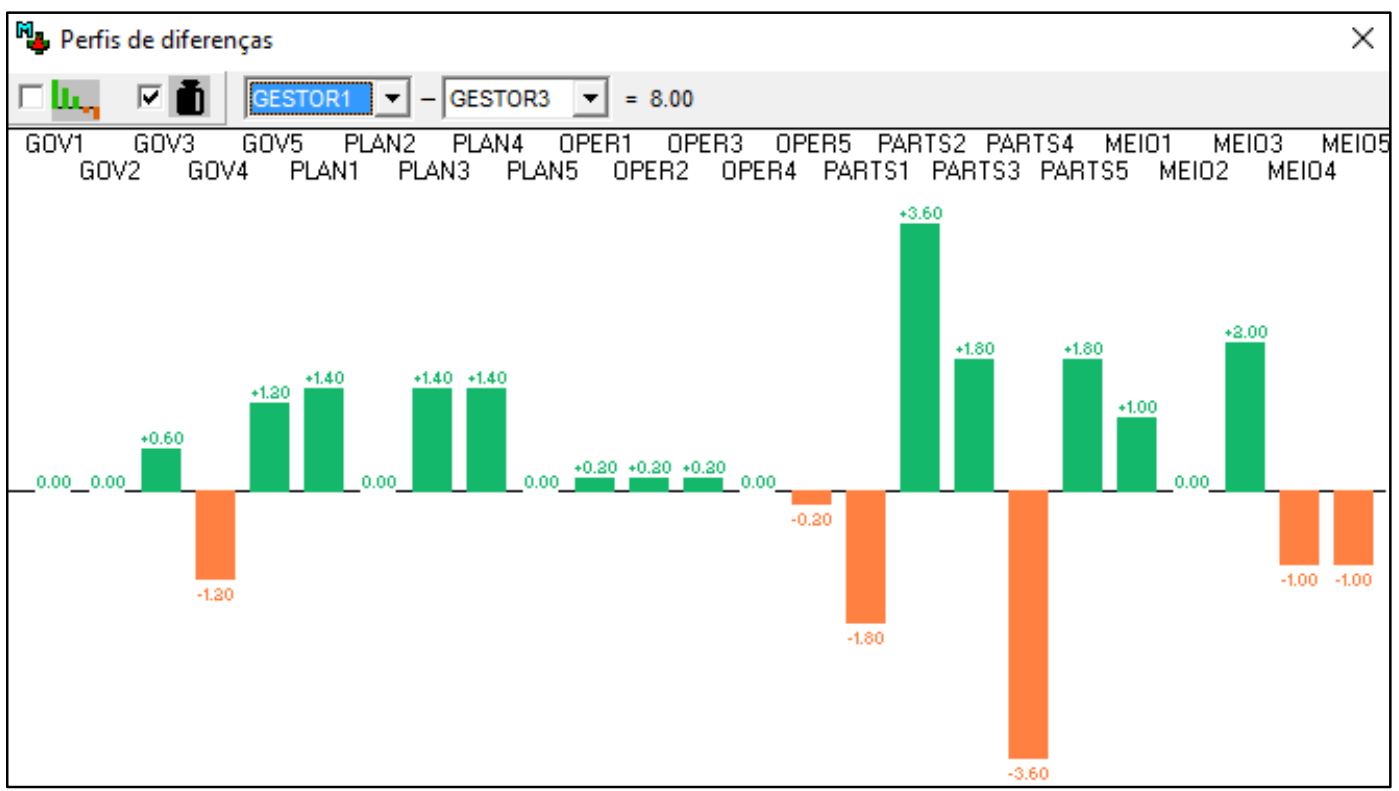

Gráfico 6.32 - Perfil de diferenças entre o Gestor 1 e o Gestor 3 
O Graf. 6.12 mostra o perfil de diferenças entre os gestores 1 e 3. Com base neste perfil, é observado um maior nível de aplicabilidade na avaliação de todos os PVFs, com destaque para o atributo Participação Social.

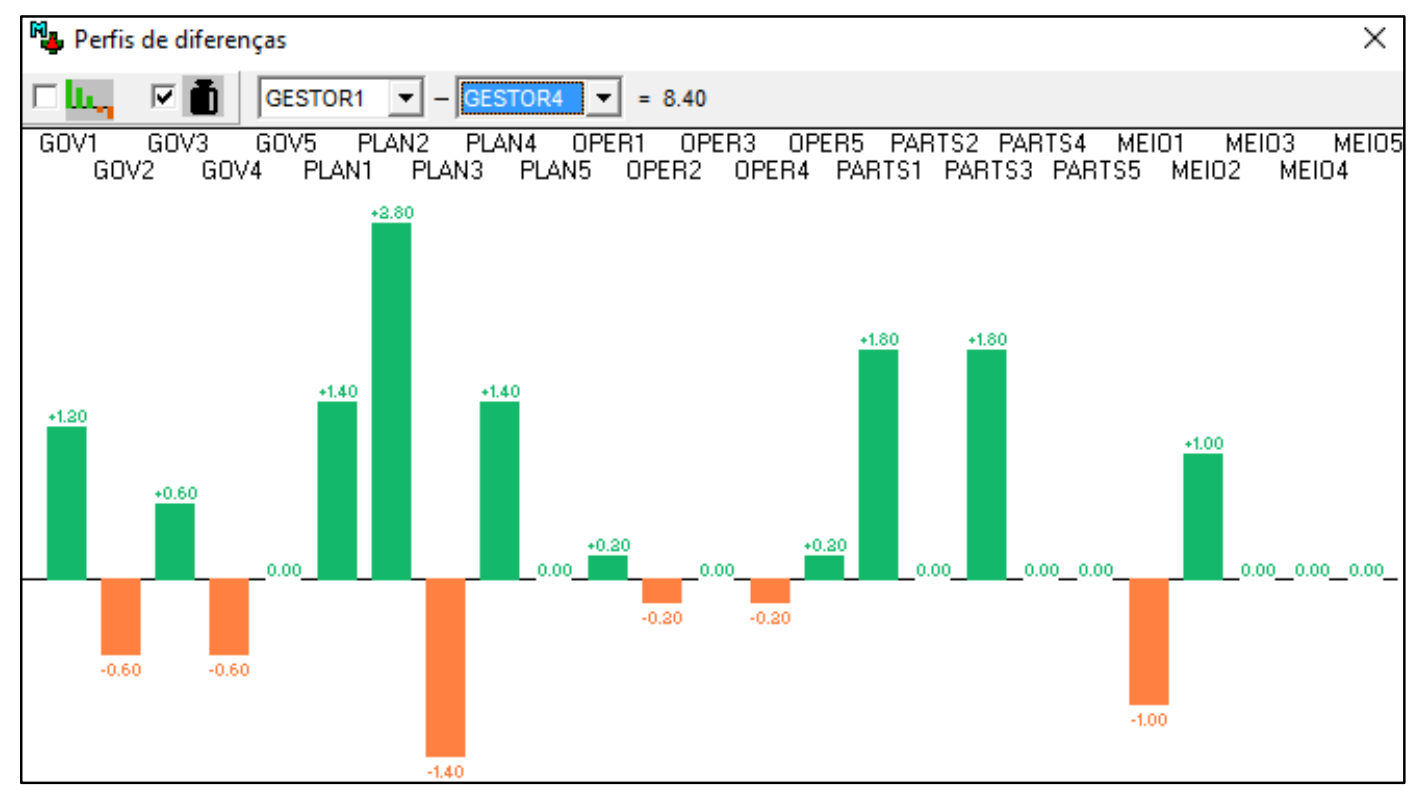

Gráfico 6.43 - Perfil de diferenças entre o Gestor 1 e o Gestor 4.

No Graf. 6.13, é apresentado o perfil de diferenças entre os gestores 1 e 4 . Este perfil é semelhante ao perfil do Graf. 6.12, porém com níveis menores de diferenças e com discrepâncias pontuais no PVF Participação Social.

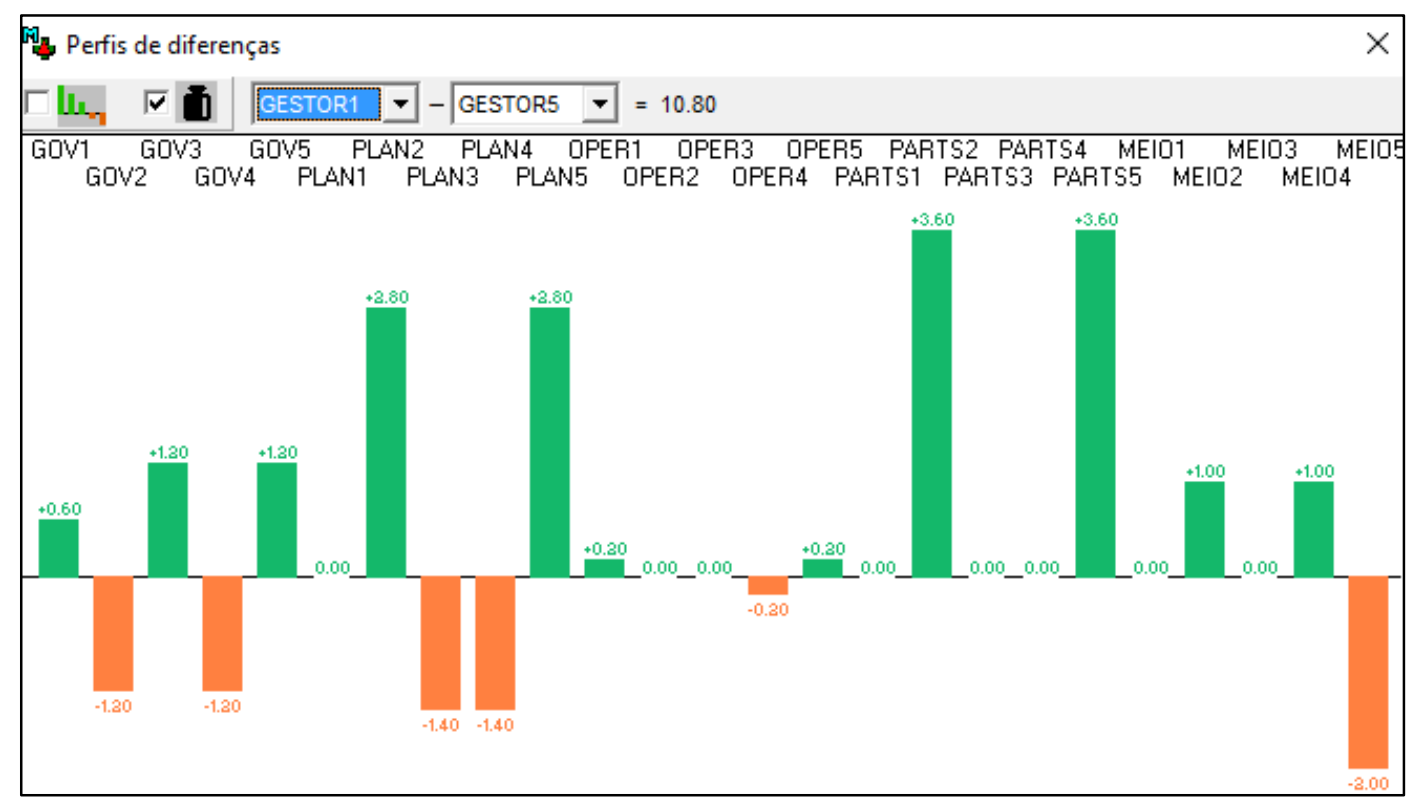

Gráfico 6.54- Perfil de diferenças entre o Gestor 1 e o Gestor 5 
O Graf. 6.14 apresenta o perfil de diferenças entre os gestores 1 e 5. É observado que a tendência de maiores avaliações da aplicabilidade dos PVFs se mantém no comparativo com os perfis anteriores.

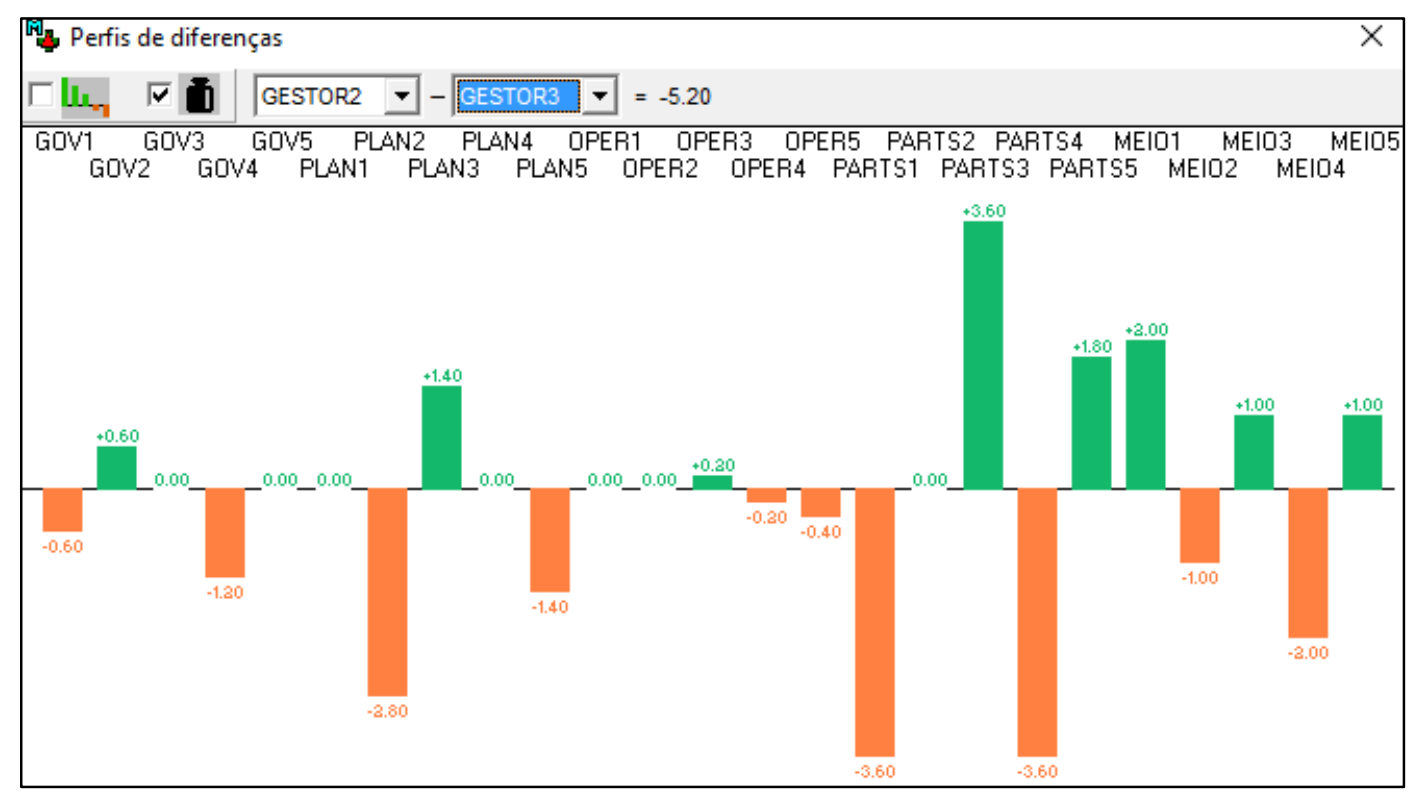

Gráfico 6.65 - Perfil de diferenças entre o Gestor 2 e o Gestor 3

No Graf. 6.15, é apresentado o perfil de diferença entre os gestores 2 e 3. Neste perfil, apesar de discrepâncias pontuais em alguns PVEs, constata-se ausência de diferenciações em quase metade desses pontos.

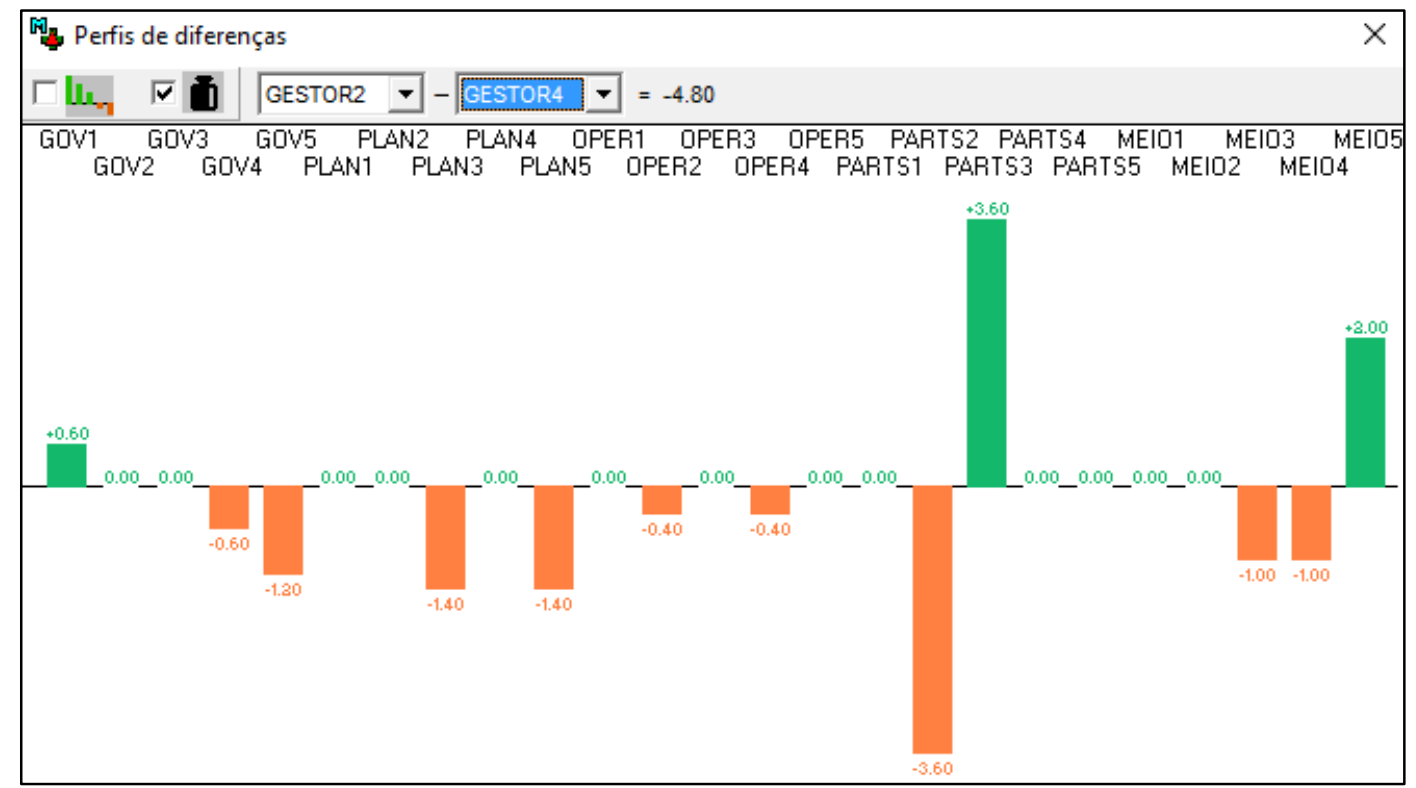

Gráfico 6.76 - Perfil de diferenças entre o Gestor 2 e o Gestor 4 
O Graf. 6.16 apresenta o perfil de diferenças entre os gestores 2 e 4. Em que pesem as diferenças de avaliações, estas compensam-se mutuamente, refletindo na nota de avaliação geral que indica valores semelhantes entre ambos os gestores.

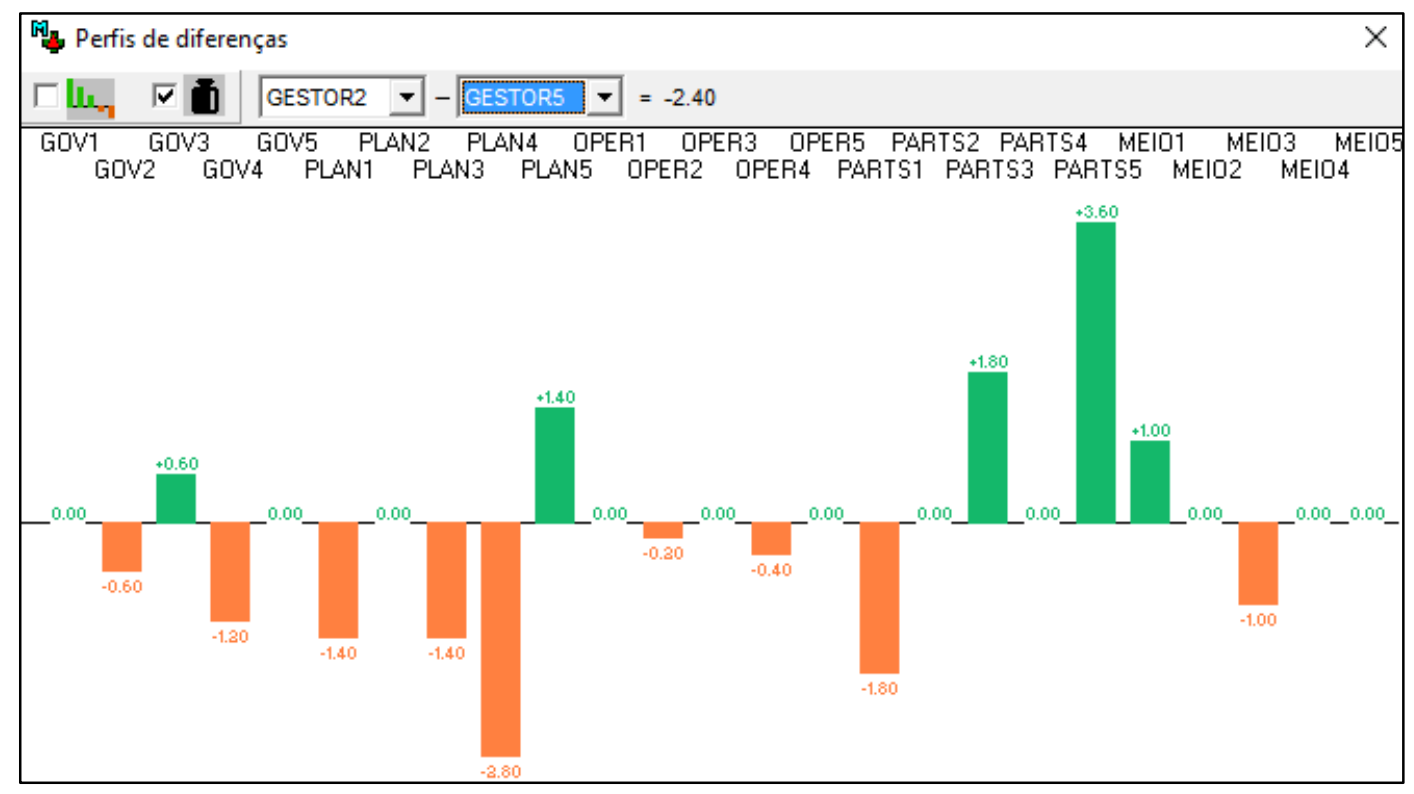

Gráfico 6.87 - Perfil de diferenças entre o Gestor 2 e o Gestor 5

No Graf. 6.17, é apresentado o perfil de diferenças entre os gestores 2 e 5 . As maiores diferenças ocorrem no PVF Meio Ambiente, e as menores, no PVF Operações.

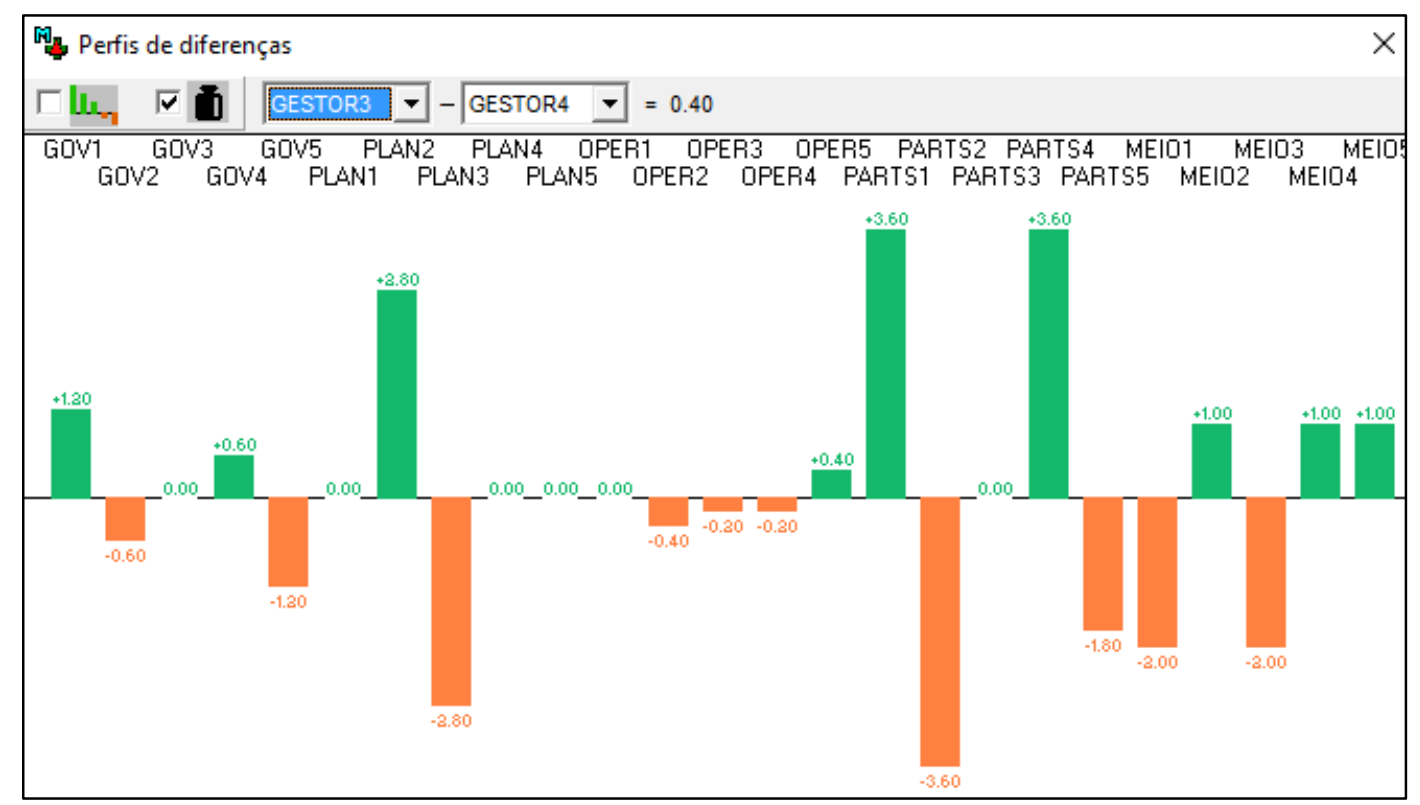

Gráfico 6.98 - Perfil de diferenças entre o Gestor 3 e o Gestor 4.

O Graf. 6.18 aponta o perfil de diferenças entre os gestores 3 e 4 . O gestor 3 apresenta em quase todos dos PVEs níveis de avaliações iguais ou menores que os apresentados pelo gestor 4. 


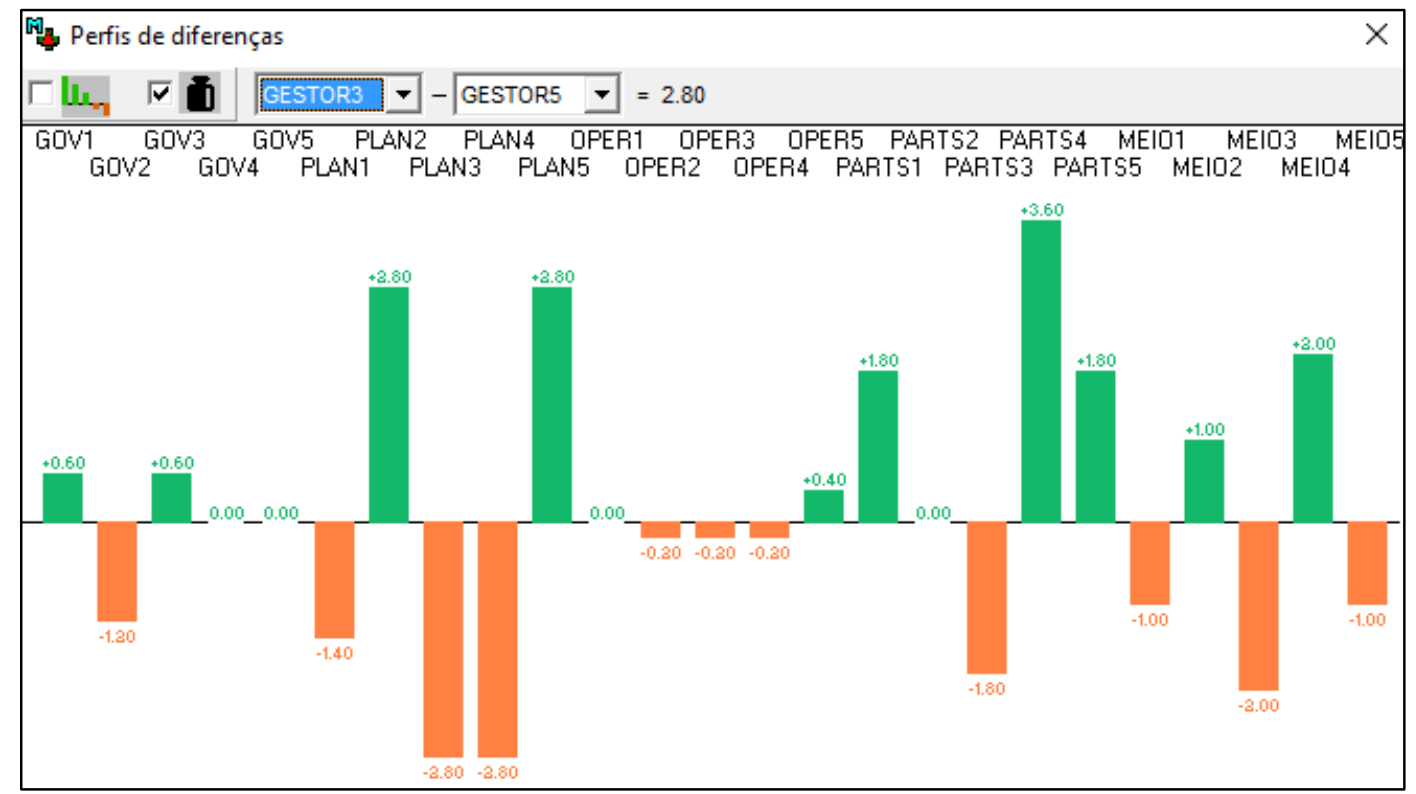

Gráfico 6.19- Perfil de diferenças entre o Gestor 3 e o Gestor 5

No Graf. 6.19, é indicado o perfil de diferenças entre os gestores 3 e 5 . As maiores distinções ocorrem nos PVFs Participação Social e Planejamento. Entretanto, a nota final de avaliação destes gestores é semelhante, ao passo que as diferenças se compensam.

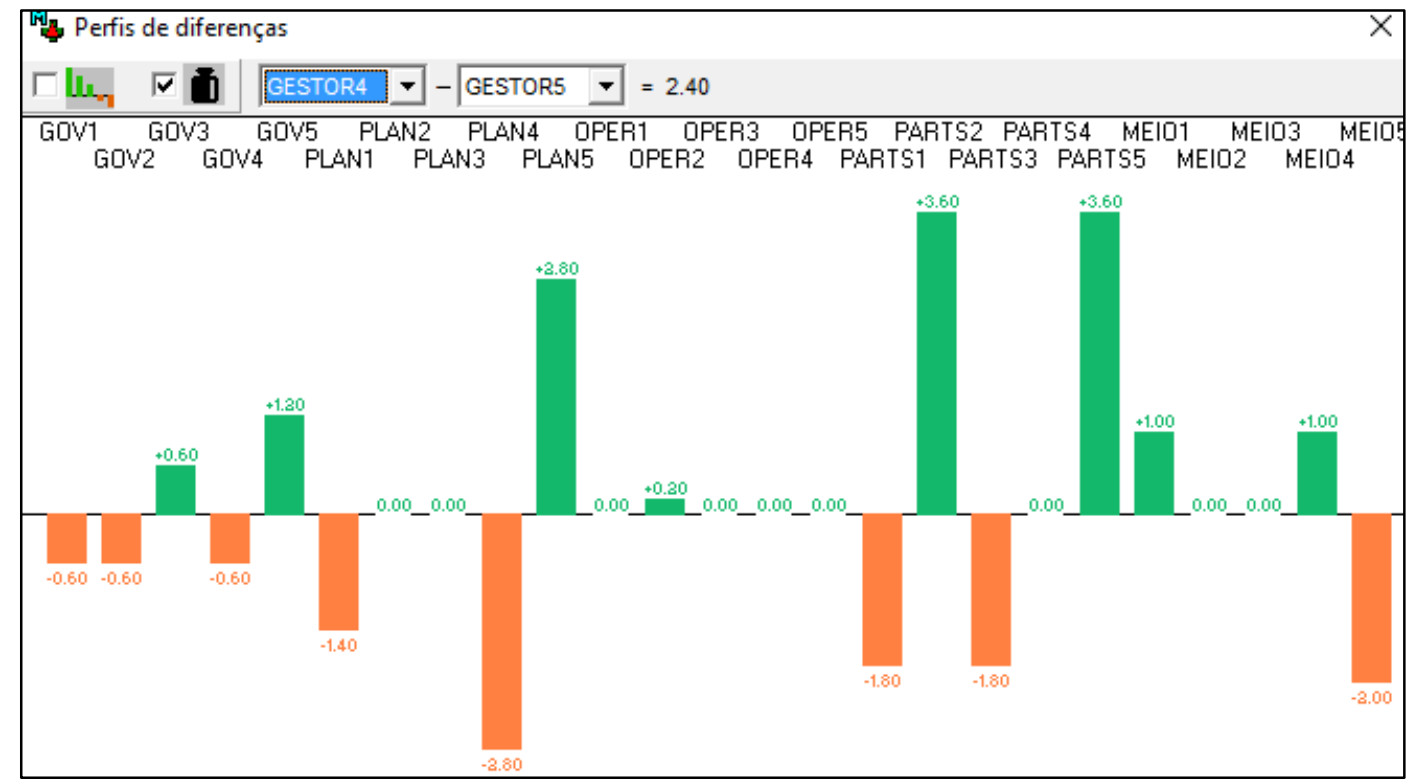

Gráfico 6.100- Perfil de diferenças entre o Gestor 4 e o Gestor 5

O Graf. 6.20 apresenta o perfil de diferenças entre os gestores 4 e 5. A partir da análise desse perfil, é possível observar que o PVF Meio Ambiente apresenta maior discrepância nas avaliações. O PVF Participação Social, apesar de possuir um PVE divergente, não apresenta diferenciação nos demais PVEs da composição. O programa M-Macbeth, a partir das 
avaliações, fornece o índice global com base nas atribuições de cada gestor, compondo, por conseguinte, a Fig. 6.5 e a Tab.6.4.

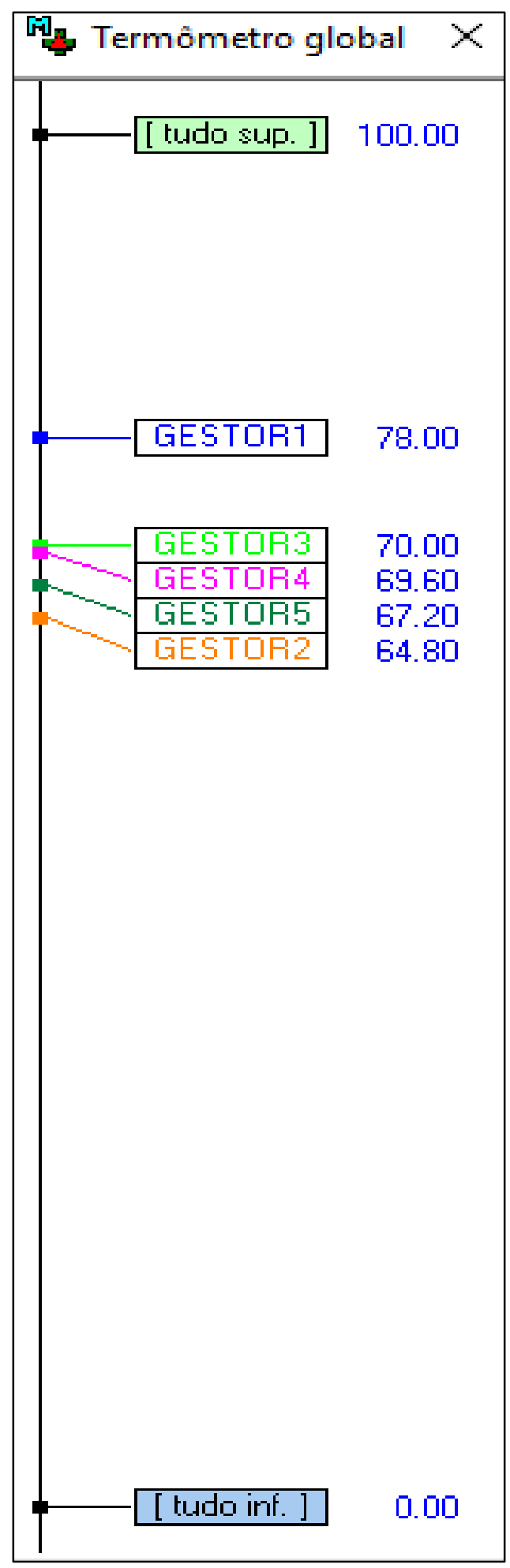

Figura 6.9 - Termômetro global para o Estudo de Caso 
Tabela 6.4 - Tabela de pontuações globais

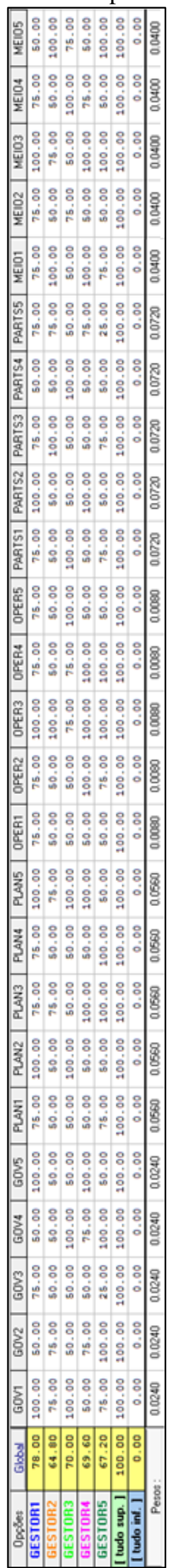


Por meio do cálculo da mediana, encontrou-se como IPMU o valor de 69,60. Portanto, dentro da zona de admissibilidade, conforme é apresentado no Graf. 6.21.

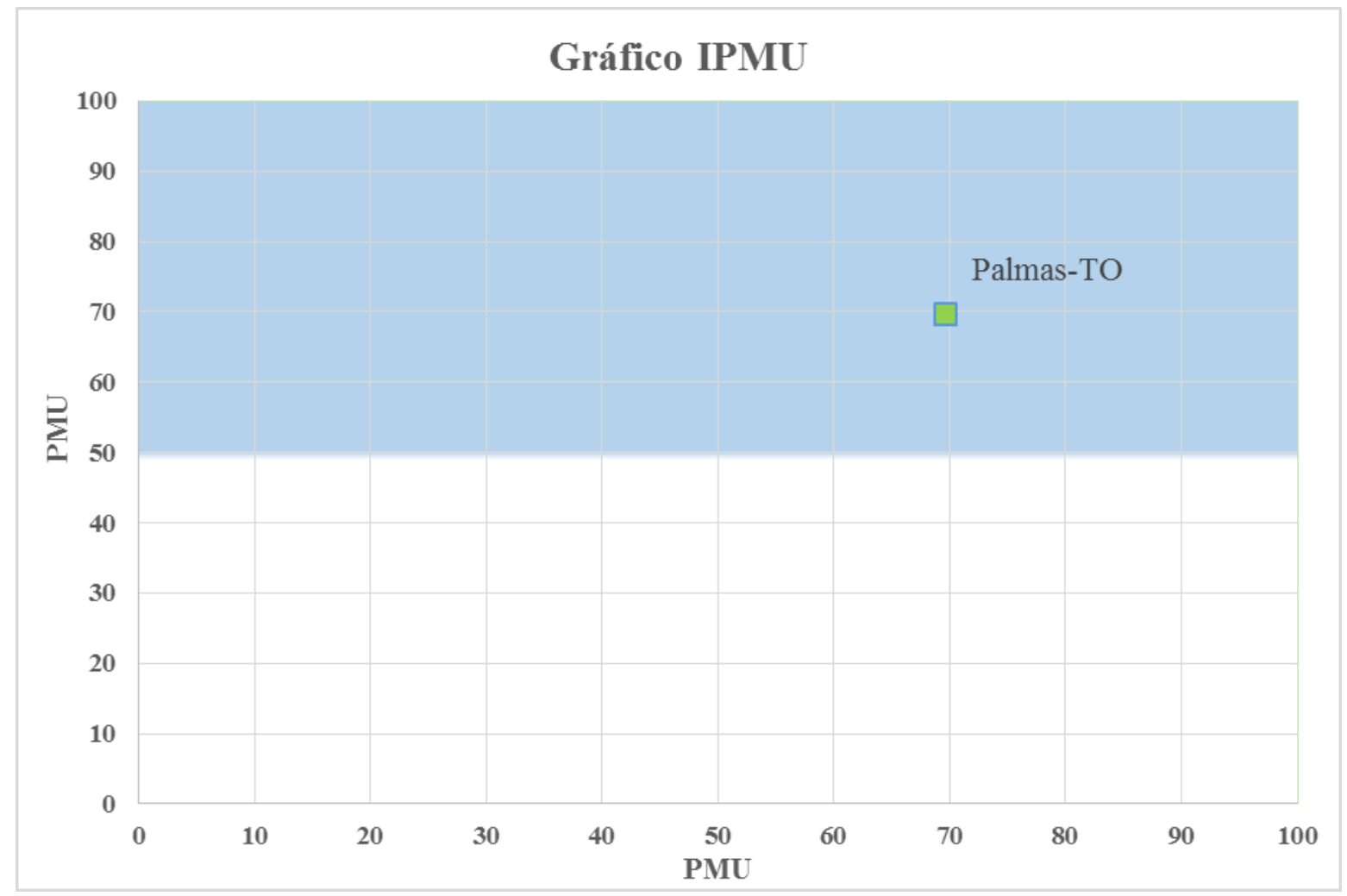

Gráfico 6.111 - Índice da Política de Mobilidade Urbana (IPMU) - Palmas-TO

\subsection{TÓPICOS CONCLUSIVOS}

A cidade de Palmas, última cidade brasileira planejada do século XX, foi avaliada sob a ótica da metodologia, seguindo todos os procedimentos adotados na simulação realizada com os três municípios fictícios do capítulo 5. A pesquisa mostra, em caso concreto, todo o arsenal disponível pelo método, avaliando de forma específica a área de mobilidade do município.

A avaliação em caso concreto se mostrou eficaz, a participação dos elementos de avaliação foi seguida à risca pela metodologia: pesquisador, decisor e gestores. Nesse aspecto, convém denotar que os dados da Matriz de Preferência foram retirados da entrevista com o decisor, enquanto que os dados dos gestores foram coletados por meio da aplicação de questionários, sob a ótica dos Critérios de Avaliação adotados neste trabalho.

Na ótica da avaliação, alguns pontos merecem destaques, como a "preferência" política dada pelo decisor ao critério Participação Social, o que pode sugerir uma agenda mais aberta no que tange a PMU do município. Outro ponto é a discrepância entre os gestores 1 e 2 no âmbito da 
execução da estratégia adotada pelo decisor. Por último, de forma mais evidente, as diferenças entre o que aponta a preferência do decisor e as preferências dos gestores responsáveis pela execução. O que permite concluir que o processo de avaliação pode contribuir para melhoria da sinergia entre o ambiente político e o técnico, entre estratégia e execução.

O município, por meio da aplicação do método, obteve um índice de 69,60, ou seja, acima do patamar mínimo de 50,0. Destarte, conclui-se que Palmas, capital do estado do Tocantins, está dentro da zona de admissibilidade requerida pelo pesquisador e possui, em certo índice, gestão estratégica aderente aos princípios, diretrizes e objetivos da Lei de Mobilidade. 


\section{CONCLUSÕES E RECOMENDAÇÕES}

Este capítulo apresenta as conclusões obtidas no trabalho, abordando os aspectos das questões de pesquisa e das hipóteses levantadas no Capítulo 1. Serão apresentadas, também, recomendações para trabalhos futuros.

\subsection{CONCLUSÕES}

A avaliação de política pública está apoiada no ato de verificar como uma política de fato está funcionando na prática, no qual envolve avaliação dos meios empregados visando ao atendimento dos objetivos programáticos. Tendo como fundamento o embasamento teórico e metodológico, as conclusões deste estudo concorrem a esclarecer que, diante de tantas variáveis envolvidas na avaliação de uma política pública, e dada a ausência de indicadores efetivos da PNMU, o trabalho produziu um enfoque mais gerencial aos questionamentos da pesquisa.

Nessa arena específica, o anseio de atender aos princípios e de executar as diretrizes e os objetivos da Lei é revelado por meio da efetividade do processo de tomada de decisão política. Desse modo, o trabalho dá sua contribuição, criando um instrumento de avaliação capaz de medir municípios no contexto da gestão estratégica, provendo uma avaliação política setorizada no campo da mobilidade.

O resultado final, expresso na aplicação da metodologia, tanto no capítulo das simulações, quanto no capítulo do estudo de caso, converge para um parâmetro de avaliação da gestão estratégica do município à luz da mobilidade urbana. Nesse contexto, o método acata a hipótese erguida no Capítulo1, de que "é possível realizar a avaliação da PNMU sob a ótica da gestão estratégica, por meio da criação de Critérios de Avaliação retirados da lei 12.587/2012, mesmo que os critérios apontados pela própria Lei careçam de maior objetividade". Nesse sentido, a metodologia desenvolvida e aplicada, apoiada pela ferramenta Macbeth, consegue mitigar as variáveis subjetivas.

A ferramenta se aplica em qualquer município que esteja sob a obrigatoriedade de adotar a Lei 12.587/12. A conclusão é dada de forma objetiva por meio da combinação de critérios de avaliação e o software M-Macbeth. Todos os fatores subjetivos são traduzidos em uma nota de avaliação, dessa forma, qualquer usuário da metodologia poderá comparar a avaliação final com 
um patamar mínimo de referência, e assim mensurar a efetividade da gestão estratégica envolvendo decisores e gestores da PMU do Município.

Vale destacar que os diferentes tomadores de decisão, que operam em ambientes institucionais semelhantes, podem dar respostas diferentes, mesmo quando lidam com problemas semelhantes. Por essa razão, ainda que ocorram processos operacionais padronizados em suas rotinas, amparados pela mais rigorosa técnica de execução, mesmo assim o resultado final da tomada de decisão poderá ser diferente. Isso se deve ao contexto estrutural e institucional de cada situação que envolve o tomador de decisão.

Os resultados apontados nas simulações comprovam a afirmação anterior, que poderá haver resultados distintos entre municípios, já que não há como "padronizar vontades e percepções", o que não significa falha do método, apenas a diferença de preferências, haja vista que os critérios se mantêm íntegros no processo. A ferramenta ainda disponibiliza mecanismos para comparar gestores no mesmo bloco de critérios e também de forma global, estabelecer uma nota de referência a cada gestor (executor).

A ferramenta criada revela também, de forma direta, a sinergia ou o descompassos entre o direcionamento estratégico do decisor e o desdobramento tático e operacional realizados pelos gestores, que são os executores da PMU do município. Nesse aspecto, há de se avaliar o fluxo de correção da tomada de decisão, criando novas agendas ou fortalecendo agendas existentes, no sentido de alterar o status quo político e retroalimentar o processo de tomada de decisão iniciando outro ciclo. Infere-se aqui, também, a opção do município em manter o status quo, ratificando o desinteresse da agenda de mobilidade.

Para extrair o máximo da metodologia no processo de avaliação da política de mobilidade, deve-se levar em conta a natureza subjetiva do método, sem preconceito. Um caráter pessoal de avaliação não impede que aconteçam julgamentos significativos e importantes à luz da estratégia local. Cabe sim olhar o processo como uma combinação de elementos que atuam sob uma matriz positivista e construtivista, com a finalidade de avaliar e prover embasamento ao gestor público no processo de tomada de decisão da PMU.

$\mathrm{Na}$ avaliação do estudo de caso, realizado no município de Palmas, observa-se que o índice gerado refuta a hipótese alçada no capítulo 1, que "a gestão estratégica da mobilidade, desenvolvida no espaço público municipal, não cumpre requisitos fundamentais previstos na Lei de Mobilidade, sendo um fator limitante o desalinhamento estratégico das estruturas 
implementadoras de gestão". O município de Palmas, capital do estado do Tocantins, apresentase dentro da zona de admissibilidade, diante da avaliação metodológica aplicada, o que permite concluir que a sua gestão estratégica cumpre requisitos fundamentais previstos na Lei $12.587 / 2012$.

\subsection{RECOMENDAÇÕES}

Para Howlett, Ramesh e Perl (2013), avaliar políticas públicas no âmbito da gestão é bastante desafiador, pois é possível que o "governo local” queira estabelecer os termos de avaliação, ou o processo pode sofrer a exclusão de algum critério não trabalhado politicamente. Ou de outra maneira, a gestão local pode negar-se a colaborar com a pesquisa. Esses pontos não foram vivenciados na construção deste trabalho, mas cabe destacar a dificuldade encontrada em estabelecer uma agenda de entrevista junto ao decisor, logo, recomenda-se atenção nessa fase.

O trabalho deixa espaço para grandes contribuições quanto à aplicação da ferramenta criada. Nesse sentido, há como ampliar o campo de estudo por meio de uma matriz comparativa de municípios, seja dentro do mesmo estado ou entre regiões distintas, ex.: municípios da Região Norte com a Região Sudeste, provocando reflexões e comparações diante do cenário de aprovação de projetos de mobilidade junto ao governo federal. Baseado na avaliação estratégica do município, quanto ela reflete na tomada de recursos financeiros junto a fontes de financiamento para a mobilidade urbana?

Outra forma construtiva de aproveitar a ferramenta é aumentar o número de critérios de avaliação e aplicá-los em grandes metrópoles dentro de um contexto mais exaustivo de aplicação da PNMU. Por outro lado, o ajuste dos critérios a municípios menores também é importante, e essa avaliação pode ser realizada por faixa populacional, tendo como caráter definidor o número de habitantes, buscando encontrar a estrutura e a capacidade técnica ideal para colocar em prática planos de mobilidade.

De forma mais profunda, pode-se utilizar a ferramenta concomitantemente com a avaliação de indicadores da PNMU, elencado pelo Ministério das Cidades, onde o cenário de avaliação permitirá confrontar o resultado da gestão estratégica com o score global do município. Nesse contexto, o cenário de avaliação seria mais abrangente, a ponto de aproximar a avaliação técnica da avaliação política, elencado um panorama mais completo do estudo da Lei 12.587/2012. 


\section{REFERÊNCIAS BIBLIOGRÁFICAS}

ABRUCIO, F. L. A coordenação federativa no Brasil: a experiência do período FHC e os desafios do governo Lula. Revista de Sociologia e Política, n 24, 2005.

ABRUCIO, F. Os barões da federação: os governadores e a redemocratização brasileira/fernando Abrucio - São Paulo: Hucitec/departamento de Ciência politécnica, USP, 1998.

ANTP - Associação Nacional de Transportes Públicos. Sistema de Informações da Mobilidade Urbana. Relatório Geral 2012 - julho/2014. Disponível em: < http://antp.org.br/>. Acesso em: 30 de ago. 2016.

ARANTES. O. A cidade do pensamento único: desmanchando consensos / Otília Arantes, Carlos Vainer, Ermínia Maricato. - Petrópolis, RJ : Vozes, 2000.

ARRETCHE, M. Financiamento Federal e Gestão Local de Políticas Sociais: o difícil equilíbrio entre regulação, responsabilidade e autonomia ciência e saúde coletiva. Rio de janeiro: v8, n², 2002.

BANA E COSTA, C.A. \& Vansnick, J.C. (1995). Uma nova abordagem ao problema da construção de uma função de valor cardinal: MACBETH. Investigação Operacional, 15, 15-35.

BANA e COSTA, C.A. Structuration, Construction et Exploitation d'un Modèle Multicritère d'Aide à la Décision. Tese de Doutorado, Universidade Técnica de Lisboa, Portugal, 1992.

BANA E COSTA, C.A.; De Corte, J.M. \& Vansnick, J.C. (2005). On the mathematical foundations of Macbeth. In: Multicriteria Decision Analysis: state of the art survey [edited by J.F. Greco and S.M. Ergot], Springer Verlag, Boston, Dordrecht, London, 409-442.

BARAT, J. Questão institucional e financiamento dos transportes urbanos no Brasil: o caso da região Metropolitana de São Paulo. Transportes coletivos urbanos - Cadernos Fundap, ano 6, n.12, p. 10-27. São Paulo, 1986.

BERCOVICI, Gilberto. Dilemas do estado federal brasileiro. Porto Alegre: Livraria do Advogado Ed., 2004. 104p.

BONDUKI, N. G. Origens da habitação social no Brasil: o caso de São Paulo. 1994. Tese (Doutorado). Faculdade de Arquitetura e Urbanismo, Universidade de São Paulo. São Paulo. 1994.

BONDUKI, N. Política habitacional e inclusão social no Brasil: revisão histórica e novas perspectivas no governo Lula. Revista de Arquitetura e Urbanismo, São Paulo, n.1, p.70-104, 2008.

BRACKER, J. The historical development of the strategic management concept, The Academy of Management Review, v. 5, iss. 2, abr., p. 219- 224, 1980.

BRASIL. Constituição Federal de 1988. Planalto.gov.br. Disponível em:< http://www.planalto.gov.br/>. Acesso em: 22 de jun. 2016. 
BRASIL. Estatuto da Cidade: Lei n.10.257, de julho de 2001, que estabelece diretrizes gerais da política urbana. Brasília: planalto.gov.br. Disponível em <http://www.planalto.gov.br/>. Acesso em: 20 de mar. 2016.

BRASIL. INSTITUTO BRASILEIRO DE GEOGRAFIA E ESTATÍSTICA. Perfil dos Municípios brasileiros 2012. Pesquisas de informações básicas municipais. Rio de Janeiro: IBGE, 2013.

BRASIL. Lei de Mobilidade Urbana Sustentável: Lei n.12.587, de janeiro de 2012, Institui as diretrizes da Política Nacional de Mobilidade Urbana. Brasília: planalto.gov.br. Disponível em:< https://www.planalto.gov.br/>. Acesso em: 28 de abr. 2016.

BRASIL. MINISTÉRIO DAS CIDADES. O Estatuto da Cidade: comentado. Brasília: Ministério das Cidades, São Paulo: Aliança das Cidades, 2010.

BRASIL. MINISTÉRIO DAS CIDADES. PlanMob: Caderno de Referência para Elaboração de Plano de Mobilidade Urbana. Brasília: Ministério das Cidades, 2015.

Brewer, Garry D., and Peter deLeon. The Foundation of Policy Analysis. Pacific Grove, CA: Brooks/Cole, 1983.

BRYNER, G.C. Bureaucratic Discretion. Law and policy in Federal Regulatory Agencies. Nova York: Pergamon, 1987.

CHAPMANN, R. A Ethics in the Public Service for the New Millennium. Aldershot: Ashgate, 2000.

CHIAVENATO, Idalberto. Introdução à teoria geral da administração. 6 ed. Rio de Janeiro: Campus, 2000.

CICONELLO, A. A Participação Social como processo de consolidação da democracia no Brasil, 2008. Disponível em:<http://cebes.org.br/>. Acesso em: 20 de jul. 2016.

DONALDSON, Thomas; PRESTON, Lee E. The stakeholder theory of the corporation: concepts, evidence and implications. Academy of Management Review. Ada, v.20, n.1, p.6591, 1995.

DYE, Thomas R. (2005). Mapeamento dos modelos de análise de políticas públicas. In Heidemann, F. G.; Salm, J. F. (2010). Políticas Públicas e Desenvolvimento. Brasília: Editora UnB.

EDEN, C., Jones, S., Sims, D. Messing About in Problems. Oxford: Pergamon, 1983.

ENSSLIN, L.; MONTIBELLER, G. N.; NORONHA, S. M. Apoio à decisão: metodologias para estruturação de problemas e avaliação multicritério de alternativas. Florianópolis: Insular, 2001.

FAGNANI, E. CADAVAL, M. A Constituição e o novo cenário da política social, caso do transporte coletivo urbano. In FUNDAp, São Paulo, 1988.

FAHEY, L. The strategic planning management reader. Englewood Cliffs/New Jersey: Prentice Hall, 1989. 
FREEMAN, R. Edward. Strategic management: a stakeholder approach. Boston: Pitman, 1984.

GOHN, M.G. Conselhos Gestores na política social urbana e participação popular. São paulo. Caderno metrópole, n.7, pp. 9-31, 2002

GOMES, L. F. A. M.; ARAYA, M. C. G.; CARIGNANO, C. Tomada de decisões em cenários complexos: introdução aos métodos discretos do apoio multicritério à decisão. São Paulo: Pioneira Thomson Learning, 2004.

GOMIDE, A. A. Agenda governamental e o processo de políticas públicas: o projeto de lei de diretrizes da política nacional de mobilidade urbana. Texto para discussão $n^{\circ} 1334$. Brasília, abril de 2008. Disponível em: 〈http://repositorio.ipea.gov.br/>. Acesso em: 07 de set. 2016.

HELDMAN, Kim. Gerência de Projetos. PMP Project Management Professional. Guia para o Exame Oficial do PMI. 3a . Edição revista e atualizada. Rio de Janeiro: Elsevier, 2006.

HERRERO FILHO, E. Pessoas focadas na estratégia; as disciplinas da execução da estratégia / Emilio Herrera Filho. Rio de Janeiro: Elsevier, 2011.

HOWLETT, Michael; RAMESH, M; PERL, Anthony. Políticas Públicas: seus ciclos e subsistemas - uma abordagem integradora. Rio de Janeiro: Elsevier, 2013.

JANNUZZI, P. M.; MIRANDA, W. L. de; SILVA, D. S. G. da. Análise multicritério e tomada de decisão em políticas públicas: aspectos metodológicos, aplicativo operacional e aplicações. Informática Pública, Belo Horizonte, ano 11, n. 1, p. 69 - 87, 2009.

JARDIM, S.B. A cobrança eficiente pela garantia de ter e pelo uso da água disponível no ambiente: proposta de um modelo de gestão. Porto Alegre, 2003. Disponível em: <https://www.lume.ufrgs.br/>. Acesso: 07 de jul. 2016.

JONES, Thomas M.; WICKS, Andrew C. Convergent Stakeholder Theory. Academy of Management Review. Briarcliff Manor, v.24, n.2, p.206-222, Apr. 1999.

KAPLAN, R; NORTON, D. A Estratégia em Ação: Balanced Scorecard. Rio de Janeiro. Campus. 1997.

KAPLAN, Robert S., NORTON, David P. A Estratégia em Ação. Editora Campus, 1997.

KEENEY, R.L., and McDaniel's, T.L. (1992), "Value-focused thinking about strategic decisions at BC Hydro", Interfaces 22 6, 94-:109i.

KNEIB. E.C. Projeto e cidade: centralidades e mobilidade urbana. Goiânia: Gráfica UFG 2014.

KOTLER, Philip; KELVIN, Kevin Lane. Administração de Marketing. São Paulo: Ed. 12a Pearson Prentia Hall, 2006.

KUHN, T. S. A estrutura das revoluções científicas. 9. edição. São Paulo: Perspectiva, 2006.

LONGARAY, A. A., CAPRARIO, G. N., ENSSLIN, L. (2010). Análise de decisão multicritério: um caso empregando o MACBETH. SINERGIA: Revista do Instituto de Ciências Econômicas, Administrativas e Contábeis da Universidade Federal do Rio Grande, 14(2), 51 62. 2010. 
LONGARAY, A. A.; ENSSLIN, L. (2013). Uma proposta de integração da softs systems methodology à MCDA-C. Rio de Janeiro, v.5, n.3, p. 331-372, setembro a dezembro de 2013. Disponível em: <http://repositorio.furg.br/>. Acesso: 25 de set. 2016.

LYNN JR, Laurence E. Gestão pública In: PETERS, G.B., Pierre, J. (Org.). Administração Pública - coletânea. São Paulo: Ed. UNESP; Brasília: ENAP, 2010.

MANCINI, M. T.: RODRIGUES DA SILVA, A. N. Padrões de geração de viagens e mobilidade urbana sustentável. Revista Transportes, v, XVIII, n.1, p.36-45, 2010.

MARICATO, E. Metrópole, legislação e desigualdade. São Paulo: Estudos Avançados 17 (48), 2003.

MARICATO, E. O impasse da política urbana no Brasil. Petrópolis: Vozes. 2011.

MARICATO, Ermínia e Santos Junior, Orlando Alves dos Santos. In Teoria e Debate, n. ${ }^{\circ}$ 66, abr-jun 2006. Disponível em: <http://gestaocompartilhada.pbh.gov.br/>. Acesso em 03 de jun. 2016.

MILANI, Carlos. O princípio da participação social na gestão de políticas públicas locais: uma análise de experiências latino-americanas e europeias Rev. Adm. Pública v.42 n.3 Rio de Janeiro, 2008. Disponível em: <http://www.scielo.br/>. Acesso: 06 de ago. 2016.

MOORE, J. ENAP- Editada pelo DASP em nov. de 1937 e publicada no Rio de Janeiro até 1959. Revista do Serviço Público. Brasília: 58 (2): 151-179 Abr/Jun 2007.

MOORE, M.H. A Conception of public Management. In: Teaching Public Management, 1-12 Boston, MA: Programa de política pública e Gestão para desenvolvimento de caso e curso. Boston University, 1984.

OLIVEIRA, Francisco de. Aproximações ao enigma: que quer dizer desenvolvimento local? In: SPINK, Peter et al. (Orgs.). Novos contornos da gestão local: conceitos em construção. São Paulo: Polis; Programa Gestão Pública e Cidadania/FGV-Eaesp, 2002.

PETERS, B, G. Politicians and Bureaucrats in the politics of policy-making. In: J-E-Lane, (ed.) bureaucracy and public Choice. Londres: sage, 1987.

PETERS, G. \& PIERRE, J. TOONEM, Theo. Introdução: O papel da Gestão Pública no Governo. In: Administração Pública: coletânea. Editora UNESP, ENAP, 2010.

PMI - PROJECT MANAGEMENT INSTITUTE. Um Guia do Conhecimento em Gerenciamento de Projetos (Guia PMBOK®). — Quinta edição. 2013.

PMI. Um Guia do Conhecimento em Gerenciamento de Projetos - Guia PMBOK $5^{\text {a }}$ Edição. EUA: Project Management Institute, 2013.

PORTER, M. E. What is Strategy? Harvard Business Review, v.74, n.6, p.61-78, 1996.

PORTER, Michael E. “O que é estratégia”. In: Porter, Micahel E. Competição. Rio de Janeiro: Campus/Elsevier, 1999. 
PORTER, Michael E. Estratégia Competitiva: técnicas para análise de industrias e da concorrência. Rio de Janeiro; Camus, 1986.

ROSENBLOOM, D.H. Understanding Management, Politics, and Law in the Public Sector. New York: McGraw-Hill, 1998

ROY, B. Vanderpooten, D, The European school of MCDA: Emergences, Basic Features and Current Works. Journal of Multicriteria Decision Analysis, v5, p.23-38, 1996.

SANTOS JUNIOR, Orlando Alves dos. Democracia e governo local: dilemas da reforma municipal no Brasil [recurso eletrônico] / Orlando Alves dos Santos Júnior. - 2. ed. - Rio de Janeiro: Letra Capital, 2015.

SEABRA, L.0. (2008) Metodologia para Gestão Estratégica do Transporte Público Urbano, baseada em Macroprocessos Estratégicos Organizacionais. Dissertação (Mestrado) UnB, Brasília.

SILVA, Valéria Cristina Pereira da Palmas, a última capital projetada do século XX: uma cidade em busca do tempo. São Paulo: Cultura Acadêmica, 2010.

VASCONCELOS, Eduardo Alcântara de. Transporte Urbano Espaço e Equidade: analise das políticas públicas. São Paulo: Annablume, 2001.

WEBER, Max. Economia e sociedade: fundamentos da sociologia compreensiva / Max Weber; tradução de Regis Barbosa e Karen Elsabe Barbosa; Revisão técnica de Gabriel Cohn - Brasília, DF: Editora Universidade de Brasília: São Paulo: Imprensa Oficial do Estado de São Paulo, 1999. 


\section{ROTEIRO DA ENTREVISTA JUNTO AO DECISOR (ESTRATÉGIA)}

\section{1- DADOS DE IDENTIFICAÇÃO DO ENTREVISTADO}

1.1- Órgão público:

1.2- Nome:

1.3- Cargo:

1.4- Tempo no cargo:

\section{2- ELEMENTOS DA ENTREVISTA}

2.1- apresentação dos objetivos da pesquisa;

2.2- descrição sucinta da metodologia;

2.2- $\quad$ apresentação dos Critérios de Avaliação, conforme (p.74-80).

\section{3- INSTRUÇÕES PARA COLETA DE DADOS}

Em seguida à apresentação dos Critérios de Avaliação, o pesquisador deve coletar os dados junto ao entrevistado (decisor) e preencher a matriz de preferência (abaixo), conforme o julgamento, critério com critério, sempre aos pares, do decisor. Para evitar possível retrabalho, dado a dificuldade de agenda do decisor (entrevistado), a sugestão é que o pesquisador utilize na entrevista, um laptop com o software M-MACBETH, resolvendo qualquer inconsistência.

Entre duas alternativas, o decisor deve escolher qual delas é mais atrativa e qual é a diferença de atratividade, isso num plano de escala semântica que possui a seguinte correspondência: Muito Forte (MF), Forte (F), Moderado (M), Fraco (Fr) e Muito Fraco (MF).

Modelo de questão: Sendo um critério "a" julgado mais importante (mais atrativo) que um critério "b", a diferença de atratividade entre "a" e "b" é MF, F, M, Fr ou MF?

\begin{tabular}{|c|l|l|l|l|l|}
\hline & Governança & Planejamento & Operação & $\begin{array}{c}\text { Participação } \\
\text { Social }\end{array}$ & $\begin{array}{c}\text { Meio } \\
\text { Ambiente }\end{array}$ \\
\hline Governança & & & & & \\
\hline Planejamento & & & & & \\
\hline $\begin{array}{c}\text { Operação } \\
\text { Participação } \\
\text { Social }\end{array}$ & & & & & \\
\hline Meio Ambiente & & & & & \\
\hline
\end{tabular}




\section{APÊNDICE B}

\section{QUESTÕES SUBMETIDAS AOS GESTORES DA PMU (EXECUÇÃO)}

\section{1- Questões sobre Governança:}

Dê sua opinião sobre como o Município tem enfatizado e executado os seguintes aspectos no tocante à Mobilidade Urbana.

1. O Município possui processo permanente e compartilhado de planejamento e tomada de decisões sobre mobilidade urbana.

Fortemente aplicado

Aplicado

Aplicação Moderada

$\bigcirc$ Pouco Aplicado

Nenhuma Aplicação

2. Participação em conjunto com outros entes federativos no desenvolvimento de políticas de mobilidade (Ex: União, Estado).

Fortemente aplicado

Aplicado

Aplicação Moderada

Pouco Aplicado

Nenhuma Aplicação

3. Atuação do Plano Diretor como instrumento de política de desenvolvimento para o ordenamento do espaço urbano.

Fortemente aplicado

Aplicado

Aplicação Moderada

$\bigcirc$ Pouco Aplicado

Nenhuma Aplicação 
4. Política de divulgação para promover a modalidade de deslocamento não motorizado.

Fortemente aplicado

$\bigcirc$ Aplicado

Aplicação Moderada

Pouco Aplicado

Nenhuma Aplicação

5. Inserção da mobilidade no programa municipal de governo.

Fortemente aplicado

Aplicado

Aplicação Moderada

$\bigcirc$ Pouco Aplicado

Nenhuma Aplicação

\section{2- Questões sobre Planejamento:}

Dê sua opinião sobre como o município tem enfatizado e executado os seguintes aspectos no tocante à Mobilidade Urbana.

1. Identificação dos meios financeiros e institucionais que assegurem a implantação e execução de programas com relação à área de mobilidade urbana.

Fortemente aplicado

Aplicado

Aplicação Moderada

Pouco Aplicado

Nenhuma Aplicação

2. Definição de metas de atendimento e universalização da oferta de transporte público coletivo.

Fortemente aplicado

$\bigcirc$ Aplicado

Aplicação Moderada

Pouco Aplicado

Nenhuma Aplicação 
3. Desenvolvimento de medidas de combate ao transporte ilegal de passageiros.

Fortemente aplicado

Aplicado

Aplicação Moderada

$\bigcirc$ Pouco Aplicado

Nenhuma Aplicação

4. Planejamento dos modos de integração do transporte público e destes com os privados e os não motorizados.

Fortemente aplicado

Aplicado

Aplicação Moderada

Pouco Aplicado

Nenhuma Aplicação

5. Programa de manutenção das vias municipais e suas sinalizações.

Fortemente aplicado

Aplicado

Aplicação Moderada

Pouco Aplicado

$\bigcirc$ Nenhuma Aplicação

\section{3- Questões sobre Operação:}

Dê sua opinião sobre como o município tem enfatizado e executado os seguintes aspectos no tocante à Mobilidade Urbana.

1. Existência de corpo de engenheiros em quantidade suficiente para atender as demandas do município.

Fortemente aplicado

Aplicado

Aplicação Moderada

$\bigcirc$ Pouco Aplicado

Nenhuma Aplicação 
2. Estabelecimento e publicidade de parâmetros de qualidade e quantidade na prestação dos serviços de transporte público coletivo.

Fortemente aplicado

Aplicado

Aplicação Moderada

Pouco Aplicado

Nenhuma Aplicação

3. Existência de capacitações regulares para o corpo técnico envolvido na área de mobilidade urbana.

Fortemente aplicado

Aplicado

Aplicação Moderada

Pouco Aplicado

Nenhuma Aplicação

4. Avaliações e correções regulares de problemas nas vias urbanas.

Fortemente aplicado

Aplicado

Aplicação Moderada

$\bigcirc$ Pouco Aplicado

Nenhuma Aplicação

5 Operacionalização de medidas educativas para redução de acidentes.

Fortemente aplicado

Aplicado

Aplicação Moderada

$\bigcirc$ Pouco Aplicado

Nenhuma Aplicação 


\section{4- Questões sobre Participação Social:}

Dê sua opinião sobre como o município tem enfatizado e executado os seguintes aspectos no tocante à Mobilidade Urbana.

1. Eficácia das ouvidorias nas instituições responsáveis pelo controle e avaliação da mobilidade.

Fortemente aplicado

Aplicado

Aplicação Moderada

$\bigcirc$ Pouco Aplicado

Nenhuma Aplicação

2. Atuação do Conselho de Mobilidade ou Conselho de Trânsito, formado por diversos setores da sociedade, na construção e aplicação dos planos de mobilidade.

Fortemente aplicado

Aplicado

Aplicação Moderada

Pouco Aplicado

Nenhuma Aplicação

3. Sistemática de comunicação e avaliação da satisfação dos cidadãos e usuários.

Fortemente aplicado

Aplicado

Aplicação Moderada

$\bigcirc$ Pouco Aplicado

Nenhuma Aplicação

4. Canais para recebimento de sugestões dos usuários e da população em geral.

Fortemente aplicado

Aplicado

Aplicação Moderada 

Pouco Aplicado
Nenhuma Aplicação

5. Integração do corpo técnico com a população na discussão das alternativas para os problemas de mobilidade urbana.

Fortemente aplicado

$\bigcirc$ Aplicado

Aplicação Moderada

Pouco Aplicado

Nenhuma Aplicação

\section{5- Perguntas sobre Meio Ambiente:}

Dê sua opinião sobre como o município tem enfatizado e executado os seguintes aspectos no tocante à Mobilidade Urbana.

1. Sistemática de análise dos impactos ambientais nas escolhas das medidas de mobilidade.

Fortemente aplicado

Aplicado

Aplicação Moderada

Pouco Aplicado

$\bigcirc$ Nenhuma Aplicação

2. Controle de poluentes no nível de trânsito e transporte
Fortemente aplicado
Aplicado
Aplicação Moderada
Pouco Aplicado
$\bigcirc$ Nenhuma Aplicação

3. Implantação de ciclovias como alternativa para reduzir índices de poluição. 

Fortemente aplicado
$\bigcirc$ Aplicado
$\bigcirc$ Aplicação Moderada
Pouco Aplicado
$\bigcirc$ Nenhuma Aplicação

\section{Campanhas de conscientização ambiental com relação à mobilidade.}

Fortemente aplicado

$\bigcirc$ Aplicado

Aplicação Moderada

Pouco Aplicado

Nenhuma Aplicação

5. Clareza na política de desenvolvimento sustentável da mobilidade urbana.

Fortemente aplicado

Aplicado

Aplicação Moderada

$\bigcirc$ Pouco Aplicado

Nenhuma Aplicação 